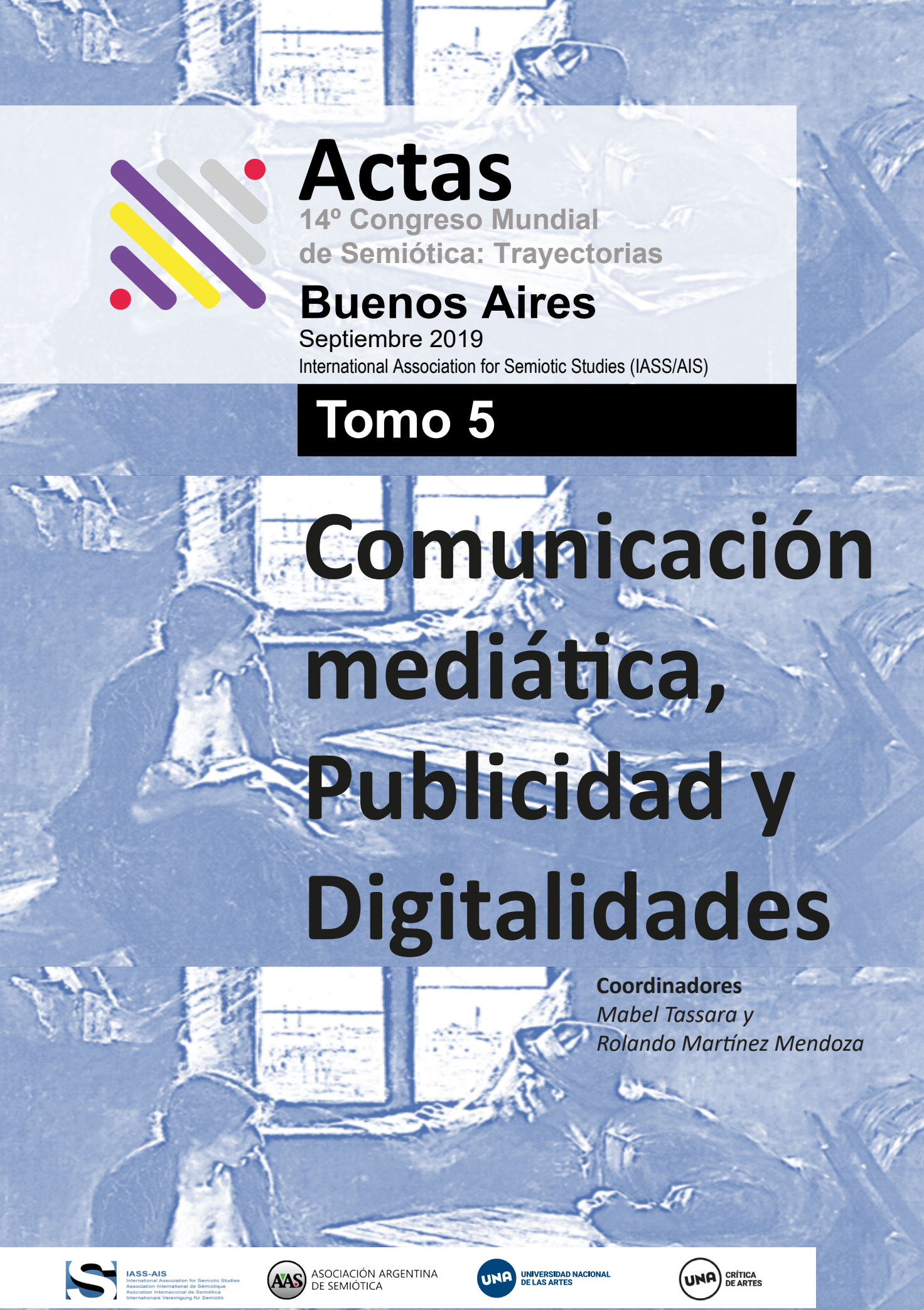

Proceedings of the 14th World Congress of the International Association for Semiotic Studies (IASSIAIS) 



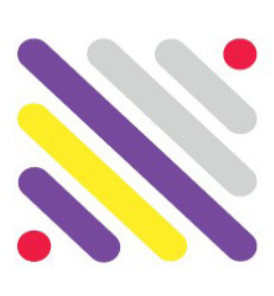

Actas

$14^{\circ}$ Congreso Mundial

de Semiótica: Trayectorias

\section{Buenos Aires}

Septiembre 2019

International Association for Semiotic Studies (IASS/AIS)

\section{Tomo 5}

\section{Comunicación mediática, publicidad y digitalidades}

Coordinadores

Mabel Tassara y

Rolando Martínez Mendoza 
Área Transdepartamental de Crítica de Artes

Actas Buenos Aires. 14을 Congreso Mundial de Semiótica : trayectorias : Proceedings of the 14th World Congress of the International Association for Semiotic Studies (IASS/AIS). Tomo 5. Comunicación mediática, publicidad y digitalidades / editado por Rolando Martínez Mendoza ; José Luis Petris ; prólogo de Mabel Tassara ; Rolando Martínez Mendoza. - 1a ed edición multilingüe. - Ciudad Autónoma de Buenos

Aires : Libros de Crítica. Área Transdepartamental de Crítica de Artes, 2020

Libro digital, PDF

Edición multilingüe: $\quad$ Alemán ; Español ; Francés; Inglés.

Archivo Digital: descarga y online

ISBN 978-987-47805-8-4

1. Semiología. 2. Semiótica. 3. Medios de Comunicación. I. Martínez Mendoza, Rolando, ed. II. Petris, José Luis, ed. III. Tassara, Mabel, prolog. IV. Título.

CDD 401.41

Actas Buenos Aires. 14 Congreso Mundial de Semiótica: Trayectorias. Trajectories. Trajectoires. Flugbahnen.

Asociación Argentina de Semiótica y Área Transdepartamental de Crítica de Artes de la Universidad Nacional de las Artes, Buenos Aires, Argentina.

Proceedings of the 14th World Congress of the International Association for Semiotic Studies (IASS/AIS)

Buenos Aires, 9 al 13 de septiembre de 2019.

\section{Tomo 5}

ISSN 2414-6862

e-ISBN de la obra completa: 978-987-47805-0-8

e-ISBN del Tomo 5: 978-987-47805-8-4

DOI: 10.24308/IASS-2019-5

(C) IASS Publications \& Libros de Crítica, noviembre 2020

Editores Generales José Luis Petris y Rolando Martínez Mendoza

Editores Marina Locatelli y Julián Tonelli

Diseño Andrea Moratti

Todos los derechos reservados. Ninguna parte de esta publicación debe ser reproducida, almacenada en un sistema de recuperación ni transmitida bajo ninguna forma ni por ningún medio, ya sea electrónico, mecánico, de fotocopiado, grabación o cualquier otro medio, sin el permiso de los editores.

Los editores rechazan cualquier responsabilidad en caso de declaraciones falsas o erróneas de los autores, contenido plagiado y uso no autorizado de material con derechos de autor. 


\section{Trayectorias}

Se elegió para la propuesta temática del congreso esta palabra: 'trayectorias', a causa de la extraordinaria pluralidad de sentidos que surge de sus usos contemporáneos.

El ejemplo más claro podemos encontrarlo en la trayectoria de definiciones de la misma palabra semiótica.

En este recorrido se despliegan las múltiples historias de su adopción como nombre de un campo de indagaciones analíticas y de publicaciones.

Sin embargo, el término Trayectorias, en plural, sugiere también que ese recorrido no es ni único ni lineal.

No oculta, en suma, la condición diversa de los caminos recorridos para la percepción de problemáticas intrínsecamente plurales y móviles.

A la vez, la variedad de trayectorias encuentra su razón en la multiplicidad de soportes mediáticos, dispositivos, medios y lenguajes que, en la contemporaneidad, se reclaman, se interpelan y se disputan tiempos y espacios.

Trayectorias, entonces, no se aplica aquí sólo a los desarrollos conceptuales de la disciplina semiótica sino, también, a los recorridos del cambiante conjunto de objetos (mediáticos, comunicacionales, de diseño, biológicos, arquitectónicos) en los que ella fija su mirada.

Las Trayectorias son, de este modo, las memorias, las materialidades y los compromisos que guían las definiciones, las escrituras y las búsquedas por los itinerarios del sentido.

Es por esto que se ha entendido que con el nombre Trayectorias se elegía un modo de reconocimiento de la condición insoslayable de despliegue y recomienzo que configura constantemente el quehacer de la investigación semiótica. 

Entre los días 9 y 13 de septiembre de 2019 se realizó en Buenos Aires, República Argentina, el $14^{\circ}$ Congreso Internacional de Semiótica. Fue organizado por la Asociación Argentina de Semiótica y la Universidad Nacional de las Artes de Buenos Aires (UNA) a través de su Área Transdepartamental de Crítica de Artes. El Congreso convocó a más de 700 expositores de 45 países. El intercambio en los Plenarios, las Mesas y los espacios de socialización fue de gran riqueza y humanamente imposible in situ de abarcar en su totalidad. Por este motivo es que la publicación de sus Actas se propone no sólo como registro del acontecimiento sino como una continuación y complemento del intercambio de ideas y trabajos semióticos que tuvo lugar, por primera vez, en América del Sur. La decisión de hacerlo en 8 tomos temáticos busca facilitar la profundización del diálogo en las áreas comunes de interés. 

Tomo 5

Comunicación mediática, publicidad y digitalidades 


\section{ÍNDICE}

Presentación.

Mabel Tassara y Rolando Martínez Mendoza

\section{SEMIÓTICAS DE LAS DIGITALIDADES}

La importancia de los estudios semióticos en el diseño de interfaces interactivas. Francisco V. C. Ficarra

The reading contract for the customization algorithm.

Gustavo Markier

The laws of semiotics and digitalization of culture:

the birth of new meanings. Marina Merkulova

Memória e esquecimento: ambivalências do digital entre a Wikileaks e o Facebook. Francisco Rui Cádima

Zonas de contacto y las nuevas formas de circulación: trayectorias discursivas y participación en línea.

Eduardo Ruedell y Viviane Borelli 55

\section{DIGITALIDAD Y ARTES}

Semiótica das interações no audiovisual: produção de sentidos no clipe interativo "Saturn Barz".

Bárbara Heliadora Cavalcante Fontenelle y Murilo Scoz

Ari Folman's promises of technological mediation in The Congress. Cassia Cassitas

A transmídia como semiosfera para a construção estética. Gisele Frederico

Configuraciones discursivas de la crítica cinematográfica en youtube. Laura Andrea Iribarren 
Folklore digital, prosumidores y creepypasta.

Sandra Sánchez

\section{NUEVAS MEDIATIZACIONES DEL ESPACIO URBANO}

Semiótica narrativa en el discurso publicitario contemporáneo: análisis de la landing page de "Manantiales" del Grupo Edisur. Belén Angelelli y Natalia Desirée Vaccaro

Smarthphones y auriculares para inscribir la ciudad como escenografía. Mónica Berman

Reflections about new perceptions on space and time: the use of mobile phone in the Metro de Santiago, Chile. Catalina Largo González

\section{SEMIÓTICA DE LA/S MARCA/S}

Semiótica aplicada: campanha publicitária Journey, com Angelina Jolie, sob o espectro da teoria peirceana. Carolina Boari Caraciola 161

Modalidades de inserción de emergentes culturales en la comunicación de las marcas. Claudio Centocchi

La construcción del destinatario en la Marca País Argentina. Daniela Fiorini y Paula Socolovsky

Semiótica aplicada: análise de peças da marca Gatorade à luz da teoria peirceana. Gabriel Moni de Souza, Heder SeitiOno y Maria Clotilde Perez

\section{RECURRENCIAS Y NOVEDADES EN ESPACIOS DE LA PUBLICIDAD}

Trajectories and meanings in specialty coffee packaging: a semiotic exploration of the Brazilian market. Maria Collier de Mendonça, Flavia Cardoso y Richard Perassi

Estrategias, transacciones y símbolos en la publicidad electoral audiovisual. María Ernestina Morales 
Racismo y clasismo en la publicidad mexicana.

Carl Winston Jones

Adverfilms y fenómenos de retoma: una aproximación sociosemiótica a la discursividad publicitaria en plataformas interactivas. Lorena Steinberg

Índice general de las Actas 261 


\section{Presentación}

DOI: 10.24308/IASS-2019-5-001

Hace casi sesenta años que la semiótica se interesa por la relación entre la producción social de sentido y los medios de comunicación, a partir de la consideración de la diversidad de sus lenguajes y los dispositivos en que ellos se insertan.

Los trabajos pioneros de Christian Metz sobre el cine, Roland Barthes y Georges Péninou sobre la publicidad, Umberto Eco sobre la televisión y el comic son algunos ejemplos de esta temprana y fecunda atención a la producción discursiva propia de la cultura de masas, así como a la multiplicidad constitutiva de origen que encara el proyecto semiótico. Preocupación que, en lo local, se hacía presente a principios de la década de 1970 en la revista Lenguajes, uno de los hitos fundantes de la semiótica argentina, en la que encontramos aportes inaugurales a esos estudios, como los de Oscar Steimberg, Oscar Traversa o Eliseo Verón.

Las ponencias del Tomo 5, "Comunicación mediática, publicidad y digitalidades", se inscriben en esta trayectoria, al privilegiar el estudio de objetos producidos en el espacio de los medios masivos de comunicación, al par que se abren a la discusión sobre la irrupción en esos territorios de las denominadas nuevas tecnologías. Ellas resaltan el interés de contemplar las especificidades de cada dispositivo mediático con sus lenguajes y sus particulares formas de proponer y generar vínculos enunciativos diferenciados entre la emisión y la recepción. Se pone aquí de relieve, entre otras cosas, la importancia conceptual y metodológica que adquiere la observación analítica de la tensión siempre existente entre la producción y su recepción, cuando hace presentes las estrategias operativas y las expectativas subyacentes en la primera y las presiones de cultura y época en la segunda, quedando manifiesta la dimensión política asociada a ambas. 
Las tópicas mencionadas ya encuentran desarrollo en "Semióticas de las digitalidades", la sección que abre el Tomo. Por una parte, se focalizan en ella algunos de los múltiples y diferentes procesos significantes disparados por los nuevos medios digitales; por la otra, se pone en evidencia la exigencia de formular disciplinas semióticas específicas (refiriendo el término "disciplina" a un conjunto de teorías y metodologías específicas al caso) y entablar una discusión acerca de la pertinencia de nociones y herramientas metodológicas potenciales para el análisis de los productos de cada nuevo dispositivo, contemplados más allá de la tecnología que los hace posibles.

El abordaje de nuevos objetos de la comunicación mediática, no como productos de nuevas tecnologías sino en tanto nuevas producciones discursivas que habilitan, en el decir de Eliseo Verón, "saltos de escala" en la trama de la semiosis social es el eje articulador de las dos secciones siguientes: "Digitalidad y artes" y "Nuevas mediatizaciones del espacio urbano".

En el conjunto de artículos que componen "Digitalidad y artes" se encuentran observaciones en torno de la incidencia de las nuevas mediatizaciones, la transmediación, la implementación de técnicas digitales y las prácticas interactivas en el espacio de las artes, donde se ven afectados tanto las obras como los lenguajes artísticos implicados y el territorio de la crítica. Surge, asimismo, la convivencia y la interacción de formas provenientes de orígenes diversos: viejos lenguajes artísticos, nuevos universos del campo de las artes, discursividades provenientes de otras áreas de lo social y lo cultural.

Se destaca en la sección que sigue la repercusión de los procesos de mediatización en la configuración del espacio urbano y en la reflexión que se entabla en su torno. Las trayectorias por la ciudad a través de y con los dispositivos móviles y los relatos acerca de la modernización arquitectónica del espacio urbano tradicional son ejes 
para el abordaje de los cambios sucedidos en la percepción de lo urbano, como marco escenográfico y como construcción significante del habitar y transitar de los ciudadanos.

Las discursividades de la publicidad no son ajenas a las consecuencias de los nuevos procesos de mediatización, pues necesitan apelar a lo socialmente establecido y, a la vez, se ven compelidas a mutar y capturar las pequeñas diferencias, inscribiéndose dinámicamente en la constante recreación de posibilidades y recursos de los diversos lenguajes, medios, géneros y estilos. Una "Semiótica de la/s mar$\mathrm{ca} / \mathrm{s}$ " puede así pensar la complejidad del juego de identificaciones de los consumidores con las imágenes de los productores de bienes y servicios. Los artículos de esta sección buscan dar cuenta de esa interrelación, que hoy adquiere una multidireccionalidad inédita.

En tanto la publicidad no es ajena a las transformaciones generadas en el conjunto de las tramas del sentido, las ponencias de "Recurrencias y novedades en espacios de la publicidad" hacen visible la retoma en el área de las observaciones sobre continuidades, quiebras, desplazamientos y transmutaciones anteriormente citadas respecto de otros campos. Además del interés que cobran las huellas de la agenda cultural en esas producciones.

En síntesis creemos que, frente a la siempre renovada fascinación que rodea la emergencia de novedades, en particular, las tecnológicas, este Tomo 5 de las Actas del 14을 Congreso Mundial de Semiótica se constituye en una reflexiva toma de distancia sobre las relaciones entre la mediatización de prácticas existentes, la resignificación de espacios y los nuevos comportamientos de apropiación. A partir de su especificidad semiótica y la formulación de interrogantes acerca de posibles postulados teórico-metodológicos, los tratamientos de los temas evitan la tentación frecuente de considerar cada fenómeno como confirmación de construcciones teóricas y disciplinares 
previas, revalorizando una discusión de época, que siempre corre el riesgo de frivolizarse o resultar tangencial a sus objetos.

Mabel Tassara y Rolando Martínez Mendoza 


\section{SEMIÓTICAS DE LAS DIGITALIDADES}





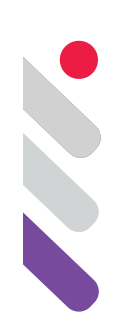

\section{La importancia de los estudios semióticos en el diseño de interfaces interactivas}

\section{Introducción}

Las interfaces interactivas se han ido desarrollando desde la aparición de los primeros sistemas en donde el píxel en las pantallas de las computadoras u ordenadores superaban las letras para comenzar a trazar líneas, figuras, etc., en formato 2D, y posteriormente emulando el 3D (Hampshire y Stephenson 2006; Mitchell y McCullough, 1995). Desde ese entonces la noción de metáfora, por ejemplo, ha tenido un rol muy importante, para acercar a millones de potenciales usuarios a las computadoras u ordenadores. Una noción que encuentra su intersección entre la lingüística, la semiótica y el diseño de interfaces (Le-Guern 1990; Apple 1992).

En el proceso de elaboración del diseño de las interfaces desde los primeros sistemas operativos para ordenadores personales de Apple, IBM, etc., el rol de la semiótica ha sido fundamental. Sus conceptos básicos relacionados con denotación, connotación, isotopías, ambigüedad, redundancia, por citar algunos ejemplos, han constituido puntos cardinales para el diseño de los iconos (Nöth 1995; Cipolla-Ficarra 1996). Unos componían la metáfora de la interfaz de los principales sistemas operativos, con difusión mundial y que han permitido facilitar el uso del sistema operativo Windows, por ejemplo.

En los '90, con la democratización de Internet, y el auge de los sistemas hipertextuales, multimediales, e hipermediales se produce una expansión de la necesidad de incorporar a la semiótica ya no solo en la fase de elaboración de los sistemas interactivos, sino también en la evaluación y corrección de eventuales errores por parte de usuarios y especialistas, antes de la comercialización masiva e internacional de los sistemas de multimedia en soporte CD, DVD, online, etc. 
En ese contexto, se hace necesario de dividir la noción de diseño interactivo en varias categorías, tales como presentación, contenido, navegación, estructura, navegación, entre otras (Cipolla-Ficarra y otros 2018). Esa capacidad de análisis y desglose de los componentes del diseño/evaluación de una interfaz, no solo ha permitido revalorizar esta área del saber (la semiótica) en el ámbito informático y de la ingeniería del software, sino que también, ha establecido las bases para generar nuevos profesionales, orientados hacia una evaluación heurística de los sistemas interactivos, sin recurrir a laboratorios, equipamientos, etc. Paralelamente, se ha fomentado la noción de calidad en comunicación interactiva. Es decir, la comunicabilidad (Cipolla-Ficarra y otros 2018). Una comunicabilidad en donde el rol de la semiótica y la lingüística son prioritarios, desde el diseño de las interfaces de los nuevos dispositivos interactivos móviles, en función de las expectativas de los potenciales usuarios pertenecientes a la generación $Z$.

\section{La heurística y la comunicabilidad en las interfaces}

El objetivo de la evaluación heurística de un sistema interactivo actual es encontrar los problemas de diseño de la interfaz para mejorar la comunicabilidad y su uso. Para alcanzar dicha meta diversos evaluadores examinan la interfaz y juzgan su conformidad en función de un conjunto de principios de comunicabilidad y usabilidad denominados también criterios o atributos heurísticos. La noción "criterio heurístico" proviene del inglés heuristic criteria. En el presente trabajo se utiliza el término atributo en vez de criterio pero destacándose la relación con la calidad.

Históricamente, algunos de estos principios heurísticos han sido propuestos con el uso de un sistema interactivo (Nielsen y Mack 1994). Es decir, la evaluación heurística es una inspección sistemática de la usabilidad de una interfaz de usuario. Además, Nielsen sostiene que la usabilidad es una propiedad de la interfaz de usuario, que posee múltiples componentes y está asociada con cinco atributos tradicionales (Nielsen 1990):

1. Aprendizaje: El sistema debería ser fácil de aprender para que el usuario pueda trabajar con el mismo inmediatamente.

2. Eficiencia: El sistema debería ser eficiente al usarlo para que una vez que el usuario lo aprenda, obtenga un alto nivel de productividad.

3. Errores: El sistema debería tener un bajo porcentaje de errores para que los usuarios realicen pocos errores durante el uso del mismo.

4. Mnemotécnico: El sistema debería ser fácil de recordar para que el usuario casual pueda volver al sistema, después de algún período en que no lo haya utilizado, sin necesidad de repetir nuevamente el aprendizaje.

5. Satisfacción: El sistema debería ser ameno en su uso, para que los usuarios estén subjetivamente satisfechos cuando lo usen. 
Entre los atributos más importantes podemos citar el uso de un dialogo natural y simple, de un mismo lenguaje del usuario, mensajes de ayuda, etc. Estos atributos fueron denominados como "heurísticos" (Nielsen y Mack 1994). Los atributos heurísticos establecieron las bases para elaborar una metodología de análisis de los sistemas multimedia: MEHEM (Methodology for Heuristic Evaluation in Multimedia), con sus correspondientes métricas para la comunicación MECEM (Metrics for the Communications Evaluation in Multimedia), y que posteriormente evolucionaría hacia la comunicabilidad (Cipolla-Ficarra y otros 2018). Los análisis son realizados por un experto en comunicabilidad. La definición de los atributos responde a la realización y evaluación de aplicaciones interactivas, a través de uno o varios modelos del diseño interactivo. Algunos de los primeros modelos para el diseño de los sistemas de hipertexto, multimedia e hipermedia, se puede resumir de la siguiente manera:

- El modelo Garg está orientado a la creación de documentos multimediales. Permite varios grados de abstracción, por lo tanto, es posible hacer una investigación más detallada de las partes que componen el documento.

- El modelo Tompa emplea hipergrafos dirigidos y etiquetados para el diseño de redes hipertextuales. Tiene un conjunto finito de nodos y de aristas, y además es posible diferenciar entre el contenido y la estructura.

- El modelo Statechart es una extensión de los hipergrafos. Permite representar la estructura y la semántica de navegación de los sistemas hipertextuales.

- El modelo Trellis utiliza lad redes de Petri para representar la semántica de navegación en el sistema de hipertexto.

- El modelo HB1 es un sistema de gestión de bases de datos semánticas.

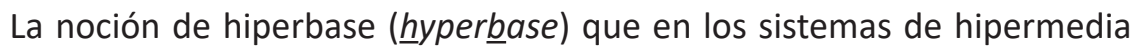
hace referencia a la base de datos proviene de este modelo.

- El modelo MacWeb está basado en los conceptos de la orientación a objetos, en que los tipos (clases) son utilizados para comprender el hipertexto, y las instancias para mantener la información del hipertexto (contenido).

- El modelo RMM (Relationship Management Methodology) recurre al modelo de los datos RMDM (Relationship Management Data Model) para el diseño de la información y los enlaces dentro del sistema hipermedia. El RMDM se basa en dos primitivas de dominio como son "entidad" y "relaciones" entre las entidades, y cinco primitivas de acceso a los datos: enlaces unidireccionales, enlaces bidireccionales, índices, enlaces guiados y colección.

Todos estos modelos, junto a otros similares han sido desarrollados por 
matemáticos, físicos, ingenieros nucleares, industriales, etc. Es decir, modelos generados ad infinitum dentro de las ciencias factuales. Los profesionales de las ciencias sociales prácticamente no participaban en el desarrollo de los mismos. Por consiguiente, se fomentaba un verticalismo unidireccional en el contexto de las ciencias, contradiciendo los principios epistemológicos de las mismas. Esta es la razón principal por la cual en el contexto del diseño y la programación de sistemas interactivos, se ha verificado con el transcurso de las décadas, que todos los modelos existentes, no hayan sido capaces de generar un lenguaje propio y común, entre los profesionales del sector. Tan solo, desde la ingeniería del software había algunos autores que reclamaban la presencia de psicólogos, sociólogos, pedagogos, entre otros, para incrementar calidad del software, teniendo en cuenta al usuario final de los sistemas interactivos (Basili y Musa 1991).

Sin embargo, en cada uno de los modelos se puede constatar como implícitamente hay algunas nociones básicas provenientes de la semiótica y la lingüística, aunque hagan referencia a un marco informático. Modelos que al inicio se están refiriendo a textos o documentos, pero que luego incluirían imágenes estáticas (fotos, mapas, etc.), música, sonidos, etc., hasta llegar a las imágenes dinámicas (vídeo, animaciones por computadora, etc.). Es decir, una convergencia de los medios estáticos y dinámicos. Es la evolución del hipertexto hasta la hipermedia, pasando por la multimedia.

Ahora bien, los modelos se referían a las bases de datos, la navegación del usuario ante las diversas modalidades para la fruición de la información, la visualización parcial o completa de los contenidos, la metáfora empleada en la interfaz y la distribución de los elementos en las pantallas, etc. Cada uno de estos aspectos relacionados con el diseño interactivo y la programación del sistema podían ser agrupadas en categorías de diseño. Por ende, los atributos cualitativos están interrelacionados con las categorías. Unas categorías que han ido progresando con el avance de las TICs (tecnologías de la información y la comunicación), especialmente, con la telefonía móvil multimedia. Algunos ejemplos de los primeros sistemas interactivos pueden consultarse en el anexo online: www.pirateando.net/IASS-AIS-ARG-2019-A.

\section{Primeros atributos cualitativos basados en la semiótica y la lingüística}

Los atributos heurísticos, que deben ser considerados en la evaluación de una interfaz de usuario en los sistemas interactivos, constituyen un conjunto de "subatributos" de la comunicabilidad. Algunos de ellos, basados en la semiótica y la lingüística son:

\subsection{Transparencia del significado}

Latransparencia del significadoanaliza el uso de términos (principalmente), 
imágenes y sonidos dentro de la interfaz que no producen ambigüedades entre el plano del contenido y el plano de la expresión. Los elementos que componen la interfaz están interrelacionados cumpliendo una función de anclaje o reforzamiento del significado. Los elementos hacen referencia a los términos (considerados como una cadena de caracteres), imágenes (estáticas o dinámicas) y sonidos. En una interfaz histórica de un sistema multimedia offline, de la figura 1 se observa como las componentes de la interfaz con sus correspondientes rótulos refuerzan el significado de "artista".

La noción de signo hace referencia a los estudios de Saussure. Ahora bien, si el nexo que une el significado y el significante es arbitrario, entonces el signo es arbitrario, es decir, depende de un conjunto de reglas preestablecidas a lo largo del tiempo, como es el caso de una lengua (Saussure 1982; Eco 1991). Pero a la imagen acústica definida por Saussure se le debe sumar la imagen gramatical en el ámbito del significante, tal como sostiene Hjelmslev (Nöth 1995). Esta corrección ha permitido superar la idea de significante como mera secuencia fónica (expresión). Sin embargo, en la división en dos planos de Hjemslev como son la expresión (significante) y el contenido (significado) se observa que también existe entre sus componentes una relación bidireccional, al igual que en la noción de signo saussuriano . Sin entrar en el binomio metodológico forma/ sustancia que aplica Hjelmslev, en la presente investigación se ha centrado en la transparencia del concepto o significado saussuriano o del contenido de hjemlsleviano para evitar la ambigüedad. Un contenido ambiguo es aquel que fuera de todo contexto es posible asignar dos o más interpretaciones.

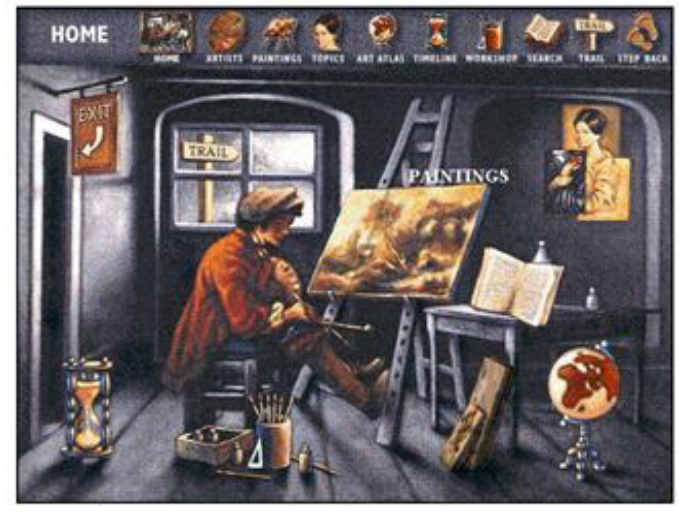

Fig. 1: Interfaz clásica de un sistema multimedia off-line en donde el texto refuerza los componentes de la imagen, reduciendo la ambigüedad.

El triángulo de Baldinger (Nöth 1995) sirve para observar un caso de ambigüedad con el término "piano" en varios idiomas, que dependiendo del contexto podría afectar la comunicabilidad. 


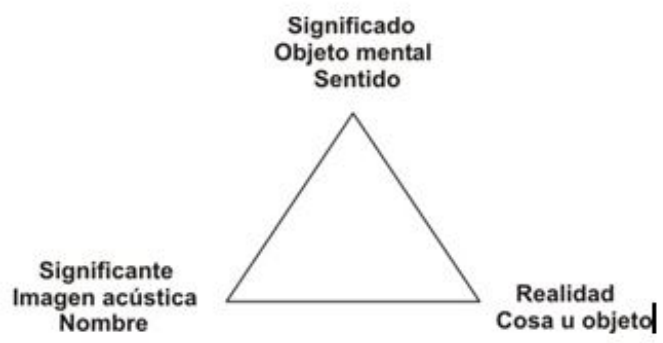

Fig. 2: Relación triádica entre significado, significante y objeto.

La escritura del término "piano", como la pronunciación en español, francés, inglés e italiano es idéntica. Además, se hace referencia al mismo instrumento musical. Pero en el caso del italiano, la relación entre el significante y el significado es más "rica", es decir, además del instrumento musical connota varios "elementos" de la realidad:

1. Andar o caminar lentamente.

2. Plan de actividades o de trabajo.

3. Plano de un edificio o de una comarca.

4. Planta o piso de un edificio.

5. Superficie llana.

6. Susurrar.

Dicho fenómeno de connotaciones o de riqueza de contenido está en relación con la noción de semiosis ilimitada de Pierce (Eco 1991). Saussure y Hjelmeslev consideran al signo como biplánico, pero con Pierce se establece una tríada entre un objeto (real o imaginario), la representación (expresión material, como es una palabra) y el interpretante (contenido). Es la interrelación interpretante y representación en donde se produce la semiosis ilimitada. La semiosis ilimitada es un acontecimiento normal en la evolución de una lengua (Eco 1991; Nöth 1995). Este el motivo por el cual en un sistema multimedia cuyo objetivo es el aprendizaje de varios idiomas sino se insertan imágenes del objeto al cual se está refiriendo, un término de forma aislada puede dar lugar a confusiones en el momento de la interacción del usuario. La imagen en ese caso cumple la función de anclaje del sentido. Además, la ambigüedad del significado en los sistemas interactivos, sean inteligentes o no, se presenta ante el usuario como una disyunción entre dos o más interpretaciones distintas y se carece de una orientación, especialmente, entre los usuarios adultos y la generación Z, ante los iconos presentes en las interfaces de la telefonía móvil multimedia, por ejemplo. Es importante señalar que la ambigüedad es básicamente un problema de significado más que de significante.

En referencia a la riqueza del contenido se observan dos situaciones: una positiva y otra negativa. Por un lado, puede complicar la "descodificación" del mensaje dada la abundancia de datos delante del usuario, y por el otro lado, 
facilita la descodificación al reducir el número de interpretaciones. A pesar de ello el usuario se encuentra ante varias interpretaciones y no sabe que sentido escoger. El contexto brindado por una metáfora natural facilita la tarea de escoger la interpretación más acorde entre las diversas alternativas que han sido presentadas.

Finalmente, relacionada con la ambigüedad se encuentran estas dos nociones: Vaguedad e indeterminación:

- La vaguedad. Un término es vago cuando sus límites de designación son imprecisos. En la siguiente definición del lenguaje " $C$ " en la Enciclopedia de la ciencia la expresión: "es un lenguaje de programación más extendido", el término "extendido" por sí solo no establece con exactitud el motivo de la extensión como pueden ser los siguientes factores: por la facilidad de uso, la

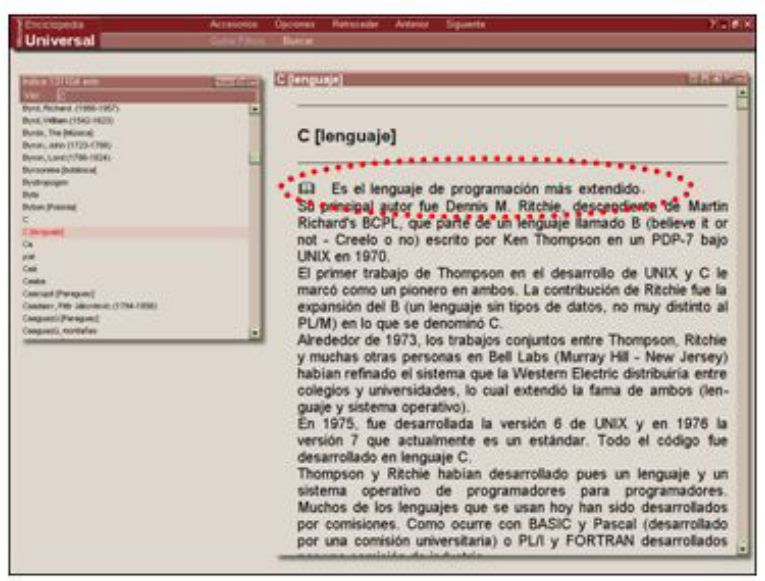
compatibilidad con los otros lenguajes de programación, la antigüedad, etc.

Fig. 3: Ejemplo de un término "vago".

En tales circunstancias siempre existen realidades que pueden ser denotadas tanto por el término como por signos vecinos en el sistema. La vaguedad es un fenómeno de designación, no de significación. Este fenómeno tiene su origen en los límites inexactos que poseen la clase designativa de los signos de un idioma o una lengua natural. Los significados dentro de la misma se establecen a partir de oposiciones de conceptos. Los signos de las lenguas naturales conocen un alto grado de vaguedad. El lenguaje científico que pretende ser preciso y exacto debe evitarla en lo posible. Esta precisión es un objetivo a cumplir y que tiene sus inconvenientes en conseguirlo ya que en las definiciones del lenguaje científico se utilizan términos del lenguaje natural.

- La indeterminación es la falta o la pobreza de la información. El usuario desea saber más datos de los que se transmiten en el mensaje. En la indeterminación el significado siempre es único no hay duplicidad o multiplicidad significativa. Es un recurso empleado para motivar el avance en un sistema de la 
enseñanza asistida por computadora u ordenador, en donde los contenidos se le presentan al estudiante de manera fraccionada y gradual.

\subsection{Isomorfismo}

El isomorfismo permite establecer en los sistemas multimedia un conjunto de rasgos formales constantes entre las componentes de las distintas categorías del diseño como son: presentación, contenido, estructura, navegación o dinamismo, etc. Es decir, determina la misma forma de la presentación (particularmente la topología en la distribución de los elementos en la pantalla); el comportamiento de los medios dinámicos, y la organización de los contenidos en las diversas maneras de estructurar la información. Por ejemplo, como se mantiene el mismo sitio el conjunto de teclas para la navegación dentro de la pantalla, ya sea en aquellas pantallas que forman parte de un enlace guiado o una colección secuencial (por ejemplo, el visionado de fotografías o pinturas, en un álbum digital). A continuación se presenta un ejemplo clásico en que hay isomorfismo entre varias categorías del diseño: el contenido, la presentación, la navegación y la estructura, por ejemplo.

Los grandes artistas ${ }^{1}$ (The Great Artist) es un sistema interactivo offline, en donde se puede comprobar fácilmente la existencia del isomorfismo entre la entidad "pintores" y "pinturas" de Leonardo da Vinci (figuras 4 y 5). Al compararse ambas pantallas se observa que existe una presentación similar en la ubicación de las teclas para acceder a otros componentes del sistema (elipses en la parte superior de ambas pantallas), el color del fondo, la tipografía, etc. se mantiene una misma navegación bidireccional en ambas entidades (manos en los ángulos inferiores derecho e izquierdo), una estructura idéntica en referencia a las imágenes y los textos estáticos. En el contenido textual se puede observar que en ambos casos se comienza por la palabra "Leonardo".

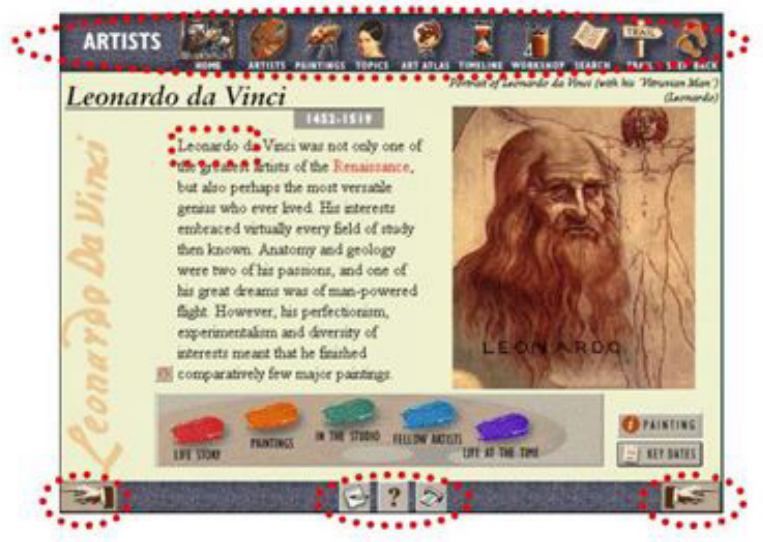

Fig. 4: Entidad "pintor" Leonardo da Vinci.

\footnotetext{
${ }^{1}$ The Great Artist CD-ROM. 1994. London: Marshall Cavendish \& Attica Cybernetics.
} 


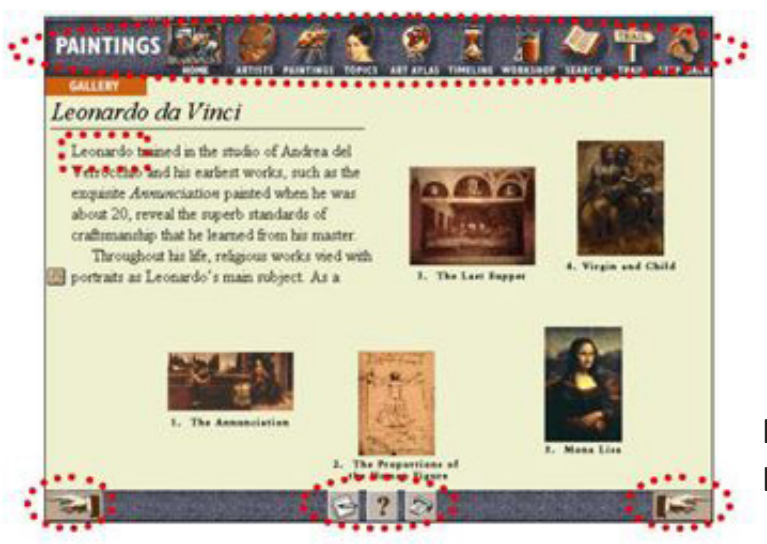

Fig. 5: Entidad "pinturas" Leonardo da Vinci.

El isomorfismo permite disminuir la ambigüedad del usuario ante el sistema, facilitando el aprendizaje del funcionamiento cuando se carece de experiencia previa en la navegación de sistemas interactivos. Es un atributo de calidad difícil de encontrar en las interfaces de la telefonía de última generación, ya que los autores de cada aplicación no siguen un modelo determinado por la comunicabilidad. Además, son productos en donde los manuales de usuario son prácticamente inexistentes y los usuarios no pertenecientes a la generación $Z$, deben recurrir a la experimentación propia o a la solicitud de ayuda de usuarios expertos. El isomorfismo, junto a la naturalidad de la metáfora, en la interfaz favorece la motivación para la fruición de contenidos multimediales.

\subsection{Naturalidad de la metáfora}

La naturalidad de la metáfora evalúa la capacidad de comprensión del usuario sobre las imágenes que conforman la estructura de la pantalla. Una imagen es natural cuando por sí sola tiende a trasmitir un único significado. El texto o el sonido que compone una pantalla de un sistema multimedia no deberían ser empleados para explicar el significado de las imágenes. La función de los mismos debe servir para reforzar el significado unívoco de la pantalla y no de algunos de sus componentes. La naturalidad de la imagen está en relación directa con la representación por simulación del mundo real. Hay tres maneras de representar el mundo real en la pantalla de una computadora, tablet $P C$, smartphone, watchphone, entre otros:

- Abstracción o artística,

- simulación de la realidad (naturalidad), y

- combinación de la abstracción y simulación.

La selección de estas modalidades depende del objetivo de la aplicación. Sin entrar en los detalles psicológicos de los modelos mentales, la emulación de la realidad existe en los modelos artísticos o abstractos. En los modelos 
abstractos el grado de realismo es menor e impide un correcto proceso de interacción y la única finalidad de dichos modelos es atraer momentáneamente la atención del usuario. En una representación por simulación el grado de realismo es mayor. Estos conceptos se pueden observar en el gráfico de la figura 6. La línea de la presentación por simulación del mundo real tiene una leve curvatura en comparación con la presentación por emulación. En ésta última se señala el "ruido" en la interacción con el mundo real.

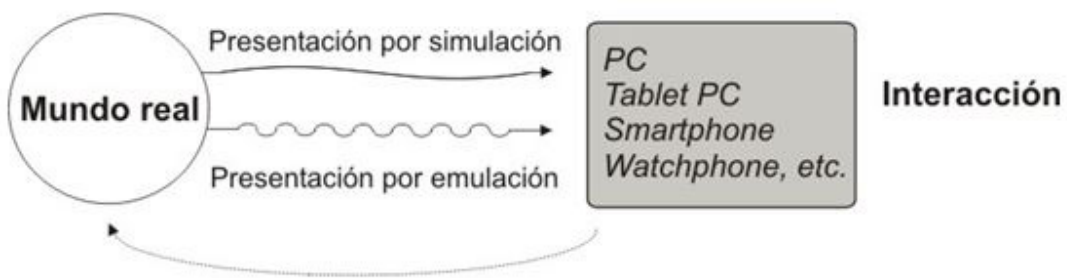

Retroalimentación

Fig. 6: Dos maneras diferentes de presentar el mundo real en las pantallas

La línea de la presentación por simulación del mundo real tiene una leve curvatura en comparación con la presentación por emulación. En ésta última se señala el "ruido" en la interacción con el mundo real. El diseñador de una interfaz tiene como función representar la realidad. El problema está en que dicha representación sea una emulación de la realidad. En ese caso, el nivel de la abstracción es alto y sus componentes son ambiguos llegando incluso a perjudicar la comunicabilidad. Uno de los clásicos ejemplos es el uso de recursos iconográficos para la navegación en los smartphones de última generación, los cuales en algunos casos pueden ser comunes para los adultos y no para los jóvenes, y viceversa. Esa dificultad se debe a que son objetos históricos de la cotidianidad. Por ejemplo, el uso del despertador a cuerda o el reloj de arena, para indicar el transcurso del tiempo. Una manera de erradicar la ambigüedad en la presentación de las imágenes es recurrir a la incorporación del texto, por ejemplo. Por lo tanto, el uso de las metáforas dentro del proceso de comunicación usuario-computadora u ordenador debe tender más a la simulación de la realidad que a la emulación. Además, debe tener presente el contexto espacio-temporal de la iconografía utilizada.

Las metáforas son modelos provenientes de ciertos sistemas del entorno real o abstracto del ser humano. Ellas tienen la finalidad de ayudar al usuario a aprender. Este objetivo permite acercar el modelo conceptual del sistema al modelo mental del usuario, como se ha constatado en los primeros sistemas educativos a distancia, en la UOC (Universidad Oberta de Cataluña), tal como se 
observa en las figuras 7, 8, 9 y 10. La metáfora puede hacer más fácil el aprendizaje y el uso del sistema porque permite a los usuarios actuar según las maneras que ya les son familiares (Laurel 1990). Esta comprensión del sistema se basa en el área visual (presentación) y de la interacción (dinámico). La naturalidad de la metáfora permite al usuario navegar hacia los medios dinámicos que simulan la realidad y disminuye considerablemente la ambigüedad de la presentación. Además, el presente atributo de calidad respeta el principio del diseño gráfico de interfaces (WYSIWYG - What You See Is What You Get): "Aquello que Ud. ve es lo que puede hacer" (Apple 1992). Un principio que actualmente, ha desaparecido en un sinfín de interfaces elaboradas para los sistemas en los últimos modelos de telefonía móvil multimedia.

En el ámbito de la presentación, la metáfora define el aspecto visual de la interfaz, determinando cuales objetos visuales deben ser incorporados, y cómo los objetos deben ser distribuidos sobre la pantalla, desde la perspectiva de la topología. Algunos buenos ejemplos de metáforas en sistemas interactivos off-line han sido: el libro, el escritorio y el correo electrónico. En el caso de la metáfora del escritorio empleada por Apple Computer fue un cambio positivo para la interfaz de los sistemas operativos, siendo los ordenadores Macintosh los primeros en incorporarla (Apple 1992).

En referencia a la metáfora del correo electrónico y dentro del ámbito del educativo se realizó para la UOC un sistema multimedia, en tiempo record y con resultados excelentes (Cipolla-Ficarra 1996). El objetivo era explicar la aplicación de conexión a Internet denominado FirstClass. O sea, lograr la comunicación entre aquellos usuarios que jamás han tenido experiencia previa con ordenadores o computadoras, desde sus hogares o puestos laborales hacia la UOC. Para tal fin, en el momento del diseño se recurrió a la metáfora de correos de la vida real. Elementos como el personaje escribiendo una carta delante de la Oficina Central de Correos, o el buzón cumplieron la función de refuerzo del mensaje.

Una buena metáfora es aquella en donde se refleja fielmente las acciones del usuario en el momento de la navegación. En la aplicación FirstClass de las figuras 8 y 9 el personaje animado que representa a la profesora salta de alegría si el usuario supera el examen de los conocimientos adquiridos en la autoevaluación, en caso contrario hace un gesto de desaprobación. 


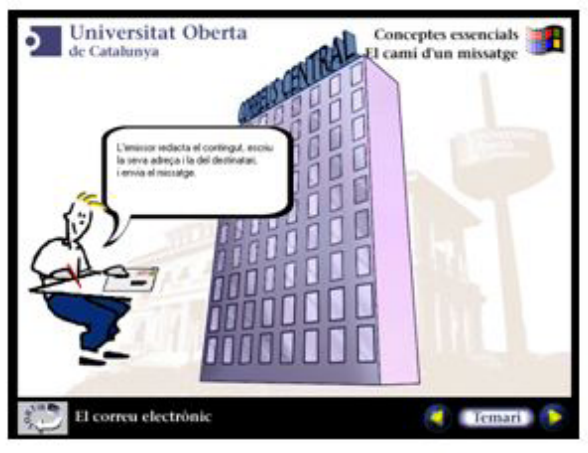

Fig. 7: Acciones relacionadas con la metáfora en la aplicación FirstClass

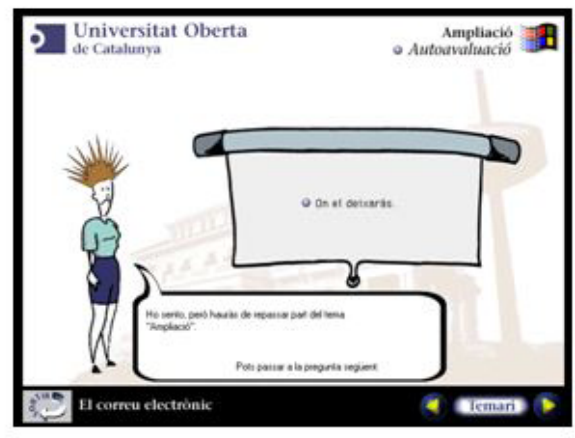

Fig. 9: Autoevaluación con resultados negativos.

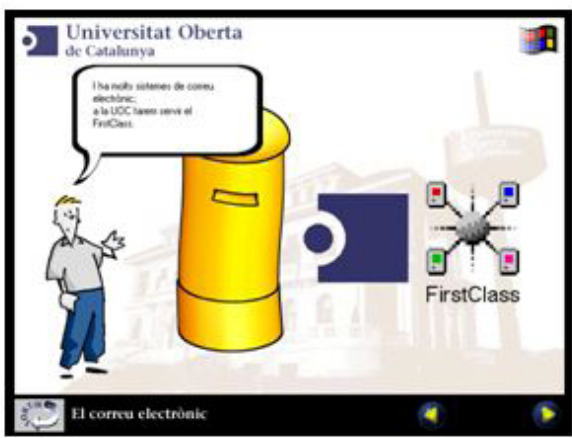

Fig. 8: Uso del texto para erradicar la polisemía del símbolo en la interfaz de la aplicación FirstClass

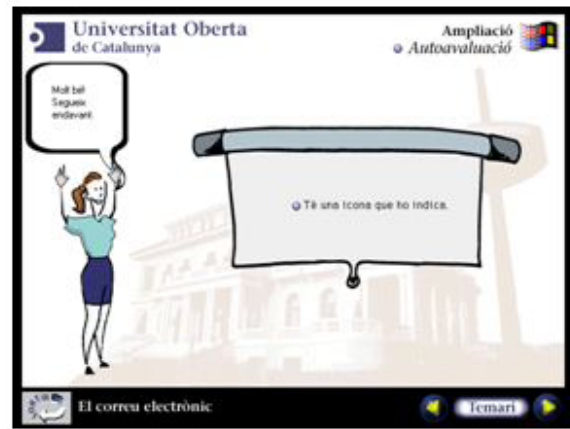

Fig. 10: Autoevaluación con resultados positivos.

\section{Lecciones aprendidas}

Una metáfora que no se adapta al sistema introduce más inconvenientes en el proceso de comunicación que beneficios para el usuario cuando hay un diseño ambiguo. Por ejemplo, en la telefonía móvil multimedia actual, los iconos de las aplicaciones del sistema operativo o aplicaciones especiales, deben ser anclados con el texto porque por sí solos conllevan a la ambigüedad y/o la vaguedad. Consecuentemente, en esos dispositivos hay un regreso a las pantallas principales de la multimedia off-line de los ' 90 , como se ha observado en la figura 1.

Ahora bien, no es fácil encontrar metáforas idóneas para las aplicaciones interactivas y variopintas, aunque se diseñe la metáfora para usuarios expertos en sistemas informáticos (Jeffries 1997). Además, no hay una solución en 
los modelos de diseño de sistemas interactivos, generados por las ciencias formales, incluyendo sus derivaciones hacia combinaciones netamente comerciales y provenientes de la educación universitaria privada, tal como es la transformación de la semiótica en una ingeniería (De Souza, 2005).

Las metáforas deben ser estructuradas, de fácil reconocimiento para los usuarios, y estar basadas en la componente visual y contextual (Halskov 1994, O'Neill 2008). Con el empleo de una metáfora familiar incluidos los iconos de la navegación, el usuario se puede obtener una comprensión del funcionamiento del sistema más fácil, intuitiva y veloz, como se ha comprobado exitosamente en los primeros sistemas interactivos de e-learning, realizados para la UOC. Esta familiaridad comunicativa es lo que favorece la orientación en la navegación de los sistemas interactivos.

\section{Conclusiones}

En el presente trabajo de investigación presentamos atributos de calidad, que potencian la comunicabilidad, y que provienen de la semiótica y la lingüística. A partir de las mismas, se pueden obtener unidades mínimas de análisis (por ejemplo, los sememes), que unidas a otras nociones provenientes del hipertexto (nodos, enlaces, índices, etc.) generan las componentes de las diferentes categorías del diseño a evaluar. Posteriormente, generando atributos y métricas de calidad es factible alcanzar resultados fiables, en breve tiempo y con costos reducidos. Todo ello, sin recurrir a los costosos modelos de las ciencias formales, por ejemplo. La semiótica y la lingüística abren un nuevo horizonte en el contexto del diseño, desarrollo y evaluaciones de la interfaces interactivas. En futuras investigaciones se irá ampliando el marco de estudio, especialmente, hacia las interfaces de los sistemas interactivos móviles e inteligentes.

\section{Referencias}

APPLE. 1992. Macintosh Human Interface Guidelines. Massachussets: Addison-Wesley.

BASILI, Victor \& John MUSA. 1991. The future engineering of software -A management perspective. IEEE Software 24(9).

CIPOLLA-FICARRA, Francisco, Maria V. FICARRA, Miguel CIPOLLA-FICARRA, Alejandra QUIROGA, Jacqueline ALMA \& Jim CARRÉ. 2018. Technology-Enhanced Human Interaction in Modern Society. Hershey: IGI Global.

CIPOLLA-FICARRA, Francisco. 1996. Evaluation and communication techniques in multimedia product design for on the net university education. Bodo Urban (ed.) Multimedia on the Net, 151-165. Vienna: Springer-Verlag. 
DE SOUZA, Clarisse. 2005. The Semiotic Engineering of Human-Computer Interaction. Cambridge: MIT Press.

ECO, Umberto. 1991. Tratado de Semiótica General. Barcelona: Lumen.

HALSKOV, Madsen. 1994. A Guide to Metaphorical Design. Communications of the ACM $37(12)$.

HAMPSHIRE, Mark \& Keith Stephenson. 2006. Strisce \& righe. Modena: Logos.

JEFFRIES, Robert. 1997. Designing Interfaces for Programmers. IEEE Software 14(6).

LAUREL, Brenda. 1990. The Art of Human-Computer Interface Design. Massachusetts: Addison-Wesley.

LE-GUERN. 1990. La metáfora y la metonimia. Madrid: Cátedra.

MITCHELL, William \& Malcom McCULLOUGH. 1995. Digital Design Media. New York: ITP. NIELSEN, Jakob \& Robert MACK. 1994. Usability Inspection Methods. New York: Willey.

NIELSEN, Jakob. 1990. Hypertext and Hypermedia. San Diego: Academia Press.

NÖTH, Winfried. 1995. Handbook of Semiotics. Bloomington: Indiana University Press.

O'NEILL, Shaleph. 2008. Interactive Media: The Semiotics of Embodied Interaction. London: Springer

SAUSSURE, Ferdinand. 1982. Curso de lingüística general. Buenos Aires: Losada.

SHNEIDERMAN, Ben, Catherine PLAISANT, Maxine COHEN, Steven JACOBS, Niklas ELMQVIST \& Nicholas DIAKOPOULOS. 2018. Designing the User Interface: Strategies for Effective Human-Computer Interaction. Vivar: Pearson Education. 


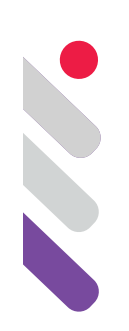

\title{
The reading contract for the customization algorithm
}

DOI: 10.24308/IASS-2019-5-003

\author{
Gustavo Markier \\ University of Buenos Aires, Argentina \\ gustavomarkier@hotmail.com
}

"Relationships between human beings suffer, often until their destruction, because of what in the contract established between them was not respected".

Bertold Brecht. Quoted by Roland Barthes, The Writing Process, 1974.

\section{Discourse as contract}

In Barthes's terms, a face-to-face course can be conceived as an implied contract.

"As in any transfer situation, it is not therefore overdetermined and is shielded after other seemingly transitive demands. Those demands form the conduits of an implicit contract between the teacher and the taught. This 'imaginary' contract does not contradict the economic determination that leads the student to pursue a career and the teacher by honoring a job" (Barthes 1974).

\section{Exposing the relational operation}

According to Kristeva (1974), “... the science of literature is an always infinite discourse, an enunciation always open to the investigation of the laws of literary practice, and in which the objective is to expose the operation that produces this 'science', its 'object' and its 'relationship', rather than empirically applying a particular technique on an indifferent object..."

Ultimately, discourse is the relationship between subjects. In discourse analysis, the enunciator establishes the conditions of his interpretation to the co-enunciator and also places limits on these. The validation of the proposed construction is forwarded to the co-enunciator (Verón 1985).

Discourse is made up of "text packages" that operate in three ways. First, by retransmitting the strict order in which the package is processed (in other words, the direction in which characters or alphabets are read). Second, by 
providing the reader a nonlinear visual "hook", such as a photograph. Third, by creating a nonlinear route using page design and typographic variations, which prompt referencing operations and can be compared to variations in intonation in spoken language (Verón, 1985).

\section{The three parts of the relational operation}

"The image of the one who speaks: enunciator. It contains the relationship between the speaker and what he says. The image of the receiver of the discourse. The producer also builds the place of the receiver. The relationship between the speaker and the receiver, which is proposed in and by the discourse." (Verón 1985).

\section{Types of reading contract}

\subsection{The 1:1 reading contract}

Building on these technical possibilities, as part of what José Luis Fernández (2018) calls the sociological-media-enunciative approach, mobile and desktop devices present us with information that is generated on the basis of the user's earlier choices. This information includes content, advertisements, and invitations to follow links, which are combined in a customized 1:1 screen. This type of reading contract could be one of the convergent crossroads that Fernández refers to, in that a new type of subjectivity is embodied in algorithms developed using artificial intelligence.

\subsection{Readers: Friendly or Suspicious}

When the customized algorithm was introduced, the appearance of contextual information while a user was surfing the web initially generated surprise and disbelief. This was followed by a second stage in the customization of certain services, one of awareness, which gave rise to two variations on the digital reading contract.

The first of these is the "Friendly" Reader, who accepts the dynamics of personalized proposals, is willing to let go, is patient, and enjoys discovering similar content that may bring satisfaction, pleasure, or fulfil their desires. An additional aspect to this is being able to share your status or preferences with others.

The second is the "Suspicious" Reader, who consciously perceives that some or all of the features of the customization algorithm generate discomfort in the form of suspicions or the feeling that they are being observed. Such users respond by rebelling against these impositions, seeking out opacity or privacy, and looking for errors, or maybe simply experience fatigue in the face of repetition and the fear of surveillance. 
Two sites that are examples of a friendly reader contract are Google News and Academia.edu, which show users news that is related to the topics they have searched for and whose services are associated with time saving. This contrasts with the sites of newspapers and online travel agencies, in which content is surrounded by contextual advertising displays and prompts readers to approach sites in a suspicious mode. Although such sites were initially perceived as services, the excessive repetition of advertising content generates everything from irritation and fatigue to blindness and indifference.

On shopping sites such as Amazon or Mercadolibre, customization is positioned as a value-added service that functions like a virtual shopping assistant, suggesting alternative of complementary purchases. Sometimes reader contracts shift, as was the case with Facebook, which gradually moved from the friendly mode to the suspicious mode as its timeline feature became increasingly complex and came to feature more advertisements. This shift was consolidated by the inclusion of third-party applications and Facebook's terms and conditions, which allow these applications access to user data and enable them to post targeted ads on user timelines.

With Twitter, user segmentation took longer, and the platform has continued to occupy a privileged position as an alternative source of information to the mass media. Users are cautious about accounts whose main purpose is clearly advertising and largely relate to content in the suspicious mode. The friendly mode predominates on many other social media platforms (Instagram, Pinterest, LinkedIn, Spotify, Shazam, Apple Music, and so on), but there is tension between the two modes on audiovisual platforms (Netflix, Amazon Fire, and Hulu). Customization in certain categories (genres, actors, directors, media type, etc.) favors the friendly mode, although there are segments of users acting in the suspicious mode that rebel in the face of recommendations when performing customized searches.

\subsection{The reading contract for customized algorithms and between humans and forms of artificial intelligence}

Statements generated by algorithms are now part of our expected interactions. Up to now, algorithms have been enunciating as producers of meaning. However, algorithms are also now enunciating from the position of the consumer/producer (prosumer) because humans generate data whenever they consume. Consequently, their consumption patterns are now part of many algorithms that draw on Big Data, the volume and complexity of which means that they tend to be run by artificial intelligence-based software, which often has components that learn from successful or negative preferences (machine learning). 
A semiotics of interfaces is now emerging, in reference to an idea of Carlos Scolari's (2015). This revolves around a new screen-human interface, the contents of which are partially or wholly created based on prior actions between humans and responses generated by artificial intelligence.

\subsection{The reading contract between forms of artificial intelligence}

A future field of study is the analysis of valid reading contracts between two forms of artificial intelligence. Indeed, papers such as this will one day be drafted by artificial intelligence.

\section{Future visions}

\subsection{Integrated apocalyptics}

As human beings our challenges are to:

- stay connected to other people and forms of Al

- generate critical analyses

- learn and master Al-based tools

- increase our abilities to generate new algorithms with objectives that reach beyond merely increasing efficiency and productivity

- actively collaborate in the design and creation of new realities.

\section{Afterword}

During my presentation at the Congress, an attendee asked me if alternative scenarios were possible in response to the circulation of discourses that are produced and consumed by Al. My answer is to propose mechanisms for interrupting a single dynamic for this in the form of disruptions initiated by human beings.

To arrive at a shared solution to the challenges of $\mathrm{Al}$, I propose that a group of researchers agree on an international coordination program to ensure that all software has an off button. This is in line with ideas and warnings that have already been formulated by thinkers that include Stephen Hawking and Elon Musk. This would perform a preventive function on par with the MoscowWashington hotline of the Cold War and would be as universally understood as the SOS signal. It would include a three- or five-character international code that would interrupt the program or Al and guarantee that humans always have the last word. This enable humans to clearly identify whether text packages are produced by other human beings or Al.

\section{References}

BARTHES, Roland. 1974. Escritores, intelectuales, profesores. In BARTHES, Roland (ed.). El proceso de la escritura. Buenos Aires: Ediciones Caldén. 
FERNÁNDEZ, José Luis. 2018. Plataformas mediáticas. Elementos de análisis y diseño de nuevas experiencias. Buenos Aires: Ediciones Crujía.

KRISTEVA, Julia. 1974. Cómo hablar con la literatura. In BARTHES, Roland (ed.). El proceso de la escritura. Buenos Aires: Ediciones Caldén.

SCOLARI, Carlos. 2015. Los ecos de McLuhan: ecología de los medios, semiótica e interfases. Palabra Clave 18 (3), 1025-1056.

VERÓN, Eliseo. 1985. L'analyse du "contrat de lecture" : une nouvelle méthode pour les études de positionnement des support presse. In INSTITUT DE RECHERCHES ET D'ÉTUDES PUBLICITAIRES, Les médias. Experiences, recherches actuelles, applications. Paris: IREP. 


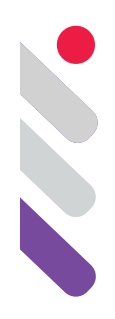

\title{
The laws of semiotics and digitalization of culture: the birth of new meanings
}

DOI: 10.24308/IASS-2019-5-004

\author{
Marina Merkulova \\ Russian State University for the Humanities, \\ Moscow City Pedagogical University, \\ Moscow Educational Channel, \\ Network publication about the theater Media Project ARTIST \\ Moscow, Russia \\ m.merkoulova@yandex.ru
}

\section{Introduction}

Culture as a system of relations between man and the world, as a sign-symbolic reality in the 21st century is transformed under the influence of universal digitalization. By 2020, the number of devices connected to the Internet will exceed 25 billion, exceeding twice the number of users. Now, a person models the world and himself taking into account new models of communication. Two types of relationships - communication and symbolic - come together, giving birth to new meanings. Having received in the hands of the 21st century new affordable communication mechanisms, every person becomes a creator, depriving professionals of a monopoly on creativity. Today is the time of universal creativity and the art of sight comes to the fore - when everyone is able to see, record and transfer to society his view of the world through selfie photos, video blogs and posts on social networks. Looking creates a symbol and the value of the symbol becomes more valuable than the value of the thing itself.

\section{Information and rights}

"Who owns the information - that owns the world".This famous expression was relevant until the end of the twentieth century. Only selected people had rights to information. The teacher stood in front of the school class and he was 
a source of knowledge. The professor wrote a book and sent it to the library. The era of the digital revolution has come and the situation has changed. The digital age gives everyone equal rights. Any person can receive any amount of information. Maybe this is generally the main advantage of the digital world every person, regardless of age, nationality, place of residence, profession, gets free access to free knowledge. Not a world, but just a dream!

The simplest example is the creation of Wikipedia eighteen years ago, a resource with which everyone could create information, send it to the Wikipedia resource, after which this information became available to any person. By the way, today information on Wikipedia is already being created not only by humans, but also by artificial intelligence.

The main question is what makes a person do this.Why did people do this with great desire? There is a well-known phrase of the Russian poet Alexander Pushkin "people are lazy and inquisitive" (Pushkin 2005) - and human psychology has not changed at all in two hundred years. I think that human life has become more comfortable and you and I have become even more lazy and curious over the years. However, the process of creating information captured people, it became fascinating for them. The reason is simple - everyone creates information about themselves. Everyone puts himself in the first place in this information. A person always wants to be a center, wants to be meaningful. In the twenty-first century, a person becomes information creator from an information user.If earlier a person was only a user of information, now in the twenty-first century he becomes the creator of information.

Professionals have lost the monopoly on creating information. The reality of the day is the universal willingness of people to leave a mark on history.A generation of twenty-first century people has a greater need for creativity than a need for absorption. Today we want to give more to the world than to take. Technological progress - the availability of mobile cameras, social networking technologies - has helped each of us become a creator.

\section{How is this process going?}

And the next question is how is this process going? All starts with a look. We see something, formulate our attitude to this object, fix it with the help of a photo, video or just text and thanks to technology, for example, social networks, we send our personal information to the general information space. In fact, we are doing a photographic self-presentation - it doesn't matter if there is video in the photo or in the text ourselves - there is our attitude, our choice, what and how we fix it. What happens at this moment with the information? Information goes into the status of "event" and becomes a "symbol", "a sign of time". The German philosopher Cassirer said: "Symbol is the key to human nature" (Cassirer 1998). The symbol gives symbolic power.While people are watching 
your photographic self-presentation, you control them. They are under your authority. You all know what "likes syndrome" is - people like your post on a social network and thereby they come under your influence. How to use these colossal amounts of information that people create today for applied and useful purposes? In Moscow, 4 years ago, the Moscow educational television channel was founded. This is a city television channel about how schools in the capital live today, how the education system is changing. There are no professional TV hosts on our channel. We came up with the idea of "television for the people," and every teacher, school director, schoolchild, parent can try himself as a TV presenter - find information, shoot it on a mobile phone and send it to us on the TV. And we thus receive information of a completely different quality - through the eyes of the audience. Their look, their choice, their attitude.

\section{Theater/Selfie}

Second example, from the sphere of theater. For many years I conducted research in the field of theater.A very closed and conservative system in which any innovation always expects active resistance.You all know, if only some theater director makes a new interpretation of the classical play, there will immediately be a big resonance: this is not Chekhov, this is not Shakespeare, that's impossible.And at the end of the twentieth century, the generation " $Z$ " was born with smartphones in hands. By two thousand and twenty, the number of devices connected to the Internet will exceed twenty-five billion, twice the number of users. Should the theater take this new reality into account and form a new system of relations with the audience in the twenty-first century? I is NOT a secret that a mobile phone is an enemy of the theater. Every evening before the performance begins in the theater they always say loudly - Do not forget to turn off your mobile phone. And this is wrong - a mobile phone gives completely new communication formats and the theater just needs to figure out how to use them to promote and advertise the theater.For example, a selfie. Fashion word. In 2012, this word was included in the top ten most popular words in the world. Today everyone comes to the theater and takes a selfie. If theaters collect this information - who is their theater audience, where do they take selfies, what do they write in the comments - these are great opportunities for analysis and decision making. To draw attention to this topic, we recently decided to come up with a new holiday. International Theatrical Selfie Day.And this is also an information management.No need to wait for someone else to officially schedule a holiday.A few years ago, one woman in England - Mar Dixon, she maintains a site about museums - she simply came up with Museum Selfie Day - announced that from January 16 every person can take selfies in museums and post them on social networks with the hashtag \#museumselfie.We decided and wrote everywhere that on April 20th every year around the world theatrical 
selfie will be celebrated, and we invited everyone to take selfies in the theater and post them on social networks.

What is this for? This is a game that people play with pleasure - and theaters receive free promotion, and our information field is filled with the theme of culture, and now the information becomes an event.And the event becomes a sign of time. The theater's entry into the media space is a new form of communication. This is an opportunity to create a new field around the performance - for discussion, for deepening. This is the ability to retell the theater audience with other means that the performance itself will not tell. Media space is a space for creating new meanings.

\section{Conclusions}

Culture has long been an area for the elite.Today, thanks to digital technology, everyone can touch culture and create their own cultural object. Culture as a system of relations between man and the world, as a sign-symbolic reality in the twenty-first century is transformed under the influence of universal digitalization.Now a person models the world and himself taking into account new communication models. Two types of relationships - communicative and symbolic - combine to give rise to new meanings.

\section{References}

CASSIRER, Ernst. 1998[1945]. Chosen: experience about man. Moscow:Gardarika, 35

ECO, Umberto. 2019 [2017]. On the Shoulders of Giants.Harvard: HarvardUP

LOTMAN, Yuri. 2001 [1996]. Universe of the Mind.A Semiotic Theory of Culture. Introduction by Umberto Eco. Bloomington: Indiana University Press

PUSHKIN, Alexander.1960 [1829].Journey to Arzrum.Complete works in 10 volumes, vol.5. Moscow: GIHL, 146 


\title{
Memória e esquecimento: ambivalências do digital entre a Wikileaks e o Facebook
}

Francisco Rui Cádima

Universidade Nova de Lisboa

frcadima@fcsh.unl.pt

\begin{abstract}
Hoje, embriagamo-nos com a tecnologia digital, enquanto somos incapazes de avaliar plenamente as consequências da nossa embriaguez. São esta cegueira e a obnubilação simultânea que a acompanha que definem a crise atual.
\end{abstract}

Byung-Chul Han (2016)

\section{Do campo dos media}

Os media, desde que são indústria, têm sido por excelência, o lugar público e de certo modo normativo em que o texto que pretende referenciar o real se expõe não como espelho, mas como fábula do mundo, como visão em segunda mão do "espectáculo" que está a acontecer e sobretudo do acontecimento irrelevante, um modo de ver reciclado em constante atualização da informação, veiculando assim discursos e narrativas cuja colagem ao real, e à relevância do que está a acontecer de facto se dilui essencialmente numa aparência de verdade.

Tratam-se de representações do real, ou mesmo de simulacros, instituídos como tal, desde logo pelo seu carácter performativo, pelo que produz ao dizer, ao enunciar, e, depois, pelas práticas de seleção, agendasetting e realinhamento ou mesmo manipulação da informação, o que nos leva para o domínio mais complexo e crítico das fake news ou mesmo dos fake media enquanto agente simulacral, antes mesmo da era da "pós-verdade". A transparência da comunicação e dos média é, assim, uma espécie de novo cárcere na modernidade, como defendeu Lyotard. 
Ora, se a história dos media pode ser interpretada como um inventário do esquecimento e de não-ditos, os meios de comunicação, e muito em particular a televisão, enquanto janela aparentemente aberta ao mundo, mais do que fazerem o inventário das figuras da raridade no sentido de Foucault, por paradoxal que pareça, fazem ascender à "dignidade" do seu écran-dispositivo, apenas um certo número de traços e factos que garantem o funcionamento simbólico e técnico-económico do dispositivo.

O mesmo é dizer que só alguns episódios, de entre a multiplicidade complexa de acontecimentos, ascendem ao campo dos media pela intermediação dos seus gatekeepers tradicionais - os jornalistas. Por exemplo, no caso dos media audiovisuais, cujo dispositivo técnico aparenta a maior transparência, estaremos perante uma cada vez maior amnésia do tempo e da virtude civil, um regime narrativo que se tem consolidado, após a fragmentação do sistema audiovisual e a multiplicidade da oferta de canais, sobretudo enquanto mimetização em cadeia de um novo modelo de agenciamento do real. A diluição e manipulação da memória e o esquecimento, por via do campo de mediação, transformaram-se assim num sistema estrutural simbólico da sociedade contemporânea.

Daí que tivéssemos defendido (Cádima, 1996) que a televisão clássica e o sistema de media em geral haviam perdido o sentido da história. O seu dispositivo evoluiu de tal forma cega, com o seu olhar tátil e manipulador sobre o quotidiano, como espelho da realidade prosaica e vulgar, que o registo telereal dos acontecimentos do mundo mais não é do que um imenso arquivo dessa arqueologia contemporânea do esquecimento.

Veja-se, como exemplo ilustrativo, o comportamento do sistema de media nas últimas décadas e o seu impacto muito negativo para as nossas vidas - tanto no plano económico, social ou simbólico, e nomeadamente para a experiência democrática contemporânea. Por exemplo, o culminar das grandes crises localizadas da mudança de século tiveram uma intervenção clara dos media na múltipla declinação da sua concretização - crise "dotcom", legitimação da invasão do Iraque, subprime, endividamento obsceno dos Estados e das famílias, disseminação de produtos tóxicos, crise financeira, etc, etc. Para alguns autores como Max Otte, por exemplo, era óbvio que havia como que uma espécie de vírus no sistema de media que fez propagar não exatamente aquilo que se conhecia como a "sociedade do conhecimento", mas sobretudo uma "sociedade da desinformação". Os media soçobravam cedendo às pressões dos grupos de interesses e dos sistemas de governo, por sua vez comprometidos com complexas lógicas de opacidade que tudo escondem, desde a necessária transparência da regulação dos sectores estratégicos, à informação financeira e à accountability dos Estados. É assim evidente que os media, de um modo geral, contribuíram para este sistema de desinformação que, pela experiência vivida 
designadamente na primeira década deste novo século, conduziu a um quase eminente colapso social generalizado do chamado mundo desenvolvido.

O historiador Marc Ferro (2017) falava-nos recentemente das cegueiras dos poderes, dos media e da própria esfera política, face não somente aos potenciais imprevistos da história, mas também à emergência de fenómenos cuja evidência, ao tempo, não pôde aparentemente ser desmentida. E dava o exemplo da chamada "televisão da insignificância" dependente das realidades de mercado e dessa "religião do directo", que, de alguma forma, impede a informação televisiva de desvelar os acontecimentos no seu próprio contexto e na sua dimensão política, na esfera da cidadania e da virtude civil, submetendo assim o seu dispositivo à atualidade latente, aos "fogos fátuos" do entretenimento vulgar e à ditadura das audiências.

Mas a verdade é que novos fenómenos emergentes - da polarização política aos populismos - continuam e aprofundam essa negação, e nada faz sugerir que não continue a ser ainda assim, para já nesta experiência do presente ou próximo futuro. E o digital, ao contrário do que supunha, apenas está a confirmar essa tendência.

\section{Wikileaks: liberdade e censura}

A Wikileaks e as plataformas de leaks e disclosures vêm introduzir um dado novo no panorama da informação e do jornalismo e sobretudo no âmbito do escrutínio da coisa pública. Os seus actores, conhecidos como whistleblowers, passaram a ser protagonistas relevantes no novo contexto mediático da era digital, isto porque vieram expandir, por assim dizer, a já de si limitada possibilidade do jornalismo afirmar a sua dimensão de "quarto poder", podendo agora contornar as vias normais de controlo da informação disponibilizada publicamente ou "libertada", e assim ultrapassando a intermediação dos tradicionais gatekeepers e as suas relações de dependência do sistema económico e político que, em regra, subvertem e degradam a própria indústria dos media e a transparência do mundo.

Esta inflexão que se dá no sistema mediático foi muito debatida e analisada por múltiplos opinion makers e pensadores. Citemos, por exemplo, Massimo Razzi, que então escrevia no La Repubblica que se estava a verificar com a Wikileaks uma viragem importante no âmbito da informação e que certamente o dia 28 de Novembro de 2010 ia ficar na história como aquele em que tudo mudou a partir da Internet, dado a disseminação do caso a partir dos jornais envolvidos nestas disclosures. Assim, para Razzi (2010), "os 'documentos' servem, em primeiro lugar, para mostrar que o rei vai nu e porque pela primeira vez, os cidadãos tiveram acesso a um tipo de segredo que a História só Ihes daria no tempo e no modo escolhidos pelos governos". Finalmente porque "foi o dia em que estes mesmos cidadãos tiveram, pela 
primeira vez, a possibilidade de dissecar inúmeros desenvolvimentos recentes e distinguir entre a verdade e as mentiras no discurso dos 'poderosos'" (Cádima, 2014: 140). Já tinha havido uma primeira divulgação de documentos a 25 de julho de 2010, quando Julian Assange publica dezenas de milhar de páginas que traziam a público diversos incidentes e relatórios sobre a guerra do Afeganistão até então desconhecidos. Passava a saber-se que os EUA tinham ocultado à sua opinião pública, quer massacres cometidos pelos talibãs, quer casos de erros militares norte-americanos, com danos civis significativos. E a 28 de novembro de 2010 dá-se então a divulgação pela Wikileaks de milhares de documentos do Departamento de Estado dos EUA, com episódios inéditos e dados de grande relevância relativos à política externa americana e que deixavam a nu segredos importantes da estratégia global dos EUA.

No contexto dos media norte-americanos e também nos europeus, o impacto das disclosures da Wikileaks teve também significativos impactos. De um modo geral ficava a ideia de que a partir dessa semana de todas as disclosures uma nova era se iniciava, e essa tinha a ver com uma nova transparência no âmbito da informação, no novo contexto de migração para o digital, o que trazia aparentemente novas garantias no antecipar de disfunções e entropias quer no sistema de media, na diplomacia internacional, ou nos equilíbrios entre potências.

A verdade é que, tal como procurámos sustentar, essa potencial hipertransparência apresentava também as suas opacidades. Veja-se o razão do surgimento da OpenLeaks de Daniel Domscheit-Berg, em resultado da sua ruptura com Assange, ainda em Setembro de 2010. Domscheit-Berg virá efectivamente denunciar que a própria plataforma de Assange tinha afinal pés de barro, e que também ela era pouco transparente. Daí que a proposta da OpenLeaks incidisse justamente numa "maior transparência de procedimentos, mais eficácia na gestão de informação, absoluta neutralidade face às tentativas de influência, clareza na gestão dos donativos, tecnologia de segurança adicional para a submissão de documentos" (Cádima, 2014: 143). Para este antigo membro da Wikileaks, as questões relativas à transparência da mediação da informação eram fundamentais, muito em particular as relações com os media e os jornalistas e as escolas de jornalismo, mas também com outras estruturas fundamentais no domínio da opinião pública, como as associações cívicas, as ONG e os próprios sindicatos.

Parte do problema tinha a ver com o facto de a Wikileaks, a partir de uma dada altura, ser incapaz de gerir de forma transparente toda a informação que Ihe chegava. Domscheit-Berg e Klopp referem então que "seriam necessários centenas de voluntários a trabalharem intensivamente para conseguirmos dar conta do recado". E acrescentavam: "Provavelmente, desiludimos os remetentes, que correram riscos e que esperam até hoje que a sua delação seja 
recompensada e que contribua para melhorar a sociedade. (...) Cada escolha é uma censura e a censura é uma interferência política" (Domscheit-Berg e Klopp, 2011: 303). Numa entrevista de Daniel Domscheit-Berg ao jornalista Paulo Moura, denunciava justamente esse outro aspecto crítico do sistema de media quando assinalava que havia previamente a opção de distribuir a informação libertada por diversos parceiros justamente para que a plataforma garantisse que não havia bloqueios por parte de um ou outro jornal. Dizia Domscheit-Berg: "Acho que a maioria dos jornalistas quer esclarecer o público. Mas por trás deles há os interesses económicos" (Moura: 2011). A diferença que DomscheitBerg pretendia introduzir com a sua própria plataforma situava-se justamente nessa nova dimensão de transparência, procurando trabalhar a informação de modo mais eficiente e melhorando os aspectos da partilha do conhecimento e da tecnologia com as próprias empresas jornalísticas, quer na forma de disponibilização online dos documentos na íntegra, na maior facilidade no contacto, mas também na privacidade da fonte e na segurança informática do sistema.

Era óbvio que estava aqui também uma forte crítica ao próprio jornalismo, argumento que era comum tanto a Assange como a Domscheit-Berg, que no seu livro reforçava claramente esse ponto de vista, denunciando os múltiplos casos de publicidade retirada ou suspensa nos media por parte de grupos económicos ou anunciantes que respondem assim quando não gostam da forma como eventualmente possam ser tratados nos media: "Seria infantil acreditar que os jornais, que se financiam por meio dos anúncios de empresas, são livres para tomar decisões sobre aquilo que publicam" (Domscheit-Berg, 2011: 306).

\section{Segredo e reprodutibilidade instantânea}

Digamos que a emergência da Wikileaks enquanto plataforma de disclosures é, fundamentalmente, a dimensão digital de algo que já era conhecido no sistema de media. O que Assange faz tinha já tido os seus precedentes, basta citar o caso dos Pentagon Papers, em 1971, ou o caso Watergate, em 1972, ou muitas outras delações de menor impacto público e mediático. Pode dizer-se que a diferença substantiva está justamente naquilo que a nova tecnologia, a Internet e os seus servidores vêm disponibilizar.

Mas, de facto, as coisas não são assim tão liminarmente transparentes e imediatas quanto possa julgar-se. Como vimos, o próprio Assange foi acusado pelos seus pares de enviesar os seus princípios e de ser o pior gestor da informação que ele próprio tinha conseguido obter e divulgado. O que significa que o caminho da transparência para a opacidade é de facto curto, ou seja, a chamada "ideologia da transparência" e os "vazamentos" dos segredos integram já os seus contrários, ou seja, a sua enunciação deve advertir-nos, por assim dizer, para a sua própria negação e contradição. De certo modo, a WikiLeaks 
transformou-se em sintoma da nossa relação com a cultura digital, isto na medida em que o projecto de Julian Assange começou por se afirmar como uma plataforma ética descodificadora e "libertadora" de todos os silêncios, violações e segredos "escondidos" pela Internet, enquanto uma espécie de dark net da política. Este seria eventualmente um caminho para repensar as engenharias de compromisso e as engenharias dos silêncios, e também a dualidade entre a "moral" do Estado, da informação e dos seus segredos, e a do cidadão. Essa seria uma primeira motivação, que rapidamente se tornou difusa.

Vejamos agora o que se passa quando, ao contrário do que acabou por suceder com a Wikileaks - que se foi apagando no tempo - pensamos essa outra realidade cada vez mais consolidada no campo do digital, a plataforma líder da Internet, o Facebook. À partida estamos, portanto, perante aquilo a que podemos chamar as ambivalências do digital, mas também perante a impossibilidade do desvelamento da "ideologia" da transparência e do segredo, e ainda perante a dificuldade maior de associar uma plataforma de partilha de informação à plena defesa e proteção dos direitos dos seus utilizadores.

Deste ponto de vista, a ambivalência e a contradição do digital começam exatamente na observação dos primeiros impactos da era digital (Cádima, 2014). Ao contrário do discurso praticamente institucionalizado e das expectativas que nos garantiam, em meados dos anos 90 do século passado que a Internet traria a inversão do modelo unívoco de comunicação da era industrial - o que se tem vindo a verificar é que o muito reduzido poder da diversidade das vozes que nascem e morrem nesse magma da World Wide Web e da Dark Web está a contribuir, não para uma cada vez maior democracia global suportada por uma maior pluralidade do sistema de comunicação, mas para a emergência de um logro, para uma fractura violenta da Web já iniciada (China Firewall, Intranet Russa, e Ocidente). Mas não só. Podemos hoje trabalhar sobre a possibilidade de existir no mundo subterrâneo da Internet aquilo a que se pode chamar uma ciberguerra entre as velhas potências dominantes das anteriores "guerras frias", uma espécie de terceira guerra mundial, mas mais "limpa" por assim dizer. De qualquer modo, de efeitos mais nefastos, segundo é já possível verificar levando em linha de conta o fenómeno dos populismos e a desinformação e polarização política que se espalha rapidamente pela Net. A memória cede então lugar ao esquecimento nesta ciberguerra pela pós-verdade, dominada por populistas suportados em estratégias de informação e propaganda e em "fake news" orientadas cirurgicamente com determinados objectivos e alvos e disseminadas por algoritmos e "robots", que convergem perigosamente numa desestabilização do sistema democrático ocidental.

Esta é, para nós, uma evidência clara, que se tem vindo a consolidar em torno das especificidades essenciais de plataformas como a Wikileaks e, mais recentemente, do Facebook - dos mitos da transparência absoluta ao 
total controlo da privacidade, dos dados pessoais e da política. Assange e a Wikileaks, por um lado, e Zuckerberg e o Facebook, por outro, tornaramse, porgressivamente, desde que os seus projetos se iniciaram nas primeiras décadas do século, num fenómeno global incontornável convocando, portanto, ao debate público a questão do segredo, da privacidade e da transparência na era da sua reprodutibilidade instantânea. Digamos que a divulgação total do segredo, as disclosures da Wikileaks, ou a exposição total da privacidade e a divulgação de dados dos utilizadores no caso do Facebook - por exemplo, os milhares de data points de cidadãos norte-americanos que a Cambridge Analytica disse deter, em grande parte fornecidos pelo Facebook, a verdade é que nenhuma destas divulgações ou exposições significam em nenhuma circunstância aquilo que poderíamos considerar um contexto de transparência do mundo, da política e dos cidadãos.

Desde logo porque se trata de dados controlados por estas organizações e dos quais apenas uma parte é divulgada e diretamente apenas aos alvos discriminados por essas mesmas organizações (jornalistas, empresas de análise de dados, etc). Depois, porque se trata de um problema teórico, e a sua interpretação não pode ser equívoca, isto é, a divulgação de um segredo não é em si mesmo uma prova de transparência pode facilmente tornar-se da ordem da opacidade. Efetivamente, mostrar é também ocultar. A obsessão pela transparência conduz então à protecção da revelação e desenvolve, por assim dizer, a ideologia da transparência a que já nos referimos. A própria "transparência" dos enunciados é enganadora, o que significa que somos de certo modo reféns da obscuridade dos textos, ou das imagens. Os seus dispositivos tecno-discursivos capturam-nos com os seus rumores, os seus espantos, os seus enganos. Esta fractura do digital, ou seja, a reversão do potencial de democraticidade da Internet, que estava assinalado na sua emergência, vem então pôr em questão o novo paradigma, dada a nova complexidade das fracturas "expostas", dos conflitos globais, tecnológicos, societais, políticos, e geoestratégicos que abrangem a recomposição do universo digital.

Para além disso, é absolutamente necessário analisar todas estas questões à luz dos enquadramentos jurídicos. Nesta perspectiva, a exposição e comercialização dos dados pessoais dos utilizadores da Web e das plataformas digitais, é claramente um delito com as características de crime público, segundo o RGPD europeu - Regulamento Geral sobre a Proteção de Dados, recentemente adoptado na Europa e também pela legislação portuguesa. Por aqui somos conduzidos agora a um outro nível do problema. Tal como Matthew Hindman (2009) defendeu, a ideia da possibilidade da Internet estar a democratizar a política global é cada vez mais uma falsa ideia, uma vez que não somente existem hoje mais desigualdades e desproporcionalidades na política online, comparativamente à esfera política tradicional, como também o essencial do 
que caracterizava o analógico está a migrar para o digital, reforçando em geral as assimetrias do passado. Mas os casos Wikileaks e Facebook ilustram ainda uma cesura entre a esfera política e os cidadãos, entre memória e esquecimento, o que remete para a dualidade entre a moral do Estado e a dos cidadãos, aparentemente reconfortados neste tempo de conversão digital e de acesso à rede, o que não deixa, no entanto, de ser perigoso em si mesmo pelo engano que representa. No fundo, estas dualidades críticas, isto é, transparência versus opacidade, memória versus esquecimento, não se estão a configurar propriamente em extremos postos porque acabam por se aproximar e criar as suas ambivalências, na medida em que todos os segredos e esquecimentos têm as suas disclosures e toda a transparência produz sempre uma gestão do que se revela e, necessariamente, também se esconde.

A relativização do segredo e da transparência, que no caso da Wikileaks está fundamentalmente associada a fontes de informação, ressurge, no caso do Facebook, inscrita na temática da privacidade do cidadão, da disseminação de arquivos digitais pessoais, e da reprodução do rumor e da informação falsa, não havendo, por assim dizer, uma salvaguarda "transparente" no plano do direito à privacidade, dos dados pessoais dos utilizadores, e menos ainda da defesa do princípio da democracia plena e participada. Esta complexa era digital da contemporaneidade, e nomeadamente a experiência específica do Facebook, quando estão em causa os contextos de "publicidade" e partilha das experiências e vivências dos cidadãos, utilizadores e produsers, constitui-se progressivamente como um sistema de censura a contrario - isto é, uma limitação ou bloqueio quer da nossa capacidade natural para lembrar, rememoriar, quer do nosso direito ao esquecimento. E através dos modelos que a plataforma permite de manipulação da informação, de controlo dos dados, um bloqueio também da possibilidade legítima de apenas querermos deixar como a nossa pegada digital os traços que admitiríamos na nossa própria memória.

Todos sabemos hoje que os agregadores de informação e os algoritmos dos novos intermediários digitais são tipicamente depositários de toda a pegada digital de um determinado utilizador. Mesmo um simples like acaba por ser informação que pode expor, de modo nunca antes imaginado por ninguém, a intimidade do cidadão, as suas crenças, sentimentos ou pulsões. Estaríamos assim já sob o espectro de um panopticon na temporalidade, na timeline dos internautas, e não, como o de Jeremy Bentham, na espacialidade, na quadrícula do espaço arquitectónico. Importa por isso, cada vez mais, e pelas melhores razões nitzscheanas, defender a importância do retorno à nossa capacidade - ou faculdade activa - do esquecimento, à privacidade do cidadão e à proteção dos seus dados. 


\section{Silêncios e programação das vozes}

Voltemos então à questão da transparência no contexto digital. Em 2009 surgia uma obra, posteriormente bastante premiada nos EUA, intitulada Delete: The Virtue of Forgetting in the Digital Age, de Viktor Mayer-Schönberger. Neste caso, um dos argumentos centrais era a questão do perigo da potencial disseminação de arquivos digitais pessoais, não havendo uma salvaguarda clara no plano do direito à privacidade e aos dados pessoais. Tratava-se, no fundo, de um alerta para o facto de, de uma maneira geral, nos preocuparmos mais com a omnipresença e os (i)mediatismos na rede - e também, paradoxalmente, com uma certa efemeridade dos nossos arquivos digitais - do que com o modo como essa informação pode permanecer e ser utilizada e redistribuída a partir de uma qualquer base de dados. Problema que, como sabemos se veio a agravar nos últimos anos. Mayer-Schönberger propõe então o princípio do esquecimento, aproximando os computadores e a computação dos processos mais específicos da memória humana, por exemplo, através da introdução de metadados nos diferentes formatos de informação, que deveriam ser codificados antes de um ficheiro ser salvo. Sherry Turkle, por seu lado, desenvolvia algumas destas questões no seu livro Alone Together, onde basicamente nos vem dizer que quanto mais conectados, mais aprofundamos, paradoxalmente, a nossa própria solidão.

O facto é que há uma perda de controlo sobre os nossos dados na rede, invertendo-se o controle sobre esses dados, havendo como que uma deslocação do poder sobre a informação, de quem pesquisa, do internauta, por assim dizer, para a plataforma de pesquisa. Como se houvesse um processo de diluição das vozes, uma espiral dos silêncios e da "solidão" dos internautas convertida em arquivo de data-points dos utilizadores. Excessos de conectividade e de dispositivos, dependências de gadgets e de redes não garantem a qualidade da comunicação. Não acrescentam valor ao processo de interaç̧ão, pelo contrário, introduzem ruído e disfuncionalidade. Numa entrevista dada ao Público (Henriques, 2012), Sherry Turkle refere que "o que as pessoas querem é estar sozinhas com as suas redes sociais", e reforçava a ideia de que a defesa da privacidade é o mais urgente: "O facto de qualquer conversa estar a ser arquivada não é bom. Eu requisitava livros na biblioteca e isso era informação protegida (...). Hoje vejo no Facebook o que é que as pessoas estão a ler e as músicas que estão a ouvir. Esta privacidade é importante ser protegida". Também na sua TED Talk de 2012, Turkle vem dizer-nos que as novas fobias são relativas ao próprio tempo real e que se as tecnologias não nos trouxerem de volta às nossas vidas então é óbvio que nos estamos a preparar para ter problemas: "Problemas certamente na forma como nos relacionamos uns com os outros, mas também problemas na forma como nos relacionamos com nós próprios 
e na nossa capacidade para a auto-reflexão". Para Sherry Turkle a palavra de ordem é agora "I share, therefore I am", porque estamos a mudar os nossos comportamentos e os processos de interação, e a habituarmo-nos a novas e diferentes formas de estarmos sozinhos e com os outros numa espécie de rede multipartilhada e de comunicação simultânea.

O ecossistema digital apela, de facto, a um novo tipo de plataformas, onde por exemplo o jornalismo colaborativo, assimétrico - entre fontes, jornalistas, leitores e produsers -, cujas temáticas, hibridez narrativa, interactividades e partilhas terão necessariamente de recusar quer as novas engenharias de compromisso que têm manietado o digital, quer os "factos alternativos" que inundam a rede, de forma a que possam ter espaço para que venham a configurar-se como uma alternativa definitiva aos modelos clássicos, que afinal de contas têm prevalecido, desde o tempo dos media enquanto empresa comercial moderna, no pós-revolução industrial, à era digital. Esta nova lógica remete para a devolução dos novos sistemas à experiência social e colaborativa, às folksonomies da cultura das redes e a novas formas emergentes de produzir, editar e distribuir informação. Os novos dispositivos técnicos da esfera digital de certa forma consagram uma conversibilidade do humano, das suas identidades, representações e mesmo das suas produções no domínio das plataformas online, enquanto novos produsers, e isso pode fazer, naturalmente, toda a diferença. Mas não tem sido exatamente assim que as coisas têm evoluído.

Coloca-se também a questão de saber se as vozes ditas "libertadas" pelas tecnologias e pela Net se se estão a reconfigurar de forma autónoma no espaço da representação e na esfera pública digital. E aqui a resposta é também, e mais uma vez, negativa (Cádima, 2015). As "vozes libertadas", são, ainda, e mais uma vez, vozes condicionadas. Como dizia Didi-Huberman, a exposição tele-real das vozes (dos povos) lança-os no caixote do lixo do espectáculo do campo dos média, o que sucede de alguma forma porque estão ameaçados na sua representação - "subexpostos na sombra da censura a que são sujeitos ou, é conforme, mas com um resultado equivalente, sobreexpostos na luz da sua espectacularização" (Didi-Huberman. 2011: 42). Por outro lado, e citando o filósofo sul-coreano Byung-Chul Han, há também que considerar o seguinte: "A sociedade de vigilância digital, com acesso ao inconsciente e aos futuros comportamentos sociais de massa, adquire traços totalitários. Submete-nos à programação e ao controlo psicopolíticos. A era biopolítica ficou para trás. Hoje avançamos rumo à era da psicopolítica digital" (2016: 92).

Memória e esquecimento reconvertem-se, por fim, em modelos de big data, o que significa que as correlações prevalecem sobre as hipóteses e as causalidades, criando uma nova grounded theory que é de certa maneira o "fim da teoria" (Chris Anderson). As ambivalências do digital esfumam-se assim neste algorithmic turn: de uma sociedade biopolítica disciplinar para uma sociedade 
psicopolítica da transparência, que coage, vigia, controla e age sobre os seres humanos enquanto "enxame digital", enquanto uma espécie de volatibilidade de dados em processamento algorítmico.

\section{Referências bibliográficas}

CÁDIMA, F. Rui. 2014. A Era Digital. Primeiro Impactos. Lisboa: Media XXI.

- (2013). O Facebook, as redes sociais e o direito ao esquecimento. Media \& Jornalismo. Lisboa: Mariposa Azual, 2013, V. 12, № 22, pp. 177-209.

- (1996). Videocultura, memória e esquecimento. Revista da Faculdade de Ciências Sociais e Humanas, no 1, pp. 83-94. Lisboa: FCSH/UNL.

DIDI-HUBERMAN, Georges. 2011. Coisa pública, Coisa dos povos, Coisa plural. In Silva, Rodrigo (Coord.). 2011. A República por vir - Arte, política e pensamento para o século XXI, pp. 41-70. Lisboa: Fundação Calouste Gulbenkian.

DOMSCHEIT-BERG, Daniel e KLOPP Tina. 2010. Nos Bastidores da WikiLeaks, Lisboa: Casa do Livro, 2011.

FERRO, Marc. 2017. A Cegueira - Uma Outra História do Nosso Mundo. Cem anos de guerra, política e religião. Lisboa: Cavalo de Ferro.

HAN, Byung-Chul. 2016. No Enxame. Reflexões sobre o digital. Lisboa: Relógio de Água.

HENRIQUES, Joana Gorjão. 2012. Cada vez mais ligados, cada vez mais sós. Público, 2, 29/7/2012.

LOZANO, Jorge, e FRANCESCUTTI, Pablo. 2012. Cuando desvelar es también ocultar. El País, 7 Deciembre.

MAYER-SCHÖNBERGER, Viktor. 2009. Delete: The Virtue of Forgetting in the Digital Age. New Jersey: Princeton University Press.

MOURA, Paulo. 2011. A WikiLeaks transformou-se naquilo que sempre combateu. Público, revista Pública, 12 de Junho de 2011, pp. 30-35.

OTTE, Max. 2010. El crash de la información. Los mecanismos de la desinformación cotidiana. Madrid: Editorial Ariel.

RAZZI, Massimo. 2010. II giorno che cambiò l'informazione. La Repubblica, 28.11.2010. 
TURKLE, Sherry. 2011. Alone Together: Why We Expect More from Technology and Less from Each Other. New York: The Perseus Books Group.

_ 2012. Connected, but alone? TED Talk, February 2012. 


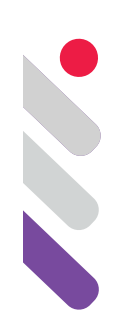

\title{
Zonas de contacto y las nuevas formas de circulación: trayectorias discursivas y participación en línea
}

DOI: 10.24308/IASS-2019-5-006

\author{
Eduardo Ruedell \\ Universidade Federal de Santa Maria \\ ruedell.edu@gmail.com \\ Viviane Borelli \\ Universidade Federal de Santa Maria \\ borelliviviane@gmail.com
}

\section{Introducción: teorias y métodos}

En primer lugar, creímos que es importante decir que estamos de acuerdo con Eliseo Verón y con los teóricos de Unisinos, en Brasil, que dicen que las sociedades contemporáneas están en proceso de mediatización (Fausto Neto 2010; Braga 2012), sin excluir, sin embargo, la acción de individuos hipermediatizados en entornos virtuales. A lo largo de nuestra investigación, nos pareció conveniente llamar a estos individuos "participantes" de la actividad enunciativa, una vez que su acción no se limita a la recepción, y tampoco a los detalles propuestos por las teorías de la coenunciación.

Una vez insertados en estos entornos virtuales, los participantes van más allá de recibir, resignificar y transmitir esas resignificaciones de los discursos incautados. Sus acciones tienen lugar en espacios construidos específicamente para la participación, y esta acción ocurre a través de la circulación discursiva (Fausto Neto 2018) bajo la forma de flujos continuos y hacia adelante (Braga 2012), que constituyen vínculos y construyen circuitos comunicativos. Sus consecuencias afectan, por tanto, severamente a la arquitectura de la comunicación en la contemporaneidad (Carlón 2018)

En este contexto, es importante decir que la revolución del acceso, una consecuencia directa de la penetración generalizada de la Internet en el tejido social, aumentó dramáticamente la complejidad de las interacciones sociales (Fausto Neto 2018; Verón 2014). Hoy, muchas de estas interacciones ocurren 
precisamente a través de la participación en entornos digitales, ya sea a través de comentarios en publicaciones en redes sociales mediáticas (Carlón 2018), intercambio de contenidos, retuits, comentarios en espacios para comentarios en sitios web, etc.

Estamos específicamente interesados en estudiar las consecuencias de la participación en espacios de comentarios de sitios web de medios de comunicación masivos. Con este fin, nos anclamos en el concepto de Zonas de Contacto, según lo propuesto por los profesores Dr. Antonio Fausto Neto y Dra. Fabiane Sgorla (2014).

Este concepto fue difundido por Mary Louise Pratt (1991), que lo define de forma generalista como un "espacio de conflictos". Ya para Fausto Neto y Sgorla, en el caso específico da la comunicación, las zonas de contacto son los "lugares" (imaginarios o materiales) que pretenden la interacción entre la producción y la recepción, o, mejor dicho, entre los participantes, que de todo modo, se constituye también de conflictos. Acerca deeso, Sgorla señala que:

Las manifestaciones de zona conducen a modalidades de contacto entre instituciones de medios y diversos actores sociales y que, en la etapa actual de mediatización, dan como resultado una nueva dinámica de contacto en la interfaz de reconocimiento de producción. Parte de esta nueva realidad se puede ver visiblemente en el contexto de la dinámica circulatoria, que impulsa los procesos enunciativos externos. El movimiento circulatorio, que toma forma, se extiende a varios modos de contacto y registros discursivos, se lleva a cabo a través de la actividad de diferentes actores sociales, emanando flujos comunicacionales específicos. (SGORLA, 2015, p. 84) [Traducción de los autores]

Este concepto presupone una estructura de tres niveles (instituciones, organizaciones e individuos). A sugerencia del profesor Antonio Fausto Neto durante el II Seminario Internacional de Investigaciones en Mediatización y Procesos Sociales, se diseñó el siguiente soporte visual de las Zonas de Contacto, evidenciando los três niveles:

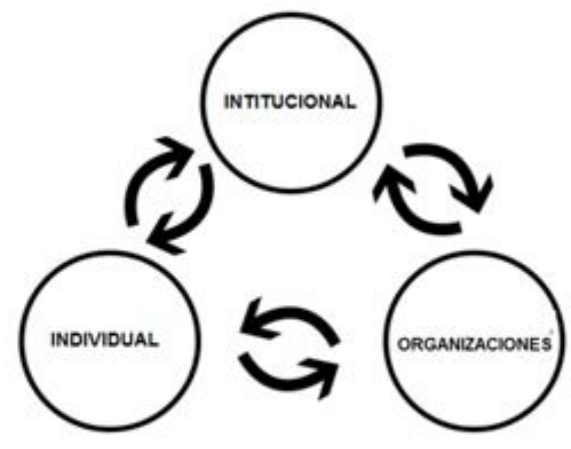

Imagen 1: Esquema de las zonas de contacto para la participación en línea. Fonte: elaborado por los autores. 
Este esquema nos permite inferir que una acción en cualquiera de estas esferas también tendrá consecuencias de diversas profundidades para las demás.

Inmediatamente se nos lleva a pensar cómo una acción individual de participar en una zona de contacto, como dejar un post en un espacio de comentarios de un sitio web o una publicación en una red social mediática, puede generar resultados en el nivel de las organizaciones de medios, y también a nivel institucional de los medios de comunicación.

La circulación discursiva juega un papel importante en la profundidad que el impacto de una acción individual puede tener en el resto de esta arquitectura comunicacional.En este punto, es importante pensar en la circulación como una maraña de procedimientos que, trabajando en forma de flujos continuos y hacia adelante, hacen circular estos discursos y sus resignificaciones, que a su vez generan nuevas resignificaciones, y así sucesivamente.

Es posible observar este funcionamiento diariamente en las publicaciones de perfiles de medios en Facebook, donde el acto de comentar, cuando resignificado, puede conducir a largas discusiones cuyas consecuencias son visibles. Podemos citar: la pasividad e sin respuesta del autor de la publicación acerca del debate incitado por el comentario, el acto de eliminar la publicación, excluir cualquiera de los comentários de acuerdo con los términos de uso (Borelli 2016), prohibir comentarios en sus publicaciones, etc.

De manera similar, cuando hay algún cambio en el nivel de las organizaciones o en la institución "Medios" en el ámbito de las Zonas de Contacto, las posibilidades de interacción a nivel individual se ven grandemente afectadas.

Sin embargo, lo que hemos observado en nuestras investigaciones llevadas a cabo en el Grupo de Investigación Circulación Mediática y Estrategias Comunicacionales (UFSM - CNPq), es que acciones de guerrilla semiológica (Eco[1967] 1986) son cada vez más frecuentes entre los individuos hipermediatizados, que utilizan estas Zonas para diferentes propósitos; un locus singular donde se producen los sentidos.

Toda la agitación causada a nivel institucional por estas acciones de guerrillas semiológicas obliga a las organizaciones a tomar medidas para regular la participación, lo que tiene consecuencias a nivel individual y, otra vez, institucional.

\section{Guerrillas y guerrilleros: ¿qué hacen las organizaciones para combatirlos?}

A lo largo de los últimos cuatro años, durante el desarrollo de esta investigación, hemos podido observar a estos "guerrilleros hipermediatizados" en acción en espacios de comentarios de redes sociales mediáticas y de sitios web de medios de comunicación masivos. Y encontramos en el campo político 
y en los discursos producidos por y para él un gran escenario.

Este fenómeno podría observarse no solo en estos momentos de gran descontento político en Brasil, como por ejemplo, el golpe de estado de 2016, con el impeachment de la presidenta Dilma Rousseff y las elecciones presidenciales de 2018, con elección de Bolsonaro; sino en todo el mundo.

Pero en particular, nos llamaron la atención los discursos producidos por los medios de comunicación masivos del Reino Unido acerca del Brexit, y aún más las estrategias discursivas empleadas por los participantes de la actividad enunciativa en los espacios de comentarios de los sitios web de estos medios (Ruedell 2018).Con el tiempo, hemos limitado nuestra mirada a un vehículo de comunicación en particular: el periódico The Guardian.

El caso de The Guardian es especial porque, según la propia organización, como lo muestran sus editores, los espacios de comentarios en noticias de temas considerados "sensibles" y que pueden generar conflictos entre sus lectores, estarán cerrados.

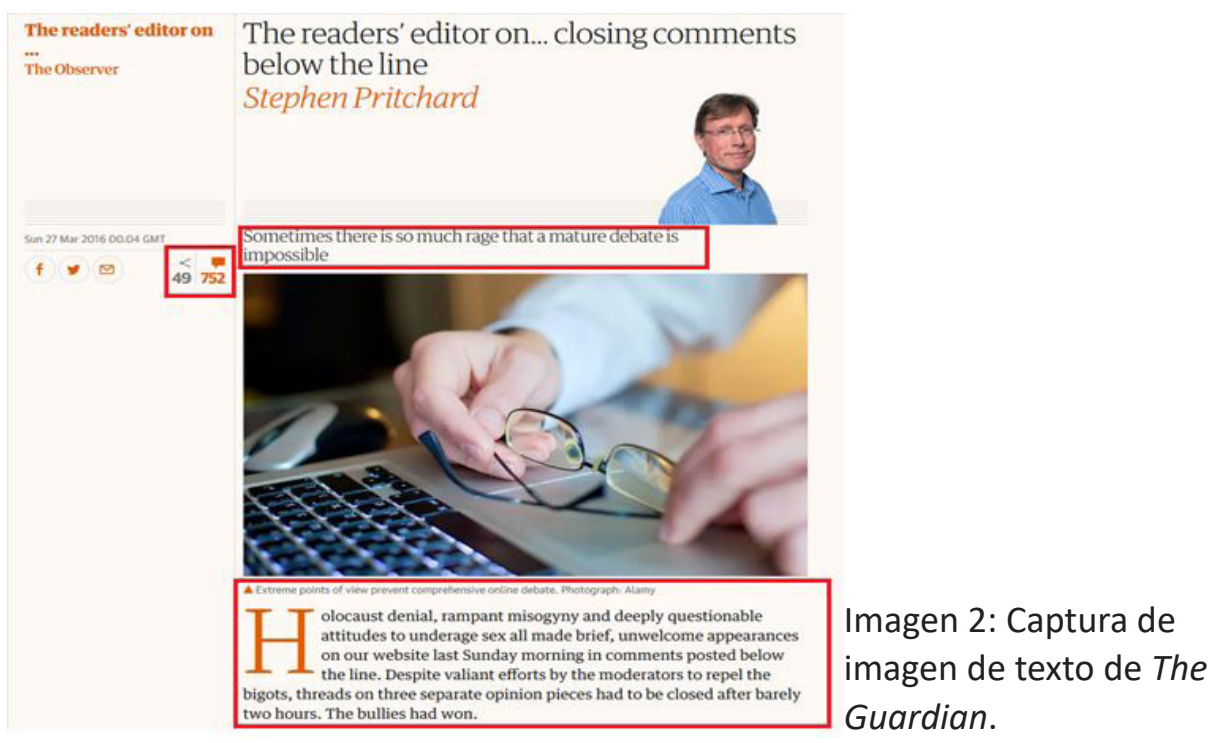

En esta primera imagen, capturada el 30 de agosto de 2019, vemos un texto del Reader's Editor de The Guardian con fecha de marzo de 2016, anterior al referendum del Brexit. Explica que "a veces hay tanto odio [en los comentarios] que un debate maduro se vuelve imposible". Es interesante observar en este caso la posibilidad de comentar y un enlace para compartir a este texto externamente.

Entendemos el acto de limitar la participación como una sanción adoptada por la organización sobre los participantes, y nos parece curioso que en un texto que propone precisamente esa sanción, en la forma de silenciar, existe la 
posibilidad de comentar y compartir, lo que puede generar, a través de flujos y resignificaciones, debates en otros espacios mediáticos, que también pueden sufrir regulaciones. Sin embargo, la regulación de estos espacios reverbera entre los participantes que cuestionan las reglas de participación y la restricción de la libertad de expresión (Borelli 2019).

En el espacio de comentarios del artículo del Reader's Editor, es posible observar las reacciones de guerrilleros hipermediatizados. Esto es lo que nos parece curioso: acciones de este tipo precisamente en un espacio de participación en una declaración favorable a este tipo de sancción. Y aunque parezca curioso, no es raro, dada la mediatización en curso en las sociedades contemporáneas, que tiene como uno de sus efectos precisamente acciones de guerrillas semiológicas así configuradas: ahora los individuos salen de sus burbujas para atacar a otros, utilizando nuevas tecnologías y nuevos medios.

\section{sniffmysmellysocks $\rightarrow$ Flatulentus 27 Mar 20165:37}

Seems the media does not like different opinions.

Share

Imagen 3: comentário. "Parece que a la media no le interezca opinioes diferentes" (Traducción de los autores).

\section{turriseburnea $\rightarrow$ previous 27 Mar $20166: 34$}

"unsympathetic (COMMA) hateful xenophobia" or just sheer commonsense? $<$ Share

Imagen 4: comentário. “'antipatia (COMA) ódio xenofóbico' o apenas senso común?" (Traducción de los autores).

krudter_uk 27 Mar 2016 6:40

Trouble is, you don't just delete the bile and hate. You also remove anything that disagrees with your editoriat line, particularly regarding religion and women's issues. Even if it's pure fact and relevant to the discussion, So please don't pretend that all deteted comments are from haters.

Imagen 5: comentário. "El problema es que usted [The Guardian] no apaga simplesmente la bilis y el ódio. También remuve todo que no está de acuerdo con su líneal editorial, especialmente lo que se refiere a religión y mujeres. Mismo que sea apenas facto y sea relevante para la discusión. Entonces, por favor, no mintas que todos los comentários deletados son obra de haters" (Traducción de los autores) 
Los ejemplos colectados entre los comentários del texto del Reader's Editor se mostran un bueníssimo modelo para conceptualizar las guerrillas semiológicas como acciones promovidas para difamar o ensalzar una ideia, un sujeto, una organización, una instituición, etc, a través de la media. Por lo tanto, no hay necesariamente violência verbal. Lo que importa es la intencionalidade del sujeto hablante.

La mediatización presenta en este punto una de sus características: si en la época en que Eco les dedicó a las guerrillas semiológicas su ensayo fundador estas acciónes se presentaban como arma de las grandes organizaciones mediáticas, hoy, con las nuevas formas de participación promovidas por la profundización de la penetración de las nuevas tecnologías e y los nuveos medios en el tejido social, quien las promove son las personas comunes, que llamanos aqui de participantes.

Ya en este segundo caso de texto de The Guardian, de la sección Law, con fecha de 2012, también capturado el 30 de agosto de 2019, un cierre institucionalizado y estandarizado por la organización todavía aún tomaría cuatro años, pero este es el anuncio de uno de los primeros cierres de espacios para comentarios en el periódico debido a las guerrillas semiológicas. Curiosamente, aquí ya no hay posibilidad de compartir el texto externamente, y no se permiten comentarios.

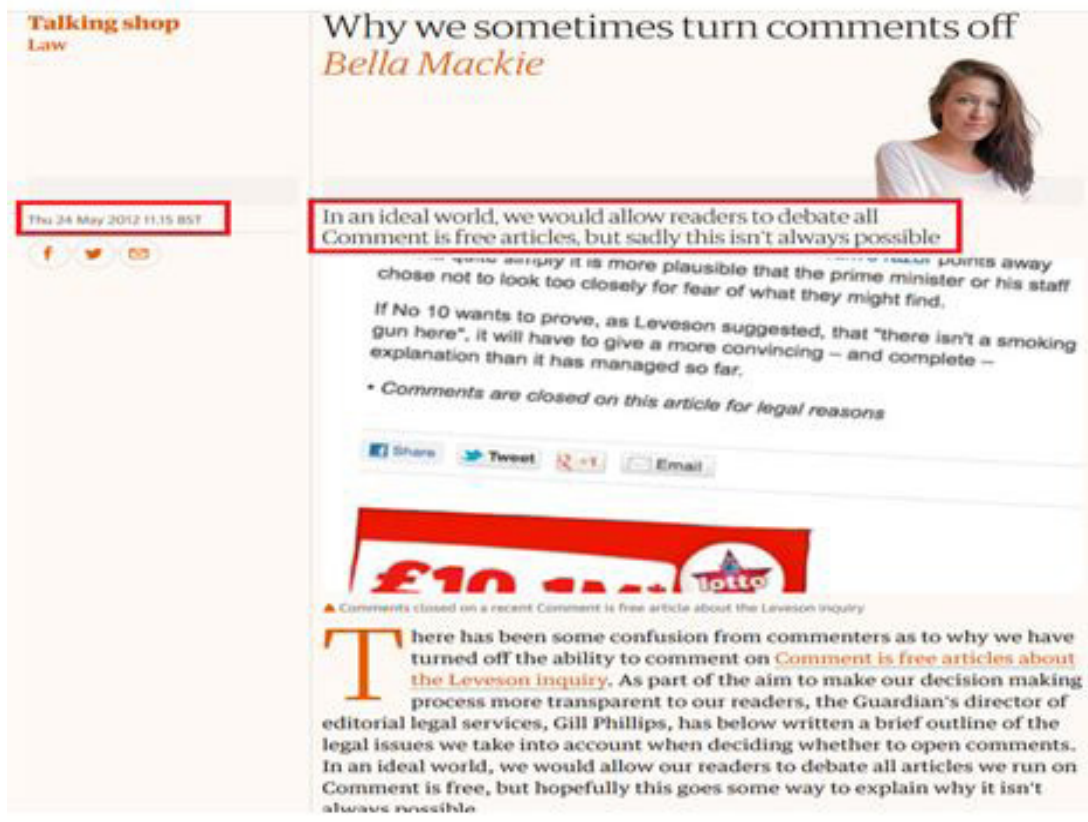

Imagen 6: Captura de imagen de texto de The Guardian 
Finalmente, en esta última imagen, capturada a la medianoche del 30 de agosto de 2019, vemos la página principal de la sección Brexit en el sítio web de The Guardian. En él podemos ver sólo un artículo con posibilidad de comentarios, y un número muy significativo de participaciones: más de 25 mil.

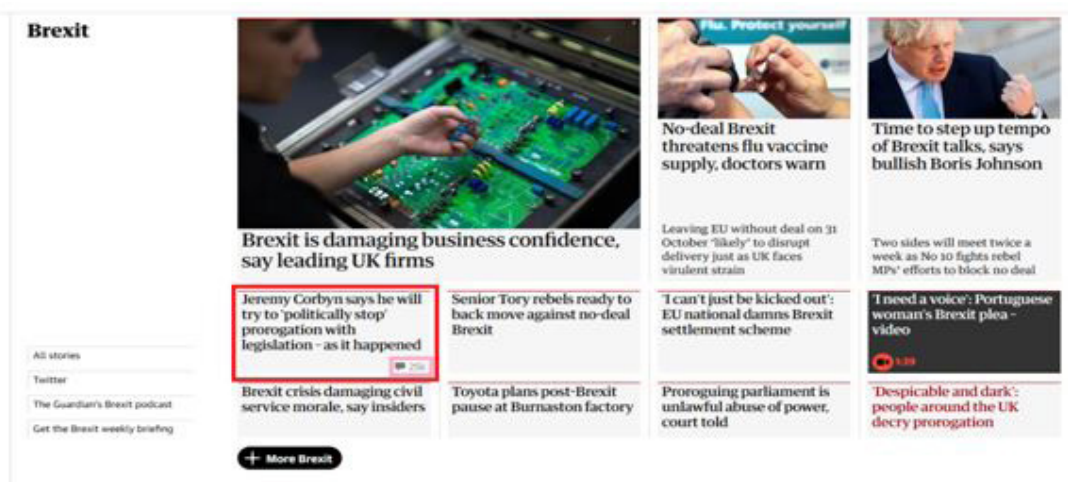

Imagen 7: Captura de la página principal de la sección Brexit del sítio web de The Guardian.

En otro momento de esta investigación, realizamos un análisis de los discursos producidos por los participantes de la actividad enunciativa en el espacio de comentarios del único texto de The Guardian acerca del resultado del referéndum del 23 de junio de 2016 que permitió comentarios (Ruedell 2018).

Es importante decir que este texto no estaba ubicado en la sección Brexit, sino en la sección World - por lo tanto, una sección con textos generales de alrededor del mundo y que, no necesariamente, hablan de temas "sensibles", y queteoricamente no deben generar debates desagradables.

A la fecha de publicación del paper con los resultados de las análisis de los discursos, hubo más de 28 mil comentarios en el texto de The Guardian. Este es un caso raro para el periódico británico, cuya participación generalmente permanece abajo del $10 \%$ de este número.

\section{Inferencias y posibles rutas para futuras investigaciones}

En el desarollar de esta investigación, fue posible observar la acción de los participantes bajo la forma de guerrillas semiológicas como he problematizado Eco (1986), resignificando el discurso primero (los textos de The Guardian) y haciendo sus resignificaciones "ir más allá" a través de la circulación discursiva bajo la forma de flujos hacia adelante (Braga 2012). 
Estos flujos continuos y hacia adelante generan debate y enfrentamientos entre los participantes, como hemos mostrado, lo que provocó el cierre de las secciones de comentarios de casi todos los textos de la sección Brexit.

Pero las consecuencias de este cierre de espacios de comentarios, no sólo en The Guardian, sino también en otros medios de comunicación masivos y también en redes sociales mediáticas como el Facebook, van mucho más allá de una sobrecarga de participación en los pocos espacios que aún están disponibles para comentar.

Lo que vemos es el cierre de las propias zonas de contacto en estos casos. Esto causa profundos efectos en el nivel Institucional de los "Medios", lo que lleva a cambios en toda la arquitectura comunicacional. También tiene consecuencias para la participación online: los individuos empiezan a programar sus acciones a fin de ser "aceptados" en el debate, buscando otros espacios para enunciar (como secciones de comentarios abiertas en otros textos del mismo periódico, en las publicaciones del periódico en las redes sociales mediáticas, en sus páginas privadas en redes sociales mediáticas, etc.), compartiendo el enlace del texto y sus impresiones al respecto de él a través de otros ambientes, etc.

Estos movimientos tentativos de participación, que emulan o intentan reemplazar la participación en espacios de comentarios donde los participantes no pueden actuar, no constituyen una zona de contacto idealentre un determinado individuo, la organización con la que desea interactuar este individuo a través de su participación, y el nivel institucional.

Pero el lugar constituido posteriormente no es, sin embargo, irreal o imaginario. Es "material",tiene materialidad significante en la arquitectura comunicacional, produce afectaciones en ella, puede generar nuevas resignificaciones de signos, formar enlaces, producir circuitos y burbujas interactivas. Por lo tanto, es un lugar de otro orden. Podemos verlo, tal vez, como una heterotopía de desviación (Foucault [1967]1994), una vez que existen tensiones concentradas producidas por las relaciones de poder en sociedades en mediatización. Por lo tanto, como el efecto de un desplazamiento de individuos cuyos comportamientos se consideran (o se suponen) "desviados" desde un espacio del orden del "mundo real", a un lugar propio para estos individuos: al margen de los territorios de los medios destinados a los "no desviados", los "civilizados".

Aunque es demasiado temprano para conocer todas las implicaciones y efectos del cierre de las Zonas de Contacto en la arquitectura comunicacional y las medidas legales en la esfera institucional de los medios, hemos podido demostrar como verdaderas las inferencias que Verón (2004) lo hizo hace casi veinte años acerca de la creciente complejidad de las relaciones sociales entre individuos en entornos digitales. 
Ya es posible observar nuevas y más complejas reorganizaciones sociales motivadas por los efectos conocidos de la participación en las esferas de las organizaciones e instituciones. Y por lo tanto, esta investigación no se cierra aquí.

Ahora es el momento de preguntar: ¿cuáles son los efectos de estas reorganizaciones en el nivel Institucional de los Medios, en los medios de comunicación masivos y qué estrategias de comunicación emplearán los participantes a partir de aquí? El desafío, sin enbargo, está en entender los procesos de comunicación que siguen en otro flujos, sean tentativos (Braga 2017) o desviantes (Verón2014), o se apresenten en movimientos transversales (CARLÓN 2018b).

\section{Referencias}

BORELLI, Viviane. 2016. Espaço para comentários de leitores em sites e perfis de jornais no Facebook: regulação, vigilância e sanções.Fronteiras 18: 230-240.

2019. Circulação e enunciação: (dis)concordâncias sobre normas de participação. III Seminário Internacional de Pesquisas em Midiatização e Processos Sociais. São Leopoldo: Unisinos.

BRAGA, José Luiz. 2012. La política de los internautas es producir circuitos. In Mario CARLÓN \& Antônio FAUSTO NETO (eds.), Las políticas de los internautas. Buenos Aires: La Crujía.

- Circuitos de Comunicação. In: BRAGA, José Luiz\& Regina CALAZANS. 2017.Matrizes Interacionais: a Comunicação constrói a Sociedade. Campina Grande: EDUEPB.

CARLÓN, Mario. 2018. Bajo el signo del presentismo: mediatización, cultura y sociedad contemporánea. In Jairo FERREIRA, Ana Paula da ROSA, Antônio FAUSTO NETO, José Luiz BRAGA \& Pedro Gilberto GOMES (eds.), Entre o que se diz e o que se pensa: onde está a midiatização? Santa Maria: Facos.

2018b. Medios individuales, medios colectivos y circulación transversal - Desde "adentro hacia afuera" y desde "afuera hacia adentro" (o como afecta la nueva circulación a las instituciones sociales). In Paulo César CASTRO (ed.),Circulação Discursiva e Transformação da Sociedade. Campina Grande: EDUEPB.

ECO, Umberto. 1986.Towards a semiological guerrilla warfare. In Umberto ECO (ed.), Travels in Hyperreality.San Diego: Harcourt.

FAUSTO NETO, Antônio. 2010. As bordas da circulação. Alceu 10: 55-69. 
FAUSTO NETO, Antônio \& Fabiane SGORLA. 2014. Zona em Construção: acesso e mobilidade da recepção na ambiência jornalística. Lumina 7.

FOUCAULT, Michel. 1994. Des espacesautres. In Michel FOUCAULT, Ditsetécrits 1954-1988, t. IV (1980-1988). Paris: ÉditionsGallimard.

PRATT, Mary Louise. 1991. Arts of the Contact Zone. Profession: 33-40.

RUEDELL, Eduardo. 2018. Enunciação, referência e coenunciação. // Seminário Internacional de Pesquisas em Midiatização e Processos Sociais. São Leopoldo: Unisinos.

SGORLA, Fabiane. 2015.Complexificação da Zona de Contato na ambiência midiatizada. São Leopoldo: Unisinos.

VERÓN, Eliseo. 2004. Fragmentos de um tecido. São Leopoldo: Unisinos. 2014. La Semiosis Social 2. Barcelona: Ediciones Paidós. 


\section{DIGITALIDAD Y ARTES}





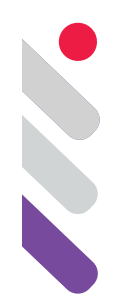

\title{
Semiótica das interações no audiovisual: produção de sentidos no clipe interativo "Saturn Barz"
}

DOI: 10.24308/IASS-2019-5-007

\author{
Bárbara Heliadora Cavalcante Fontenelle \\ Murilo ScOz \\ Universidade do Estado de Santa Catarina, Brasil \\ barbarahcfontenelle@gmail.com \\ muriloscoz@gmail.com
}

Dedico essa pesquisa à memória do professor Murilo Scoz. A ele, toda minha gratidão pelo apoio, incentivo, serenidade e companheirismo dos últimos anos.

\section{Introdução}

O percurso gerativo proposto pela semiótica greimasiana é um modelo de produção e interpretação do sentido. Segundo Fiorin (2016), trata-se de um esquema de análise com patamares a serem descritos, em um processo que vai do nível mais simples e abstrato ao mais superficial e concreto. $\mathrm{Na}$ intersecção com o campo do design gráfico, esse modelo tem sido utilizado em estudos sobre a significação de artefatos como projetos editoriais, embalagens, discursos de marca, projetos de sinalização, narrativas gráficas, quadrinhos, merchandising, vinhetas, animações e em tantos outros objetos ligados ao fazer projetual. Mais recentemente, diante do novo paradigma tecnológico colocado pela digitalização, alguns estudos têm também investigado os processos de produção de sentido no âmbito dos dispositivos interativos, na busca de melhores condições de usabilidade.

Com o crescente surgimento de novas possibilidades tecnológicas, o design de interação tem como papel facilitar o uso desses artefatos para o público-alvo, de forma a entender suas dificuldades e traduzi-las em soluções acessíveis nos dispositivos interativos.

Em paralelo, a semiótica francesa vem expandindo seus estudos para relações que se encaixam na definição de "práticas interacionais", onde o processo de produção dos efeitos de sentido se dá conforme ações de interactantes. Diferente dos textos, em que a análise está focada no conceito de 
uma totalidade de sentido, no domínio das práticas sociais o foco recai sobre os possíveis efeitos de sentido que emergem através das interações.

Dessa forma, levando em consideração o processo de desenvolvimento de dispositivos interativos com foco no ser humano e o conceito semiótico de prática social, a pesquisa em questão pretende demonstrar como a semiótica francesa pode servir de perspectiva teórica para a abordagem da produção do sentido em nossa relação com artefatos do design de interação, tomando como objeto de análise o videoclipe interativo 360 Saturnz Barz, lançado em 2017 pela banda Gorillaz.

Nestes termos, o presente estudo toma como problemática geral as dinâmicas de emergência do sentido nos dispositivos digitais, discutindo o papel narrativo dos recursos ditos interativos. Para isso, serão retomados fundamentos da semiótica francesa e seu percurso gerativo do sentido, bem como conceitos acerca da sociossemiótica e sua contribuição para o design de interação.

\section{Fundamentação teórica}

\subsection{Design de Interação}

Para Preece, Rogers, Sharp (2002), o design de interação busca desenvolver experiências de uso que aprimorem e ampliem a forma como as pessoas dialogam, trabalham e interagem diariamente. Sistemas inteligentes e automatizados estão presentes em diversos utensílios do cotidiano, desde artefatos que visam facilitar tarefas rotineiras até os que buscam explorar recursos pouco utilizados no seu respectivo segmento. A interação com esses produtos se dá através de uma interface, definida para Moran (1981) como a componente com a qual a pessoa entra em contato, seja de forma física, perceptiva ou conceitualmente.

Durante o desenvolvimento de dispositivos interativos, é possível que as variáveis de uso não recebam a devida atenção, o que pode levar a graus de eficiência insatisfatórios, quando da análise de sua manipulação pelos usuários que de fato terão contato com aquela interface. Isso acontece por conta da não consideração de parâmetros mais amplos de usabilidade no processo de desenvolvimento, recaindo sobre o profissional de design de interação a responsabilidade de agregar essa preocupação ao projeto.

Preece, Rogers, Sharp (2002) consideram a usabilidade como o fator determinante para que os produtos sejam fáceis de usar, eficientes e agradáveis, sob a ótica do usuário. De acordo com Nielsen (2003), a usabilidade é o atributo de qualidade que avalia a facilidade de utilização de uma interface e pode ser validada através de dez heurísticas: visibilidade do estado do sistema; mapeamento entre o sistema e o mundo real; liberdade e controle ao usuário; consistência e padrões; prevenção de erros; reconhecer em vez de lembrar; 
flexibilidade e eficiência de uso; design estético e minimalista; suporte para o usuário reconhecer, diagnosticar e recuperar erros; ajuda e documentação. Em conjunto, esses aspectos avaliam o quanto o dispositivo apresenta-se acessível à assimilação por parte do usuário, capaz de prevenir erros e evitar acidentes.

Ao longo das décadas de evolução dos sistemas digitais foram sendo incluídas no processo de desenvolvimento desses produtos preocupações ligadas a áreas como psicologia, fisiologia, ciências cognitivas, semântica interfacial, entre muitas outras para que fosse possível dar conta das complexas condições da interação humano-computador. Com o aprimoramento tecnológico e midiático da era digital, cineastas, fotógrafos, produtores de vídeo, designers de games, animadores e diferentes tipos de artistas visuais viram-se atraídos pelas possibilidades da interatividade, dando origem a produtos e sistemas diversos que tensionaram os limites do design de interação. Desta forma, novos modelos teóricos vêm sendo examinados no estudo deste campo em transformação, no intuito de esclarecer os fenômenos ligados à interatividade e de explorar seu potencial.

\subsection{Semiótica francesa e o percurso gerativo de sentido}

Entre os principais direcionamentos teóricos semióticos, a vertente chamada estrutural teve origem entre pesquisadores franceses a partir dos estudos linguísticos iniciados pelo suíço Ferdinand Saussure, que tratou a ideia de linguagem como um sistema de relações. Os fundamentos estabelecidos por Saussure foram incorporados pelos linguistas modernos, tendo servido como base conceitual para a pesquisa realizada por Algirdas Julien Greimas e seus colaboradores. Reunidos na chamada Escola de Paris, o grupo de Greimas deu contornos à chamada Semiótica Francesa (ou discursiva) tomando como objeto de estudo o fenômeno da produção do sentido. Seu principal objetivo é "estudar o discurso com base na ideia de que uma estrutura narrativa se manifesta em qualquer tipo de texto" (Oliveira, 2009). Assim, passou-se a entender por "texto" qualquer objeto no qual exista uma totalidade de sentido, independentemente de sua forma de manifestação, seja ela verbal, sonora, visual, gestual ou mesmo híbrida.

A partir desta definição, a semiótica francesa considera que a construção do sentido do texto ocorre através de um percurso gerativo, que é, segundo Fiorin (2016) "uma sucessão de patamares, cada um dos quais suscetível de receber uma descrição adequada, que mostra como se produz e se interpreta o sentido, num processo que vai do mais simples ao mais complexo"

A primeira etapa desse percurso é a do Nível Fundamental, onde encontram-se as estruturas semânticas sobre as quais se constrói o texto, representadas por uma oposição de base formada por dois termos contrários entre si. A seguir, tem-se o nível Narrativo, que comporta as sequências de 
transformação entre dois estados diferentes através de uma estrutura narrativa canônica. Semioticamente, uma narrativa é constituída pela articulação de quatro fases subsequentes: manipulação, competência, performance e sanção, abordadas a seguir com maior detalhamento (voltar a isso mais pra frente...). Tanto o nível Narrativo quanto o Fundamental se concretizam no nível mais superficial, chamado Discursivo. Nele, estão englobados os elementos mais concretos e complexos, que correspondem às figuras e aos temas utilizados pelo autor na construção do texto. Também na sintaxe do nível discursivo, analisamse as marcas do processo de enunciação, com especial atenção às relações que se estabelecem entre enunciador - a imagem que o texto carrega de seu autor - e enunciatário - a projeção discursiva do destinatário do texto.

Para a semiótica francesa, os elementos que compõem o percurso gerativo constroem um modelo do chamado plano do conteúdo, que é então descrito como um simulacro da maneira como o texto poderia ter sido produzido por seu autor. Por outro lado, considera-se também, para fins de análise, os elementos que compõem a chamada manifestação dos textos, que integram o chamado Plano da Expressão, onde encontram-se elementos de natureza plástica. Nos sistemas semióticos, a articulação entre expressão e conteúdo constrói a chamada textualização, ou seja, a produção do sentido. Assim, é importante assinalar que o processo de significação para a semiótica estrutural se dá dentro do próprio texto, ou seja, a partir de um sistema de relações entre os elementos textuais. Em artefatos interativos com diferentes formas de manifestação, ou seja, que utilizam tanto recursos visuais como sonoros, verbais, materiais e até mesmo a gestualidade, o semi-simbolismo pode ser adotado para explicitar as condições de articulação entre a expressão (forma) dos sistemas interativos e o conteúdo (sentido) produzido.

Em seu desenvolvimento, a semiótica francesa passou a analisar as práticas sociais, mantendo seu objeto de estudo ligado às condições de emergência do sentido. Nestes termos, de uma semiótica dos textos, pudemos reconhecer a passagem a uma abordagem sociossemiótica, dedicada sobretudo ao conceito de interação.

\subsection{Sociossemiótica para o design de interação}

A partir destes desdobramentos epistemológicos, os estudos semióticos têm voltado sua atenção para o fenômenos da produção de sentido nas práticas. Isto implica que a significação não está fechada nos limites do texto, mas aberta a dinâmicas interacionais distintas que não se deixam descrever apenas em termos narrativos. A partir desta acepção, podemos igualmente imaginar que os artefatos do design de interação operam por tal lógica semiótica, ou seja, são "praticados" pelos usuários. 
Segundo Scoz (2018), as tecnologias desenvolvidas nas últimas décadas propiciaram novos processos interacionais, o que em termos sociossemióticos pode ser descrito como novas práticas construtoras de sentido. A partir desta corrente, tributária da ideia de narratividade proposta por Greimas, o sentido passa a ser tomado pela dinâmica do valor dos objetos dentro de percursos narrativos. Como teoria da ação, esta perspectiva explica as interações humanas a partir da relação entre sujeitos que perseguem seus objetos de valor. Assim, segundo tal perspectiva narrativa, os sujeitos "definem-se nas transformações que sofrem a medida que se aproximam de seus propósitos, que necessariamente precisam estar claramente colocados desde o início." (Scoz e Motta, 2016) Por outro lado, Landowski propõe um modelo ainda mais amplo de interações que não se define inteiramente por tal lógica pré-determinada. Segundo o autor, tais interações estariam ligadas a sentidos abertos, tornados possíveis a partir de interações da ordem da sensibilidade. Neste tipo de regime, próprio das relações entre sujeitos, surgem significados imprevisíveis e sem a circulação de objetos de valor.

No modelo interacional de Landowski, consideram-se as circunstâncias subjetivas presentes nas práticas sociais, havendo a presença de quatro regimes distintos de interação. Dentre essas possibilidades, apresentadas no esquema a seguir, as categorias semânticas são mapeadas levando em conta "o nível de previsibilidade envolvido em cada forma de interação, dado que um processo interativo pressupõe a relação entre actantes." (Scoz e Motta, 2016)

PROGRAMAÇÃO total previsibilidade regularidade

MANIPULAÇÃO alta previsibilidade intencionalidade
ACIDENTE total imprevisibilidade aleatoriedade

\section{AJUSTAMENTO alta imprevisibilidade sensibilidade}

[Imagem 1: Regimes de interação de Landowski]

Segundo tal esquema, interações totalmente previsíveis onde os interactantes agem conforme protocolo inquebrável correspondem ao conceito 
de Programação, e são regidas pelo princípio da regularidade. Os casos em que há um plano de ação pré-estabelecido pelos sujeitos, mas no decorrer do trajeto, ocorre um evento inesperado, são encaixados na definição de Acidente, marcados pela imprevisibilidade e governados pela ideia de aleatoriedade. Logo, temos uma oposição inicial que se estabelece entre este regime e o da programação. Há também as interações com ações intencionais por parte de um sujeito manipulador sobre um manipulado, correspondendo ao conceito de Manipulação. A definição de manipulação equivale ao ato de levar alguém a fazer alguma coisa, sendo portanto regida pelo princípio da intencionalidade. Por último, existe o conceito do Ajustamento, onde ocorre uma interação direta entre actantes que já estão dispostos a uma troca imediata de competências sem a necessidade de uma interferência manipulatória, sendo regido assim pelo princípio da sensibilidade.

\section{Videoclipes interativos}

Os videoclipes interativos vêm apresentando uma proposta inovadora ao fazer com que o espectador assuma um papel decisivo dentro da narrativa, em maior ou menor grau. No caso de Saturnz Barz, da banda Gorillaz, é feito uso do recurso de visualização em $360^{\circ}$, permitindo que o "espectador" possa escolher o enquadramento de sua preferência para cada cena enquanto a narrativa visual decorre por conta própria. Assim, é oferecida ao destinatário do texto uma posição interacional mais ativa, facultando a ele a escolha de pontos de vista. Apesar disso, é importante ressaltar que há uma versão do mesmo videoclipe que posiciona enquadramentos e segue um fluxo fechado e linear em sua montagem, sem a possibilidade do recurso interativo descrito. Dessa forma, como buscamos demonstrar, a versão interativa parece reprogramar o papel daquele destinatário passivo, modalizado agora com um poder de escolha, com o propósito de enfatizar os valores abordados no modelo fechado do objeto.

A versão que segue um fluxo fechado do videoclipe em questão inicia com um travelling (movimento de câmera em que ocorre deslocamento espacial contínuo e sem cortes) que permite visualizar a lateral de uma casa ao mesmo tempo que ouve-se ao fundo uma outra canção da mesma banda (Ascencion) com volume em ritmo crescente, criando a noção de aproximação de alguém. Ao final do travelling, o enquadramento foca em uma rua onde é possível ver um carro direcionando-se à fachada da casa, onde estaciona ao mesmo tempo que a música para - consequentemente, compreende-se que a canção vinha de dentro do veículo. Ao descer do carro, os personagens do Gorillaz vão até a casa, tocam a campainha e são surpreendidos por uma tempestade que começa e pela porta que abre-se sozinha. Eles dialogam sobre a estranheza desse último acontecimento, e decidem separar-se para averiguar diferentes cômodos da casa vazia. A canção Saturnz Barz começa a tocar quando a personagem Noodle 
encontra um disco de vinil e o coloca para reproduzir, e então os membros da banda passam a ser assombrados por figuras monstruosas que habitam a casa. Ao final, quando todos voltam para o cômodo onde iniciaram as assombrações, a tempestade acaba e eles deixam a casa, aparentemente não afetados pelos eventos que se seguiram.

A seguir, apresenta-se a transcrição de trechos a letra e dos diálogos ao longo do clipe.

Tabela 1 - Diálogos do videoclipe e letra de Saturnz Barz

\begin{tabular}{|c|c|}
\hline \multicolumn{2}{|c|}{ Versos que podem ser ouvidos de Ascencion } \\
\hline $\begin{array}{l}\text { I'm just playing, baby, this the land } \\
\text { of the free } \\
\text { Where you can get a Glock } \\
\text { And a gram for the cheap }\end{array}$ & $\begin{array}{l}\text { Eu estou apenas brincando, baby, } \\
\text { isso é a terra dos livres } \\
\text { Onde você pode conseguir uma } \\
\text { Glock } \\
\text { E uma erva baratinho }\end{array}$ \\
\hline \multicolumn{2}{|c|}{ Diálogo anterior ao começo da música } \\
\hline $\begin{array}{l}\text { Murdoc: Loudest doorbell I ever } \\
\text { heard. }\end{array}$ & $\begin{array}{l}\text { Murdoc: Campainha mais alta que } \\
\text { já ouvi. }\end{array}$ \\
\hline 2-D: Looks like a fixer-upper. & 2-D: Parece que precisa de reparos. \\
\hline Russ: Hmm, welcoming. & Russ: Hmm, acolhedor. \\
\hline $\begin{array}{l}\text { Murdoc: A little too welcoming I } \\
\text { say. }\end{array}$ & $\begin{array}{l}\text { Murdoc: Um tanto acolhedor } \\
\text { demais, eu diria. }\end{array}$ \\
\hline $\begin{array}{l}\text { Russ: Should split up and take a look } \\
\text { around. }\end{array}$ & $\begin{array}{l}\text { Russ: Devíamos nos separar e dar } \\
\text { uma olhada em volta. }\end{array}$ \\
\hline $\begin{array}{l}\text { Murdoc: Great idea Russ, always } \\
\text { works out well in horror movies. }\end{array}$ & $\begin{array}{l}\text { Murdoc: Boa ideia Russ, sempre } \\
\text { fuciona bem nos filmes de terror. }\end{array}$ \\
\hline
\end{tabular}




\section{Letra da música}

Monsters:

All my life

Mi ever have mi gun so mi haffi (sic)

Move sharp like mi knife (sic)

Mi pray say when mi get wealthy (sic)

A ma a mi wife (sic)

The system force mi (sic)

Fi be a killer just like Rodney Price (sic)

All my life mi dream fi own house Land, cars and bikes

2D:

I'm in the stakin' bar

I got debts and I'm a debaser

Saturnz about to make love

And I'm just a heartbreaker

And I won't get a take in 'cause I'm out when I'm stakin' And the rings I am breaking

Are making you a personal day

With the holograms beside me I'll dance alone tonight

In a mirrored world, are you beside me
Monstros:

Eu nunca tive uma arma, então sempre tive que ser afiado como uma faca

Eu disse que quando tivesse dinheiro, eu me casaria

O sistema me forçou a ser um assassino como Rodney Price

Toda a minha vida

Meu sonho é ter minha casa, propriedades, carros e motos

2D:

Eu estive em bares de apostas

Eu tenho dívidas, eu sou desprezível Saturno está pronto para fazer amor E eu sou só um destruidor de corações

E eu não vou conseguir nada Porque eu estou fora quando estou apostando

$E$ os anéis que eu quebro

Estão te transformando em uma dívida pessoal

Com os hologramas ao meu lado Eu vou dançar sozinho esta noite Em um mundo espelhado, você estará comigo 


\section{Diálogo após membros da banda saírem da casa}

\begin{tabular}{|l|l|}
\hline Murdoc: Breakfast? & $\begin{array}{l}\text { Murdoc: Café da manhã? } \\
\text { Russ: Oh yeah. I got a real appetite. }\end{array}$ \\
2-D: Just a peppermint tea for me. & $\begin{array}{l}\text { Russ: Com certeza. Estou com um } \\
\text { grande apetite. }\end{array}$ \\
& $\begin{array}{l}\text { 2-D: Só um chá de hortelã para } \\
\text { mim. }\end{array}$ \\
\hline
\end{tabular}

\subsection{Nível discursivo}

O nível discursivo é o mais superficial e concreto do percurso gerativo de sentido. Partindo do objeto de análise em questão, percebe-se a abordagem de quatro temas diferentes, que são as ideias abstratas de natureza conceitual sobre as quais se materializa o texto. O primeiro tema seria o do Gênero cinematográfico terror, enfatizado pelo diálogo inicial dos personagens, que resolvem seguir uma estratégia de exploração da casa característica dos filmes que se encaixam nessa categoria, como eles próprios afirmam. O tema também se concretiza em figuras que remetem a espíritos e fantasmas, como a face humana que aparece em uma abertura da lateral da casa nos 24 segundos de vídeo, os monstros que interagem com os membros da banda, objetos inanimados que ganham vida e a ideia de casa fantasma a ser explorada.

O segundo tema abordado é a ideia da llusão, materializado nas figuras da camiseta do personagem Russel com a frase Its not Rael ("Não é real", em tradução), que apresenta um anagrama da palavra real, criando um efeito de sentido de deformação da realidade, e na transposição do ambiente da casa abandonada com o espaço sideral. A temática da Violência urbana é concretizada em alguns versos cantados pelos monstros e também na segunda estrofe de Ascencion que é escutada no início do vídeo, onde é feita uma crítica direcionada à cultura norte-americana e seu porte de armas. Por último, o tema da Ascensão profissional é materializado pelos versos em que Popcaan descreve seus desejos de consumo para quando conquistar a riqueza.

O que percebe-se a partir disso é que algumas figuras associadas ao tema do terror dão voz ao longo do fluxo do vídeo aos versos ligados à temática de violência, aspecto relacionado à realidade de seres humanos. Portanto, uma possibilidade de efeito de sentido seria que esses monstros corresponderiam a fantasmas de um passado violento que os membros do Gorillaz não tenham 
dado devida atenção. É interessante destacar também que na sequência inicial do vídeo são apresentadas ao longo do travelling diferentes figuras associadas a outros videoclipes da banda, comportando-se dessa forma como elementos intertextuais que recuperam outras obras da banda e as introduzem no mesmo universo fantasioso de Saturn Barz.

A sintaxe discursiva dos versos que compõem as duas vozes da canção (a dos monstros e a do personagem 2D) apresentam debreagens enunciativas, com discursos em primeira pessoa, o que acaba atribuindo ao texto um caráter mais subjetivo e testemunhal, produzindo juízos de interpretação ao invés de um discurso objetivo. A voz dos monstros demonstra certo distanciamento temporal de sua própria história, enquanto a voz do membro da banda Gorillaz encontra-se no tempo presente.

\subsection{Nível narrativo}

A narrativa central do videoclipe se constrói a partir da busca dos personagens do Gorillaz pela experiência fantasiosa pela qual passam. Esse desejo intencional de viver os acontecimentos fica pressuposto pelo fato de que a chegada à casa abandonada aparenta ser proposital, e após a sequência fantástica no espaço e com os monstros, os membros da banda quando retornam ao carro não aparentam medo ou surpresa decorrentes da experiência. Dessa forma, apesar do estranhamento inicial para alguns aspectos da casa (campainha, receptividade atípica), a trivialidade com qual os personagens agem subentende que aquele tipo de experiência seja regular em suas vidas.

Pode-se considerar que ocorre uma manipulação por tentação por parte dos membros do Gorillaz sobre eles mesmos, correspondendo aos sujeitos 1 e 2 dessa etapa, pressupondo que houve uma decisão anterior ao videoclipe de que sairiam em busca de uma experiência alucinógena esperando uma sensação positiva com a qual já estariam habituados. Aliado a esse fato, a etapa da competência estaria relacionada à expectativa de que a casa abandonada onde chegam teria os recursos necessários para proporcionar a eles essa experiência. Os objetos modais se concretizam nos gatilhos anteriores à alucinação para cada membro da banda, manifestando-se em forma de comidas para o personagem 2D, no ato de imergir na água de uma banheira para Murdoc, no sono de Russel e na música que Noodle coloca para tocar. A performance corresponde à sequência de interações com os monstros, desconstrução da casa e navegação em torno dos anéis de saturno, indicando a passagem do estado sóbrio para o lisérgico. A conjunção com o objeto de valor se dá, nestes termos, pelo encontro com esta experiência de fantasia e alucinação, em que os personagens são levados a viver uma espécie de transe através dos cômodos da casa. Uma sanção é em seguida construída quando ao final da noite, já na manhã seguinte, os personagens retornam ao cenário original da casa nos locais onde tiveram 
contato com seus respectivos gatilhos. Após voltarem para o veículo que os trouxe até o imóvel, e a despeito da experiência extraordinária vivida pelo grupo, ocorre um diálogo absolutamente trivial, no qual discutem a ideia de tomarem café-da-manhã, pressupondo que a experiência levou a duração de uma noite inteira para acontecer. A proposta reitera, em certa medida, a ideia aqui sustentada de que a sequência narrativa apresentada metaforiza um período de consumo de substâncias narcóticas, cujo efeito colateral recorrente é a fome, o que justificaria o apetite dos personagens. A reação de 2D ao diálogo, informando que deseja apenas um chá de hortelã, indica também esse estado de desgaste do organismo após uso de drogas

\section{$\mathbf{S}_{1}$
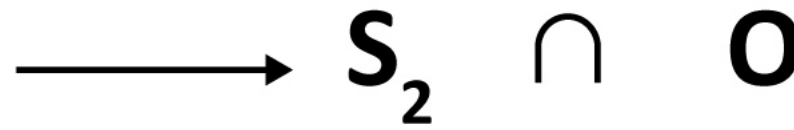 \\ Gorillaz \\ Gorillaz \\ Experiência alucinógena}

[Imagem 2: Esquematização da sequência narrativa].

\subsection{Nível fundamental}

Segundo Fiorin (2016, pg. 21) "A Semântica do nível fundamental abriga as categorias semânticas que estão na base da construção de um texto". A partir do exposto na análise dos dois níveis anteriores, uma possível oposição de base para o objeto aqui analisado seria /realidade/ vs /fantasia/, o que se justifica pela alternância entre um mundo tido como normal e um outro claramente marcado por alucinações, criaturas fantásticas e elementos surreais.

Há um primeiro momento de afirmação da /realidade/, implícito pelo desejo dos membros da banda de entrarem em conjunção com a experiência fantasiosa e a busca pelos gatilhos, o que é observado com a chegada proposital da banda à casa abandonada. Em seguida, a realidade é negada pela afirmação da /fantasia/, que pode ser observada quando a experiência de alucinações começa a de fato acontecer por meio da narcose (os objetos modais apontados no nível narrativo), e, ao final, os personagens apresentam reações de aversão à experiência, como calafrios e tremedeiras. Por último, ocorre novamente a afirmação da /realidade/, que mesmo com sua trivialidade mostra-se uma opção segura e confortável. Isso fica evidente quando os personagens ao saírem da casa e retornarem ao carro não demonstram infelicidade pelo fato de a fantasia ter acabado, o que torna a /realidade/ o valor eufórico. 


\section{Regimes de interação no videoclipe interativo}

A versão interativa do videoclipe de Saturnz Barz apresenta como regime programado o controle de enquadramentos $360^{\circ}$ por parte do interactante, ao mesmo tempo que o fluxo de cenas e ambientes apresentados segue por conta própria, sem possibilidade de interferências. Na prática, isso representa autonomia parcial ao usuário, sendo aspectos que exigem poucos conhecimentos específicos por parte do interactante para que consiga realizar as ações planejadas.

No objeto analisado em questão são poucas as ações que poderiam encaixar-se no regime do acidente, considerando que as competências modais oferecidas ao usuário têm como objetivo somente proporcionar uma exploração do espaço apresentado, não sendo possível resultar em eventos inesperados que quebrem o curso de ação.

Quanto ao regime da manipulação, aspectos sonoros e visuais do videoclipe podem orientar o usuário em sua exploração, levando-o a direcionar o enquadramento a pontos de vista específicos. Nesse sentido, a bagagem cultural do interactante ganha importância quando associamos o fazer-fazer aos elementos intertextuais do Nível Narrativo, que referenciam outras obras da banda Gorillaz, que também têm o papel de prender a atenção de certos usuários durante a navegação.

Por último, no regime do ajustamento, surge o aspecto da experiência de navegação no videoclipe, pois conforme as cenas seguem seu fluxo programado e o interactante acaba em um cenário com enquadramento por vezes aleatório são exigidas ações rápidas para que o usuário consiga seguir com a exploração do objeto. Esse aspecto por vezes pode resultar em sentimentos desconfortáveis para o interactante, como vertigem e desnorteamento, o que relaciona-se ao valor /fantasia/ da oposição de base.

\section{Conclusões}

A versão $360^{\circ}$ de Saturnz Barz enfatiza-se como imersiva e interativa ao permitir que o usuário tome controle dos enquadramentos visualizados a partir de uma perspectiva em primeira pessoa, fazendo com que sinta-se parte da narrativa. No entanto, a falta de poder sobre os acontecimentos que tomam sequência e o fluxo automatizado de cenas podem provocar desconfortos durante a experiência do interactante.

Além disso, tanto a ideia de experiência por vezes vertiginosa presente na versão interativa quanto os elementos visuais e sonoros incorporados à narrativa evidenciam que as duas versões existentes do videoclipe coexistem enfatizando aspectos mútuos. A oposição de base /fantasia/ e /realidade/ é enaltecida nesse sentido, havendo contrastes claros entre as cenas correspondentes a cada valor. 
Dessa forma, o modelo semiótico dos Regimes de Interação em conjunto da análise segundo o percurso gerativo de sentido mostram-se referenciais teóricos interessantes para compreensão de objetos como videoclipes interativos, abrindo espaço para que experiências similares possam ser construídas através dessa sequência de construção do sentido.

\section{Referências}

FIORIN, José Luiz. 2016. Elementos de análise do discurso. 15. ed. São Paulo: Contexto.

2009. Para uma definição das linguagens sincréticas. In: OLIVEIRA, A. C.; TEIXEIRA, L. (Org.). Linguagens na comunicação: desenvolvimentos de semiótica sincrética, 15-40. São Paulo: Estação das Letras e Cores.

LANDOWSKI, E. 2014. Interações arriscadas. São Paulo: Estação das Letras e Cores.

MORAN, T. 1981. "The Command Language Grammars: a represetantion for the user interface of interactive computer systems". International Journal of ManMachine Studies, 15, 3-50.

OLIVEIRA, Sandra Ramalho e. Imagem também se lê. São Paulo: Rosari, 2009.

PREECE, Jennifer, RODGERS, Yvonne, SHARP, Helen. 2002. Interaction Design. Nova Jersey: John Wiley \& Sons, Inc.

SCOZ, Murilo. Regimes de Projeto: Uma abordagem sociossemiótica do design de interação.

SCOZ, Murilo, MOTTA, Rafael Garcia. 2016. Sociossemiótica para o design de interação. Proposições interativas: modos de produzir sentidos, 29-63. Florianópolis: UDESC. 


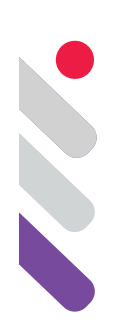

\section{Ari Folman's promises of technological mediation in The Congress}

DOI: 10.24308/IASS-2019-5-008

Cassia Cassitas

Universidade Tuiuti do Paraná, Brazil

cassiacassitas@gmail.com

\section{Introduction}

The crying eyes closed-up on in the first scene are beat upon by the low voice that insists on talking about mistakes, poor choices and past blunders. When she finally pronounces "And now...", the tears are gone - the image has revealed a woman with her back to a window where the sun, the green, the bars, and the red come together before the first cut to give time and space to the question: "What now, Albert?" It is the first time we hear the voice of the actress Robin Wright playing Robin Wright. "What did they offer?"

Albert, Harvey Keitel's character, pauses and takes a sip of his neat whiskey before continuing to ponder: "I have no idea (...). I would like to know. They called me (...), yelled at me (...), and then said they have an offer - the final offer. That this would be the last one. And that the offer wouldn't stay on the table for long".

Albert's speech, which Robin usually calls Al, introduces the disquieting and dense work. The drama is set in the co-production of Israel, Germany, Poland, Luxembourg, Belgium and France. The director is former Israeli soldier Ari Folman and his challenge is to answer the questions.

"Now" is a near future in which the movements and expressions of the actors are been scanned and the films are developed from their digital images. The offer consists of a digital work proposal for the actress Robin Wright, like everything that, in the given context, means acting.

Her agent Albert has no idea; he would like to know, but how to describe something unprecedented? John Locke once said that languages only have the words they have a need for. They don't know what they need to do.

The studio professionals called, yelled, and announced an offer. What kind of offer requires screaming? If negotiating presupposes agreements in which all parties are satisfied, what is the meaning of prior depreciation? Why 
do they believe it is necessary to lower the other party's sense of worth before making the offer?

It will be the final. The last. It will not be available for long. Is urgency a reflection of the massive use of technology? What will become of the merits of the actress of The Promised Princess (Reiner, 1988, USA), Forrest Gump (Zemeckis, 1994, USA), The Promise (Penn, 2001, USA), who led the studio to make her this offer, to justify their belief that this is the end of Robin Wright?

The answers come from Jeff Green, an incarnation of Peirce's concept of falibism, in which "sign and all I can use to lie", interpreted by Danny Huston. He looks at her directly in a dialogue as enigmatic as it is revealing: "We want to scan you. The entirety of you: your body, your face, your emotion, your smile, your tears". With her back to the camera, Robin walks down the halls of the studio as Jeff's voice continues: "We want to copy you, we want to preserve you".

At that moment, The Promised Princess poster zooms in on an image where Robin Wright's youth takes over the entire screen. "We want to own this "thing" called Robin Wright!"

On stage, the young lawyer and pragmatic: "When they make their copy and put it on the computer there is no turning back. The studio becomes the owner of the character". Robin has her doubts: "Which character?" Then he sentences, "The one the actor was."

The mediation proposal is on the table. Ari Folman is on standby to create a digital representation of Robin Wright. Digitally solve conflicts beyond truth, meet needs beyond time, and eternalize his youth beyond imagination. This study analyzes how this happens.

\section{Beyond Truth - Ambience}

Just as the character ignored the opportunities of her past, in the initial scene the landscape is presented behind Robin. Vertical frames separated Robin from the fence. Yellow flags on the left, a red flag on the right. Above, in a clear blue sky, wheels of a plane's landing gear over blurred green vegetation. In the background, an aluminum fence and in the front plane, the actress wearing dark green, light hair pulled back, hands in a silent plea over her lips.

This setting introduces the viewer to the reality of the character. Although there is life, normality and calm, she is alien to it all. She does not touch the green; neither does not feel the sun nor see the blue of the sky. The flags shake their colors vigorously, signaling landing operations that do not seem to matter to the woman without eyes for the world. All contact is made through bitter dialogue, in a tone of reckoning, with someone who will prove to be old, brown and beige, with no windows, no doors, and four lit lamps to her left. The words frame colorless pictures arranged on green, tired walls. 
A red kite in the sky without bars cuts the speech with melancholic music to, then, return to the sound Albert's silence (Harvey Keitel). "Aaron needs me back home." He speaks while a boy looks up in spite of the fence just behind him. Robin runs, dogs bark. This is the presentation, in live action, of the everyday life without future of the actress Robin Wright.

Without a doubt, the proposal is accepted, for a sequence of scenes regarding the actress' digitalization begins. Dark, the scenes displayed in a panorama around a blue "dome", full of lights surrounding the Robin Wright "thing". Here, technology talks to the image of the character to generate, together, digital representations displayed on the computer screen. The "dome" proposes to execute what Fernando Andacht calls the "Midas touch" (Andacht 2007). The attempt to represent the real of the character results in the production of pixels that refer to illusions that go beyond the captured truth. Al demands, Robin smiles, the process of capturing signs of her emotions progresses.

As the screen fades out transition in, she asks: "Can I go back to where I came from?" Twenty years have passed; she will receive honors due to the success of her character. Stimulating music insinuates itself amidst the answer. Then, she gains height amid an explosion of color in the animation in which Robin flies, drives, and comes across a statue of the young actress in a large hall predominantly pink and golden. He is filled with, if I may so call it, people in their animated versions. In the background, it should be read: "Welcome to the Futuristic Congress."

The mediation seems to work. Science fiction has given way to fantasy and life is happening in front of it. She is in the center, on the screens, at the reception asking for her room. The reality created around her representation is a success. Other contracts, what for?

\section{Beyond time - Screenwriting}

Few characters drive the dramatic structure strong and alive. The others configure the ideology of society as a frame of the time they represent. Throughout the course of the feature film, the images talk with ideas. Apparently disconnected voices and plans contribute to the effect of sinechism, "the tendency to consider everything as continuous" (CP 7.565, Peirce, 1931-1958), eliminating the dualism between biology and culture in the gender transitions of the narrative.

Image and narrative build the contradiction of superficiality to stimulate creativity. Images resemble delusions in situations that are not at all common, as if people lived in the superficiality of a sensorial dimension. By opting for the framing of characters apparently enjoying the sensations chosen, Ari Folman seems to defend the idea that the superficial unveils what really matters and 
opposes this understanding in the direct dialogues of multiple connotations of the characters. The narrative syntagma of The Congress (Folman, 2013, France) is based on the singularity of "useless details" (Barthes 2012).

At first, the drama starring the decadent actress, mother of a boy with a degenerative disease who is going deaf, turns into an exciting science fiction. After hearing from the director of Miramount "I want to keep you young forever", her indecision is placated by the cries of her agent "Wake up Robin! This is the door to your freedom!" The soundtrack brings her closer to the "dome" where she is photographed, scanned, meticulously unveiled. Like a farewell to the hopeless perspective present in her human representation, Al screams, the music screams, the problems scream. Robin succumbs and smiles.

If the script represents a transitory state, the film embodies the poetry of Jean-Claude Carrière's metaphorical definition of his "passing form destined to disappear, as the larva when it turns into a butterfly". The film is full of signs of war and other intertwined wounds, written, embedded in the work of Ari Folman. He is ready for the flight of the butterfly, which, in this case, is the transition between live action and animation.

In the trailer, the transition is sewn by the fade out after Robin Wright's question, and the answer to the character Dylan Truliner: "That place you came from doesn't exist" rocked by the song Forever Young composed by Max Richter for the film and played by Robin Wright herself. "You look fantastic! In animation, of course," says director Jeff Green when he sees it. By accepting the "final offer", everything that represents this "thing called Robin" has overcome the time barriers of time. The script links the scenes with many Robins in ontological actions and an incessant call by Aaron. Forever young! Repeat the song. Aaron! Repeat, Robin. But she wants to know, "How do I know if I'm dreaming?"

The 61st Robin registering that day, as informed by the receptionist, has sexual relations with Dylan. He holds her on the blue, on ice, they make love and meals together. Forever young higher and higher. "To find Aaron, we're going to have to go on a very long journey." The mesmerizing scenes are rosy, the lines interspersed with melody. "You make a choice and feel what you want." Aaron's kite gets lost, the present catches fire. Time's up, so is the music. The script points to the second transition. The live action drama, the animated science fiction, Dylan asks, "What will you choose?"

\section{Beyond imagination - Characterization}

Robin Wright's self-enactment (Goffman 1959) is the central argument of Folman. In a game of representing herself, in the initial live action scenes, she submits herself to the judgment of the other, to the discourse of society and finally to the digital destiny vested in the "door of freedom". I agree with Gastaldo's interpretation of Erik Goffman's words when he says that "insofar 
as relations are considered obvious - when in reality they are absolutely not - a hegemony is perpetuated. No wonder this supposed naturalness becomes a source of social constraint" (Gastaldo 2008). I add to it the feeling of rejection, supposedly unconscious, of the protagonist to the status-quo of the transactions, of the behavior they expect of her. If Al configures the fatigue of her past, Jeff Green waves with the surety of a future. But she seems to insist on denaturalizing what for others is natural. After all, who is Robin Wright, anyway? The sequences explore her relationship with the world, her feelings, her needs, until she reaches the point in the film where she meets Dylan's animated version and can choose.

Andacht states that "when the audience observes the expressions of emotions of ordinary people that they consider not to be scripted or rehearsed, and, therefore, spontaneous behavior, close to the physiological - exactly the opposite of what happens in fiction - spectators yearn to experience of authenticity" (Andacht 2015). I appropriate his statement to analyze Robin Wright's choice as object and sign. Augmented reality interacts with the world. All Robin had to do was take the ampoule for her perception of reality to transform. Unlike virtual reality that reports to another world through glasses or special clothes, there is no departure. Consequently, there is no return. The access is by one's own body, mind and will. Amid the realm of presumed will, what leads her to differ from the almost unanimous choice of people to adhere to this representation of the world provided by augmented reality? If it is human nature to seek satisfaction and pleasure, what could be more real than to cling to mechanisms to realize one's own will and the satisfaction of their physiological needs? However, she insists on slipping out of script.

The characters in the animation scenes contrast with the people who suffered from the first live action sequences. The images are full of signs of need. In contrast, in the animation there are signs of exuberance. Starting from the fictional context of the actress who plays herself, what better example of a genuine relationship between object and the sign that represents it could we find (CP 2.92, Peirce, 1931-1958)? Robin presents herself with her chronological age, her slender body, and her deep eyes. Would, in final analysis, the possibility of self-representation have freed people from the need of others' approval? On the other hand, would Robin be incapable of assuming herself in another perspective, as she had in the past, by giving up productions and breaking contracts?

Ari Folman displays the mechanisms of technological mediation and presents Robin with loving possibilities, adventures, a privileged place in the digital society that her images helped build. In intelligent dialogues, she gives clues of the latent conflicts under the brightly colored "the futuristic congress" beyond her imagination to which she was invited. Through studio resources, 
she breaks through the boundaries of genres in audiovisuals and puts Robin Wright the person-actress-personage in search of what moves her, always has and digitalization has not changed: Aaron. The fundamental sign of the representation of the real in Robin is the feeling for her disabled son.

\section{Conclusion}

Robin's index appeal (Andacht 2015) reverberates in the multicultural context of the film The Congress (Folman, 2013, France). Culture consists of the semiotic perspiration of a people. Motherhood, disability, care for the other are of the order of the "qualities belonging to the natural and undeniable mode of the sign considered in itself". This sign is seen in the light of Folman's trajectory, an ideal of humanity that he pursued in the representation of the real through alternative bodies, lives and worlds.

Through the ingestion of a chemical compound to establish the dialogue between art and technology, Ari Folman opts for setting in the human body the representation of reality. Therein lies the truth of feelings and will, expressed, in my opinion appropriately, in psychedelic imagery. After all, we are talking about a mediation of the effect of symbols with the objective, in my opinion, of cognitive transfiguration of those who are caught in the narrative mesh (Andacht 2012). If aesthetic passion reflects the fear of reality, the transitions in the film script suggest a mediation bias. As an experiment in language, it adopted hybridism to construct sensory delirium and make the "real" technological, pure, simple, and intelligible.

Augmented reality presupposes the expanded perception of elements by individuals who, when projecting themselves before the eyes of others, reveal themselves in their preferences. And the visibility, in my opinion, provided by the augmented reality in a utilitarian way, reflects the desire of humanity to be seen. From Belgium to Poland, from Israel to France, people want to participate in the spectacle, even if only in the triviality of its routines (Marquioni and Andacht 2016), or even in the bizarre self-image chosen by people. The narrative constructs the reality of the character who travels to contaminate himself with otherness.

To run or to fly, the affliction motivates the movement. The anguish of uncontrollability accompanies the protagonist in the transience of her journey through drama, through science fiction, in a wander through places full of people and empty of answers. She neither answers the questions in live action nor feeds her identity in a flow of signification. Without will, technological mediation proves innocuous. More than a liberation from the eyes of others, her animated image reflects its inanition before opportunity.

Despite the proliferation of quality signs, or iconic ones, and factual, or indicative ones, Robin does not reach the aesthetic moment in which she could 
wake up, have a keen perception, feel the taste of life. Happiness and sadness defined in colors, shapes and behaviors. Technology permits one to suppress tears and represent feelings in behaviors such as jumps and distortions. How can we say that these representations are less appropriate, if technology only mediated the option preferred by many individuals?

The semiotic mediation of technology shows itself to be efficient on screen and ineffective on the actress. She prefers the promise of reunion in the desolation left behind. Considering Peirce's definition of representation, everything that is present before us is a phenomenal manifestation of ourselves. In the rigor of Robin Wright's script, motherhood surpasses the actress and the woman. It anesthetizes her imagination, consumes her time and reveals itself as her truest representation.

\section{REFERENCES}

ANDACHT, Fernando. 2007. Os signos do real no cinema de Eduardo Coutinho. Devires. Cinema e Humanidades v. 4, n. 2, p. 42-61.

ANDACHT, Fernando. 2015. Uma abordagem semiótica e indicial da identidade na era de Youtube. UFRGS Intexto n. 34, p. 79-98.

ANDACHT, Fernando. 2012. Jogo de Cena ou a cena da mediação semiótica observada em um palco filmado. Libero v. 15, n. 30, p. 69-86.

BARTHES, Roland. 2012. O rumor da língua. São Paulo: Martins Fontes.

GASTALDO, Edison. 2008. Goffman e as relações de poder na vida cotidiana. Revista Brasileira de Ciencias Sociais vol.23, n.68, pp.149-153.

GOFFMAN, Erik. 1959. The presentation of self in everyday life. Doubleday AnchorBooks.

MARQUIONI, Carlos Eduardo and ANDACHT, Fernando. 2016. Jogando com a comida: MasterChef e os recursos televisuais que tornam espetacular uma atividade ordinária. E-Compos v.19, n. 2, maio/agosto.

PEIRCE, C. S. (1931-1958). The Collected Papers of C. S. Peirce. C. Hartshome, $p$. Weiss \&A. Burks (eds.). Harvard University Press. 


\title{
A transmídia como semiosfera para a construção estética
}

DOI: 10.24308/IASS-2019-5-009

\author{
Gisele Frederico \\ Universidade de São Paulo, Brasil \\ gisele.frederico@usp.br
}

\section{Introdução}

Este artigo é resultado de parte dos meus estudos desenvolvidos durante o mestrado, que resultou na publicação da dissertação $A$ modelização na construção estética do sistema transmídia The Walking Dead ${ }^{1}$. O objetivo deste artigo é refletirsobre como a semiótica da cultura pode nos ajudar a compreender as potencialidades estéticas ao pensarmos na estruturalidade do sistema transmídia.

Em fins do século $X X$, a informação passou a ser um produto de extensa comercialização com o desenvolvimento de novas tecnologias, e o estabelecimento da convergência digital como novo paradigma comunicacional, artístico e de distribuição. Nesse contexto, a narrativa ficcional precisou se adaptar e buscar as ferramentas necessárias para contar histórias a um consumidor de produtos culturais cada vez mais engajado e participativo.

Simultaneamente, vimos o surgimento de obras digitais multimídia, que revelaram processos de concomitância e hibridização entre tecnologias, efeitos, meios, códigos e linguagens (Bairon 1995). Nesse contexto, novas estratégias de comunicação e distribuição, denominadas crossmídia, surgirama partir da veiculação de um mesmo conteúdo narrativo em diferentes plataformas e mídias.

O desenvolvimento das narrativas transmídia surgiu como uma evolução, e consequência óbvia, das campanhas crossmídia. O espectador-usuário, inserido no contexto da convergência digital, viu-se insatisfeito em consumir o mesmo conteúdo em diferentes mídias. Ele queria mais, queria mergulhar em um universo com potencial narrativo infinito. Uma obra transmídia, seja ela

\footnotetext{
${ }^{1}$ https://teses.usp.br/teses/disponiveis/27/27161/tde-27122018-103310/pt-br.php (último acesso: 20 de janeiro de 2020).
} 
de cunho artístico ou publicitário, é aquela que explora diferentes plataformas e mídias, as quais se relacionam e formam uma rede em que o espectadorusuário pode navegar por todo universo narrativo.

Elaboreiminha proposta de pesquisa a partir do entendimento de que a concepção estética de um projeto transmídia está disseminada em todos os meios do sistema. Isto é, a narrativa não é o único elemento que amarra todas as mídias. Cada artista envolvido na produção de um fragmento narrativo, independentemente do meio, seguirá parâmetros estéticos já definidos para o sistema. A opção pela semiótica da cultura como ferramental teórico decorre de seu caráter estrutural, que nos ajuda a estabelecer e compreender cada etapa do processo de construção da conformidade estética do sistema transmídia.

A seguir, argumentarei como as potencialidades estéticas de uma narrativa transmídia se expandem quando saímos dos diagramas tradicionais, pautados na narrativa, para olharmos a dinâmica transmídia como um espaço de traduções entre diferentes linguagens, como a semiosfera.

\section{A transmídia como semiosfera}

Uma obra transmídia ideal é aquela em que cada meio é uma contribuição valiosa ao todo e não há redundância narrativa. Cada mídia deve ser uma porta de entrada autônoma à obra, sem que invalide as demais, no caso de algum espectador-usuário deixar de consumir algum fragmento da história. Uma pessoa que assiste ao filme e lê os quadrinhos, mas não joga o videogame, deve compreender perfeitamente as mensagens dos meios com os quais entrou em contato.Boa parte da audiência de uma obra transmídia não acessará todas as mídias do sistema, daí a necessidade de cada meio ser parte de um todo e, ao mesmo tempo, autossuficiente.A narrativa transmídia integra mídias tradicionais (livros, quadrinhos, cinema e televisão) e as mídias interativas (videogames, aplicativos, vídeos de realidade virtual), e é característica de uma geração de produtores que cresceu como gamers e que quer explorar o potencial narrativo desses meios (Jenkins 2009). A seguir, vemos o diagrama tradicional que representa uma obra transmídia a partir das relações entre os fragmentos narrativos e as mídias envolvidas. 
Figura 1 - O que é transmídia?

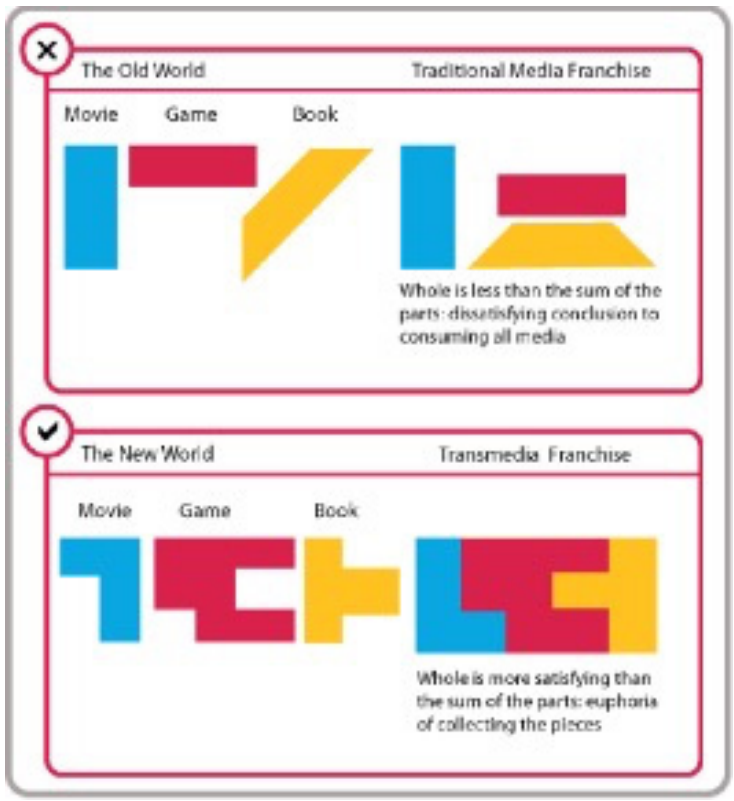

PRATTEN, Robert. Getting started with transmedia storytelling: a practical guide for beginners.2. ed. Creatspace, 2011.

luri Lotman - semioticistas da escola de Tártu-Moscou - elaborou a teoria e cunhou o termo semiosfera, que se refere ao continuum semiótico, fora do qual é impossível a existência da semiose. Isto é, comporta-se como "um ambiente no qual diversas formações semióticas se encontram imersas em diálogo constante, um espaço-tempo, cuja existência antecede tais formações e viabiliza o seu funcionamento, enquanto torna possível o seu próprio ciclo vital" (RAMOS et al. 2007: 34). À semiosfera é necessária a autoconsciência de sua especificidade para a formação da cultura. $E$, a sua fronteira é o ponto de tradução e contaminação entre o que é organizado e sistematizado em uma cultura e o que não lhe pertence.

Além de identificar a singularidade da semiosfera, Lotman (1996) também propôs um modelo para sua organização interna. Segundo ele, "o espaço semiótico caracteriza-se pela presença de estruturas nucleares (variadas) com uma organização evidente e um mundo semiótico mais amorfo que tende para a periferia, em que as estruturas nucleares estão submersas" (Lotman 1996: $29)^{2}$. As diferentes linguagens estão submersas no espaço semiótico de maneira heterogênea, uma vez que as estruturas nucleares têm menor potencial de tradução e de gerar novas informações se comparadas às estruturas que se encontram próximas à fronteira.

Para a Escola de Tártu-Moscou, uma linguagem é uma abstração de

2 "El espacio semiótico se caracteriza por la presencia de estructuras nucleares (con más frecuencia varias) con una organización manifiesta y de un mundo semiótico más amorfo que tiende hacia la periferia, en el cual están sumergidas las estructuras nucleares." 
códigos que tem sua existência materializada no texto semiótico - realização de um sistema que pressupõe a existência de uma não-organização externa, evidenciando seu caráter delimitado. Um idioma, por exemplo, é um código que admite a existência de elementos que não o integram, mas que podem ser parte de outro sistema organizado. E, para analisar tal código, é preciso partir de um texto escrito ou de uma fala. Como dissemos anteriormente, essa fronteira,entre o que é sistematizado e o que não é, define a individualidade semiótica da semiosfera, das linguagens que nela estão imersas, e dos textos semióticos produzidos dentro da cultura.

Ao propor a aproximação entre os conceitos de transmídia e semiosfera, fui compelida a definir as relações existentes entre plataforma, mídia, meio e linguagem.(1) Plataforma é o conjunto de códigos e parâmetros de produção e veiculação de conteúdos que sustenta uma tecnologia. Uma obra multimídia composta por quadrinhos, radionovela e aplicativo de smartphone foi necessariamente construída sobre três plataformas distintas: impressa, radiodifusão e telecomunicação móvel. É importante lembrar que os termos multimídia e multiplataforma não são sinônimos, ainda que muitas vezes se confundam.(2) Lisa Gitelman (2006) explora o conceito de mídia como sendo a combinação da tecnologia e de seus protocolos associados, que são práticas sociais desenvolvidas em torno da tecnologia e que se tornam invisíveis aos usuários com o passar do tempo. (3) Optei por trabalhar com o conceito de meio desenvolvido por Marshall McLuhan, para quem o meio é como uma extensão de nós mesmos, que gera um novo padrão comportamental como consequência social a partir da introdução de uma nova tecnologia. O meio não é apenas um veículo para um conteúdo, "'o meio é a mensagem', porque é o meio que configura e controla a proporção e a forma das ações e associações humanas" (McLuhan 2016: 23).

A partir do cruzamento entre as ideias de McLuhan e luri Lotman, cheguei ao ponto crucial de minha pesquisa em que pudeolhar para a construção estética de um sistema transmídia a partir das relações entre as diferentes linguagens que o constituem. Para isso, (4) considerei a linguagemcomo um sistema que serve à comunicação por meio de regras estruturais de combinação de signos. Isto é, linguagem e meio estão, necessariamente, associados e a mensagem está integrada à linguagem. Portanto, não há arbitrariedade no conteúdo designado a determinado meio em uma obra transmídia, uma vez que, além da mensagem informativa, "os sistemas artísticos também podem incluir informações sobre sua própria linguagem" (Lotman 1998: 242) ${ }^{3}$. A arte reflete sua semântica e sintaxe de uma só vez.

3 "Los sistemas artísticos pueden encerrar información también sobre el lenguaje mismo." 
Assim como as linguagens, os meios que compõem um sistema transmídia têm estruturalidade própria, o que determina o fragmento narrativo que será explorado por cada um. Essa estruturalidade é isomórfica à semiosfera. E, esse entendimento éessencial para a minha proposta de aproximação entre a estrutura do sistema transmídia e da semiosfera. A heterogeneidade intrínseca da semiosfera cria estruturas textuais isomorfas. Isto é, os textos estão fechados em si mesmos, apresentam fronteiras de contato e estruturas nucleares com menor nível de tradução. As estruturas isomorfas, ao se tocarem e relacionarem, criam novas informações e textos, os quais habitam e enriquecem a semiosfera analisada.

Para assimilar e interagir dentro de um sistema narrativo transmídia, a audiência precisa estar imersa na semiosfera cultural do século XXI, em que a semiose entre as mídias adquire uma característica de convergência. O espectador-usuário do século XXI está adaptado à velocidade com que as mídias se transformam e surgem em diversas plataformas, sobretudo nas digitais. As obras transmídia estão imersas na semiosfera da convergência, enquanto que os meios estão imersos no sistema transmídia. Portanto, pode-se afirmar que existe uma relação de isomorfia entre a semiosfera, o sistema transmídia e as linguagens que o compõem.

Figura 2 - Isomorfismo

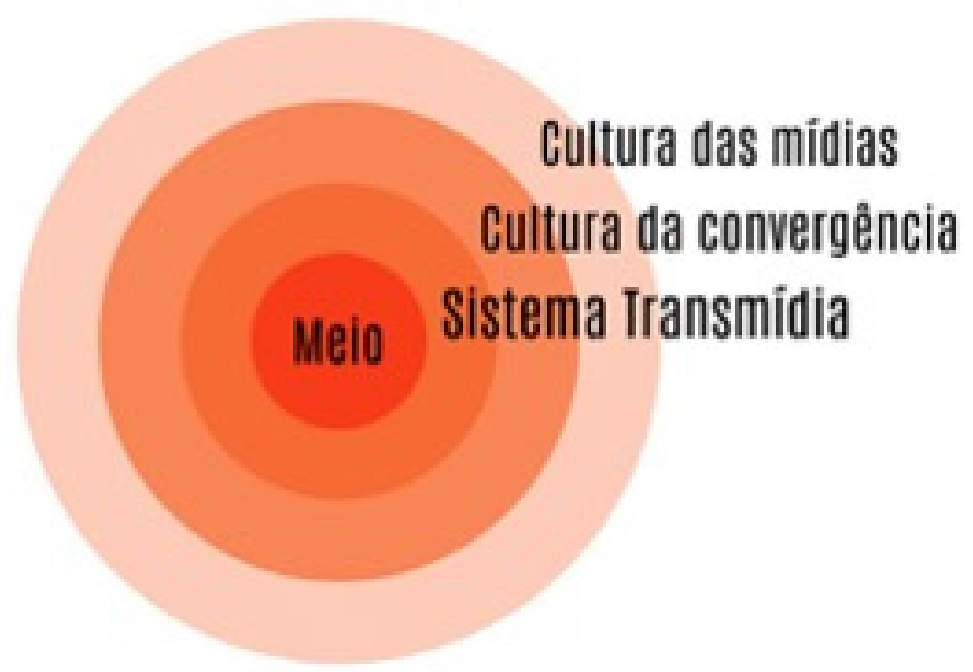

O sistema transmídia ideal concilia diversos meios, mas não os organiza rigidamente, já que o espectador pode optar entrar no sistema pela mídia que melhor lhe convém. No entanto, é comum que o sistema tenha um meio que o notabilize e atraia novos espectadores-usuários. Esse meio concentra as 
potencialidades narrativas a serem expandidas, bem como as características estéticas que serão replicadas em todas as mídias. Ele está no centro do sistema e, como o centro da semiosfera, suas estruturas são menos mutáveis no processo de expansão do sistema.

Nossa proposta não é estabelecer uma análise dos elementos mais simples que compõem uma estrutura mais complexa, mas tentar identificar a correspondência estrutural entre a semiosfera da cultura das mídias do século XXI e um dos produtos da semiose que ocorre em seu interior: o sistema transmídia. Não se trata de um todo formado por partes, mas de estruturas absolutas e similares que se encaixam uma dentro da outra.

\section{A modelização na construção estética}

A consciência humana é uma consciência linguística, pois a língua natural exerce influência no psiquismo dos indivíduos, o que configura a linguagem verbal como um sistema de modelização primário. Consequentemente, todos os modelos, isto é, estruturas sobrepostas à consciência são definidos, pela escola de Tártu-Moscou, como sistemas modelizantes secundários. Assim sendo, podemos dizer que todas as linguagens e códigos artísticos são de modelização secundária.

Os estudiosos da semiótica da cultura buscaram na informática a base para o novo termo: modelização. A modelagem é um processo cognitivo que produz modelos a partir de fenômenos reais, especificando as estruturas e criando uma representação simplificada e replicável. Em outras palavras, modelização é a operação que organiza e controla os elementos e as etapas de um processo de comunicação, que não seria possível sem a sistematização do que antes estava disperso.Toda cultura gera um modelo cultural próprio, em razão disso, a modelização atua como geradora e replicadora de comportamentos e códigos culturais, "que atuam como representantes, elementos de identidade e geradores de significação. Dessa forma, a modelização é, então, tradução, passagem, transferência, transformação da informação em mensagem, em signo"(Almas 2013: 186).

Demonstrada a isomorfia entre a cultura das mídias, a convergência digital, o sistema transmídia e os meios, defendo que algumas características estéticas nucleares da narrativa transmídia são modelizadas por todo o sistema rumo à área fronteiriça. Nesse processo, os textos semióticos - materialização das linguagens submersas no sistema - comunicam-se, geram novos textos estéticos e alimentam o sistema. Posto que a informação estética é sempre inseparável de sua realização e não pode ser traduzida ou descrita por outro código que não o da obra original, esse intercâmbio entre as diferentes linguagens é parte da consciência criadora e alimenta o sistema em que elas estão inseridas. 
A obra de arte não é a materialização de apenas uma linguagem, ela é o resultado da interação de textos semióticos com origem em diversas linguagens. O processo de significação emerge da interação desses textos estéticos, que se modelizam e carregam signos que geram sentidos e sensações similares nos diversos meios.Em The Walking Dead (TWD), que compõe meu corpus de pesquisa, pude identificar diversos textos semióticos que se modelizaram por todo o sistemaa partir dos quadrinhos e da série televisiva.

\subsection{A modelização em The Walking Dead (TWD)}

Em 2003, o escritor Robert Kirkman e o quadrinista Tony Moore lançaram a revista em quadrinhos (HQ) TheWalkingDead, ambientada em um mundo pós-apocalíptico tomado por zumbis. Em 2009, a emissora de TV norteamericana AMC comprou os direitos de produção e veiculação, e uma série televisiva (broadcasting) foi lançada em 2010. A série se tornou um grande sucesso mundial e, então, novas mídias e novas narrativas foram agregadas a esse universo, fazendo com queThe Walking Dead se tornasse um vasto sistema transmídia.

Identifiquei os textos semióticos que se modelizam por todo o sistema a partir da tradução dos quadrinhos para a série televisiva, já que esses são os meios que se encontram no núcleo do sistema, com características mais estáveis.

Para este artigo, optei por focar meus esforços nos quadrinhos, na série televisiva, nos videogames The Walking Dead, da Telltale Games, The Walking Dead: Survival Instinct, da Terminal Reality, e a web serie veiculada no site da AMC e no YouTube. E, por questões de organização, dividi os textos semióticos em três categorias criadas a partir do código cinematográfico:

a) Decupagem ${ }^{4}$ :

Os planose enquadramentos do sistema transmídia de TWD derivam dalinguagem cinematográfica clássica,identificadas na semiose entre quadrinhos - linguagem original - e a série televisiva - peça de maior sucesso midiático.Ambas estão no centro do sistema transmídia de The Walking Dead e o contato entre elas gerou muitos textos semióticos que foram modelizados por todo o sistema, criando uma homogeneidade estética em TWD, e não apenas narrativa.O primeiro exemplo de texto semiótico modelizante identificado é a relação entre o espaço in e o espaço off. A tensão gerada pelos seis limites do campo da imagem ${ }^{5}$ está presente em todas as linguagens, seja ela gráfica,

\footnotetext{
${ }^{4}$ Processo no qual a cena cinematográfica é divida em planos, que são as unidades mínimas do filme.

${ }^{5}$ Os quatro limites laterais do quadro mais o fundo da imagem (atrás do cenário) e o limite atrás da câmera.
} 
audiovisual, interativa ou não. O limite entre o espaço do quadro e fora dele é construído por sombras e pela manipulação da profundidade de campo. As sombras e o cenário composto por vários objetos em profundidade modelizam todo o sistema transmídia para a construção de um clima de tensão permanente na narrativa.

\section{Figura 3 - Espaço in x Espaço off}
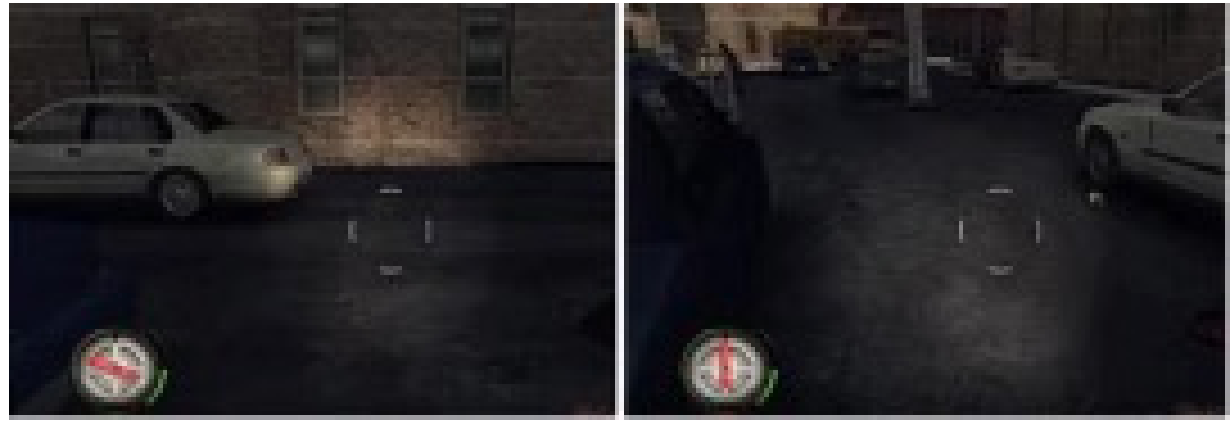

Fonte: The Walking Dead: Survival Instinct, Terminal Reality

Figura 4 - Objetos em profundidade de campo multiplicando a tensão entre os espaços dentro e fora do quadro.

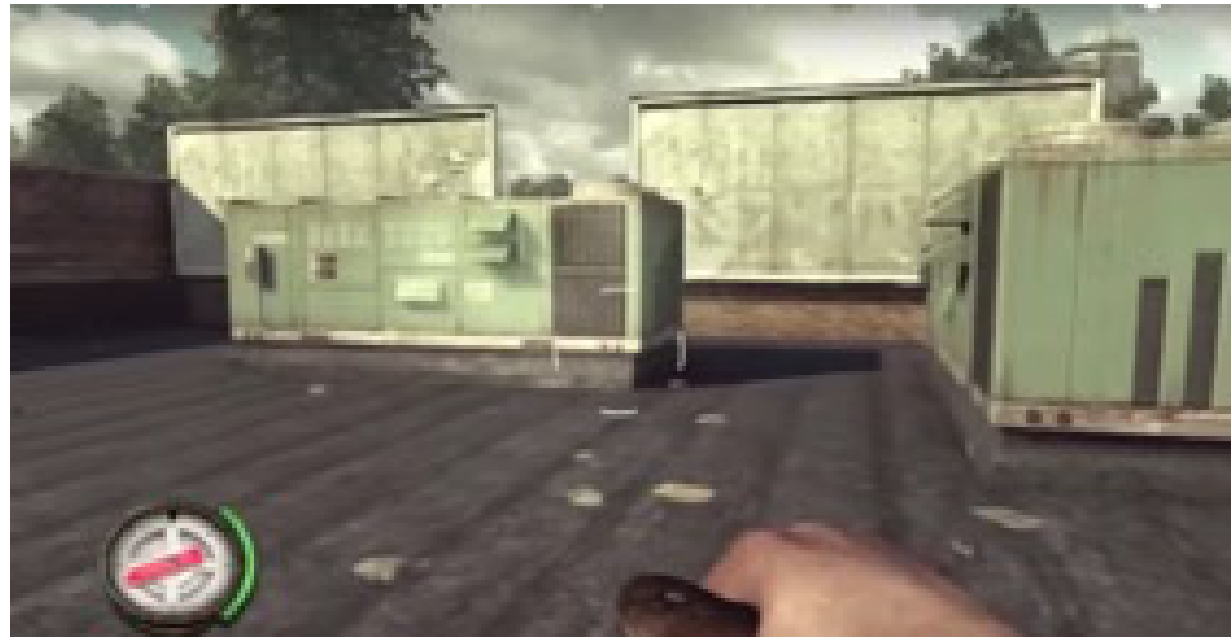

Fonte: The Walking Dead: Survival Instinct, Terminal Reality

Outro texto semiótico modelizante que ajuda a construir a estética de toda a narrativa transmídia do universo de zumbis é areferência da arma como plano subjetivo ou over-the-shoulder.Esse segundo tipo de plano, comum na decupagem clássica cinematográfica, é usado quando o objetivo do diretor é 
colocar o espectador o mais próximo possível da perspectiva do personagem, ao mesmo tempo em que mantém a câmera em terceira pessoa, garantindo o olhar privilegiado do espectador.O plano com referência da arma, especialmente o over-the-shoulder, deu origem a dois novos planos modelizantes para o sistema transmídia: o plano subjetivo que vê o zumbi se aproximando, e o contra-plano que vê o personagem empunhando a arma.

Figura 5 - Planos com referência das armas
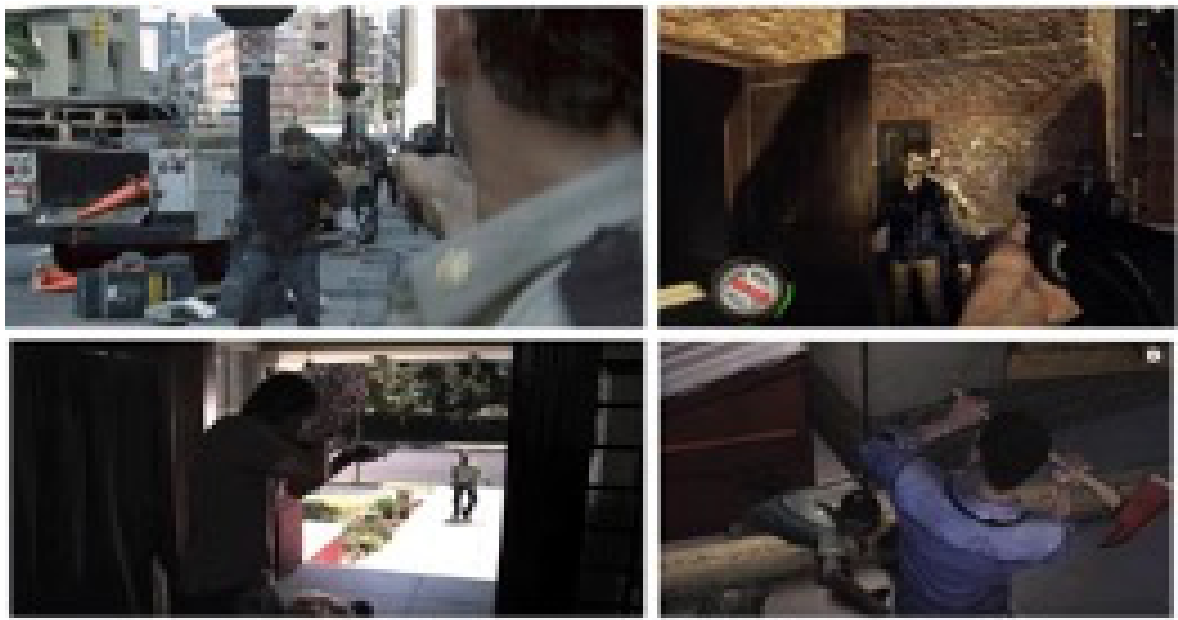

Fonte: The Walking Dead: 1a temporada, episódio 02; The Walking Dead:

Survival Instinct; The Walking Dead: A New Day; The Walking Dead, Telltale Games, 1a temporada, episódio 01

Figura 6 - Contra-plano de personagem segurando a arma

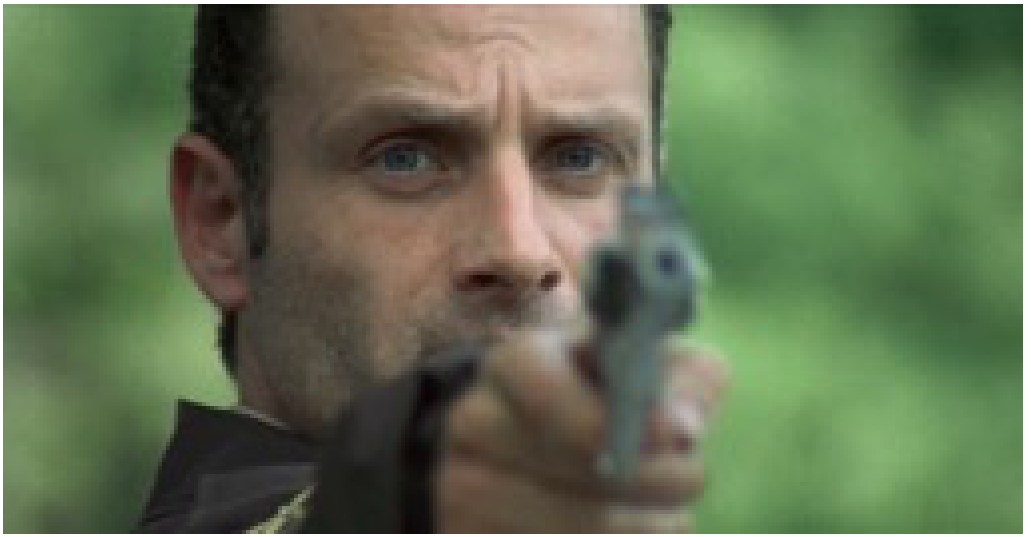

Fonte: The Walking Dead: 1a temporada, episódio 01. 
b) Fotografia:

Além da decupagem e da composição dos quadros, no processo de tradução a partir da $\mathrm{HQ}$, os criadores da série televisiva fizeram algumas escolhas relacionadas à textura e à cor da imagem, e o resultado foi uma imagem final bastante granulada, com pouca saturação e cores mais frias. Essas escolhas pretendiam transcodificar os traços da linguagem gráfica dos quadrinhos para a linguagem audiovisual da série liveaction.

A decodificação mental da textura visual é muito específica e de difícil tradução. The Walking Dead é um seriado que optou por ser filmado primordialmente em película $16 \mathrm{~mm}$, usando o formato de super 16 , a fim de manter as proporções de altura e largura (aspect ratio) semelhante ao HD (high definition). ${ }^{6}$ A imagem do negativo $16 \mathrm{~mm}$ é granulada, o que lhe confere um aspecto mais denso e palpável, como uma revista em quadrinhos.

Após o grande sucesso da série televisiva, conforme os demais meios foram sendo agregados ao sistema, essas características relacionadas à fotografia da imagem audiovisual foram modelizadas, criando uma homogeneidade estética em todo o universo transmídia.

Figura 7 - Rick chega em Atlanta.

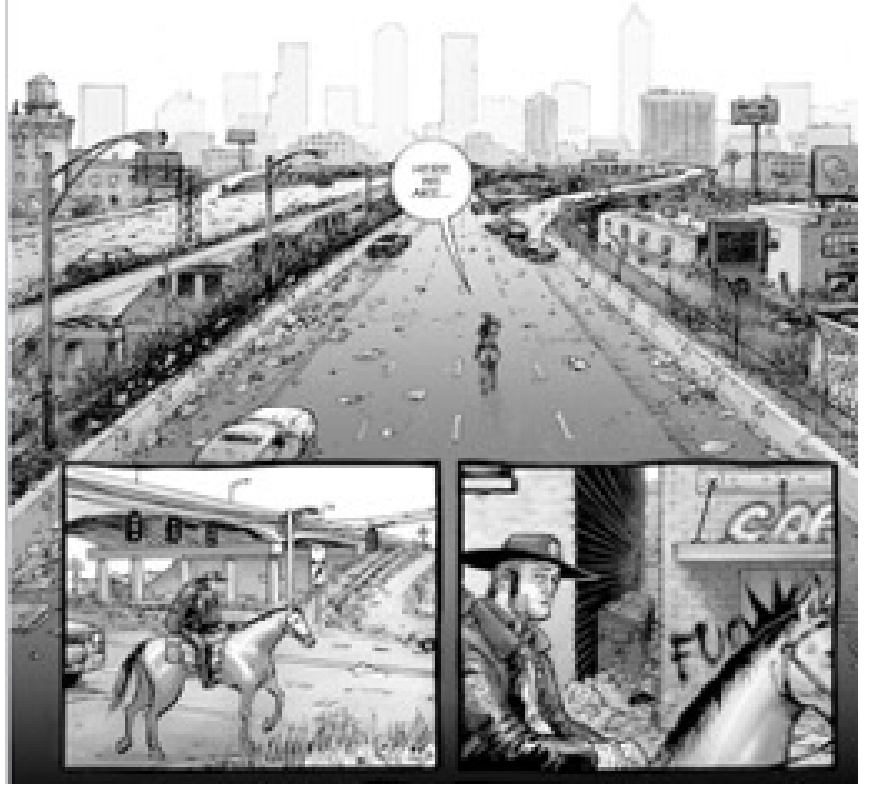

Fonte: The Walking

Dead. v. 01, n. 02

\footnotetext{
${ }^{6}$ Dados técnicos das câmeras e negativos utilizados na série: <http://www.imdb.com/title/ tt1520211/technical?ref_=tt_dt_spec>. Acesso em: 04mar. 2020.
} 
Figura 8 - Transcodificação do enquadramento, textura e cores frias dos quadrinhos para a série televisiva.
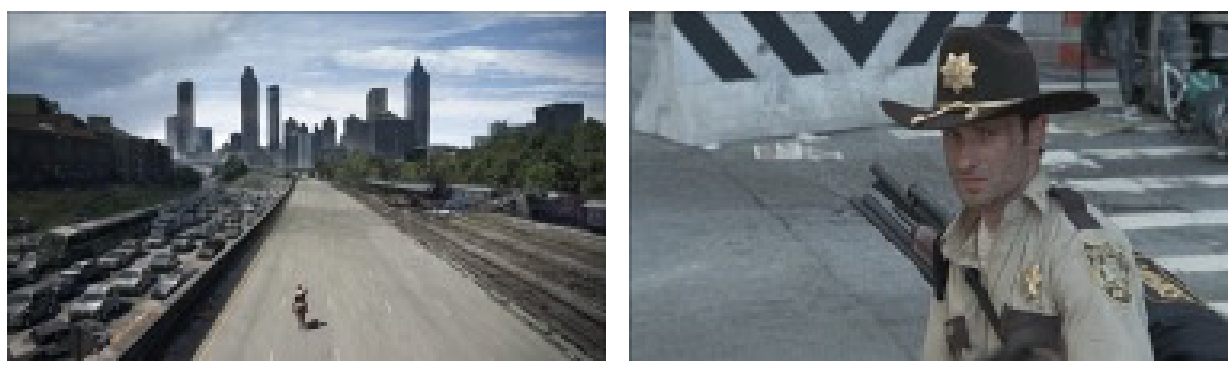

Fonte:The Walking Dead: 1a temporada, episódio 01

O código gráfico dos quadrinhos trabalha com a representação de focos de luz, responsáveis por criar sombreamento e volume de forma verossímil. Os quadrinhos de The Walking Dead foram concebidos para serem em preto e branco, tornando o contraste entre áreas claras e escuras essencial para a construção das formas, volume e para a progressão da narrativa. Os quadrinhos exploram cantos escuros e pontos de luz, como fogueiras, para criar tensão. Na série, novamente vemos a transcodificação dessa construção visual na manipulação fotográfica.Na "figura 3" acima, vemos a mesma característica modelizada no videogame The Walking Dead: Survival Instinct, da Terminal Reality, quando a luz da lanterna determina diegeticamente o contraste entre as áreas iluminadas e as escuras. Nas figuras a seguir, veremos que não apenas fontes de luz primárias, como o fogo, mas também secundárias, que refletem a luz de outra fonte, são largamente usadas nos quadrinhos e na série para manter a verossimilhança.

Figura 09- Contraste entre luz e sombra nos quadrinhos.

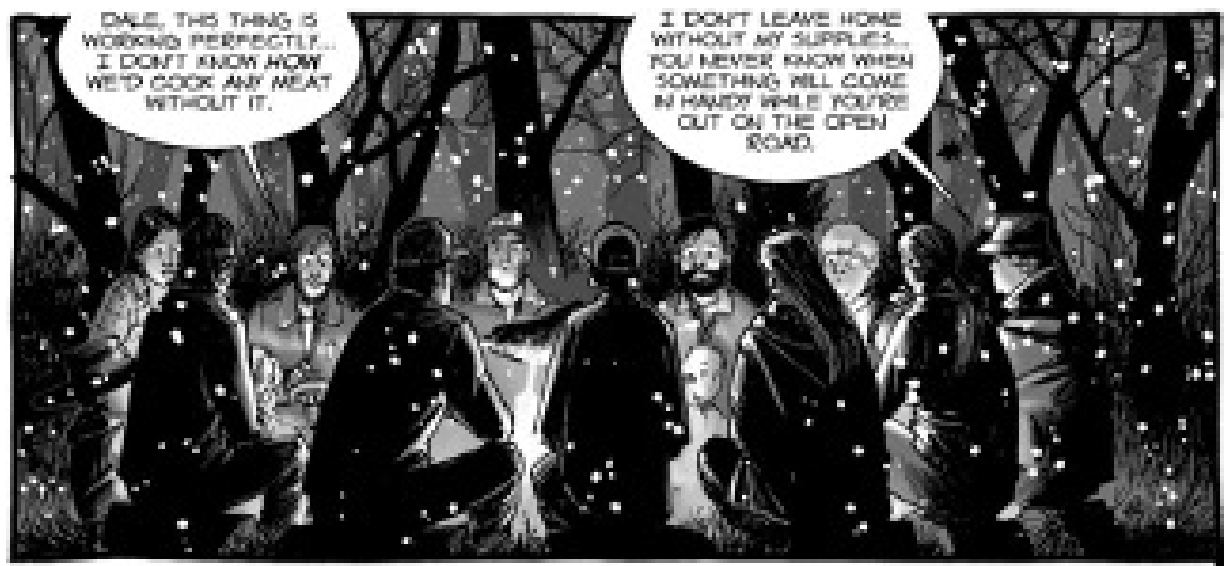

Fonte: The Walking Dead. v. 01, n. 05 
Figura 10 - Contraste entre luz e sombra na série televisiva.

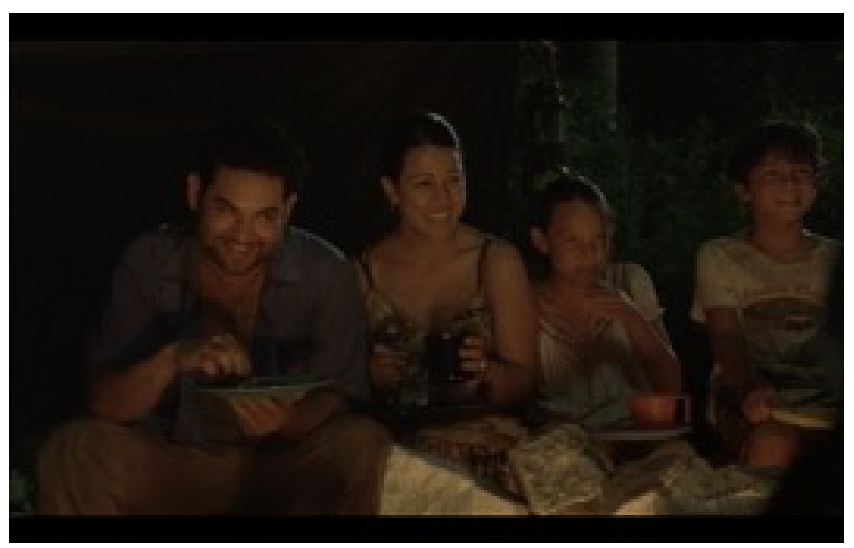

Fonte: The Walking

Dead: 1 a temporada, episódio 04

c) Montagem:

O contato entre o código dos quadrinhos e o cinematográfico gerou um processo de tradução do raccord cinematográfico que foi modelizado por todo o sistema transmídia de The Walking Dead. O raccord é um elemento que permeia tanto a decupagem quanto a montagem, pois está presente na elaboração do plano de filmagem e na edição, que encadeia os planos segundo os códigos da imersão. Sobre o raccord,Noël Burch (2015: 30) diz:

Quando, entre 1905 e 1920, os diretores de cinema começaram a aproximar suas câmeras das personagens, a decupar fragmentos no espaço do proscênio teatral, que foi o do cinema primitivo, eles perceberam que, se quisessem preservar a ilusão de um espaço teatral (espaço real, imediato e constantemente compreensível) - pois este era o objetivo e, para muitos, ainda é -, deveriam observar certas regras para que o espectador não se perdesse, nem ficasse privado desse sentido de orientação que ele experimenta diante da cena teatral (e, talvez diante das 'cenas' da vida). Foi assim que nasceram as noções de raccord de direção, de olhar e de posição.

A web serie, por seguir os preceitos do cinema clássico, também respeita o raccord tanto na elaboração da decupagem quanto na edição do vídeo. A plataforma de exibição muda, mas a linguagem se mantém. A montagem, juntamente com a decupagem, pretende suavizar a descontinuidade característica das produções cinematográficas. A web serieThe Walking Dead: A New Dayadota esse recurso em todas as suas narrativas, evidenciando a modelização dos procedimentos da montagem clássica, como a progressão dos enquadramentos, que se tornam cada vez mais próximos ou mais abertos, nunca pulando drasticamente de um plano geral para um plano detalhe; o respeito ao eixo de gravação no encadeamento dos planos; a alternância dos planos respeitando o olhar do personagem etc. 
Figura 11 - Montagem da web serie respeitando o raccord cinematográfico.
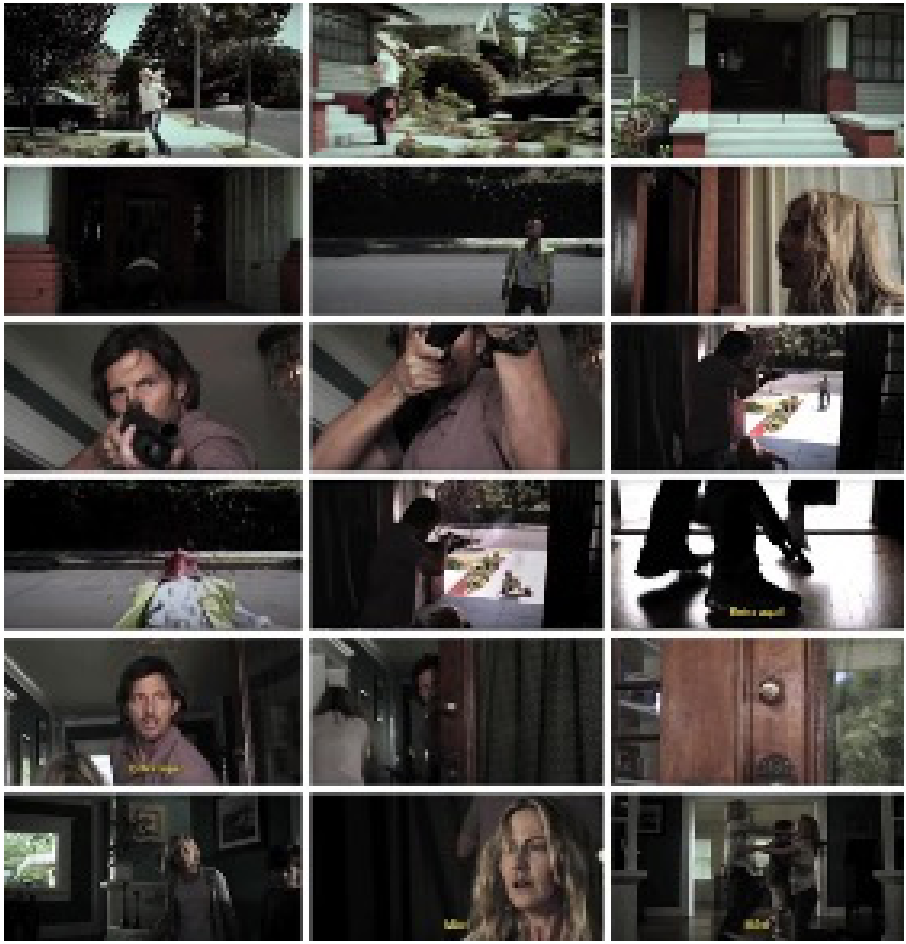

Fonte: Web

serieThe Walking

Dead: A New Day

\section{Considerações finais}

Este artigo é fruto de parte dos meus esforços de pesquisa que deram origem à dissertação $A$ modelização na construção estética do sistema transmídia The Walking Dead (2018), e teve como objetivo demonstrar que a semiótica da cultura pode ser um elemento essencial para a análise estética de um sistema transmídia, se o considerarmos como espaço de diálogo e troca sígnica entre as diferentes linguagens que o compõe.

A partir da comparação entre a estrutura da semiosfera e dos sistemas transmídia, pude compreender como se dá o diálogo entre as diferentes estruturas sígnicas que compõem a estética de uma obra transmídia. Elas não são estabelecidas aleatoriamente, são fruto da semiose entre as diversas linguagens que compõem o sistema. Portanto, a identidade estética de uma obra desse tipo é fruto dos textos semióticos de matriz modelizante gerados nesse contatoentre os códigos que atuam em todo o sistema. A literatura sobre obras transmídia muitas vezes se limita a temas como a construção do universo narrativo ou às estratégias comerciais de distribuição. O primeiro desafio da minha pesquisa, portanto, foi suplantar tais abordagens, para que pudesse olhar apenas para a construção estética de um sistema transmídia. 


\section{Referências bibliográficas}

ALMAS, Almir.2013.Televisão digital terrestre: Sistemas, padrões e modelos. São Paulo: Alameda.

BAIRON, Sérgio. 1995. Multimídia. São Paulo: Global Editora.

BURCH, Noël. 2015 [1969]. Práxis do cinema, 2nd edn. São Paulo: Perspectiva.

GILTELMAN, Lisa. 2006. Always already new: Media, history, and the data of culture. Cambridge: MIT Press.

JENKINS, Henry. 2009[2006]. A cultura da convergência, 2ndedn. São Paulo: Aleph.

LOTMAN, luri. 1996. La semiosfera I: Semiótica de la cultura y del texto. Tradução Desiderio Navarro. Madri: Ediciones Cátedra.

1998. La semiosfera II: Semiótica de la cultura, del texto, de laconducta y delespacio. Tradução Desiderio Navarro. Madri: Ediciones Cátedra.

MCLUHAN, Marshall. 2016 [1969]. Os meios de comunicação como extensões do homem. 1. ed., 19a reimpressão. São Paulo: Pensamento-Cultrix Ltda.

RAMOS, Adriana V. et al. 2007. Semiosfera: exploração conceitual nos estudos semióticos da cultura. In: Irene MACHADO (eds.), Semiótica da cultura e semiosfera. São Paulo: Annablume\& Fapesp. 


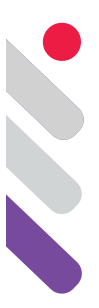

\section{Configuraciones discursivas de la crítica cinematográfica en youtube}

DOI: 10.24308/IASS-2019-5-010

Laura Andrea Iribarren

Facultad de Ciencias Sociales, Universidad de Buenos Aires, Argentina

laurairi@hotmail.com

\section{Introducción: la crítica de cine y el desarrollo de Youtube}

La crítica de cine es una práctica discursiva que se ha desarrollado en Francia en la década de los '50 en "Cahiers du Cinema". André Bazin, Jean-Luc Godard, François Trauffaut o Enrich Rohmer comenzaron a escribir sobre las películas de Hitcoch o Welles (Noguera 2012: 6). Los textos críticos comenzaron a considerarse como textos autónomos, resultado de una actividad creativa, es decir, como interpretaciones o lecturas que no se limitaban a informar o traducir la película desde el lenguaje audiovisual al escrito, sino a comentarla para situarse en el lugar de mediador entre el público y la obra. La crítica, en su sentido tradicional, no juzga, sino que reflexiona sobre la representación y la comunicación de los elementos que conforman las obras (López Anaya 2007: 64).

En tanto nuestro objeto es la crítica de cine debemos señalar que esta noción engloba producciones de autores provenientes de formaciones muy diversas (periodistas especializados, directores, productores, actores) tanto si consideramos su objeto, su método como al público al que se dirige. Habitualmente se distingue entre la crítica de prensa, polémica o informativa, que reacciona ante un hecho puntual de su presente, y el trabajo histórico o teórico que refiere al largo plazo. La evaluación crítica de una obra cinematográfica supone al menos un doble vínculo, por un lado, con la historia de su tiempo y, por el otro, con problemáticas existentes en la contemporaneidad. Posee una dimensión pedagógica y de iniciación al gran público y promueve la circulación de las ideas en el mundo del cine. La figura del crítico fue adquiriendo peso en numerosos medios de comunicación al facilitar el acceso del público a las obras cinematográficas. En un trabajo sobre la crítica como metacrítica, Oscar Steimberg y Oscar Traversa afirman que la crítica: 
(...) está obligada permanentemente a pensar en la ubicuidad de sus objetos y entonces en su propia, permanente, condición metadiscursiva: discursos sobre discursos, para justificar su existencia no puede dejar de autorreferirse y de ofrecerse como eventual motivo de rechazo o legitimación (2010).

Frente a las mutaciones de sus objetos, Steimberg (2007) identifica como un rasgo de la crítica contemporánea la presencia de una mezcla de roles: por un lado, es cada vez más parte de la obra y, por el otro, debe atender a su propia forma tanto como a su contenido.

Por su parte, Traversa (2007) señala que, en la actualidad, este papel mediador de la crítica clásica habría sido desplazado por una condición poscrítica que se caracteriza por ser una escritura que participa en el movimiento poético del que debería ser su objeto.

La necesidad del discurso crítico en la cinematografía actual viene dada por la existencia de obras que necesitan de una mediación concreta entre el público, más o menos especializado, y sus espectadores. Como todo dispositivo, esta producción de discursos críticos sólo es posible por la disponibilidad, en un momento histórico determinado, de un conjunto de saberes estéticos y técnicos valorados en la sociedad y de medios que posibilitan su difusión y circulación -como el desarrollo de YouTube en nuestro caso.

Al igual que otras prácticas sociales, la crítica cinematográfica ha experimentado cambios en los modos de producción, circulación y consumo a partir del desarrollo de las redes sociales. En general, sabemos que estas redes promueven y acentúan las relaciones de horizontalidad entre usuarios, y generan comunidades on line centradas en intereses comunes. En este trabajo, de carácter exploratorio, nos ocuparemos de analizar las producciones que circulan en YouTube que podrían incluirse en la categoría de textos, audiovisuales, de crítica cinematográfica. En una segunda etapa de nuestra investigación, que aún no hemos desarrollado, nos proponemos efectuar un análisis en reconocimiento del discurso de los usuarios para observar las trayectorias que activan los textos críticos en YouTube.

YouTube -creada en 2005- funciona como una plataforma en la que se pueden consumir, crear, compartir, comentar videos sobre diferentes temáticas. Los tutoriales de YouTube, por citar un ejemplo, juegan un papel fundamental en la educación informal, como también los fenómenos ligados al entretenimiento. Información, entretenimiento, fuente de conocimiento, son componentes que desarrollan en el marco de una cultura participativa como característica de los fenómenos pertenecientes a Internet. Para H. Jenkis (2006) la convergencia mediática, -el flujo de contenidos que circulan a través de múltiples plataformas-, y la inteligencia colectiva -que se genera a partir del intercambio entre usuarios activos que producen, comentan y se organizan 
en función de intereses-, crean comunidades de conocimiento en las que las prácticas interpretativas se constituyen en un discurso compartido que revitaliza lazos sociales.

Diversos son los posicionamientos enunciativos, que en el caso de Youtube, llevan la construcción de la figura el youtuber como influencer, figuras de referencia sobre la que los usuarios depositan su confianza. Una de las preguntas que nos hacemos es hasta qué punto un influencer puede modificar comportamientos de consumo en sus seguidores. Dado que estos funcionamientos no se producen de manera lineal, es importante comprender la dinámica reticular que los constituye.

En la actualidad, los discursos críticos sobre las obras cinematográficas actúan en este escenario de convergencia mediática (Scolari 2008) en el que los cambios en los modos de mirar las películas también conllevan cambios en los modos de hacer crítica. Los fenómenos de mediatización contemporáneos posibilitan que los espectadores tengan a su alcance múltiples discursos que orientan o guíen sus consumos. Al mismo tiempo, el espectador se convierte en crítico ya que a través de sus comentarios realiza una valoración de la obra cinematográfica. El youtuber es un actor social, producto de esta red, que surge como un usuario que adquiere notoriedad por subir videos vinculados a un tema de su interés y que son compartidos con miles de usuarios que "lo siguen". Tal vez, el hecho de que exista la posibilidad de que cualquier usuario cree su propio canal y suba sus propios videos, ha producido en el campo de la crítica especializada, una valoración negativa del youtuber: lo que hace el youtuber no es "verdadera crítica" sino que simplemente son usuarios que comentan sus películas favoritas. Así oponen el saber al entretenimiento. En este sentido, los críticos de cine generan un colectivo de identificación basado en el saber especializado, mientras que los youtubers se inclinan hacia un saber amateur.

Youtube es una plataforma privilegiada para el desarrollo del discurso de la crítica cinematográfica: "broadcast yourself". Por sus posibilidades técnicas facilita la realización de videos breves en los que se comenta o analiza un film, la obra de un director, o brinda información sobre el universo cinéfilo. Estos videobloggins o vloggings, en general, como modelo canónico, consisten en la realización de un monólogo durante el cual el youtuber, instalado en un escenario acorde a la temática, detrás de la mesa, mira a cámara, siempre fija, e inserta las imágenes de las obras a comentar. El youtuber genera así una comunidad de fans de objetos de culto, que se convierten en sus seguidores y juntos, productores y consumidores, promueven la participación.

\section{Críticos vs Youtubers}

Nuestro corpus está conformado por los que se consideran a sí mismo "críticos especializados" y por lo que se presentan como "conocedores del 
tema", por tratarse de un tema de su interés. El recorte lo hemos efectuado observando la cantidad de seguidores y tratando de dar cuenta de la diversidad de formatos. En los videos perteneciente a los que se consideran a sí mismos como "verdaderos críticos especializados", encontramos reflexiones sobre lo que "debe ser" un crítico de cine. ¿Debe recomendar la película? ¿Debe limitarse a analizarla? ¿Debe educar o simplemente informar? No es periodismo, no es análisis académico, ¿cuál es entonces su especificidad?

Dentro de este primer recorte discursivo, el de los críticos especializados, hemos seleccionado los videos de:

- Nicolás Amelio Ortiz / ZEPfilms: es guionista y director de cine. Tiene dos canales, uno sobre su vida cotidiana que según el mismo afirma, le sirve para mantener el contacto con los seguidores, y ZEPfilms que es un canal donde sube videos de películas de acuerdo con diversas temáticas o secciones: historia del cine, Hollywood al desnudo, Cacería de festivales, La historia secreta detrás, Reseñas y opinión, listas y tops de películas y series.

- ZOOM F7: canal integrado por críticos especializados que además publican en otros medios como Rodrigo Garay, Julio Durán, Alonso Díaz de la Vega, Sergio Huidobro. La puesta en escena se centra en el conductor, Gerardo Herrera, que entrevista a los críticos especializados quienes hacen sus recomendaciones e invitan a ver tal o cual film.

- Fernanda Solórzano en Cine Aparte: ensayista, editora y crítica mexicana. Se especializa en crítica cinematográfica. Es Lic. en Literatura. El videoblog se llama Cine Aparte y pertenece a la revista Letras Libres.

- Mundo cinéfilo de Manuel Díaz Mateo: realiza videos breves en el formato más tradicional en los que comenta sus películas favoritas.

En un segundo grupo de discursos ubicamos a los que no se definen a sí mismo como críticos serios y le imprimen humor, con un lenguaje distendido y un tono más descontracturado, a las recomendaciones que efectúan:

- La botella de Kandor de Javier Olivares: se inscribe en el fandom de los comics, cine y series de Marvel. Es de Valencia, tiene 38 años, fan de Superman. Se define como lector, coleccionista, redactor, traductor. Informa sobre la actualidad del Universo Marvel y "temas friks" varios.

- Kristoff Raczynski de La Lata: conductor de TV, director, actor y crítico de cine mexicano. Despliega su histrionismo a partir de sus tonos de voz, gestos y miradas. A la vez que comenta las películas, las califica y utiliza un personaje over, la rata, que hace comentarios más duros.

- Vamos a echarle huevos al cine de Rodolfo Ruiz Palacio: es un director de cine mexicano de 49 años, creador de HuevoCartoom -un estudio de animación-, es licenciado en Ciencias de la Comunicación, Mg. en 
Dirección y Guionismo. La dinámica se basa en ver juntos el trailer de una película - pantalla en pantalla-, e ir comentando al mismo tiempo. Recrea la experiencia de lo que hacemos "antes de ir al cine". Otros videos dan noticias del mundo del cine. $O$ incluso a veces transmite desde su auto, acompañado por su hermano mientras van al cine.

- Te lo resumo Así nomás de Jorge Pinarello: sintetiza películas y series, en videos de no más de 10 minutos y las comenta a través de inserts y de su voz over. El tono de voz y los comentarios, el tipo de lenguaje que utiliza, le imprimen humor.

- Bower to the futur de Bower: no sólo analiza, sino que ofrece una explicación sobre la película que comenta. Brinda datos curiosos y recomendaciones.

Existen prejuicios o preconceptos por parte de quienes son críticos especializados (que en general provienen de las letras y publican en libros y revistas sobre cine) en torno a los youtubers que sólo, según ellos, hacen entretenimiento. Sin embargo, en todos los casos analizados, los youtubers poseen una formación o una actividad laboral vinculada al cine: son directores, guionistas, actores o productores. Estos últimos no se cuestionan ni reflexionan sobre lo que hacen sino que elaboran su videos abordando diversos aspectos de una obra cinematográfica, sin rotular sus producciones como crítica especializada. Las temáticas son variadas: pueden girar en torno a los films de culto, a las películas de cartelera, a la obra de un director, a un género específico, a noticias o informaciones del mundo del cine en general, curiosidades, etc.

\section{Dispositivo enunciativo}

En el corpus que hemos abordado se despliegan diversas estrategias enunciativas. Evidentemente el dispositivo enunciativo de YouTube favorece el hecho de que el espectador siga o se suscriba al canal de su youtuber favorito y que, además, debido a los algoritmos de búsqueda, acceda a contenidos similares a los de sus búsquedas recientes. Como en toda red social, el usuario puede compartir dar likes o comentar los videos. Es fundamental para el crecimiento de la figura del youtuber que este tenga numerosos likes y seguidores. La lógica de marketing que atraviesa el fenómeno de los influencers, requiere de la presencia de anunciantes. Por otro lado, estos actores participan de otras redes sociales y muchas veces son figuras reconocidas por los medios tradicionales a partir de apariciones públicas, publicaciones de libros o de artículos en revistas. La inmediatez y la accesibilidad que caracterizan a estos discursos, sumado a cierta regularidad en la frecuencia en la que se suben los videos, fideliza a los seguidores. Los comentarios validan los videos y se construye un lazo de confianza con el youtuber. En un futuro estudio en recepción, indagaremos hasta qué punto los usuarios se dejan guiar por sus recomendaciones. 
Desde producción, hay dos grandes modalidades enunciativas sobre las que se construye la confianza. Una consiste en posicionarse desde el lugar del saber especializado: el crítico especializado hace aquí un despliegue de conocimientos del mundo del cine que le permite articular un discurso complejo y rico en citas. Se dirige a otro ávido de conocimientos y con el que comparte ciertos conceptos específicos (se dirige al estudioso del tema).

La otra modalidad consiste en situarse desde una posición enunciativa cómplice. Aquí el enunciador comenta desde la simpatía y el humor, brinda una mirada propia, subjetiva, accesible a un otro que no necesariamente sabe de cine, pero que sí sabe del universo sobre el que está hablando por ser consumidor de él. Genera una experiencia compartida de igual a igual basada en un lenguaje común.

Estas dos distinciones son meramente ordenadoras ya que en realidad existen diferentes matices que se despliegan con relación al modo en que cada youtuber se relaciona con lo que dice, es decir, con el enunciado. La creatividad aquí juega un papel importante ya que de ello depende el crecimiento numérico de los seguidores.

La legitimidad del crítico/youtuber para ejercer su opinión se funda así en el modo en que se relaciona con aquello que nos muestra. En cada caso esa autoridad se basa en aspectos diferentes, se funda en el saber, en el humor, en el uso de un lenguaje común, de referencias compartidas, en los modos de generar un proceso de identificación. La figura del "crítico en un pedestal" que dice qué es bueno y qué es malo se vuelve obsoleta. Lo que hallamos son estrategias que minimizan esas distancias asimétricas entre enunciadores y destinatarios. Si bien el youtuber habla desde algún campo del conocimiento, también lo hace desde el desconocimiento, desde el asombro, la sorpresa, o el desencanto. El sólo hecho de presentar su opinión como tal, exhibir que se trata de material opinable, lo hace más creíble. Mostrarse como un discurso relativo, atravesado por apreciaciones personales, lo acerca más al destinatario.

El lenguaje audiovisual de Youtube permite que entren en juego otros aspectos que modelan la relación con los destinatarios: por un lado, lo que la cámara muestra en relación con el escenario elegido para realizar la transmisión, ese escenario enmarca los sentidos que genera, frente a la cámara siempre fija, el histrionismo del youtuber, su tono de voz, la velocidad con la que habla, vestimenta, los gestos, la mirada, el orden de lo corporal. Pero también los insertos, las imágenes de archivo utilizadas para comentar, el registro verbal (coloquial/serio). Se abre un vasto campo de configuraciones del sentido en lo que corresponderían a los órdenes de lo icónico, indicial y simbólico, en términos de Peirce. Fundamentalmente, el registro de lo indicial, es decir, lo que corresponde al cuerpo y a la mirada, cobra aquí singular importancia en el modo en que se construye la relación con la "comunidad". El eje de la confianza, como decíamos más arriba, se basa en la figura del youtuber. El nexo que se 
construye entre el youtuber y su comunidad a partir del funcionamiento indicial es fundamental (Verón 1983). Aún en los casos en que sólo se escucha la voz del youtuber, el funcionamiento indicial es el hilo conductor que ayuda a enseñar, orientar, explicar o guiar la mirada del espectador.

Esta acción orientativa, tiene como finalidad hacer que los seguidores vayan al cine o vean tal o cual película. Lo que las estrategias estudiadas ponen de manifiesto son variaciones en los argumentos elegidos para la persuasión. La crítica especializada, construye argumentos en torno a un campo de saber complejo, ciertos valores e intereses propios de un grupo conocedor del film. Otra estrategia es la que adoptan algunos youtubers, que no se llaman a sí mismos críticos, y consiste en poner el acento en su creatividad para hacer más fácil la comprensión y visualización de ciertos films. En ambos casos, los destinatarios darán sus opiniones a través de los likes, compartidos y comentarios. Este intercambio de opiniones es fundamental para construir la comunidad seguidora de tal o cual youtuber y demuestra la capacidad de estas prácticas discursivas para generar un encuentro de subjetividades.

Otro aspecto fundamental, característico de las redes sociales, es la ampliación del alcance, el acceso (Verón 2013), del público a películas que de otro modo no conocería o no podría ver, el acceso del público al film es un proceso cada vez más veloz. De hecho, esto surge en concomitancia con el spoiler, esto es, la revelación de datos importantes que puedan malograr el visionado de una película. Muchas críticas de cine revelan detalles importantes de la trama que restan posibilidad de disfrute al espectador. De todas maneras, existe un acuerdo tácito de avisar si ese artículo contiene spoiler.

Las críticas se centran en la estética, en el argumento, en las vinculaciones con otras obras del mismo director o en los valores que la obra promueve. Existe un cruce discursivo entre los que refieren a la dimensión estética del film, los que toman al cine como un fenómeno social a analizar o los que lo abordan desde el punto de vista del entretenimiento cotidiano. Todos discursos a su vez determinados por la lógica de marketing que posibilita el crecimiento de los canales.

La puesta en escena y las modalidades discursivas adoptadas varían. Aparece la entrevista, el análisis, la opinión o comentario (que valora la película), la explicación (en general con una voz over).

Con respecto a estas diferencias no parece haber una relación directa con la distinción crítico especializado/youtuber. No obstante, constatamos la existencia de estos dos grandes posicionamientos enunciativos, uno centrado en la terceridad en tanto es un discurso que se rige por reglas y hábitos interpretativos de una comunidad de estudiosos, y el otro centrado en la primeridad en tanto el enunciador manifiesta emociones, percepciones y afectos a través de su corporalidad. 


\section{Algunas hipótesis para el análisis en reconocimiento}

A partir de este análisis exploratorio, nos planteamos algunas preguntas que guiarán el futuro análisis en reconocimiento. Por ejemplo, los usuarios ¿reconocen estas tensiones entre críticos especializados y youtubers? Y, si así fuera, ¿de qué modo influiría eso en el consumo de los videos? ¿Qué aspectos se privilegian para la elección de tal o cual canal? O vinculado a esto, ¿cuáles son las trayectorias o recorridos que se activan en la mente de los consumidores en relación a la crítica en YouTube?

También sería interesante preguntarnos por las trayectorias en los visionados: ¿sigue el recorrido propuesto o procede de a saltos? ¿El receptor es un sujeto pasivo que contempla y se coloca en el lugar de la expectación? ¿O activa trayectos, entendidos como funciones cognitivas, de acuerdo a sus motivaciones, mantiene una distancia y hace una lectura personal?

A fin de caracterizar ese consumo, los usuarios, ¿mantienen una lealtad hacia el crítico?, ¿traduce sus gustos en demandas? ¿Qué colectivo de identificación, si es que hay alguno, se genera en los receptores?

\section{Conclusiones}

Cada video analizado que vehiculiza una crítica a la obra cinematográfica construye en su interior representaciones en torno al mundo del cine, del papel del crítico y del lugar que se le asigna al público. Las diversas configuraciones discursivas responden a los modos en que se construyen estas representaciones en YouTube.

En los que se consideran a sí mismos como críticos especializados, el youtuber hace valer su saber para seleccionar los datos que va a poner en relación. Al mismo tiempo convoca a la racionalidad del público que deberá entender la relación entre el film y la sociedad que lo produce, mientras que el crítico cumple un papel de mediador entre el film y los usuarios. Denominaremos a esta posición enunciativa como la del crítico teórico: hace una historia del cine o se centra en la obra de un director.

El otro conjunto de discursos críticos elige un posicionamiento enunciativo más subjetivo, aunque se presenta como conociendo las obras de las que habla, el crítico es un espectador más, da su opinión, exhibe sus gustos. Convoca a los afectos y las emociones en sus seguidores a través del humor y la creatividad de la puesta en escena. El mundo del cine es un mundo para ser disfrutado. Lo denominaremos el crítico sensible: domina lo subjetivo, las propias impresiones.

Los discursos críticos cumplen la función de articular producción y reconocimiento, y las transformaciones en los procesos de circulación transforman los estilos en producción. El entretenimiento, la información y el conocimiento son tres componentes de Youtube que se combinan de manera diferente en cada discurso analizado lo que le da una particularidad al dispositivo 
enunciativo del youtuber quien se asentará en los componentes evaluativos, que responden a las leyes del saber cinematográfico (terceridad) o en componentes evaluativos conectados con las propias emociones del enunciador (primeridad).

Dado que YouTube es una plataforma mediática atravesada por la lógica del marketing, los youtubers compiten entre sí por captar seguidores y al mismo tiempo se reenvían unos a otros. El componente creativo en sus discursos es un diferencial para captar mayor número de seguidores. En todos los casos, los discursos críticos se centran en los aspectos estéticos de la obra cinematográfica, en el cine como fenómeno social o en el cine como entretenimiento. Cada una de estas elecciones define la relación entre el crítico/youtuber y su comunidad de seguidores. Por otra parte, hemos visto que esta relación entre el crítico/ youtuber y su comunidad se asienta en lazos indiciales que descansan en el cuerpo como operador de sentido. Ese lazo contribuye a generar la confianza en el marco de procesos de identificación entre los usuarios consumidores.

Si observamos los cruces y transposiciones con otros medios, diríamos que, con el desarrollo de la crítica de cine en YouTube, el fenómeno que se amplifica se vincula con su capacidad de promover la ampliación del acceso a los espectadores a películas y series (un objeto cultural de la crítica paralelo al de la cinematografía).

\section{Bibliografía}

JENKIS, Henry. 2008 [2006]. Convergence Culture. La cultura de la convergencia de los medios de comunicación. 1ra ed. en castellano. Barcelona: Paidós.

LÓPEZ ANAYA, Jorge. 2007. Historia del Discurso Crítico. Temas de la Academia: discursos de la crítica (5), 61-68. Buenos Aires: Academia Nacional de Bellas Artes.

NOGUERA, María. 2012. El arte de la buena crítica de cine. Perspectivas del Mundo de la comunicación (72). Universidad de Navarra, España.

SCOLARI, Carlos. 2008. Hipermediaciones. Elementos para una Teoría de la Comunicación Digital Interactiva. Barcelona: Gedisa.

STEIMBERG, Oscar. 2007. Cuando toda crítica es metacrítica. Temas de la Academia: discursos de la crítica (5), 105-108. Buenos Aires: Academia Nacional de Bellas Artes.

STEIMBERG, Oscar y TRAVERSA, Oscar. 2010. Objetos de la Crítica. Revista Figuraciones (7) IUNA, Crítica de Artes. http://www.revistafiguraciones.com.ar (última visita 22 de Julio de 2011). 
TRAVERSA, Oscar. 2007. Dos relatos de Buzzati situados en la Bienal de Venecia. Temas de la Academia: discursos de la crítica (5), 125-130. Buenos Aires: Academia Nacional de Bellas Artes.

VERÓN, Eliseo. 2003 [1983]. Il est là, je le vois, il me parle [Está ahí, lo veo, me habla] Paris, Communications: Enonciation et cinéma (38), trad. castellana, María Rosa del Coto, Secretaría de publicaciones de la Carrera de Ciencias de la Comunicación, Facultad de Ciencias Sociales, Universidad de Buenos Aires.

VERÓN, Eliseo. 2013. La semiosis social,2: ideas, momentos, interpretantes, Buenos Aires: Paidós. 


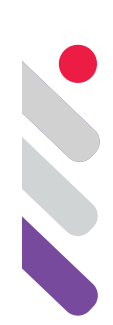

\section{Folklore digital, prosumidores y creepypasta}

DOI: 10.24308/IASS-2019-5-011

Sandra Sánchez

Universidad Nacional de las Artes - Universidad de Buenos Aires.

sandravsanchez@fibertel.com.ar

\section{Resumen}

Diversos y valiosos estudios describen el fenómeno del folklore digital desde la antropología (Cañas Murillo et al. 2010; Díaz GonzálezViana 2003; 2017; Brunvand 1998); no obstante, considero que un abordaje desde la Sociosemiótica puede hacer aportes enriquecedores para entender, por ejemplo, las características de los modos de producción y circulación de los géneros narrativos etnopoéticos en la esfera digital. De hecho, ya en 1999, Martha Blache, afirmaba que, para abordar la significación, los folkloristas deben recurrir a enfoques interdisciplinarios, ya que el campo de comprensión del significado abarca tanto la lingüística, como la semántica o la semiótica. Ahora bien, las plataformas actuales (Fernández 2016) y sus posibilidades de producción e interacción incluyen elementos heredados de las prácticas y formas de producción e interacción desarrolladas por las plataformas predecesoras en relación con las formas de narrar y de poner en circulación mitos, leyendas, cuentos populares, leyendas urbanas en la esfera digital (Netlore). El corpus está constituido por textos que se mediatizan vía algún tipo de plataforma de escritura colaborativa (plataformas de contenidos generados por los usuarios; van Dijck 2016). Aquellos que conforman un espacio virtual de trabajo destinado a la construcción de un proyecto, al intercambio de información o de conocimientos y que ponen todas estas herramientas a disposición de los diferentes actores involucrados: los prosumidores (Bruns 2008). Es uno de mis objetivos abordar el caso de los relatos etnopoéticos denominados creepypastas. Los creepypastas presentan una enorme variación de motivos que pueden nacer de mitos, leyendas, leyendas urbanas, rumores, cadenas, cuentos tradicionales y que son sometidos a una constante reelaboración por parte de los prosumidores. Se trata de relatos de terror escritos o narrados de forma oral que advierten sobre peligros ancestrales, atávicos, o actuales 
(Cortazar Rodríguez 2014). Los lectores se apropian de un tema o de un motivo del que ofrecerán luego, en y para su comunidad, diversas variantes estilísticas de una misma historia. Este tipo de literatura digital (ciberliteratura) es un fenómeno popular de alcance relativamente masivo (Fernández 2016); a causa de su carácter de escritura comunitaria y colaborativa presenta muchas y variadas restricciones genéricas (co-gestionadas por los participantes), que son controladas por un monitoreo constante propio del intercambio discursivo lo que genera una constante tensión entre espectadores y productores.

\section{Netlore}

Las leyendas, rumores y cadenas han circulado oralmente o por escrito, en diversos soportes, desde hace siglos. En el siglo XX, reaparecen en forma oral, por ejemplo, las leyendas urbanas; pero diversos géneros se difunden por medio de fotocopias (el llamado Copylore o Xeroxlore) y a través del fax (Faxlore), también por mail y posteriormente en toda la Web (Netlore). El primero en utilizar el término Netlore fue el folklorista Jan Harold Brunvand (1998). Hoy en día se reserva el concepto para las producciones escritas; en pocas ocasiones, se observa el uso de $E$-folklore para los textos de transmisión oral.

Francisco Javier Cortazar Rodríguez retoma una idea de los '70 y denomina Screenlore al "moderno folclore popular mediado por las industrias culturales a través de las pantallas de las tecnologías de la comunicación e información" (Cortazar Rodríguez 2014: 193). Se trata de todo tipo de relatos nacidos a partir de películas, programas o series de televisión, publicidades, video juegos, cortos. Este proceso de producción también se observa de modo inverso; esto es, relatos nacidos del folklore urbano que son tomados como tópico por películas, series, cortos, etc. (rasgo característico de los relatos creepypasta).

El Netlore comprende diversas manifestaciones como el Fakelore o el Coke-lore. Se lo denomina también Folklore moderno o Folklore digital; puede formar parte de la Literatura de los márgenes, de la Literatura Popular, de la Literatura de la esfera digital. Por ejemplo, la Wiki Creepypasta se define como "una wiki dedicada a recopilar y mostrar la mayor cantidad de información posible sobre literatura de terror".

Forman parte del Netlore, además, los textos pertenecientes a los géneros narrativos etnopoéticos que circulan en la esfera digital, que son los que ocupan a esta investigación. Se denomina géneros narrativos etnopoéticos a los textos escritos $u$ orales de base narrativa que alertan sobre peligros ancestrales o de reciente aparición. Entre los géneros narrativos etnopoéticos que circulan en la esfera digital encontramos: los rumores y las noticias falsas, las leyendas urbanas, las cadenas que narran algún suceso, los engaños (hoax) que se basan en alguna historia, los textos conspirativos de base narrativa, los creepypastas. Algunos de los tópicos de los géneros narrativos etnopoéticos 
son lo sobrenatural, los miedos ancestrales atávicos, pero también los peligros y consecuencias del desarrollo científico y tecnológico, entre muchos otros; tópicos que conviven, no se reemplazan mutuamente (Sánchez 2019).

En ellos el horizonte de expectativa del lector se constituye a partir de una característica y función de los géneros narrativos etnopoéticos: alertar, prever, mostrar, difundir y develar intrigas y misterios que en otros géneros son ninguneados o bastardeados. Estos textos narrativos estabilizan para su sociedad la concepción de un peligro de cualquier clase, por lo que entendemos cumplen una función moralizante, razón por la que podemos caracterizarlos como didáctico-moralizantes (Sánchez 2019).

\section{Los creepypasta como género narrativo etnopoético}

Ahora bien, los tipos de escritura que interesan, especialmente, a nuestra investigación son los que se mediatizan vía algún tipo de plataforma de escritura colectiva colaborativa; en otras palabras, aquellos que conforman un espacio virtual de trabajo destinado a la construcción de un proyecto, al intercambio de información o de conocimientos y que ponen todas estas herramientas a disposición de los diferentes actores involucrados, como es el caso de los relatos denominados creepypastas. En "Folklore digital: la vigencia de las leyendas urbanas en los creepypasta" (Sánchez 2018), estudiamos con profundidad el fenómeno, por lo que aquí sólo sintetizaremos algunos rasgos.

Los creepypasta son relatos, en general breves, a menudo autorreferenciales, que se centran en experiencias personales de un motivo que se repite. Son similares a las leyendas urbanas (muchas son leyendas urbanas adaptadas a la esfera digital, como la rata del Ganges); se los puede asociar también con las historias de terror que se narran en los campamentos o en reuniones de adolescentes. Se mediatizan en wikis también vía audio o texto de WhatsApp, como cortos audiovisuales en YouTube, en blogs, etc. La edad de los usuarios oscila entre la pubertad y la adolescencia.

Las narraciones creepy presentan características similares a las de los cuentos de tradición oral, pero son los usuarios pueden, a partir de cada relato, apropiarse de un tema o de un motivo del que ofrecerán luego, en y para su comunidad, diversas variantes estilísticas de la misma historia. Algunas historias son copiadas / pegadas una y otra vez, como en el siguiente ejemplo que, como todos los que incluiremos, será copiado textualmente, incluyendo sus errores de ortografía:"Las historias no son relatadas por mi, sino sacadas de distintas paginas para compartirlas todas aquí. Asi que, gracias al autor y espero no le moleste"(https://www.wattpad.com/story/16186856-leyendas-urbanas-deargentina).

Pero muchas son alteradas, vueltas a narrar de nuevas y diversas maneras. Presentan una enorme variación de temas y motivos tomados de 
mitos, leyendas, leyendas urbanas, cuentos tradicionales, rumores, noticias falsas y cadenas, films, series, videojuegos, comics y que son sometidos a una continua transformación y reelaboración por parte de los usuarios.

Estas plataformas permiten construir las historias en una territorialidad expandida lo que es propio de los géneros narrativos etnopoéticos. Es factible rastrear una historia a través de una región y observar sus diversas variantes, los relatos creepy evidencian este rasgo (volver a narrar lo narrado) que se enuncia comúnmente al inicio: "A mi me contaron una parecida (ya no me acuerdo ni quien), pero la historia era la misma, y había pasado acá, en Corrientes" (https://www.reddit.com/r/argentina/comments/y0ryg/historias_relatos_ mitos_leyendas_creepypastas/).

Los creepypasta son adaptaciones. Para ser más exactos, hay versiones y transposiciones. La versión implica las diversas concreciones de una misma historia o motivo en un soporte homogéneo. En el caso de los creepypastas, hay transposición cuando un texto se difunde en audio, cuando al audio se le agregan imágenes o cuando el texto se utiliza para grabar un video. Los usuarios suelen ser muy críticos respecto de estas características, por ejemplo:"La verdad que no merece estar aquí, fue un experimeto real al que se le aportó una película. La historia de quien es???? No es una pasta".

En general, poseen el rasgo inquietante del puede ser. Un creepypasta auténtico se caracteriza por sembrar la duda en el lector respecto de los límites entre realidad y ficción, por ejemplo:"Siempre me ha parecido muy buena la historia de los Holders, espero que sea verdad" (https://www.dragonmecanico. com/2016/10/the-holders.html).

El verdadero espíritu creepypastero pretende despertar en el lector un temor ancestral al presentar un relato misterioso en el que el narrador se incluye como protagonista o testigo pero también sus amigos, parientes, vecinos. En todos ellos se entremezclan realidad y ficción; predomina el hacer-saber la verdad, lo que genera duda de si lo narrado tiene alguna explicación lógica o no. Los comentarios refuerzan esa idea.

\section{Lectores, críticos, jueces, correctores, escritores, reescritores, editores divulgadores: ¿prosumidores?}

¿Qué cambio produce la emergencia de un prosumidor capaz de desempeñarse como lector, crítico, creador, versionista y distribuidor? Al igual que la literatura popular oral, los creepypastas se pueden recrear, por lo que cada usuario puede intervenirlos realizando las modificaciones que crea pertinentes; esto los transforma en creaciones colectivas y colaborativas, en algunos casos anónimas, a saber: "TheHolders es una serie extensa de creepypastas basadas en un esquema de construcción claramente delimitado. Se trata de una colección colaborativa, con los aportes de muchos autores, 
que se halla reunida en la página http://theholders.org/ (en inglés). Les dejo la introducción a esta serie, para comenzar seguidamente a publicar las historias. Espero que las disfruten" (http://veamosunademiedo.blogspot.com/2013/05/ the-holders-ntroduccion.html).

El usuario opera como produsuarioo prosumidor (Bruns 2006) ya que, además de leer, critica, reescribe, edita, juzga, publica, difunde; es decir, interviene activamente en el consumo, en la producción y en la puesta en circulación. Se convierte él mismo en parte de la historia y controla parcialmente la dirección de la experiencia estética que resulta, a menudo, de apariencia híbrida.

Debemos destacar que como produsuario cumple una función fundamental al poner en circulación los relatos y compartirlos en la esfera digital o darlos de baja. Es decir, estos géneros forman parte de la cultura participativa, "dependen de la participación activa de los consumidores que son los que buscan nuevas historias y establecen conexiones entre contenidos mediáticos dispersos" (Jenkins 2008: 15).

Esta constante interacción discursiva afecta la producción, ya que las narraciones están siempre en construcción y cambiando; en algunos casos, merced a los comentarios que recibe cada versión de la historia en términos de "me dio miedo", "no me asustó", "eso es mentira", o desmitificando el relato "yo vivo en esa ciudad y eso no es cierto", "la empresa sacó un comunicado y no es verdad"; o corrigiendo la veracidad de la historia: "vivo en tierra del fuego y se cuanta acá que nunca fue una excursión demaestros, eran familias acampando, encontraron cuerpos de 3 mayores y el de todos los nenes menos el cuerpo de una nena que es lo que según dicen los que acamparon la ven y pide ayuda, espero que te sirva la información"(https://www.wattpad.com/49566255leyendas-urbanas-de-argentina-leyendas-de-terror).

Estos comentarios evidencian las gramáticas de reconocimiento, correspondientes a las lecturas o interpretaciones que a la vez originarán nuevas correcciones y reescrituras que producirán otras versiones. En palabras de Linda Dégh: "la leyenda es un proceso que difunde y discute ideas fundamentales concernientes a la existencia humana, y no un producto" (Dégh 1999: 34).

El produsuario, que versiona, media para que el motivo llegue reformulado y adaptado. De hecho, se narra una historia o motivo y al versionarla se la adapta al auditorio y a la plataforma en la que circula. Se versiona la historia, se escribe, se reescribe, se corrige: es necesario indagar, entonces, respecto de cuáles son las modalidades de este intercambio discursivo social (Fernández 2016: 75).

Los comentarios establecen una suerte de diálogo entre usuarios que se cuentan diversas o la misma historia una y otra vez. En ciertos casos, el intercambio se vuelve desmitificador hasta llegar al insulto. Se trata de lectores que no pactan con el género y tratan de locos, estúpidos o mentirosos a los otros escritores. 
Lo mas impresionante aqui, es que hay gente que cree que esto es verdad jaja, señores, sean realistas, este en un mundo aburrido, donde lo mas peligroso somos nosotros y nuestras ansias de eliminar todo a nuestro alrededor, sepan pues que probablemente este es el inifierno y todos fuimos condenados XD, me saliopoetico, ahora saldra gente a decir que esto es verdad (https://creepypasta. fandom.com/es/wiki/Los_Holders).

Quizás esta sea una razón extra para que creepypastas, Tweetcuentos o ChatStories circulen de forma anónima o firmadas con un nickname.

\section{Las plataformas de escritura colectiva, colaborativa y el control}

En las wikis se especifica que el objetivo de este tipo de trabajo colaborativo es conformar un proyecto específico: facilitar y optimizar la comunicación entre los usuarios, hacer circular información, valorar la creatividad, distribuir y evaluar los relatos producidos, calificarlos, optimizar las narraciones y jerarquizar la plataforma al corregir y reescribir colectivamente los textos. Es por esta razón que las características genéricas de los relatos creepy, las restricciones genéricas (que configuran estrictas normas de publicación) son co-gestionadas por los participantes en un constante intercambio discursivo. Por ejemplo:

A favor. Su comienzo es aceptable, la ortografía esta bien, pero cuando inicia lo "terrorífico" deja mucho que desear, es la creepy clásica cliché con lo de Satan, el 666 y el gore (ademas de que escribió mal "Satan") ademas tiene algunos errores de redacción. Lo que trato de decir es que la historia es un poco aceptable pero lo arruina todo con el cliché de los episodios perdidos, tengo lastima por el creepy, creo que se podía haber hecho una buenas historia con el comienzo, es salvable pero se los dejo a ustedes (https://creepypasta.fandom.com/es/wiki/ Wiki_Creepypasta:Proyecto_Guillotina).

Esta escritura colectiva y colaborativa está monitoreada con un rigor similar al de las instituciones educativas; Fraticelli (2019) se refiere a las jerarquizaciones del colectivo internas al medio, en nuestro corpus se evidencia que los participantes parecen imitar un tipo de jerarquización propio de la institución escuela, a partir de la conformación de dispositivos de control como "la administración" y "la moderación", que incluyen sanciones ("El filo de la muerte", "La guillotina") y oportunidades ("El centro de adopciones").

Además de escribir las reglas y el Reglamento (detallado y riguroso), son los administradores quienes establecen una relación claramente asimétrica con los usuarios, a quienes ofrecen variada ayuda estableciéndose entre sí un contrato pedagógico (Verón2005), a la vez que exhiben un saber hacer propio del ethosdocente, lo que se pone de manifiesto en la forma del intercambio 
espectatorial inserto en estas plataformas interaccionales, generando una constante tensión entre enunciadoresadministradores, moderadores, productores, correctores, críticos, editores y lectores. Por ejemplo:"Es mi nuevo creepy siento que me quedo bien, me gustaria pedirles a los administradotes que no borren mi creepy, me tarde mucho en conectar ideas para crearlo xd, me gustaria que siga siendo parte de la wiki" (https://creepypasta.fandom.com/es/ wiki/Usuario_Blog:Mr._creppy/El_angel_del_infierno:El_juicio_final).

Este tipo de literatura digital (ciberliteratura) es un fenómeno popular y masivo; a causa de su carácter de escritura comunitaria y colaborativa presenta muchas y variadas restricciones genéricas, que son controladas por un monitoreo constante propio de este intercambio discursivo, como se puede leer en comentarios como: "creo que faltó un poco más de desenlace pero esta perfecta"; "no me gusto para nada"; "un final bastante profundo y con mucho misterio, sin duda mi voto es positivo y te digo que es uno de los mejores que he leído. por favor no dejes de escribir mascreepys como este. Felicitaciones". Muchos escritores, quizá previniendo comentarios negativos, incluyen una forma de captatiobenevolentiae al inicio, a saber: "Mil disculpas, esto lo escribi/ hice/copie hace mucho, apenas entraba al mundo de la lectura y apenas sabia redactar, ahora mi idea es seguir subiendo leyendas, relatos, historias y así de terror. La verdad esto lo hice por entretenimiento, nunca pensé que alguien llegaría a leerlo, gracias por comentar"(https://www.wattpad.com/49566255leyendas-urbanas-de-argentina-leyendas-de-terror).

Tal vez, ese tipo de exposición a lectores críticos sea la razón por la que abundan más los lectores que los productores. En el siguiente ejemplo tomado dehttp://es.creepypasta.wikia.com/wiki/Wiki_Creepypasta, se puede observar la preocupación de los administradores por conservar la calidad de los relatos:

Si deseas comenzar a escribir, hay algunas cosas que deberías conocer antes de ponerte a ello, como por ejemplo qué es una creepypasta, y qué son las Pseudo-creepypastas. Además deberías leer el Reglamento, así te evitas muchos problemas. Si no sabes cómo publicar tu creepypasta, visita Cómo publicar. Recuerda que esta es una Wiki, y por tanto, una vez que subas tu creepypasta todos podrán leerla y editarla. Los artículos del tipo killer (derivados, relacionados o basados en Jeff theKiller) no son aceptados en esta Wiki, y serán borrados. Ante cualquier duda o comentario contacta a los Administradores de la Wiki.

Esto vuelve lúdica, participativa y comunitaria a la experiencia de escritura, pero controlada. No sólo hay un orden estricto, sino que hay usuarios que actúan con firmeza en el cuidado del orden y seguimiento de las normas(en algunas wikis, a los administradores se les exige una cualidad que los hace únicos: responsabilidad). 
Los usuarios reciben explicaciones detalladas acerca de cómo escribir un creepypasta, se les ofrece guía, ayuda, apoyo para desarrollar su potencial de escritores. De modo que la plataforma le da al usuario un marco institucional de contención; a cambio, se exige seguir la normas, en otras palabras, responsabilidad, de otro modo el infractor recibe sanciones. Sin embargo, los relatos que no cumplen con las reglas son enviados a "La Guillotina":"La leyenda cuenta que aquí, en el Proyecto Guillotina, vienen todos los artículos que deben ser juzgados por diversas razones, iy tú decides su destino! ¡Ayuda a mantener el control de calidad de la Wiki!" (https://creepypasta.fandom.com/ es/wiki/Wiki_Creepypasta:Proyecto_Guillotina).

Si los relatos no merecen La Guillotina, pasan al Centro de Adopciones, donde pueden ser "adoptados" por un "editor adoptante" para "tener un mejor futuro", "una segunda oportunidad". En estos casos, los relatos son sometidos a una reescritura pero con la exigente supervisión de los encargados del proyecto y del editor adoptante. Cito parte de un Reglamento:"En Adopciones se proponen generalmente:

Creepypastas mal traducidas, incluso las muy mal traducidas, sin excepción.

Creepypastas mal redactadas que obedecen con la mínima calidad (no merecen sentencia en la Guillotina, pero tampoco se pueden pasar por alto).

Creepypastas muy extensas con errores de formato (mal uso de códigos)". (https://creepypasta.fandom.com/es/wiki/Wiki_Creepypasta:Proyecto_ Guillotina/Adopciones).

\section{Conclusiones}

Los creepypastas son breves relatos de terror que circulan en diversas plataformas de escritura colectiva colaborativa y que retoman la tradición de los cuentos y leyendas populares orales. Tanto la lectura, como la escritura y la administración de las plataformas en las que se producen los creepy requieren de un dominio de los aspectos genéricos que caracterizan a estos textos, de competencia lingüística y de conocimientos de edición y manipulación de imágenes digitales, entre otros muchos saberes, como se evidencia en los reglamentos de las diversas plataformas que hemos relevado.

A lo largo de esta investigación hemos observado un cambio de mediatización. Por ejemplo, las leyendas circulaban privilegiadamente de forma oral. No se registran cambios notorios en los géneros, pero sí en la economía, facilidad y velocidad de transmisión y en la posibilidad de manipulación de las historias que hacen los prosumidores.

También se destacan las relaciones que entre ellos se generan, dado que pueden participar como actores de la mediatización de un espacio virtual de fácil acceso para compartir, discutir información y para escribir de forma colectiva o individual; los folkloristas llaman a este proceso reinvenciones 
colectivas (Brunvand 1998). Como es sabido, en lo pragmático, esto favorece la creación de comunidades virtuales e incluso de tribus virtuales. El produsuario hace una apropiación individual de un género colectivo, anónimo, participa de él y lo vuelve al anonimato o no.

Ahora bien, la interacción en las plataformas de escritura colectiva y colaborativa favorece la aparición de distintos sujetos discursivos, cuyo desempeño no es posible analizar con la noción de produsuario únicamente. A lo largo de nuestra investigación hemos relevados sujetos discursivos colectivos o individuales como los administradores y los moderadores; pero también lectores, escritores, correctores, reescritores, editores y críticos (despiadados y compasivos). Esto evidencia la conformación de una subjetividad lectora colectiva que determina una nueva concepción de autoría y una nueva forma de leer con niveles, en algunos casos, semejante a la lectura evaluativa del docente.

Hemos observado, también, que se genera una lectura y escrituras colectivas, con la típica estrategia de la "corrección o evaluación entre pares", disciplinadas a partir de la evaluación y la sanción propias de la escuela. En este sentido, emergen (y se requieren) saberes escriturarios ligados al discurso literario y al género discursivo en cuestión: se diferencian los relatos orales de los escritos, se busca la coherencia y la cohesión, se exige el conocimiento de la norma, etc.

Si bien la lectura aparece unida al placer, en primera instancia, luego se observa un tipo de lectura evaluativa, crítica: el que juzga la veracidad de la historia, el que juzga los rasgos genéricos, la calidad literaria, el que imita al maestro de niños pequeños "me encantó tu pasta, sigue así", "muy buen intento, pronto vas a mejorar,prestá más atención a..."

Esta investigación se continuará indagando las características que presentan los produsuarios, como comunidad discursiva mediática, pero poniendo en evidencia que se debe prestar atención a la variedad de sujetos discursivos, en tanto enunciadores, que se evidencian en esta primera aproximación.

\section{Bibliografía citada}

BRUNS, Axel. 2006. Towards Produsage: Futures for User-Led Content

Production, in Fay SUDWEEKS, Herbert HRACHOVEC \& Charles

ESS (eds.),Cultural Attitudes towards Communication and Technology. 275-284.

Tartu, Estonia.

BRUNVAND, Jan Harold. 1998. The Study of American Folklore. New York: W.W. Norton \& Company.

CAÑAS MURILLO, Jesús. 2010.Literatura popular e identidad cultural: estudios 
sobre folklore, literatura y cultura popular en el mundo occidental. Cáceres: Universidad de Extremadura.

CORTAZAR RODRÍGUEZ, Francisco Javier. 2014. Imágenes rumorales, memes y selfies: elementos comunes y significados.Iztapalapa Revista de Ciencias Sociales y Humanidades(35) 77. 191-214.

DÉGH, Linda. 1999. ¿Qué es la leyenda después de todo?EnMartha BLACHE Folklore urbano. Vigencia de la leyenda y los relatos tradicionales. Buenos Aires: Colihue.

DÍAZ G. VIANA, Luis. 2003. La aldea fantasma: problemas en el estudio del folklore y la cultura popular contemporáneos. RDTP LVIII (1). 29-46.

DÍAZ G. VIANA, Luis. 2017. Miedos de hoy: Leyendas urbanas y otras pesadillas de la sobremodernidad. Salamanca: Editorial Amarante.

JENKINS, Henry. 2008. Convergence culture. La cultura de la convergencia de los medios de comunicación. Barcelona: Paidos.

FERNÁNDEZ, José Luis. 2016. Plataformas mediáticas y niveles de análisis. InMediaciones de la comunicación 11(1). 71-96.

FRATICELLI, Damián. 2019. Los colectivos mediáticos de las redes. Algunas observaciones desde el humor ¿y más allá? InMediaciones de la Comunicación 14(1). 47-63.

SÁNCHEZ, Sandra. 2018. Folklore digital: la vigencia de las leyendas urbanas en los creepypasta.Revista Heterotopías 1(1). 168-180.

SÁNCHEZ, Sandra. 2019. Netlore: una aproximación a los textos narrativos etnopoéticos.En María Esther GORLERI (ed.), La literatura argentina en el Bicentenario. Balances del sistema y diálogos con el mundo, 499-508.Formosa: Universidad Nacional de Formosa.

VAN DIJCK, José. 2016. La cultura de la conectividad. Una historia crítica de las redes sociales. Buenos Aires: Siglo XXI.

VERÓN, Eliseo. 2005. Fragmentos de un tejido. Barcelona: Gedisa. 
NUEVAS MEDIATIZACIONES DEL

ESPACIO URBANO 



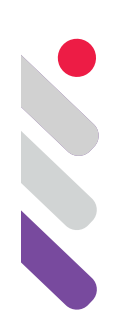

\title{
Semiótica narrativa en el discurso publicitario contemporáneo: análisis de la landing page de "Manantiales" del Grupo Edisur
}

DOI: 10.24308/IASS-2019-5-012

\author{
Angelelli, Belén \\ CIECS-CONICET \\ bel.angelelli@gmail.com \\ Vaccaro, Natalia Desirée \\ CIECS-CONICET \\ natyvaccaro@gmail.com
}

\section{Introducción}

En este trabajo nos proponemos abordar una de las piezas de lo que reconocemos como Dispositivo Publicitario (Boito et al. 2015) de la "Desarrollistas Urbana" (DU) Grupo Edisur S.A de la ciudad de Córdoba, Argentina. Nos concentramos en sus elementos estructurales por lo que, para ello, retomaremos las herramientas de análisis que aporta la propuesta de AlgirdasGreimas en lo que respecta al recorrido generativo de sentido (1980).

Concebir a la publicidad como dispositivo implica entenderla como una red de elementos heterogéneos que generan valor no sólo económico sino también ideológico, como una política "...cuyo fin es gestionar, gobernar, controlar y orientar en un sentido que se pretende útil los comportamientos, los gestos y los pensamientos de los hombres" (Agamben 2015:17). Entonces, nuestra reflexión sobre la publicidad conlleva no sólo analizarla desde una mirada basada en los estudios del marketing, es decir, como una estrategia discursiva de seducción, o como discursos dirigidos a la creación de mercados monopolizados que den ganancias extraordinarias; ni sólo como un género discursivo (Bajtín 1998) aunque presente características genéricas; sino como parte de una política de regulación de la sensibilidad.

Aquí, particularmente, retomaremos algunos elementos de la semiótica greimaciana para realizar una entrada analítica a los discursos publicitarios que nos permita reconocer sus elementos estructurales. Greimas, inscripto en la 
corriente estructuralista de estudios semióticos, postula que la semiótica toma el sentido, anterior a cualquier producción discursiva, para estudiar su lógica y producir un nuevo discurso sobre él; así intenta hacer comprensible, inteligible la estructura misma del sentido de cualquier objeto cultural (Dallera 2013). Este enfoque se orienta a construir herramientas teórico-metodológicas que permitan reconocer las variantes y las invariantes de sentido y jerarquizarlo. En nuestro caso nos interesa su producción en torno a lo que denomina recorrido generativo para analizar la producción de sentido de los discursos publicitarios en su nivel inmanente.

Como señalamos al comienzo, la pieza publicitaria seleccionada para el análisis es del emprendimiento Manantiales de la DU Grupo Edisur S.A. Las DU son grupos económicos privados que comenzaron a conformarse en los años noventa a partir del desarrollo de formas de producción del suelo urbano novedosas para la época ${ }^{1}$ (Capdevielle 2014). En el año 2003 fundaron la "Cámara de Desarrollistas Urbanos de Córdoba (CEDUC)", entidad dirigida a obtener respuestas gubernamentales a sus principales demandas, sobre todo, aquellas vinculadas a la accesibilidad del suelo. La principal herramienta utilizada para ellos son los Convenios Urbanísticos, acuerdos que implican concesiones sobre alguna normativa a cambio de inversión en obras públicas, Manantiales es un caso paradigmático en este sentido. Este se encuentra en la zona sur oeste de la ciudad de Córdoba ${ }^{2}$. Ofrece diferentes propuestas habitacionales dirigidas a consumidores de poder adquisitivo medio y alto. Para adquirir estos terrenos la DU firmó diferentes Convenios Urbanísticos con el Gobierno Municipal ${ }^{3}$ que le permitieron desarrollar un emprendimiento con dimensiones sin precedentes en la ciudad. A partir de estos acuerdos la empresa tuvo que realizar algunas inversiones en obras e infraestructura urbana que, sin embargo, tuvieron como principal objetivo habilitar el acceso a los servicios públicos exclusivamente a los nuevos residentes de Manantiales. Decimos esto porque otra de las "obras públicas" desarrolladas por Edisur,es un muro de aproximadamente 1,5 km de extensión, en terrenos que pertenecen a Vialidad Nacional, que aísla el emprendimiento de los barrios aledaños.

Para nuestro análisis, seleccionamos la landing page de

\footnotetext{
${ }^{1}$ Nos referimos a countries y barrios cerrados

${ }^{2}$ Ocupa una superficie aproximada de $10 \mathrm{~km}^{2}$ que tienen como límite norte la intersección de las calles Cruz Roja Argentina y Río Negro, y al suroeste más allá de la avenida Circunvalación.

${ }^{3}$ En el año 2008 firma un Convenio que se trató de una modificación normativa que permitió un cambio en los usos del suelo ya que habilitó al desarrollo urbano de una zona que revestía la categoría de Reserva Verde. El convenio fue ratificado por la Ordenanza $N^{\circ} 11.272 / 07$ luego de negociar con Edisur la construcción de 2 dispensarios y una inversión al municipio de alrededor de \$11.600.000. El 29 de octubre de 2014 se aprobó otro Convenio Urbanístico que le permitió a la DU acceder a 563 mil metros cuadrados en la zona suroeste de la ciudad por fuera del anillo de Circunvalación, a cambio de obras de infraestructura y 23 ha. para uso público.
} 
Manantiales:"Realidad que Inspire". Se denomina de ese modo al sitio web al que el usuario llega desde un enlace en una guía, un banner, una página web, etc.; su contenido es más específico que el de una página web y está dirigido a generar contacto directo con el usuario. Decidimos abordar esta landing page como narración ya que nos permite analizar como su despliegue visual también implica un despliegue de generación de sentido y transformaciones en los niveles de análisis. ¿Qué actantes se presentan y de qué modo? ¿Qué objetos de valor propone esta publicidad? son algunos de los interrogantes que guiarán nuestro análisis.

\section{El recorrido generativo de sentido: algunas herramientas para el abordaje del discurso publicitario}

Nos proponemos analizar la pieza publicitaria a partir de los aportes de Algirdas Greimas, específicamente lo que propone como recorrido generativo:

...la economía general de una teoría semiótica (o solamente lingüística), es decir, la disposición, unos con relación a otros, de sus componentes, y ello desde la perspectiva de la generación, lo que equivale a postular que, al ser posible definir cualquier objeto semiótico según el modo de su producción, los componentes que intervienen en este proceso se articulan entre sí según un recorrido que va de lo más simple a lo más complejo, de lo más abstracto a lo más concreto (1980: 194).

Así es que podemos hallar en los objetos significantes dos estructuras: la semionarrativa y la discursiva; en este trabajo nos concentramos fundamentalmente en la primera ya que para el autor constituyen "el nivel más abstracto, la instancia ab quo del recorrido generativo" (Greimas 1982: 196). Sin embargo resulta importante tener en cuenta algunos aspectos de la manifestación del sentido que se da en la enunciación, tales como los actores o personajes, los ámbitos temporales y los espacios en los cuales se desarrolla el relato. La estructura semionarrativa, por su parte, está conformada por dos componentes, el sintáctico y el semántico. Estos, a su vez, presentan dos niveles de profundidad: la semántica fundamental y la sintaxis fundamental; y la semántica narrativa y la sintaxis narrativa.

\subsection{El nivel narrativo: actantes y programas narrativos}

El nivel narrativo nos permite el estudio de la representación antropomorfa de las operaciones de sentido del nivel profundo, es decir, es un "hacer" que presupone un sujeto y al mismo tiempo es objeto de comunicación que circula entre un destinador y un destinatario (Latella 1985). En ella lo conceptual se pasa a lo figurativo, dándole la forma de la acción humana a los componentes del nivel anterior (Dallera 2013). En el nivel sintáctico una de las figuras 
fundamentales es la del actante, unidad sintáctica de carácter formal, anterior a todo vertimiento de sentido; "un actante es lo que es (su ser) más lo que hace (su hacer)" (Dallera 2013). Greimas propone seis roles actancialesdivididos en tres pares vinculados por una relación: sujeto-objeto, donde el sujeto a través de su acción desea establecer un tipo de relación con un objeto que es un signo de valor; destinador-destinatario, unidos por el nexo del mandato; ayudanteoponente que serán aquellos que en el transcurso del relato sirvan a los propósitos del destinador-sujeto. La unidad elemental de la sintaxis narrativa es el enunciado narrativo que existe de dos formas: como enunciado de estado y como enunciado de hacer; el cual, a su vez, definen dos tipos de sujetos, los de estado y los de hacer. Los primeros están en junción (conjunción o disyunción) con objetos depositarios de valores, sólo se los puede establecer como tales en la medida en que están en relación con dichos objetos de valor y participan de universos axiológicos y, los objetos de valor, sólo lo serán en la medida en que actúan como objetos a los que apuntan los sujetos. Los sujetos de hacer, por su parte, son aquellos que operan transformaciones que se sitúan entre los estados, es decir, los enunciados de hacer rigen los enunciados de estado. En este punto Greimas señala que con ello hace referencia a un acto ya que los enunciados de hacer y los enunciados de estado "...no son, pues, más que representaciones lógico-semánticas de los actos y de los estados" (Greimas 1980: 13). Antes de que los sujetos y los objetos entre en relación con las funciones son virtuales, es decir, no son actantes en actos, no están actualizados.

Las categorías antes descriptas se articulan en lo que el autor va a denominar programa narrativo (en adelante PN). Esto es la organización sintáctica del acto, son así la unidad elemental operatoria de la sintaxis narrativa y descansa en la transformación de un estado de cosas a partir de la privación o adquisición que resulta de un predicado de acción (Bertrand 2000). Los PN son el mecanismo encontrado por Greimas para dar cuenta de la narratividad, son los que modelizan la estructura elemental de la acción. Va a proponer cuatro fases para los PN: competencia, performance, manipulación y sanción o reconocimiento. La performance se identifica con la acción humana y aparece como una transformación que crea un nuevo estado de cosas (Latella 1985), es el "hacer" que hace "ser"; es decir, la performance de un actante está orientada a que los otros modifiquen su estado. Para que esto sea posible, con anterioridad, el actante debe poseer ciertas competencias, es decir, se requiere "ser" (querer -hacer o deber -hacer) de determinada manera para realizar la acción (poder-hacer o saber-hacer), si esta competencia recae sobre un actante objeto será un "ser que hace ser" y si recae sobre un sujeto será un "ser que hace hacer" (Dallera 2013). La manipulación, por su parte, es una forma particular de performance que implica que la acción del actante esté destinada a otro sujeto con el propósito de "hacerle hacer algo". La sanción o reconocimiento 
se encuentran al final del PN y por lo general son llevadas a cabo por el actante destinador.

En este punto nos parece necesario mencionar lo que Greimas entiende como modalizaciones es decir, la manera en que quedan afectados el ser y el hacer de los actantes, "...toda modificación de un predicado por otro predicado es definida como modelización..." (Latella 1985). La teoría de las modelizaciones tiene como principal objetivo aportar herramientas que le permitan al analista entender, en toda su complejidad, cómo se estructura el ser y el hacer de los actantes en el recorrido narrativo, nos encontramos con dos estructuras modales básicas (competencia y performance) y cuatro sobre modelizaciones (querer, deber, saber y poder); la combinación de ellas dan como resultado ocho categorías modales que sostienen el abanico de acciones que suceden en el nivel discursivo.

Los PN se inscriben en un marco general de la organización narrativa, el esquema narrativo y presenta como una estructura de alcance transcultural ya que permite "leer a todo el discurso narrativo como una búsqueda del sentido o de la significación atribuible a la acción humana; el esquema narrativo se nos aparece entonces como la articulación organizadora de la actividad humana que erige a esta significación" (Greimas 1980: 11). Este esquema está compuesto al menos por dos itinerarios narrativos: el del sujeto y el del anti-sujeto; que en algún momento confrontan de manera polémica o transaccional. Lo que se pone en juego en esta confrontación son los objetos de valor por lo que el relato se define por la circulación de estos objetos de valor entre los sujetos a través de los distintos PN (Greimas 1980).

La semántica narrativa es la que permite identificar cómo operan los valores virtuales del nivel fundamental y se los actualiza en su junción con los sujetos de la sintaxis de superficie, a partir de las restricciones impuestas a las diferentes combinatorias se decide el tipo de discurso a producir (Latella 1985).

\subsection{El nivel fundamental: eje semánticos y cuadrado semiótico}

La estructura profunda, por su parte, nos permite identificar que, cualquier relato, pondrá en relación componentes de un mismo eje semántico es decir, el sentido se construye a partir de relaciones binarias de oposición. La semántica fundamental tiene un alto nivel de abstracción y analiza el contenido; en este nivel Greimas distingue distintas categorías sémicas que son las susceptibles de ser actualizadas como valores en el nivel antes descrito. La sintaxis fundamental, el aporte lógico relacional a la construcción de sentido, un conjunto de operaciones lógicas que articulan los elementos semánticos que configuran un determinado universo discursivo (Dallera 2013), descubre el modo de existencia y el modo de funcionamiento de la significación. Este nivel se representa a partir de lo que se conoce como cuadro semiótico que es 
un esquema lógico de posiciones: dos ejes de términos contradictorios; dos de implicancia; y las líneas horizontales que representan contrarios

A continuación aplicaremos las categorías analíticas en la landing page "Realidad que Inspire". Esta es una página web diseñada específicamente para convertir visitantes en contactos que, voluntariamente, pasan a formar parte de la base de datos de la empresa ya que, para profundizar la información que allí aparece, deben dejar sus datos. El contenido del sitio está organizado del siguiente modo: presenta la información más importante al comienzo y luego se despliega, en este caso hacia abajo, los distintos argumentos que lo sostienen (InteractiveAdvertising Bureau, s.f.). Dada esta particularidad que presenta el soporte es que planteamos la hipótesis de que el sentido narrativo se va generando a partir de este recorrido espacial que se despliega hacia abajo.

\section{Despliegue Narrativo de la landing page: "Hagamos que la realidad inspire"}

Al ingresar a la página lo primero que aparece esun segmento que en la publicidad interactiva se denomina above the fold, lo que hace referencia a la parte de la página que es visible en el primer impacto, sin necesidad de hacer scroll. Aquí se proyecta un video que es un montaje de tomas sin sonido: la primera toma es un plano aéreo de una urbanización; luego aparece un plano general de "Las siete alcantarillas" 4 ; después, una toma que posee un plano americano de un hombre y una mujer con vestimenta deportiva, corriendo en un espacio verde de izquierda a derecha; luego aparece un plano medio de una niña de pelo castaño y vestido de cuadros color rojo, con globos en una de sus manos, corriendo por un espacio abierto con vegetación; la toma siguiente muestra un plano medio con ángulo contrapicado de un hombre y un niño, ambos de cabello claro, acariciando a un perro de raza Golden Retriever, en un espacio abierto arbolado. Aparecen, también, cuatro tomas sucesivas que muestran primeros planos de una joven, dos hombres y una niña, todos sonriendo a la cámara, el viento hace ondear sus cabellos y están ubicados en un espacio abierto en el que se puede ver la vegetación de fondo del cuadro. En todas las tomas hay iluminación natural, inclusive, en algunas de ellas, se juega con el efecto de contraluz. En la parte inferior del video aparece un marco que combina los colores blanco, verde y azul que son los que se encuentran en el logo de la empresa; en el ángulo superior derecho se observa el logo de Edisur $y$, sobre el margen izquierdo, la frase, con letra imprenta mayúscula y en color blanco: "hagamos que la realidad inspire".

Si bien no hay referencia explícita del lugar en donde se realizan las

\footnotetext{
${ }^{4}$ Las Siete Alcantarillas es un acueducto construido a fines del siglo XIX, parte de una de las obras de ingeniería más importantes de Córdoba. Están emplazadas en un lugar que fue "puesto en valor" por la empresa EDISUR.
} 
acciones puede interpretarse, por lo que se muestra, que es el "interior" de Manantiales; decimos "interior" porque, aunque las tomas sean de exteriores, como ya dijimos, la urbanización está separado por un muro de los barrios aledaños y el ingreso es limitado. Las marcas temporales están dadas por el tiempo verbal de la frase: presente.

El contenido de este segmento se articula en función del enunciado "hagamos que la realidad inspire". El lexema "inspiración" puede tener, al menos, dos sememas posibles: el acto de hacer que el aire exterior ingrese a los pulmones de un individuo; pero también, un estímulo espontáneo orientada a la creación. Sin embargo, las propiedades atribuibles a este término en este texto son (observadas principalmente en las diferentes imágenes) actividad, alegría, belleza, disfrute, felicidad por lo que podemos decir que el semema utilizado es el segundo. A partir de esto nos interesa comprender el modo de funcionamiento de la significación que, como mencionamos antes, se construye a partir de articulaciones lógicas: la inspiración, en tanto estímulo espontáneo, es contraria al esfuerzo y el entrenamiento; y contradictoria a la no inspiración. La inspiración implica un no esfuerzo y entrenamiento, mientras que si hay esfuerzo y entrenamiento no hay inspiración

La "inspiración" se convertirá en el valor que circula en este PN. El verbo imperativo "hagamos" nos permite identificar un mandato y, por tanto, un sujeto-destinador que adjudica el "deber hacer" a un destinatario para que éste pueda hacer que la realidad inspire. Lo interesante es que el verbo está en plural, por lo que, estaríamos frente a una acumulación actancial ya que los personajes del audiovisual y Edisur serían, al mismo tiempo, destinadores y destinatarios; luego de adquiridas las competencias, el sujeto de hacer, orienta su performance a un objeto, la realidad, hay un "hacer que hace ser", actúan sobre la realidad y le atribuye el valor de la inspiración.

\subsection{PNB: "Seamos el ejemplo"}

El mensaje de la landing page se despliega hacia abajo, luego del abovethefold, descrito anteriormente, nos encontramos con otro segmento que se articula en función del siguiente texto:

\section{"SEAMOS EL EJEMPLO}

El ejemplo es la mejor forma de transformar el lugar y la vida que elegimos vivir; por eso, en nuestros desarrollos aplicamos ese principio, el de construir todos los días la realidad que queremos ver."

Luego del texto aparece nuevamente, aunque ahora en imagen fija, el plano medio con ángulo contrapicado de un hombre y un niño, ambos de cabello claro, acariciando a un perro de raza Golden Retriever, en un espacio 
abierto arbolado; sobre la imagen encontramos la siguiente leyenda: "En Edisur creemos que el ejemplo trasciende". El mensaje se desarrolla hacia abajo en cuatro subtítulos, cada uno acompañado de una imagen y un breve texto (que tienen la opción de "leer más" a partir de un hipervínculo): "Estamos comprometidos con la sociedad" acompañado a su derecho por una imagen aérea de una urbanización; "Creamos oportunidades" y en el margen izquierdo aparece una imagen de un hombre y una mujer con indumentaria de ciclistas, andando en bicicleta por una calle en un espacio que parece ser un parque; "Cuidamos el medioambiente" y a su derecha un primer plano de un hombre caucásico sonriente; y por último, la frase "Hacemos que la ciudad avance" y a su izquierda una imagen con un plano general de un espejo de agua.

En el plano del contenido podemos ver que la composición categorial de "lo ejemplar" está constituido por los semas: transformación del espacio, elección de modo de vida, construcción de la realidad. En este PN "Io ejemplar" es sancionado positivamente, supone la circulación de objetos de valor positivos y la invitación a que el o los PN de uso que promueven esa conjunción con valores positivos sean imitado. Se utiliza nuevamente el nosotros inclusivo al comienzo, la bajada de la frase y la leyenda sobre la imagen nos permite ver claramente que Edisur es quien realiza estos programas narrativos que deberían ser imitados por otros sujetos. De esta manera, Edisur aparece como sujeto de hacer que pone en conjunción a determinados sujetos de estado con valores positivos.

A continuación, se observan las manifestaciones que se corresponden con PN de uso que describen la conjunción de Edisur con los valores positivos y establecen un deber hacer para que determinados sujetos de estado se pongan en conjunción con valores positivos que promueven la realización del PN de base.

\subsubsection{PN1: "Estamos comprometidos con la sociedad"}

En primer lugar nos encontramos con la frase "Estamos comprometidos con la sociedad": en el plano del contenido vemos que el "compromiso social" está conformado por los semas transparencia, responsabilidad social empresaria y sustentabilidad; en la sintaxis fundamental lo que se articula para configurar el sentido sería entonces la contradicción entre ese compromiso social que, como dijimos antes, implica un desarrollo sustentable, transparente y responsable en oposición a un desarrollo insostenible, irresponsable y corrupto. Entonces este PN de uso supone un "deber hacer", el sujeto-destinador, que no está explícito, implica un actor colectivo que debe poner al sujeto-destinatario en conjunción con un valor positivo como lo es el "compromiso social", "manda" tener un desarrollo transparente, sustentable y responsable. El destinatario es en un primer momento Edisur como el personaje que asumió el rol de sujeto- 
destinatario y adquirió esas competencias y manipula al destinatario para "hacer hacer".

\subsubsection{PN2: "Creamos oportunidades"}

El segundo PN de uso que aparece es "creamos oportunidades": en el nivel semántico los semas que constituyen la "oportunidad" son el trabajo, la capacitación de los vecinos y PyMES y el crecimiento conjunto. La configuración de significación se da con la contradicción entre oportunidades para la sociedad y oportunidades sólo para Edisur que implica crecimiento sólo para la empresa y no conjunto.

En este PN de uso, en primer lugar, Edisur asume el rol de sujeto de hacer que sabe y puede realizar la prueba y modifica el estado de cosas. A su vez, es quien ocupa el rol de sujeto-destinador ya que la ambigüedad del enunciado "hagamos entre todos que estas oportunidades se consoliden y se sigan multiplicando para crecer juntos" coloca Edisur como un sujeto que pone a otros en conjunción con un objeto modal: poder para hacer figurativizado a nivel de superficie como oportunidades

\subsubsection{PN3: "Cuidemos el ambiente"}

En el apartado "cuidemos el medio ambiente" aparecen los semas crecimiento ordenado de la ciudad y cuidado, promoción y aprovechamiento del medio ambiente; en la sintaxis fundamental podemos ver que la contradicción se establece entre cuidado del medioambiente y destrucción del medio ambiente, esto último implica el crecimiento desordenado de la ciudad y el desinterés o descuido del ambiente.

En este PN de uso se promueve la conjunción con los valores sancionados positivamente: "crecimiento ordenado" $\mathrm{y}$ "fomento, cuidado y aprovechamiento del medio ambiente". Edisur tiene las competencias, es un "ser que hace hacer" a otro sujeto. Nuevamente aparece la manipulación el "hacer hacer" que a nivel de superficie es "ser guardián de la naturaleza". Es aquel que hace que "Todos" (los destinadores) entren en conjunción con el cuidado del entorno natural único (de Manantiales).

\subsubsection{PN4: "hacemos que la ciudad avance"}

Por último, el PN de uso "hacemos que la ciudad avance" se basa en la categoría "crecimiento y progreso de la ciudad" cuyos componentes sémicos son la recuperación, revitalización, conexión y urbanización. Así el avance de la ciudad es contradictorio con el retroceso que implica el deterioro, abandono, desconexión y el descuido.

El valor sancionado positivamente en este PN es el "desarrollo", Edisur es 
el sujeto de hacer, hace que el sujeto de estado, ciudad, entre en conjunción con el objeto positivamente valorado, lo cual habla de que su capacidad (benéfica para hacer) sea tal que consigue beneficiar a la ciudad entera y también al medio ambiente.

\subsection{Doble programa narrativo}

Es posible decir tras este análisis que en la landig page del emprendimiento Manantiales del Grupo Edisur nos encontramos con dos PN: uno que promueve la conjunción con valores positivos que son "ejemplares" en el que, si bien al comienzo aparece el nosotros inclusivo, se refiere sólo a la DU. Ellos son quienes, a través de los distintos PN de uso, adquieren las competencias y saben y pueden realizar las distintas acciones para obtener una sanción positiva y ser "el ejemplo" del desarrollo urbano.

El otro PN que identificamos es el que se presenta en el primer segmento de la plataforma. en él, a nivel discursivo, se utiliza la estrategia del nosotros inclusivo "la sociedad en su conjunto" y exclusivo, Edisur. Luego del análisis nos preguntamos si "hagamos que la realidad inspire" no abre la creación de un nuevo programa narrativo, siempre ambiguo, en el que Edisur se incluye y posibilita que todos adquieran sus competencias, sean el ejemplo y hagan que la realidad inspire o sean quienes asumen el rol de sujetos de hacer desarrollando el PN transformando a los sujeto de estado, los consumidores.

\section{Consideraciones finales}

El análisis realizado tenía como objetivo abordar una de las piezas del dispositivo publicitario de la DU Grupo Edisur, con el fin de intentar comprender la estructura del sentido de la landig page "realidad que inspire". Para ello retomamos las herramientas de análisis que aporta la propuesta de AlgirdasGreimas en lo que respecta al recorrido generativo de sentido (1980), planteando la hipótesis de que en este caso, el sentido se iba generando al mismo tiempo en el despliegue visual de la página web.

En base a esto, en principio encontramos que al ingresar a la landing page, se construía el PNB, y al desplegar la página, distintos PNU iban dando cuenta de cómo llegar a ese PNB. En relación a esto, identificamos dos grandes núcleos de sentido. Por un lado, posiciona a Edisur como "el ejemplo" del desarrollo urbano, una empresa que elige un modo de vida y construye la ciudad queremos ya que la realización del PN que solo suponen la conjunción con valores es una estrategia de manipulación ¿quién no querría la conjunción con valores positivamente calificados? ¿Quién no querría "cuidar" el medio ambiente, ser una DU transparente, responsable y comprometida socialmente, $y$, a su vez, hacer de la ciudad una "ciudad grande", que avanza y se desarrolla ordenadamente? La estrategia general de la publicidad busca persuadir, dar a 
conocer como se hace para ser ejemplar e invita a sumarse al emprendimiento para que juntos "seamos el ejemplo, "transformemos la ciudad" y "hagamos que la realidad inspire".

Así Edisur ocupa en todos los casos el rol de sujeto de hacer, hace que no solo la ciudad se desarrolle sino la sociedad toda. Por eso es que Manantiales es, paradójicamente, el camino más certero para cuidar la naturaleza, recuperar espacios abandonados y generar trabajo para los vecinos; todo producto de la intervención de la empresa en la ciudad.

$\mathrm{Si}$ el objetivo del dispositivo para Agamben no es otro que el gobierno y la adecuación de los gestos y las conductas, podemos ver cómo los sentidos generados, en uno de los elementos que lo constituyen, aporta en ese sentido. Aquí se propone no sólo un modo de ser DU sino una particular forma de intervenir la ciudad. Una intervención que, a su vez, permite el desarrollo pleno de la calidad de vida, y esto a partir de una oferta comercial que no solo haga justicia a la pluralidad de actividades necesarias para la vida, sino que además permita el desarrollo de la participación en la comunidad, todo ello impulsado por Edisur.

\section{Bibliografía}

AGAMBEN, G. 2014 ¿Qué es un dispositivo? Buenos Aires: Adriana Hidalgo.

BAJTíN, M. 1998. Estética de la creación verbal. México: Siglo XXI.

BOITO, M.E; Espoz, M.B y Michelazzo, C. 2015. "Una relectura de la noción de espectáculo a propósito de las experiencias en los entornos tecnológicos" en Sociedad y Discurso. №27. https://journals.aau.dk/index.php/sd/article/ view/1252

CAPDEVIELLE, J. (2014). "Cambios y continuidades de los grupos "desarrollistas" y su incidencia en la ciudad de Córdoba, Argentina. VII Jornadas de investigación en Antropología Social. Facultad de Filosofía y Humanidades, Buenos Aires.

DALLERA, O. 2013 “II. La teoría semiológica de Greimas”, en Zecchetto, Victorino (Comp.) Seis semiólogos en busca del lector. Buenos Aires: La Crujía. 151-190.

GREIMAS, A. J. 1980 "Las adquisiciones y los proyectos", en Courtès, Joseph. Introducción a la semiótica narrativa y discursiva. Metodología y aplicación. Buenos Aires: Hachette.

GREIMAS, A. J. y Courtès, J. 1982 “Generativo (recorrido)”, en Semiótica. 
Diccionario razonado de la teoría del lenguaje. Madrid: Gredos. 194-197.

LATELLA, G. 1985. "Primera parte. La teoría semiótica de A.J. Greimas", en Metodología y teoría semiótica. Buenos Aires: Hachette. 15-55.

\section{Corpus}

Edisur. "Hagamos que la realidad te inspire" (Landing page). Disponible en: http://www.grupoedisur.com.ar/landings/realidad-que-inspire/ [visto el 22 de agosto de 2018] https://web.archive.org/web/20180326025609/http://www. grupoedisur.com.ar:80/landings/realidad-que-inspire/ [visto el 28 de agosto de 2019]

InteractiveAdvertising Bureau." Landing page". Disponible en: http://www.iab. com.uy/glosario/ 


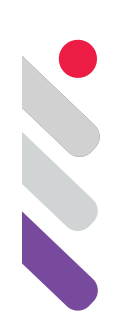

\section{Smarthphones y auriculares para inscribir la ciudad como escenografía.}

DOI: 10.24308/IASS-2019-5-013

Mónica Berman

Facultad de Ciencias Sociales (UBA). IIET (DGEART. Ministerio de Cultura. CABA),

Argentina.

monicaberman@gmail.com

\section{Usos desviados/experimentales de smarthphones y auriculares}

En la semiótica de las mediatizaciones, en general, se analizan los usos frecuentes y habituales, ahora bien, ese conocimiento sirve de base para observar aquello que podría considerarse un "uso desviado". La experimentación artística suele plantear este tipo de uso que interesa considerar en el presente trabajo.

En el marco de la investigación del proyecto UBACyT Letra, Imagen, Sonido. Convergencias y divergencias metodológicas y teóricas en el estudio de las relaciones entre los medios y el espacio urbano, dirigida por el doctor José Luis Fernández, se analiza el uso de smarthphones y su asociación con los auriculares. Una serie de opciones se interrogan por sus posibles usos cotidianos. Aquí se focalizará en el lugar que remite a "otros", espacio que las variables dejan abiertas para introducir aquello que no suele preverse.

Combinación de usos excepcionales; cuando se experimenta, como en estos casos, se ingresa en una zona de desplazamiento. Se producen, al menos, dos desplazamientos centrales: el lugar del espectador no es fijo sino que recorre la ciudad o una porción de ella, y en ese acto deviene de espectador en intérprete en un juego bastante complejo pero además, todo lo que es del orden de lo cotidiano se transforma "escénicamente" a partir de la intervención de las mediatizaciones. Es la mediatización la que hace devenir la ciudad en escenografía, a los otros en co-intérpretes y co-espectadores y al mismo interesado lo lleva a asumir un rol que oscila entre el protagonista y el obediente que se deja guiar por una serie de instrucciones, una analogía con el prosumidor para decirlo de manera económica. 
Ahora bien, muy lejos se está de pensar el teléfono y los auriculares como meros instrumentos sino como condiciones de producción de este tipo de discurso que tiene lugar en función de sus características particulares que generan esa posibilidad.

Se trabajará con dos casos puntuales, Remote Buenos Aires de Rimini Protokoll y Perfil Bajo de Ezequiel Hara Duck. El primer caso es el de un grupo que realiza esta propuesta en diversas ciudades del mundo y se focalizará la que presentó en esta ciudad en el FIBA 2017. El segundo es una propuesta de un director argentino que hace teatro para un solo espectador pero el modo en el que se constituye en espectador/intérprete es a través del smarthphone.

El objetivo de este trabajo es analizar otras consecuencias, indirectas o menos frecuentes de la aparición de los auriculares y de los smarthphones. Si bien, el punto de partida es el planteo de José Luis Fernández en el que vincula unos y otros como parte de un sistema, en este análisis se buscará escindirlos y por eso la selección de estas dos propuestas para el brevísimo corpus: en una se trabaja con auriculares sin Smartphone y en la otra, Smartphone sin auriculares.

Remote Buenos Aires es una propuesta de Rimini Protokoll, un colectivo de directores teatrales que se conocieron en los años 90 mientras estudiaban en el Instituto de Ciencias del Teatro Aplicadas en una universidad alemana, una escuela de elite del teatro alemán de vanguardia. Rimini Protokoll está integrado por Helgard Haug, Stefan Kaegi y Daniel Wetzel, quienes bajo este sello desarrollan sus proyectos.

El cruce permanente entre realidad y ficción es característico del colectivo. Trabaja a partir de investigaciones de lo más diversas y siempre vinculadas a lo "real". Describir su trabajo en general implicaría una ponencia exclusiva. Digamos sí que Remote + (nombre ciudad) es la fórmula que utilizan para uno de sus trabajos que ellos mismos sostienen que está articulado entre el teatro documental y el site specific. Más de 35 ciudades han sido objeto de Remote. Jörg Karrenbauer, creador de la pieza junto con Stefan Kaegi describe que un grupo de unas 40 personas con auriculares individuales van por la ciudad en cuestión, en grupo. Por supuesto que en el hilo de la historia están el paseo dadaísta, el deambular surrealista, las derivas de los situacionistas, etc.

En este trabajo se pondrá en relación la propuesta con un universo no escénico. Por supuesto que para pensar la ciudad como escenografía el teatro callejero se inscribe en primer plano o las intervenciones urbanas, para dar un ejemplo vernáculo, como las de La Organización Negra; y que para reflexionar sobre el trabajo con auriculares se puede analizar Interiores, de Mariano Pensotti (Centro Cultural Rojas, 2007) o The quiet volume de Ant Hampton \& Tim Etchellsc 2010? (en Buenos Aires se presentó en el marco de Ciudades Paralelas y luego tuvo "funciones" en el FIBA en 2017), o los trabajos de BiNeural-MonoKultur compañía fundada en 2004 que"fueron invitados por 
el grupo alemán Rimini-Protokoll a participar en el ciclo "Mit Kopfhörer und Feldstecher" ('Con auriculares y largavista') organizado por el teatro Hebbel (Berlín, Alemania): el público estaba en un segundo piso de un edificio y miraba la performance que se desarrollaba en la calle con largavista y escuchaba con auriculares." Solo para señalar, con algunas menciones sueltas y escasas en relación con la ¿totalidad?De ningún modo son los únicos.

Abandonado el universo escénico, se puede hacer alguna aclaración más: este trabajo tiene un doble desafío porque las disciplinas que se pondrán en relación suelen ir por caminos paralelos. Quienes se dedican a las mediatizaciones no trabajan, en general, con lo escénico (aunque sí con las artes visuales de manera frecuente) y quienes analizan lo vinculado con lo estéticoescénico eluden los aportes de la semiótica de las mediatizaciones.

José Luis Fernández (Fernández, 2017) “trata a algunas plataformas como interfaces, es decir como sistemas de combinación de la vida social y de sus intercambios discursivos" en un gesto de clasificación plantea que responden a cuatro tipos: "las informativas, las logísticas, las broadcasters- ofrecen diversas posibilidades de recepción equivalente al broadcasting- y las de interacciones múltiples que organizan buena parte de la vida social."

Este primer ordenamiento propone un lugar en el que puede incluirse Remote $X$. Una propuesta que a priori parecería interactiva porque propone transeúntes desplazándose por la urbe, en términos de mediatización se construye desde el lugar del broadcasting, los textos sonoros han sido grabados a priori y responden al modelo estrella: un emisor para múltiples receptores (claro que no son infinitos, ni indeterminados, han dejado su documento a cambio del aparato que les permite participar en este evento).

Fernández (2017) afirma que el“fenómeno plataforma es un nivel de intercambio mediático múltiple que obliga a revisar no solo la definición de medio sino (...) la de redes o medios sociales. Recorrer las calles de una gran ciudad implica hacerlo entre múltiples plataformas de comunicación en la vía pública (...)"

El autor afirma que (Fernández, 2017) "Vivir en plataformas no es tanto, entonces, un nuevo y fundacional espacio de intercambios mediatizados sino un nuevo modo a agregar para comprender la vida social en la que la semiótica y la sociosemiótica de las mediatizaciones se ven nuevamente desafiadas."

Sostiene además que es factible pensar la idea de "Plataformas ampliadas: smartphones + auriculares pensado como un caso de vidas en plataformas" para plantearlo en estos términos "incide el estudio previo de medios de sonido, tensiones entre movilidad y mediatización."

José Luis Fernández afirma que el espacio urbano está lleno de personas que lo recorren con auriculares, estos "audionautas" están de manera permanente a la vista de todos y sin embargo, no devienen objeto de estudio 
¿qué queda para lo menos visible? Se pregunta. Si hay algo que sucede cuando Remote tiene lugar es, constituir un conjunto de "audionautas" moviéndose en una ciudad, en bloque, y realizando acciones cotidianas como caminar o extraordinarias como pararse frente a una bóveda o bailar en algún espacio público... Devienen parcialmente visibles ¿despiertan preguntas en los transeúntes que no se plegaron al juego performático?

Sin duda, Remote Buenos Aires se plantea como un sistema de intercambio discursivo mediático con base fuerte en la mediatización de sonido: se producen, emiten, distribuyen y reciben textos sonoros. Todo el intercambio discursivo pertenece a esta materialidad. Es cierto que no estamos como en la radio (para pensar el modelo fundante del broadcasting) sin una incidencia de lo visual pero esto está determinado de manera unívoca por lo sonoro. Y el discurso es del orden de lo sonoro. Armando el hilo de la historia la radio "convive en el tiempo real con los oyentes y construye una atmósfera de actualidad rabiosa en común con su audiencia se genera un efecto de imprevisibilidad que se opone a la discursividad guionada y pre producida antes de su emisión" Por supuesto que acá el juego es relativamente ficcional. Porque lo que se va a producir es un desvío de lo actual, lo sonoro (salvo en algunos tramos) va a proponer ir casi en contra de lo que se ve, lo que se habita, lo que se recorre.

\subsection{El modelo de la audioguía}

Si hay que plantear un modo mediatizado en términos auditivos de observación/orientación visual, de organización de recorrido el modelo es la audioguía. ${ }^{1}$ Acoustiguide nace en 1957 en Hyde Park para armar un trayecto explicado que no es del orden de los museos.Pero sin duda lo que más se desarrollo fue la existencia de audioguías en los museos.

¿Qué es una audioguía? Dispositivos que se usan tanto en espacios abiertos (ciudades) como cerrados (museos) para brindar información sobre objetos o lugares relevantes que el visitante puede encontrar allí.

Sin duda, el dispositivo señala pero se produce un desvío importante: no se trata de un visitante sino de un nativo. El desafío es ver de otro modo la ciudad cotidiana. En sentido estricto, Remote se maneja a través de una audioguía, literalmente.

A cada objeto o lugar le corresponde una parada y éstas están organizadas según algún tipo de recorrido previsto. El gran aporte de las paradas numeradas es que cada visitante imprime su propio ritmo. Remote rompe deliberadamente el ritmo propio, incluso, tematiza la imposibilidad de que el rebaño o la manada,

\footnotetext{
${ }^{1}$ Es imposible mencionar "Audioguía" y no hacer referencia a una propuesta ficcional en la que la audioguía es un elemento constitutivo, desviado pero brillante en la obra de Rafael SpregelburdApátrida, 200 años y unos meses y la cuestión sonora a cargo de Federico Zypce, estrenada en 2010 en Buenos Aires.
} 
como denomina al conjunto de participantes pueda imprimir su ritmo: es obligado a asumir una velocidad ajena, debe acomodarse, todo el tiempo.

La primera audioguía de museo, esa experiencia móvil, es de 1952 (Stedelijk, Museum Amsterdam) cada visitante podía controlar su experiencia individual mediante el acceso a una información personalizable a partir de una radio de onda corta.

En "Una nueva mirada a una vieja amiga: reevaluar el sistema de audioguía del Met" de Laura Mann y Grace Tung plantean que este dispositivo permite navegar el museo conceptual y físicamente, ayuda a encontrar tesoros y brinda contenidos en el propio idioma.

El sistema de Rimini Protokoll también permite navegar tanto de manera física como conceptual la ciudad, física porque en sentido estricto funciona como instructivo de orientación, indica hacia dónde dirigirse, cuándo cruzar la calle, subir o bajar escaleras, entrar o salir de un cementerio, un hospital, una iglesia, un shopping, un subte y también la manera de hacerlo: correr, detenerse, esperar, amucharse, bailar, moverse, caminar para atrás, en fin. Con respecto a lo conceptual cada una de las paradas inscribe una reflexión, a veces vinculada con el objeto frente al que se detiene, otras veces, deliberadamente se elude el vínculo lineal. O se lo retoma mucho más tarde. Se plantea un recorrido por un hospital, un rato largo más tarde, en el subte y en relación con la cercanía entre el rebaño, quien habla dice que éste es un buen momento para el contagio si alguien se trajo alguna bacteria del hospital. La referencia es tardía e inesperada. Extemporánea. Y en sentido estricto no tiene que ver con el subte. Una recuperación de un recorrido pasado.

Otro rasgo de las audioguías de los museos es la propuesta diversa: hay varios tours en función de los intereses de los visitantes. Buenos Aires Remote suele proponer el movimiento en grupo pero en algunas ocasiones lo quiebra: cuando los participantes deben decidir si son más racionales o mássensibles, cuando van sacando grupos de la iglesia, cuando divide a las personas en el shopping, cuando hace devenir a los que bailan en observadores no bailantes de los otros bailarines. No hay, en principio, recorridos distintos pero sí recortes. La inscripción del aislamiento, de establecer una frontera.

Las audioguías reales pugnan por armar un itinerario estructurado de 'destacados' junto con la necesidad de flexibilidad y variedad es muy interesante contrastar la funcionalidad con el site specific en el que el concepto de "destacados" es relativo al recorrido que hace el artista extranjero en una ciudad ajena, a las posibilidades de desplazamiento, a las restricciones de producción, ¿autorizan a ingresar a determinado hospital, recorrerlo, hasta dónde? ¿autorizan entrar a una iglesia, qué se puede hacer o no? ¿autorizan a subir a un edificio para cerrar con la vista panorámica de la ciudad? En un museo las personas hacen más o menos las mismas cosas. En el marco de Remote, no. 
Marcela Rosemberg afirma que "El uso de la audioguía crea una experiencia inmersiva, aísla al usuario del entorno y de las demás personas" eso que sucede en un museo, en la experiencia Remote se inscribe de manera similar por el dispositivo, el auricular aísla en términos sonoros (cuando se sube al subte advierten que la señal puede interrumpirse e indican cuál es el modo de operar con el aparato y sugieren -¿u ordenan?- subir el volumen para que el sonido propio del subte no interrumpa la experiencia que ellos proponen) ahora bien, en términos visuales, el auricular es el signo de la pertenencia. El rebaño se mueve siguiendo a los que portan ese objeto, no hay ningún otro elemento que permita que el conjunto permanezca unido.

Entre los textos sonoros hay una serie interesante que es la que prevé los inconvenientes: la lluvia, el subte demasiado lleno, los problemas técnicos. Los guías acompañan al rebaño y son los que disparan los audios. Por eso el momento de cruzar o no o cualquier percance están siendo monitoreados por personas que acompañan a los que viven la experiencia Remote.

Para cerrar, arbitrariamente, con este objeto se describirá una acción puntual: convertir al colectivo en espectadores "Un lugar que los une a todos es el teatro. Sentate. Buscá un buen lugar. Pero dejá lugar a los transeúntes. Cuando todos se hayan sentado va a empezar la obra. Silencio por favor. La obra está por empezar. La escenografía muestra (...)" y ahí viene la descripción detallada del sitio en cuestión. Todo lo que es ciudad cotidiana deviene en escenografía a partir de la descripción sonora. Incluso dirán que los autos y los colectivos son empujados por cuerdas invisibles. Luego piden, como corresponde, el aplauso. Cuarenta personas, con auriculares, sentadas en las escaleras de la ciudad, al unísono aplaudiendo a la nada.

\subsubsection{En primera persona Remote Buenos Aires}

El día que describiré empieza de un modo particular. La cita es en la puerta del Cementerio de Recoleta. Cuando llego hay un grupo importante de gente. No, no está esperando el comienzo de la obra sino que es parte de una ceremonia religiosa. Están en un responso. El Cementerio se presenta en toda su dimensión de cementerio. Así nos recibe, ese día, Remote.

El recorrido parte del Cementerio de Recoleta. La organización intercambia documentos por auriculares y equipos de recepción. Nos van a acompañar todo el recorrido. No, van a hacer mucho más que acompañarnos pero ya lo veremos.

Nos indican un lugar de reunión unos pasos más adelante. A medida que nos vamos alistando nos juntamos. El lugar propone armar un círculo, la geometría espacial nos lleva a acomodarnos de ese modo y podemos, si queremos vernos las caras.

Nos avisan. Ya debería abandonar el plural. Porque cada uno es interpelado en sus oídos. Avisan que la experiencia está por empezar. Las 
primeras intervenciones son instruccionales. Qué hay que hacer si se corta la conexión, cuál debería ser en qué lugar debería estar el auricular derecho, izquierdo.

El recorrido nace en el cementerio. Cada uno debe elegir una tumba. El pedido es que si conseguimos que sea propia, mejor, me dicen que la observe, que me fije de quién es, que me pregunte si es lujosa. Una casa para los muertos. Luego nos volverán a reunir. En algún momento no sé si es ahora, antes o después nos dicen que somos pocos para ser una ciudad y muchos para ser una familia. Nos va a llamar rebaño. Se va a proponer como pastor. Un pastor guía. Es algo más que el número de integrantes (digo yo).

Luego vendrá el camino por el cementerio, las tumbas serán los mojones, la indicación de por dónde doblar, por donde seguir, por supuesto que no son solo indicaciones de movimiento sino reflexiones. Y por supuesto, ficción. La construcción de quien enuncia. Que dice que es un software que no tiene cuerpo. Hacemos el camino que no puede hacer.

Nos hace caminar. Nos hace detener. Nos confunde un poco. Nos clasifica. Nos organiza.

Saldremos del cementerio con sus indicaciones. El rebaño irá en conjunto por un rato. Mirando lo que nos dice que mire. En cada indicación hay un recorte. Una focalización. Nos va a dividir. Racionalidad/sensibilidad. Derecha/ izquierda. Me pierdo un poco las instrucciones quedo de un lado sin saber bien por qué. Pide que miremos a los otros. Los otros nos miran, en qué nos parecemos. ¿Algún grupo es más grande? ¿Más chico?

Vamos a terminar frente a un Hospital el Rivadavia. Cuando entramos está vacío. Nadie atiende, nadie espera. Al oído nos subrayan lo que vemos y nos preguntan si no hay nadie enfermo. Vamos a hacer un recorrido. Aparece la pregunta de quiénes se atienden en un hospital como éste. Nos preguntan si nos atenderíamos acá. La respuesta que prevén es "No" somos un montón de burguesitos haciendo un recorrido por un hospital que nos resulta ajeno. Nos subrayan esa ajenidad. Sino no estaríamos aquí. Vamos por un pasillo, nos dicen que de un lado está el pabellón de psiquiatría, del otro el de cirugía plástica. Nos hacen detener mirar para un lado y para otro. Nos señalan unos altares. Nos preguntan ¿ciencia o religión? ¿En qué creés más?

Dejamos atrás el hospital nos dicen que podemos estarnos llevando bacterias.

Nos hacen cruzar las calles, las avenidas, una y otra vez. Nos piden confiar. Nos dicen que lo hagamos juntos. Nos piden que esperemos las instrucciones. En algún momento nos dicen que el semáforo nos disciplina. Pienso que somos cuerpos disciplinables y no por el semáforo sino por las instrucciones que seguimos a través de los auriculares. Y esto podría seguir hasta el final. 


\subsubsection{Teatro para un solo espectador con Smarthphones}

Perfil bajo es teatro para un solo espectador. Sin embargo, no es la primera ni única propuesta concebida de este modo. La elección tiene que ver con algo muy particular (además de lo atractivo que es el proyecto) si el candidato a intérprete/espectador no tiene redes sociales no puede ser parte de la experiencia. Porque para armar la propuesta el director y/o su asistente stalkean al sujeto en cuestión porque Perfil Bajo se arma a medida.

En la ciudad de Buenos Aires las actividades creativas y culturales están al acecho. Un transeúnte puede convertirse en un actor; una calle o una plaza o tal vez un lugar donde habitualmente se compra o se vende, puede transformarse en escenario.

"Perfil bajo" es una frase hecha. Las frases hechas no necesitan explicación porque las explicaciones cuando se convierten en redundantes solo sirven para oscurecer. La propuesta escénica en cuestión porta ese nombre y lo hace con una precisión inefable.

El lugar del espectador suele ser un lugar de "perfil bajo", en general (estadísticamente hablando) está en una sala a oscuras percibiendo lo que otros, actores o intérpretes, llevan a cabo. No es difícil afirmar que la propuesta que lleva adelante Ezequiel Hara Duck es del orden de lo escénico: es cierto, hay un juego de desplazamiento en el lugar del espectador (que a su vez es necesariamente observado y seguido por alguien que construye la ficción, que le construye la ficción para él, de manera exclusiva.)

El trabajo que llevan adelante conlleva un riesgo para los hacedores: el de tener funcionando la imaginación y las herramientas de manera aceitada y dinámica. Porque puede haber imprevistos, incluso propuestos por el propio espectador.

Los requisitos fundamentales son dos: tener un celular por donde llegarán los discursos verbales y no verbales que orientan un porcentaje importante del trayecto (la propuesta es básicamente instruccional) y redes sociales, que son la carta de presentación del espectador (si no hay redes sociales es imposible armar un recorrido único para un espectador único). Los espectadores ideales deben tener entre 18 y 60 años y ganas de pasarla bien. Es una actividad que implica un recorrido.

$\mathrm{Si}$ bien todas las propuestas escénicas tienen ciertos rasgos que las convierten en únicas (sí, como cada función en el teatro, solo que llevado al extremo), el espectador redobla el concepto de ser activo (pero como la "obra" está armada para cada uno el nivel de actividad está programado en función de quién seas y cómo seas), se pone en juego, en simultáneo, la "escritura ficcional" sobre un espacio de la ciudad - hay un armado de una historia, un relato, un recorrido- pero a la vez, hay una zona de improvisación muy bien manejada. 
Las implicancias que tiene exceden largamente lo que se puede decir de manera concreta: por una simple razón, la experiencia es personal. Quien escribe hizo un recorrido, vivió ciertas cosas, desafió ciertos retos pero desconoce qué es lo que hicieron otros.

Cada intérprete/espectador (acá la noción de prosumidor es pertinente al menos, en términos metafóricos) interactúa, recibe instrucciones y acciona. El universo discursivo no atraviesa únicamente la mediatización puesto que puede haber indicaciones de búsqueda de un papel, en un banco, en un libro, una lectura de un texto ajeno a la construcción de este dramaturgo que, así como convierte en escenografía la porción de la ciudad en la que se deambula, convierte en textos dramáticos ciertos textos preexistentes.

Los hacedores son muy cuidadosos con los espectadores, desde el principio insisten en que no serán expuestos a situaciones desagradables, construyen la confianza para que uno se deje llevar por el juego, un juego armado con inteligencia, en el que la sorpresa es ¿̇y cómo saben esto de mí? Lo lúdico se hace presente en primer lugar y las preguntas que se disparan quedan resonando largo tiempo porque el espectro incluye desde una especie de búsqueda del tesoro en algún universo acotado hasta la reflexión de la ciudad como escenografía y los propios actos como la escritura de un relato citadino, dictado por alguien que no hace más que soplar un texto dramatúrgico.

Dos propuestas escénicas que convierten a la ciudad en una instancia escenográfica, auriculares y Smartphone, ¿mediante?

Perfil bajo está dirigida por Ezequiel Hara Duck y Brenda Taubí, es su asistente de dirección.

\section{Bibliografía}

FERNÁNDEZ, J. L. 2017. "La vida en plataformas: auriculares + smartphones". En: Pardo Abril, N. 2017. Semióticas. Materialidades, discursividades y culturas. Bogotá, Colombia: Instituto Caro y Cuervo, Imprenta patriótica, Bogotá. 2017. ISBN 978-958-775-992-1. Pp. -71-88-

Mann,Laura;Tung,Grace https://cultumatica.com/wp-content/ uploads/2017/10/Audiogu\%C3\%ADa-del-Museo-Metropolitano-NY-Una-nuevamirada-a-una-vieja-amiga.pdf(accedido: 5 de marzo de 2020)

Rosemberg, Marcela en https://cultumatica.com/tecnologia-audioguiasmuseos/(accedido: 5 de marzo de 2020) 


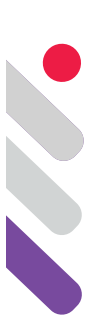

\section{Reflections about new perceptions on space and time: the use of mobile phone in the Metro de Santiago, Chile.}

\section{Introduction}

Before starting, I have tomake clear that the work I hereby share with you is distinctly preliminary in nature. It is still necessary to apply interviews, questionnaires and recordings of visual files, in order to triangulate and saturate these concepts, which are applied to Metro de Santiago passengers who focus their attention on their mobile phones.

In October 2018, the Undersecretary of Telecommunications with the Ministry of Transport and Telecommunications published the results of the First Radiography of Data Traffic carried out in Chile. Among the objectives of this study were: 1 ) Tomeasure the intensity of fixed broadband usage and mobile technologies, and 2) To anticipate the trends in the usage of information and communication technologies for Chile's social and productive development. Within the valuable results that were obtained, one figure especially caught my attention. The peak demand for mobile broadband is produced between 20 and $21 \mathrm{pm}$, that is to say, during the commuting back home of the largest part of the population; a very curious phenomenon. A space and time that was considered "dead" or just to waiting time, the idea of the movement as projection, today it is transformed by completely different, complex meanings. But, what has been the trigger of these changes in our perception of space and time?

To achieve a deep reflection we must focus on a determined, physical space. In this sense, Metro de Santiago represents one which offers a suitable stage. It represents a place of transit, that is, a non-place (Augé, 2012). Nonplaces are not only identified with empiric spaces, but also with spaces for communication. Passengers are in different places at the same time while using Metro. This indicates that "(...) the link between social relationship and context is becoming more and more problematic" (Augé, 2012: 155). This might stem 
from the effects of globalization and urbanization, which "(...) disconnect space and time" (Augé, 2012:159). The concept of a non-place provides us with the idea that Metro de Santiago is intertwined by other spaces of communication: subjects who text, read, listen to music, talk on the phone. It is precisely the interaction with the mobile phone that concerns us.

We have to think about this narrow relationship between subjects and mobile phones. According to estimations done by INE, in Chile the number of cellphones would reach 27 million. As we have seen, these are installed in our daily life in a way that is not only recurrent, but also implicit, as an extension of our minds and hands. It is common to observe Metro passengers engrossed in the activities they do on the little screens of their phones. To whoever contemplates this relationship, it might seem problematic, given that many times these passengers create obstacles for the mobility of other users. They walk and go upstairs with their sight set in this tool. Nevertheless, we forget that inside this device, there is an entire world. Everything indicates that this type of users keeps a fluid relationship with the mobile phone screen, producing such a level of harmony that many times a sense of time and space is lost (Case, 2014:45). The subjects are submerged into the device. It comes from there that in more than one occasion we witness little accidents, or even, that we ourselves are the protagonists of these issues.

\subsection{Observation in Metro de Santiago and User Typology by Floch}

It is at this point where I have to make a warning. The data that will be presented belong to an observation I did in 2016. I am aware that this might entail a limitation. However, my daily experience in Metro de Santiago, as both passenger and observer, makes me think that the trend noticed in 2016 is kept nowadays. In any case, I am countingon new opportunities to update these figures.

Now we can continue. During 2016 I carried out a participant observation of the passengers in Metro de Santiago, Chile, capturing their behaviors in the platforms and conducting structured interviews to the passengers. The observation was done during the first semester. Specifically, in the case of Hospital Sóterodel Rio station, from Monday to Friday, during morning time, between 8:00 and 9:00 am. This is when the largestportion of commuters journeys to the center of the city. As the station is located within Line 4, passengers travel mostly towards Tobalaba station. In the case of El Golf station, I also observed passengers from Monday to Friday, during the time after lunch, from 15:00 to $16: 00 \mathrm{pm}$. In this particular station, I wanted to avoid peak time, because during this period there is a predominance of workers who commute to the area and not passengers who reside there. 
Displacement of passengers was recorded and classified according to the User Typology of the Metro of Paris, as proposed by Jean Marie Floch (1993). For this author, a trip taken in Metro can be semiotically analyzed in the same way as a text, considering that it has a beginning (when we enter the station), a development (the displacement along hallways, stairs and platforms, and then the location inside the subway car), and an end (the arrival at the destination station and following exit) (Floch, 1993). Then, he provides us with a clearly identifiable rubric for the different moments that make up a journey through the underground network: "recognizable when making notes of the tracking -as we will see- through a determined sequence or macrosequence that is gestural (moving/motionless, standing/sitting, accelerated/slow pace) or proxemic (openness towards others/folding over oneself, distance/nearness, frontal or tangent encounter) (...)" (Floch, 1993:39).

The typology of users formulated by Floch comprises the following: Daydreamers, who focus their attention on one activity only, namely reading a book, checking their phones or listening to music. Presently, this would be the kind of user who is fixated on the screen of their mobile device. This category of user is self-absorbed, and they do not show great interaction with their surroundings. A common trait is that they do not make eye contact with the rest of the passengers who are waiting for the next train. Due to the fact that they are engrossed in their activities, Daydreamers generally stay in one determined point, keeping the same bodily position throughout their entire time on the platform. Then there are the Surveyors, who are noted for being spectators of the landscape offered by Metro. They know thestation in which they are, and therefore, they are aware of its spaces and the services being offered there, such as stores located inside the station. For this type of user a journey in Metro can be a pleasant walk, a spectacle to witness not only space, but also the other passengers. Then, we can also find the Pros, whose characteristic is their quick, swift movement. They appear to be busy, going towards some place in which they are being expected to arrive. As soon as they get to the platform they increase speed and try to dodge the flow of passengers. In general they know the platforms; they look for specific locations that will allow them to immediately get onto the next train. Or rather, they place themselves where they know they will be near the exit of the platform upon arrival. For this kind of passenger, Metro represents an aspect that is merely utilitarian: they do not execute other activities while they wait for the next train, and they do not interact in any way with the landscape. Finally, there are the so-called Strollers, who deploy their waiting time contemplating posters and information screens at Metro. Strollers appreciate unexpected spectacles happening in a space that contains such diverse people, and in such a quantity. That is to say, this category of passenger will stop to enjoy a musical show located at that station; they will stop to look 
at one of the many screens used to inform passengers about different topics of public interest and about the functioning of the Metro network during that time. This user also watches ad posters, meant to spread different cultural activities and money discounts for those who are part of Club Metro (a service to which all passengers can online subscribe to). In other posters information is offered to guide the journey of the passengers.

\subsection{Criterion for the Analysis}

Nowadays, Metro de Santiago comprises 139 stations, divided into seven lines which are mostly underground. In 2017 it was estimated that 685,1 million passengers used this means of transportation. Our criterion of observation was informed by studies on cognitive processing (Del Villar, 2006, 2014) stating that the differences about the amount of cognitive spaces simultaneously perceived would be determined by age differences. Because of this, three groups were established: age 16-18, age 20-35 and age 40-55. Each group consisted of 60 individuals ( 30 women and 30 men). Finally, two observation poles were established, namely two Metro stations (EI Golf and Hospital Sótero del Rio), in order to add the socioeconomic variable. In total, the platform displacement of 360 subjects was registered.

\subsection{Figures granted by the observation}

Now, these are figures offered by this participant observation:

\begin{tabular}{|l|l|l|l|l|l|l|}
\hline \multicolumn{7}{|c|}{ Comparative table by age of type of user } \\
\hline & $16-18$ & $20-35$ & $40-55$ & $16-18$ & $20-35$ & $40-55$ \\
\hline $\begin{array}{l}\text { Type of } \\
\text { User: }\end{array}$ & & & & & & \\
\hline Daydreamers & $\begin{array}{l}12,8 \% \\
(23)\end{array}$ & $15 \%(27)$ & $\begin{array}{l}13,3 \% \\
(24)\end{array}$ & $9,4(17)$ & $15 \%(27)$ & $8,3 \%(15)$ \\
\hline Surveyors & $1,7 \%(3)$ & $2,2 \%(4)$ & $6,7 \%(12)$ & $6,7 \%(12)$ & $1,1 \%(2)$ & $5 \%(9)$ \\
\hline Pros & $\begin{array}{l}16,7 \% \\
(30)\end{array}$ & $6,1 \%(11)$ & $7,2 \%(13)$ & $\begin{array}{l}14,4 \% \\
(26)\end{array}$ & $5,6 \%(10)$ & $7,8 \%(14)$ \\
\hline Strollers & $2,2 \%(4)$ & $10 \%(18)$ & $6,1 \%(11)$ & $2,8 \%(5)$ & $\begin{array}{l}11,7 \% \\
(21)\end{array}$ & $\begin{array}{l}12,2 \% \\
(22)\end{array}$ \\
\hline
\end{tabular}

Table $\mathrm{N}^{\circ} 1$ : Comparison by age of type of user 


\begin{tabular}{|l|l|l|}
\hline \multicolumn{3}{|c|}{ Comparison of types of users on the platforms by area: } \\
\hline Type of User: & El Golf & Hospital Sótero del Río \\
\hline Daydreamers & $41,1 \%$ & $32,7 \%$ \\
\hline Surveyors & $10,6 \%$ & $12,7 \%$ \\
\hline Pros & $29,9 \%$ & $27,8 \%$ \\
\hline Strollers & $18,4 \%$ & $26,8 \%$ \\
\hline Total\% & $100 \%$ & $100 \%$ \\
\hline
\end{tabular}

Table $N^{\circ} 2$ : Comparison of types of users on the platforms by area

Our attention will be focused on Daydreamers for two reasons. On the one hand, it is the number of passengers that predominates in the two observation poles which were selected for this register. At Hospital Sótero del Rio station a figure of 32, 7\% Daydreamers were registered, corresponding to 59 users from a total of 180 passengers. Surveyors constituted a 12, $8 \%$ (23 cases), Pros reached $27.8 \%$ (50 cases) and Strollers a 26, 7\% (48 cases). As for the passengers at $E I$ Golf station, Daydreamers registered a $41,1 \%$ (74 cases) out of 180 passengers who were observed. Surveyors reached $10,6 \%$ (19 cases), Pros a 30\% (54 cases) and Strollers a 18, 3\% (33 cases). The reason behind our focus on Daydreamers not only has to do with the majority they represent, but also it is related to the manner in which these subjects move within a space like Metro. We must recall that they are primarily self-absorbed in their mobile phones, without meaningful interaction with their surroundings. We believe that this way of not being present in the physical space, and on the contrary being focused on the screens of their devices, leads to consequences that are worth delving deep into in order to obtain better comprehension of new perceptions of space and time.

\section{The concept of "Cyborg": Origin and validity}

The reflection regarding the previously described observations led me to think about the relationship between Metro passengers with their smartphones. This narrow relation could be analyzed through the lens of Cyborg Anthropology.

But, where does the concept Cyborg come from? In academic context, it was coined for the first time by Manfred Clynes and Nathan Kline (1960) in a publication titled "Cyborgs and Space", framed in the preparations for sending the first human into the moon. Through this, a group of suggestions meant to shed light on what the equipment for space travelling should be is offered. 
Among its main ideas: 1 ) these devices should self-regulate, in a way that their benefits are enjoyed without the need for the subject to be aware of its use. This self-regulation would allow the extension of the organism's functioning in order to adapt to new environments. And 2) the most important aspect: Clynes and Kline thought about the idea of Cyborg as a way to liberate men and women so that they could explore, create, think and feel (Clynes\& Kline, 1960:27).

In February 1997, the magazine Wired published an article about Professor Donna Haraway, titled "You are a Cyborg". In that article, the author tells us that: "For Haraway, the realities of modern life happen in the midst of a relationship so intimate between people and technology that it is no longer possible to distinguish where we end and where the machine begins". And further on we can find a quote by Haraway where she asserts: "We are talking about new forms of subjectivity. We are talking seriously about world mutations that have never existed on the planet before. And they are not just ideas; we are talking about tangible realities". Haraway's claim disposes of the fantastical idea of the Cyborg as a Terminator or a Robocop, a man or woman with supernatural capacities and appearance. For decades technology has been thought of, and specially the Cyborg-esque, as having a spectacular character. This conception has made us lose sight that the range of this concept is much wider and more daily, to the point that Haraway dares to state that: "We are all cyborg". Amber Case (2014) revisits this idea: "As Haraway said, 'being a cyborg is not about how many pieces of silicone you have under your skin or how many prosthesis are in the body, it has to do with networks and information, and with the systems that compose our lives, and how these systems modify our own daily life without us realizing it".

The relationship I establish between Daydreamers' behavior and the concepts belonging to Cyborg Anthropology stems from my participant observation exercise while I make my own journeys through Metro, plus the literature I have accessed for these last two years. Nonetheless, I would like to clarify that I am fully aware that is an ongoing investigation (Flick, 2004; Angrosino, 2012). What I would like to make now is a conceptualization of daily situations that we all have witnessed and/or experienced in the context of Metro journeys. What scenarios do the Daydreamers live focused on the screens of their phones? And in what way these scenarios could transform our notions of space and time?

\subsection{Concepts from Cyborg Anthropology applied to the category "Daydreamer" by Floch}

Nervous System Extension: the predominant activities executed during a Metro journey consist of watching videos, playing videogames, texting (mainly using Whatsapp), scrolling down on Facebook or Instagram, checking e-mail, 
just to name a few of the most recurrent in my observations. This is not only a host of information, texts, images and sounds, but also emerging emotions, feelings and socialization dynamics. The concept of Extension of the Nervous System Extension points to the adoption of a tool that besides from extending our physical capacity also expands on our cognitive ability.

We know that the adaptation of tools is not something new in the history of humankind. Since the invention of the wheel, everything has been adapting new objects in order to better our life quality or to increase our abilities (Fairclough, 2010; quoted in: Case, 2014:43). The difference between the previous adaptation of other tools and the adoption of the smartphone is that never before the subjects were so exposed to the infinite possibilities of communication that this little screen provides to extend our capacities. The before mentioned activities that seem to routine to use, like checking Instagram, texting on Whatsapp, reading the news feed, watching a video, etc, they all imply an extension of ourselves. Never before a tool so small had allowed us to store such amount of information like files, photos, phone numbers and maps, next to the possibility of constantly modifying all this material. Just as an example, we can think of Instagram as a display cabinet, a curator of itself, even with the usage we give to emojis in our bios (Moreno Barrenche, 2019). The staging of Instagram is not just that, because with exposition comes the replies, other users' feedback, from other technology devices. In this way, the extension of our cognitive capacity increases, this time only shaped by static materials, but also susceptible to changes that emerge from others' replies. What I what to point out with this is: we are constantly modifying the way in which we represent ourselves through our mobile phone, in a virtual space (that is, not physical), as it is the case with Instagram, via the storing of photos and videos, and to that host of information we have to ass other users' replies. All of this gathers in our phones' screens.

-Flow: at the beginning of this presentation I talked about how subjects submerging in their mobile phones are prone to lose track of space and time (Case, 2014:45), and even to suffer accidents along their displacement. This is due to the sensation of Flow. The fixation on screens not only tells us about the Daydreamer's self-absorption, but also about the concentration when being immersed in the device, enabled by the way in which the device was designed. Let us think about mobile phones that did not have access to the internet, and that had a keyboard to type in numbers. Screens were not sensitive to fingerprints. Starting many years ago, the keyboard has disappeared and we are now facing a screen that is flat and ultrasensitive, with sharp colors that invite to interaction. From this design the gesture of scrolling is born. Attention is put onto the screen, onto what emerges at every moment, and the thumb is moving without us deciding what actions it makes. In this way, Daydreamers can lose 
track of space and time during their Metro journey, even while scrolling upstairs or along the platforms; or while they scroll on the trains, the loss of space and time notions is such that they do not get off at the station they should.

-Diminished Reality: it describes a process of information blocking, either real or digital, within reality itself (Case, 2014:39). In the context of Metro de Santiago, or any means of transportation, it is usual to find oneself surrounded by unknown people, and for the most part the way to handle this large amount of people consists of ignoring, or as this concept proposes, avoiding reality. The action of editing the space in which we are is not something new. However, in the case of Metro, and under the conditions that mobile phone interaction provides, the concept of Diminished Reality implies the productions of a space never seen before, with its own codes of communication and social dynamics. While using Metro, the Daydreamer not only modifies their reality, but also places him or herself in a completely different place. The consequences of this manner of perceiving space are not entirely notified and it becomes necessary to dig deep in them.

As it was said at the beginning of this presentation, a journey in Metro used to be considered waiting time, a paused period between the origin and destination of the passenger. Today, that time stopped being dedicated to waiting and it is completely crossed by multiple possibilities of communication thanks to the mobile phone. For instance, and always under the optics of Diminished Reality, the Daydreamer is located on train or on the platform and they text with a relative living in another country, they play video games, scrolls down on Instagram, just to mention a few examples. Is there a consequence to the disconnection with the immediate physical context? If the answer were positive, which would these consequences be?

A few weeks ago I listened to someone say: "When Metro is full (sic) my only way to escape is through the screen". This quote poses a question with regards to the mobile phone: are we allowed to expand on the notion of space (in a sense similar to the Nervous System Extension) or is it an effect of the reduction of space in the physical world (working as a substitute for the lack of physical space)?

\section{Preliminary considerations and future lines of investigation}

My reflection about Metro passengers and their relationship with mobile phones would not have been possible without the JM Floch's typology from 1993 and his semiotic reading of the Metro journey. Throughout the elaboration of this text I have considered the need to establish a typology for mobile phone users that is in agreement with Floch's proposal in the beginning of the 90s. In a preliminary way, I have observed three moments of this user/mobile phone interaction that might become into categories for analysis: 1 ) the subject stares 
at the screen without intervening in what happens in it (they check YouTube videos, plays videogames, etc), 2) the subject scrolls down without stopping any time (usually in social media), and 3 ) the subject interacts opening and closing windows and interfaces (for instance, they text with one or more people and they check their social media).

At the beginning of this presentation I quoted Marc Augé by referring to the places and non-places as a result of the ever more conflictive relationship between context and social relation, as an effect of globalization. And even though I am not losing awareness that my work still needs the triangulation of the data, everything indicates that this conflictive relationship also falls under the relationship of space and time. What consequences could this bring? I dare to suggest that the imbalance between space and time would lead to a fragmentation of social life never seen before. But I fear that delving deep into this idea, at the moment being, when I lack material for analysis would be imprudent and irresponsible.

I would also like to return to the moment when I quoted the creators of the concept Cyborg, Clynes \& Kline, who in 1960 elaborated a group of proposals so that the first person travelling to the moon couldadopt tools which in turn would boost their physical capacity in an environment which they were not familiar with. The original idea consisted in freeing humans so that they could explore. Then, in 1997, in the article published by Wired magazine, Donna Haraway affirms: "you are a cyborg", expanding on the concept and making it accessible to all. For Haraway, the cyborg is here and we must accept the invitation that technology poses in order to modify our capacities for our own benefit. The machinecan be a possibility to build not only new spaces and temporalities, but also to propose other identities and relationships. And this will only happen as long as we are conscious of the dynamics produced because of this relationship. Then, it is beneficial to ask, how are we living this possibility? What happens to what Clynes\& Kline were looking for? How is the possibility of liberation which was supposed to happen after the adaptation of technology to the service of mankind nowadays?

\section{Bibliography}

Journals:

DEL VILLAR, Rafael. 2006. Nuevas tecnologías y construcción de identidades. Revista DeSignis N5, Corpus Digital. Barcelona: Editorial Gedisa, 189-201.

DEL VILLAR, Rafael. 2014. Brecha Digital, Categorías Perceptivas y Cognitivas. Revista Comunicación y Medios $N^{\circ}$ 17. Santiago: Ediciones Instituto de la Comunicación e Imagen, Universidad de Chile, 87-101. 
MORENO, Sebastián. 2019. La proyección online del yo entre individuación y colectivización. Revista Inmediaciones de la Comunicación. Vol $14 N^{\circ} 1$. Montevideo: Universidad ORT Uruguay.

Books:

ANGROSINO, Michael. 2012. Etnografía y observación participante en Investigación Cualitativa. Madrid: Ediciones Morata.

AUGÉ, Marc. 2012. La vida en doble: etnología, viaje, escritura. Buenos Aires: Editorial Paidós.

CASE, Amber. 2014. An IlustratedDictionary of Cyborg Anthropology. Middletown, DE: CyborgAnthropology.

FLICK, Uwe. 2007. Introducción a la investigación cualitativa. Madrid: Ediciones Morata.

FLOCH, Jean-Marie. 1993. ¿Es usted agrimensor o sonámbulo? En Semiótica, marketing y comunicación. Barcelona: Editorial Paidós.

Internet Sources:

ASTROZA, Alonso \& Eduardo GRAELLS-GARRIDO. 2014. 2 S: Visualización de Dos Santiagos. http://dcc.uchile.cl/ egraells/abrecl/ (Fecha de acceso: 16 de agosto 2019)

BOCZKOWSKI, Pablo, Eugenia MITCHELSTEIN \& Mora MATASSI. 2018. Vivir en las redes. Publicado en Revista Anfibia. http://revistaanfibia.com/ensayo/vivir-enlas-redes/ (Fecha de acceso: 22 de agosto 2019)

CLYNES, Manfred\&Nathan KLINE. 1960. Cyborgs and Space. http://www. guicolandia.net/files/expansao/Cyborgs_Space.pdf (Fecha de acceso: 5 de agosto 2019)

Diario La Tercera, Pulso, "Metro de Santiago transportó 685,1 millones de pasajeros en 2017". https://www.latercera.com/pulso/noticia/metro-santiagotransporto-6851-millones-pasajeros-2017/184473/ (Fecha de acceso: 5 de diciembre 2018)

Diario La Tercera. "Celulares en Chile se acercan a los 27 millones". https:// www.latercera.com/entretencion/noticia/celulares-chile-se-acercan-los-27millones/63290/ (Fecha de acceso: 10 de diciembre 2018)

HARAWAY, Donna. 1984. Manifiesto Cyborg. https://xenero.webs.uvigo.es/ profesorado/beatriz_suarez/ciborg.pdf (Fecha de acceso: 20 de agosto 2019) 
Revista Wired. 1997. "You are cyborg". https://www.wired.com/1997/02/ ffharaway/ (Fecha de acceso: 16 de agosto 2019)

Subsecretaría de Telecomunicaciones, Ministerio de Transportes y Telecomunicaciones, Gobierno de Chile. 2018. Primera Radiografía de Tráfico de Datos. https://www.subtel.gob.cl/primera-radiografia-de-consumo-de-datosde-los-chilenos-revela-que-se-utilizan-principalmente-en-streaming-de-video/ (Fecha de acceso: 15 de agosto 2019) 
SEMIÓTICA DE LA/S MARCA/S 



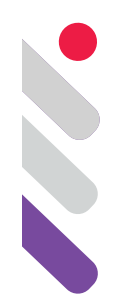

\section{Semiótica aplicada: campanha publicitária Journey, com Angelina Jolie, sob o espectro da teoria peirceana}

DOI: 10.24308/IASS-2019-5-015

Carolina Boari CARACIOLA

Escola de Comunicações e Artes da Universidade de São Paulo (ECA/USP), Brasil

carolboari@yahoo.com.br

\section{Considerações sobre o método de análise}

A análise da peça publicitária da campanha Journey, da marca de luxo Louis Vuitton, protagonizada pela atriz Angelina Jolie, partirá da fenomenologia, cuja função é "[...] apresentar as categorias formais e universais dos modos como os fenômenos são apreendidos pela mente" (SANTAELLA 2012: 07). Tais categorias são denominadas como primeiridade, secundidade e terceiridade.

A primeiridade relaciona-se ao acaso, é uma simples possibilidade, um ato contemplativo de imersão na qualidade e no sensível. Na primeiridade, há uma sugestão, ou evocação como possibilidade de funcionar como signo. Nesse momento de contemplação, as referências são abandonadas, procurando, apenas, apreender o modo como o fenômeno se apresenta. $O$ sentimento, na primeiridade, é vago, não havendo a mediação de outros signos. Os signos de primeiridade são denominados quali-signos, ou seja, o poder de sugestão de uma qualidade possibilita o funcionamento do signo.

A secundidade relaciona um fenômeno primeiro a um segundo, estando ligada às ideias de força bruta, ação e reação, conflito, resistência, esforço, aqui e agora. O estado contemplativo se esvai e o fenômeno se apresenta como realidade concreta, na sua natureza de sin-signo, um signo de existência, "[...] onde 'sin' quer dizer singular" (SANTAELLA 2012: 13). Secundidade começa quando um fenômeno primeiro é relacionado a um segundo fenômeno qualquer (CP 1.356-359). É a categoria da ação, do fato, da realidade e da experiência no tempo e no espaço: "Ela nos aparece em fatos tais como o outro, a relação, compulsão, efeito, dependência, independência, negação, ocorrência, realidade, resultado." (NÖTH 2003: 64) 
A terceiridade representa o efeito que o signo provocará em um possível interpretante. Os signos de terceiridade são denominados de legi-signos, em função de seu caráter de lei. Na terceiridade, os fenômenos são interpretados a partir de associações advindas de conhecimento prévio, as experiências colaterais. A terceira categoria corresponde à definição de signo genuíno, pois este é capaz de produzir outro signo, o que corresponde ao processo de semiose infinita; sendo assim, a terceiridade é um processo de crescimento contínuo. Terceiridade é a categoria que relaciona um fenômeno segundo a um terceiro (CP 1.377/ss): "É a categoria da mediação, do hábito, da memória, da continuidade, da síntese, da comunicação, da representação, da semiose e dos signos." (NÖTH 2003: 64)

Aanálise da peça publicitária terá início a partir do ponto de vista qualitativoicônico, detendo-se aos aspectos qualitativos da publicidade, tais como cores, linhas, texturas, formas, volume, movimento, aspectos presentificados em uma primeira apreensão, ou seja, referem-se "[...] à impressão que brota da primeira olhada". Esse primeiro nível de análise também desperta qualidades abstratas, bem como a previsão de "[...] associações por semelhança que essas qualidades estão aptas a produzir" (SANTAELLA 2012: 70). As relações de associações por semelhança são denominadas icônicas.

Em seguida, o ponto de vista singular-indicativo analisará o anúncio como algo existente em espaço e tempo determinados. As qualidades existentes serão examinadas de acordo com sua manipulação e uso.

Por último, o ponto de vista convencional-simbólico analisará o "poder representativo do produto", no caso em questão, da publicidade, o que ela simboliza, os valores culturais que Ihe foram transferidos, a imagem da marca e, de qual maneira a publicidade "[...] está contribuindo ou não para a construção ou solidificação da marca". (SANTAELLA 2012: 71)

As análises seguirão esses três pontos de vista mencionados anteriormente como guias de observação. Mas, inevitavelmente, em alguns momentos, os aspectos qualitativos-icônicos, singulares-indicativos e convencionaissimbólicos escorregam uns para os outros, pois secundidade pressupõe primeiridade e terceiridade pressupõe ambas. Isso significa que a análise será tanto mais justa quanto mais puder evidenciar esse processo que se assemelha a uma caixinha chinesa.

A imagem escolhida faz parte de um campo visual delimitado pelos contornos da fotografia, sendo que os elementos "[...] são visíveis até um ângulo limitado para a direita e esquerda e ainda mais limitado para cima e para baixo" (SANTAELLA 2005: 185-186). A fotografia da campanha utiliza o sistema ocidental de leitura, ou seja, da esquerda para a direita, na diagonal de cima para baixo, sendo que o nome da marca está colocado embaixo, na parte direita da imagem. A assinatura da campanha é o nome Louis Vuitton, escrito 
por extenso, sem o logotipo da grife. O nome da marca, bem como a legenda, que se diferenciam de acordo com cada anúncio, representam a parte verbal da publicidade.

O nome da marca, homônimo ao de seu fundador, é carregado de referências que se relacionam à tradição, ao luxo, à sofisticação e distinção, estando posicionado no canto inferior direito dos anúncios, gerando um efeito espelho em relação à celebridade. Dessa relação, pode-se concluir que a marca confere diferenciação a seus usuários, ocorrendo um processo de transferência de significado por similaridade. "O consumidor de repente 'enxerga' a similaridade entre a celebridade e o produto e está preparado para aceitar que os significados da celebridade estão no produto." (MCCRACKEN 2012: 122)

Nesse contexto, o nome da marca funciona como um signo genuíno, ou seja, um símbolo. Ele, "[...] além de sua função verbal [...] possui uma dimensão não-verbal, icônica, que incorpora, por conotação, significados complementares ao próprio nome." (PEREZ 2004: 53)

O nome da marca, escrito por extenso, lettering, é utilizado em letras maiúsculas, caixa alta, o que confere estabilidade, em função da manutenção de sua forma, sendo uma fonte sem serifas, similar à Futura, com legibilidade apropriada, em função de sua construção geométrica. As qualidades da tipografia que desenham o nome Louis Vuitton geram um efeito de sentido positivo ao serem transferidas à marca, corroborando seus valores de tradição, estabilidade, qualidade, elegância, sobriedade. A cor preta, utilizada no lettering, remete à tradição da marca e sua elegância. "[...] a renúncia às cores permite que o luxo se manifeste por si só [...] o preto é a mais nobre das cores." (HELLER 2013: 150)

Soma-se, a isso, o uso da cor branca, como fundo para o nome da marca, que na esfera emocional gera efeitos tais como sofisticação, moda, luxo, status, glamour. O branco remete à limpeza, sendo considerada a cor da verdade, do estilo minimalista, é imaculada. "O branco como cor proeminente, é usado também por reis e rainhas nas ocasiões mais importantes [...]." (HELLER 2013: 150)

A grafia da marca Louis Vuitton se assemelha, por similaridade, com a inscrição do nome de Luís XIV, o rei Sol, nos textos da época da monarquia, que se referiam ao rei como LOUIS LE GRAND "[...] era assim, em letras maiúsculas, que seu nome figurava frequentemente no meio de textos em caixa baixa." (BURKE 1994: 47)

Portanto, a referida campanha será analisada sob a perspectiva da semiótica peirceana, com o escopo de identificar quais são as características, os traços e os atributos específicos apresentados na publicidade da marca de luxo Louis Vuitton, campanha Journey, veiculada no ano de 2011, com a atriz Angelina Jolie. [...] as relações entre marketing, publicidade e semiótica estão a cada dia 
mais evidentes, tendo em conta a complexificação da nossa sociedade que cada vez mais consome símbolos construídos em grande parte pela publicidade do mundo capitalista. (PEREZ 2004: 142)

Sendo assim, a marca Louis Vuitton aqui funciona como signo, aliás um signo complexo, como são complexos quase todos os signos, uma vez que o objeto dinâmico é aquele que determina o signo e que este tem a função de representar todo o contexto histórico e evolução no tempo da marca Louis Vuitton, sendo então, o objeto dinâmico dessa marca. As campanhas e peças publicitárias são signos constitutivos da complexidade do signo maior que é a marca Louis Vuitton.

A marca Louis Vuitton apresenta como principal diferencial a tradição, possuindo uma história que, desde o princípio, esteve relacionada à realeza. A maison explora um posicionamento de superioridade no que tange à qualidade e sofisticação dos produtos que oferta, trabalhando com uma comunicação integrada, de modo a evidenciar seus principais atributos.

\section{Campanha Journey - Angelina Jolie, 2011}

A campanha publicitária Journey, da marca Louis Vuitton, foi também protagonizada, entre outros, pela atriz americana Angelina Jolie, veiculada no ano de 2011, produzida pela agência de publicidade Ogilvy \& Mather, de Paris, e fotografada por Annie Leibovitz, no Camboja.

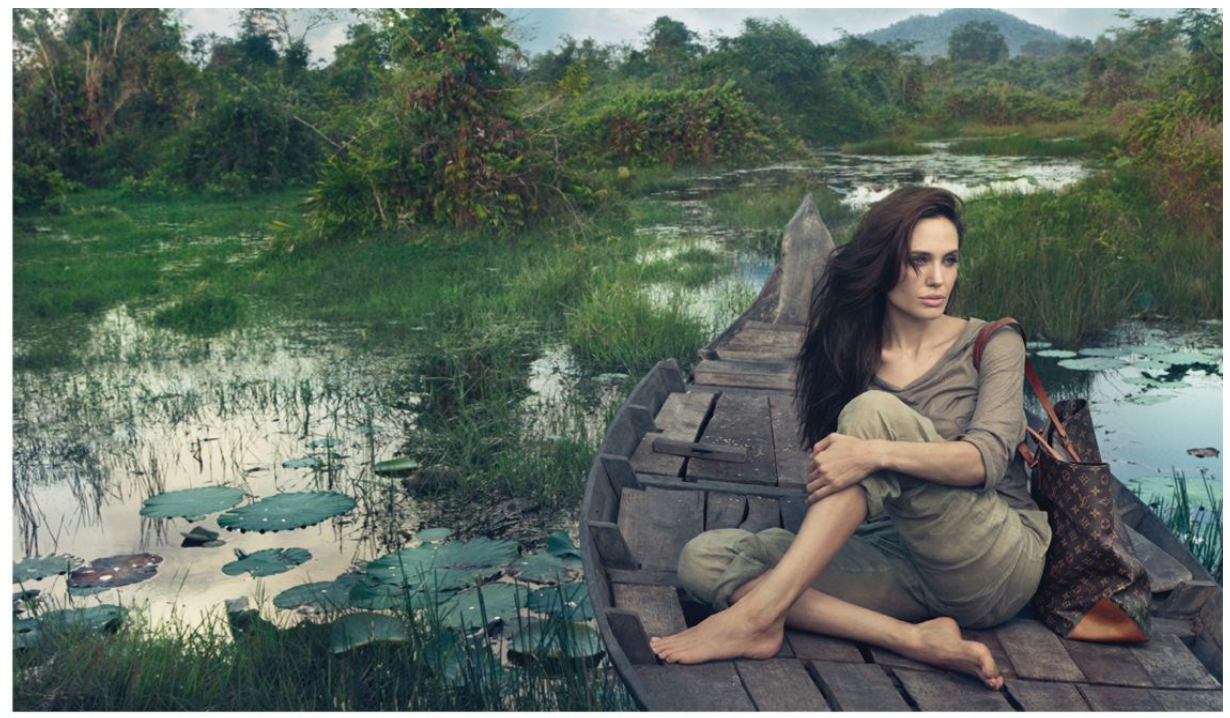

LOUIS VUITTON

Figura 1. Campanha Journey, Louis Vuitton, com Angelina Jolie (2011) 


\subsection{0 ponto de vista qualitativo - icônico}

O ponto de vista qualitativo-icônico nos induz à contemplação da imagem. "A leitura tem início pelos aspectos qualitativos, aqueles aspectos que falam aos sentidos, que produzem impressões relativas ao modo como algo se apresenta à percepção." (SANTAELLA 2010: 220)

Os signos, nesse nível, são denominados quali-signos, pois são vistos como pura qualidade. Quali-signos se referem à composição intrínseca do signo, sua aparência. Quali-signos são ícones na relação com seus objetos, isso porque representam o que podem representar tão só e apenas devido às qualidades que exibem, qualidades estas que podem apresentar correspondência com outras qualidades, quando passam a funcionar com signos. Já na relação dos quali-signos com seus interpretantes, eles são interpretados como remas, ou seja, hipóteses interpretativas. Por isso, quando interpretamos ícones, sempre usamos verbos como evocar, sugerir, parecer etc.

Portanto, nesse primeiro momento, o que se busca é perceber como as qualidades, tais como cores, formas, texturas, luminosidade, dimensão, entre outras, despertam sentimentos e associações.

A imagem do anúncio pode ser dividida em dois planos. No primeiro plano, posicionado ao lado direito, é possível vislumbrar a figura de uma mulher, descalça, sentada em um barco de madeira, usando roupas simples e casuais, sugerindo simplicidade e estranha familiaridade com o local no qual se encontra.

Elementos com diversas superfícies são apresentados, havendo predomínio da textura rústica, tanto da vegetação, quanto da madeira do barco, bem como das vestes da moça. As texturas podem ser entendidas como os "[...] aspectos da trama e do entrelaçamento das fibras que constituem a superfície [...]" (OLIVEIRA \& GARCEZ 2004: 53). A textura da madeira se mostra rústica, havendo uma ponta que direciona o olhar para o fundo da imagem, no qual é possível perceber uma possível montanha. No barco há algumas folhas pequenas, caídas atrás da modelo, o que sugere a troca de estação, em um clima ameno, em uma temperatura agradável.

A imagem apresenta o predomínio de linhas orgânicas, o que deixa a composição mais descontraída. A linha curva, formada pelo contorno do barco, conduz o olhar do espectador para cima, trazendo a sensação de movimento. A linha é uma marca contínua, sendo "[...] o sinal mais versátil, pois pode sugerir movimento e ritmo, comunicar sentimentos e sensações" (OLIVEIRA \& GARCEZ 2004: 50). Percebe-se o uso de uma disposição particular dos elementos no espaço visual para proporcionar enfoque ao tema e ao produto de modo sutil, conforme a análise que segue.

A imagem segue a regra dos três terços, cujo objetivo é capturar uma imagem visualmente equilibrada e agradável de se ver. A regra dos terços 
possibilita o melhor enquadramento da imagem, através de um exercício visual, no qual o fotógrafo, mentalmente, divide a imagem em três terços verticais e três terços horizontais, totalizando nove enquadramentos, conforme apresentado na figura abaixo. Desta forma, os elementos a serem mais destacados, ficarão posicionados nas intersecções entre as linhas, os denominados pontos de ouro. "Sendo assim, ao invés de centralizar o assunto, ele será posicionado nestes pontos, o que dará à foto uma composição mais elaborada. $O$ objetivo é conseguir uma maior harmonia entre os elementos da foto." ${ }^{11}$

Sendo assim, o rosto da mulher está posicionado próximo ao vértice superior direito do retângulo central, o que consiste em um ponto focal de destaque.

Partindo das considerações sobre composição visual feitas por Arnheim (2014), pode-se considerar a figura um triângulo deslocado do centro do espaço em primeiro plano. Essa forma geométrica é formada pelo barco, pela mulher e por sua bolsa. $\mathrm{O}$ cruzamento de suas pernas também forma a mesma figura geométrica.

É possível perceber, analisando a composição visual, que o barco, a mulher e a bolsa formam um triângulo deslocado do centro do espaço, no primeiro plano. Tal modo de distribuição dos elementos é característico do período renascentista, em que as figuras em primeiro plano eram dispostas de modo a formarem um triângulo no centro do espaço.

No anúncio em análise, a composição do primeiro plano está deslocada do centro, justamente para criar um efeito mais dinâmico, sugerindo mobilidade, o que serve para corroborar o tema das viagens. Embora o primeiro plano da imagem esteja deslocado, o fundo se mostra preenchido por vegetação, o que cria um equilíbrio simétrico na composição da foto. $O$ rosto da mulher está na linha do centro geométrico, o que favorece sua rápida identificação. A vegetação de fundo não está desfocada, proporcionando um equilíbrio simétrico no espaço.

A luz foi trabalhada conforme o uso convencional das pinturas renascentistas, utilizada de maneira frontal, ou vinda de cima, iluminando a imagem como um todo. A luz também possibilita o destaque da vegetação, contribuindo para uma visualização mais simétrica da imagem.

O anúncio parece estabelecer uma relação de associação por similaridade com a obra de arte renascentista Mona Lisa, de Leonardo da Vinci, o quadro mais famoso da história da arte. Analisando as duas imagens, percebe-se similaridade entre a constituição dos fundos, a vegetação, bem como a presença de uma montanha.

O fundo das duas imagens, a do anúncio e a da Mona Lisa, apresenta

${ }^{1}$ Disponível em: <http://www.infoescola.com/fotografia/regra-dos-tercos/>. Acesso em: 01 ago. 2019. 
características comuns; as vegetações presentes nos lados direitos são mais baixas que as do lado esquerdo, o que justifica o posicionamento da mulher e seu maior destaque. Porém, enquanto o cenário de Da Vinci é construído, o do anúncio é real e bastante significativo para a interpretação da campanha.

Ambas, Gioconda e a mulher que no anúncio se apresenta, aparecem com semblantes contemplativos, porém, enquanto a primeira olha diretamente para o receptor, a segunda desvia seu olhar, evocando mais introspecção. A mulher que, no anúncio publicitário, pode ser associada à Mona Lisa, personifica os requisitos de perfeição e beleza da contemporaneidade: alta, magra, jovem, olhos grandes e de pele clara, um resquício de beleza nobre (TUNGATE 2013).

As cores da imagem foram trabalhadas de maneira intensa. O fundo, composto pela vegetação, apresenta diversos tons esverdeados e azulados, enquanto os tons do barco e das roupas são terrosos, funcionando como tons neutros para não ganharem mais destaque do que a bolsa, cuja cor marrom mais forte se destaca na composição cromática. Dessa forma, a cor cria um ponto focal diferenciado para a mercadoria, funcionando também como um índice na relação com a bolsa que a atriz carrega em seu ombro, sendo possível reconhecer as siglas LV, em função das cores mais chamativas do material, marrom escuro e bege.

As cores apresentadas na imagem revelam um contraste entre suas temperaturas. Enquanto os tons esverdeados e azulados são frios, os tons terrosos transmitem uma sensação de temperatura mais quente, havendo uma reação mais dinâmica ao observá-los. "Estamos descrevendo uma qualidade que emana no objeto bem como nossa reação a essa qualidade." (ARNHEIM 2014: 360)

A mulher está olhando para o infinito, com semblante sereno, aparentemente sem maquiagem, o que sugere naturalidade, sensação aumentada pela presença da vegetação ao seu redor. Os cabelos mostram-se levemente ondulados, o que sugere movimento. $\mathrm{O}$ olhar da modelo não foca a câmera, ou seja, não dialoga com o receptor da mensagem, o que sugere ensimesmamento. A moça está sentada e seus pés estão dispostos em sentidos contrários. A mão esquerda está sob o joelho esquerdo e a mão direita não aparece, sugerindo que essa mão está servindo de apoio ao resto do corpo. A modelo se mostra confortável e adaptada ao local no qual está inserida.

O primeiro plano da imagem, ao lado esquerdo, bem como todo o segundo plano são compostos por vegetação com tons verdes e azulados que, em alguns pontos específicos, se torna mais aberta, possibilitando a visualização da água na qual o barco flutua. A água transmite a ideia de movimento e leveza, em um ritmo bastante lento e calmo.

A profundidade do espaço visual é enfatizada através da linha curva do barco, que aponta para o fundo da composição. Em alguns pontos, a vegetação 
é mais densa e alta, formando um cenário natural que vai direcionando o olhar para a montanha ao fundo da imagem.

Em suma, a composição da imagem sugere quietude, contemplação, serenidade, intimismo, introspeç̧ão, naturalidade, simplicidade, desprendimento. Vejamos, a seguir como esses aspectos encontram complementação nos outros dois aspectos do signo sob análise.

\subsection{0 ponto de vista singular - indicativo}

Sob o ponto de vista singular-indicativo a imagem é analisada no seu estatuto de existente singular. Essa imagem que se apresenta diante de nós, suas referências ao contexto no qual está inserida e as funções que desempenha.

O objeto em análise é também um anúncio publicitário da campanha Journey, da Louis Vuitton. A linguagem do anúncio é fotográfica, como é comum acontecer em imagens publicitárias, o que faz com que elas se constituam em legi-signos, pois corporificam um padrão que as tornam reconhecíveis como anúncios. Mas, em cada foto particular sempre domina o aspecto indicial, pela conexão dinâmica entre o objeto e a tomada que são constitutivos do signo fotográfico.

Nesse segundo momento, é fácil constatar que a mulher fotografada é Angelina Jolie, e que os elementos fotografados, tais como o barco, a vegetação, a montanha, a atriz, a bolsa e todos os demais itens existem na realidade, lá estavam fora da captura da tomada da foto. É a concretude de tais componentes que fundamenta os índices. Sendo assim, para que a imagem da atriz, por exemplo, esteja presente no anúncio, houve uma óbvia conexão entre Angelina e a fotografia. $\mathrm{O}$ anúncio, bem como os elementos nele presentes, conecta-se aos objetos existentes, fazendo que esse signo gere um interpretante dicente, ou seja, um signo de existência concreta.

O anúncio apresenta uma antítese visual em sua sustentação, o que causa, em um primeiro momento, um estranhamento. Angelina Jolie, ícone de glamour feminino, destaque em revistas por sua beleza e presença em eventos, sempre elegante e bem vestida, aparece, na publicidade, de maneira natural, simples, desprovida de uma grande produção, gerando um conflito entre a imagem captada e aquelas que são veiculadas pela grande mídia. Para decifrar esse estranhamento, é necessário recorrer ao objeto dinâmico da foto, aquilo que essa foto apresenta, indica e representa.

Angelina é a celebridade mais nova de todas as que participaram da campanha Journey, possuindo forte apelo de massa, em função dos filmes nos quais atuou em Hollywood, como Tomb Raider, no qual deu vida à personagem de videogame, Lara Croft, o que justifica a escolha de uma bolsa em seu anúncio, acessório considerado um produto de introdução ao universo do luxo. A bolsa é um artigo fundamental para uma mulher, pois conta sua história, carrega seus 
objetos pessoais, sendo o índice que a identifica mais imediatamente, revelando sua identidade através da marca, das cores, da textura, do modo de usar. "Não importa. Hoje em dia, mais do que qualquer outra coisa, a bolsa conta a história da mulher: sua realidade, seus sonhos. E, graças ao marketing das marcas de luxo, essa bolsa muda depois de alguns meses, como as estações, como seu estado de espírito." (THOMAS 2008: 151)

O produto em questão é de uso particular de Angelina, e está descontinuado, ou seja, não disponível para a venda, o que revela o objetivo de vincular a imagem da marca aos conceitos de altruísmo, benevolência, causas sociais, e não somente a vendas. Assim como a bolsa, as vestes da atriz são de uso pessoal, transmitindo a ideia de legitimidade na escolha da modelo, representando um endosso explícito que objetiva transferir os atributos de Angelina, tais como beleza, sofisticação e engajamento, ao produto.

Contudo, a biografia de Angelina é clara ao relatar que ela nem sempre foi considerada um ideal de comportamento. $\mathrm{O}$ início de sua carreira foi marcado por episódios de automutilação, internações por problemas mentais, uso de drogas, sendo considerada uma celebridade descontrolada. "[...] quando ainda estava na adolescência, Angelina foi rotulada de psicopata." (HALPERIN 2012: 43). Dessa forma, será que a escolha de Angelina como representante da Louis Vuitton poderia prejudicar a marca? A resposta vai justamente em direção contrária.

A carreira de Jolie foi se consolidando, ela ganhou uma série de prêmios, incluindo o Oscar de melhor atriz coadjuvante por Garota Interrompida, no ano 2000. No mesmo ano, Angelina começou a gravar Tomb Raider, no Camboja, sendo impactada pelo sofrimento humano do local, fato que modificou sua visão de mundo. "Ao retornar a Hollywood, achou difícil olhar para a sua vida da mesma maneira, novamente. Agora, ela havia, como mais tarde declarou, 'encontrado um propósito'." (HALPERIN 2012: 219)

A imagem maculada de Jolie foi se desfazendo a partir do momento em que se tornou uma celebridade engajada em causas sociais. "[...] associar um ator ou atriz a uma causa humanitária é um dos métodos mais efetivos de reparar ou transformar uma imagem manchada." (HALPERIN 2012: 238). No ano de 2001, Angelina recebeu o título de Embaixadora da Boa Vontade das Nações Unidas, ação que foi vista, a princípio, como mera estratégia de promoção de sua carreira, percepção revista em função da dedicação da atriz a causas humanitárias.

As Nações Unidas, até então, somente escolhiam celebridades de reputação inabalada para o posto de embaixadora, porém, com o objetivo de atrair um público mais jovem, nomeou Angelina para o cargo. A atriz passou a dedicar tempo e dinheiro a causas humanitárias. Visitou lugares como Paquistão, Bósnia, Iraque, Jordânia, e África a fim de direcionar sua fama para 
a questão dos necessitados. Em novembro de 2001, Angelina adotou um órfão no Camboja, rebatizando-o de Maddox Chivan, alterando definitivamente sua imagem, de polêmica e rebelde para uma mãe zelosa e solidária.

A fotografia de Angelina Jolie para a campanha Journey foi feita no Camboja, país pobre localizado no Sudeste Asiático, carregado de significados expressivos para a atriz, justificando a legenda "Uma única viagem pode mudar o curso de uma vida".

A propaganda com Angelina foi bastante criticada em função de especulações sobre o apagamento de 10 milhões de dólares para a atriz, sendo que uma parte desse valor seria destinado para as ações humanitárias das quais participa. Tal hipótese não foi confirmada por nenhuma das partes envolvidas,

A posição na qual Angelina se encontra na campanha não permite que suas tatuagens sejam vistas, ou seja, suas marcas do passado são ocultadas.

O cenário simples, porém significativo para a atriz, serve como moldura para Angelina aparecer deslumbrante, sem máscaras, sendo possível entender que a verdadeira beleza está na atitude, na autoconfiança, e que tais qualidades são intrínsecas a quem possui uma bolsa Louis Vuitton. $\mathrm{O}$ destaque das cores marrom e bege corrobora tal pensamento, uma vez que essas cores evocam a identidade da marca Louis Vuitton, funcionando como fortes traços de identificação.

A parte verbal do anúncio é composta pela inscrição do nome da marca, Louis Vuitton, e pela legenda: "Uma única viagem pode mudar o curso de uma vida". Através de uma associação por contiguidade, o anúncio tenta associar o produto, no caso, a bolsa, a uma transformação decorrente de uma viagem que transformou a vida de Angelina e modificou sua imagem. "[...] Nas imagens, a sugestão, presente na transmissão de valores associados a certos objetos, torna necessário que eles sejam mostrados lado a lado do produto." (SANTAELLA e NÖTH 2010: 134). Tais afirmações, para serem interpretadas corretamente, requerem um conhecimento prévio, uma experiência colateral com o objeto dinâmico, a mulher real, para nós, em suas aparições evidentemente também sígnicas, do signo complexo Angelina Jolie, como foi visto anteriormente.

\subsection{0 ponto de vista convencional - simbólico}

A campanha Journey, da Louis Vuitton, é um meio privilegiado para se transmitir e persuadir os valores simbólicos contidos na marca, argumentando, de forma direta ou indireta, seus objetivos.

A veiculação de uma propaganda deve apresentar alguns objetivos, tais como, aponta Perez (2004): ser informativa, persuasiva, memorizada e agregar valor à mercadoria. Informar sobre a existência do produto é essencial para que o consumidor o conheça e, posteriormente, se interesse. No que tange à persuasão, a publicidade tem como objetivo influenciar o consumidor, 
levando-o à ação de compra. A função de lembrança busca trazer para a mente do consumidor uma rede associativa de significantes que fogem da mente consciente.

As bolsas, no segmento de luxo, são produtos fáceis de serem vendidos, não demandam prova, possibilitam um primeiro contato com o setor, sendo lucrativos para a própria empresa, pois o preço de venda é bem maior do que o custo de fabricação. A Louis Vuitton, por exemplo, obtém um lucro de até treze vezes em relação aos gastos com produção do produto. (THOMAS 2008: 152)

Os referidos acessórios se tornaram produtos propulsores das marcas de luxo e se renovam com grande rapidez por meio das its bags, bolsas da moda cobiçadas pelo público alvo. Conforme explica Thomas (2008: 152), "'it bags': os modelos de bolsa mais recentes e badalados que - graças às campanhas publicitárias das marcas de luxo e artigos em revistas de moda - se tornam o artigo da estação que ninguém pode deixar de ter."

De acordo com a citação, percebe-se que possuir determinada bolsa é uma obrigação para quem deseja ser reconhecido como conhecedor de moda e pertencer a um grupo aspiracional. A publicidade das marcas de luxo, por esse motivo, explora a imagem das bolsas com o objetivo de intensificar suas vendas através da obsolescência dos modelos.

Nesse anúncio, Angelina aparece com estilo natural, aparentemente sem maquiagem, fato que encontra congruência na nova tendência de beleza, que incentiva um visual natural. Nesse sentido, percebe-se uma volta ao pensamento clássico, que define que a beleza coincide com a verdade, "[...] porque, de certo modo, era a verdade que produzia Beleza." (ECCO 2010: 317). Justifica-se, assim, a similaridade que encontramos entre a composição desse anúncio e as pinturas clássicas renascentistas.

A suposta antítese provocada pela simplicidade da modelo e o status que produtos de luxo conferem a seus usuários, é derrubada a partir das constatações de que os consumidores desse segmento não se identificam mais com o uso de imagens que contenham ostentação e mero glamour. De acordo com um estudo global realizado pela agência McCann, "A verdade sobre a riqueza", foram identificados novos padrões de comportamento do público de alto poder aquisitivo. A pesquisa apontou que: "[...] o retrato de pessoas ricas envolvidas em atividades glamorosas e marcadas pela ostentação estão fora de moda. Hoje, o arquétipo masculino de riqueza não é mais o do homem maduro navegando em seu iate, tendo ao seu lado um troféu em forma de beldade com olhar blasé." ${ }^{2}$

Na realidade, a moda alicerçada na negação de artifícios embelezadores é construída através do uso de produtos cosméticos que simulam o efeito natural, o que determina uma realidade simulada. O luxo, por sua essência,

${ }^{2}$ Material disponibilizado pela agência. 
não é simples nem natural, porém, mostra-se cada vez mais desvinculado de aspectos meramente ostentatórios.

O anúncio, dessa forma, acompanha a nova tendência do luxo, que se baseia na busca de autossatisfação. O consumidor de luxo, muito mais do que exibir as marcas que usa, busca uma recompensa, um prazer intimista que não precisa ser sinalizado por meio de logotipos.

A Louis Vuitton, acreditando nessa tendência, exibiu, no desfile da coleção outono/inverno 2013, produtos com logotipos reduzidos e, até mesmo, sem o monograma LV. Pesquisa realizada pelo instituto Ipsos apontou que "quanto maior o logo, mais acessível é o preço da bolsa." ${ }^{3}$ Outro estudo, realizado pela empresa Bain\&Company, comprovou que há um público emergente, sobretudo em cidades como Pequim e Xangai, que prefere produtos de luxo mais discretos. O continente asiático, com exceção do Japão, responde por $28 \%$ das vendas da Louis Vuitton, o que justifica a preocupação com as preferências desse público. A mudança de logotipos proeminentes para mais discretos revela uma mudança no comportamento de uma parcela de consumidores de luxo que, em vez de ostentar, prefere ter um entendimento maior do mercado, obtendo uma experiência pessoal diferenciada. ${ }^{4}$

Sendo assim, cabe a Vuitton, e às demais marcas de luxo, encontrar um equilíbrio entre exclusividade e popularidade de seus produtos e inscrição de logotipos.

\section{Considerações finais}

A presente análise semiótica do anúncio com a atriz americana Angelina Jolie, a mais nova de todas as celebridades que participaram da campanha Journey, até o momento, evidencia um enfoque em um público mais novo, o que justifica a presença da bolsa, elemento de introdução no segmento de luxo. Angelina é fotografada com um visual simples, em um cenário natural e representativo para a mesma. $O$ foco desse anúncio é o entrelaçamento da marca com causas sociais, utilizando o endosso de Jolie para corroborar tal estratégia.

A análise do anúncio, que incorpora a campanha Journey, possibilita a visão de uma transformação na comunicação da marca Louis Vuittion. A primeira mudança significativa refere-se ao fato do tema - jornadas - ser o principal conceito a ser trabalhado, colocando a mercadoria como um acessório da narrativa. O anúncio analisado expressa uma tendência mais natural, benevolente, aproximando o conceito de luxo ao de altruísmo, contudo, em

\footnotetext{
${ }_{3}^{3}$ Disponível em: <http://wap.noticias.uol.com.br/midiaglobal/lemonde/2010/06/22/a-formulamagica-da-industria-do-luxo-logotipo-pequeno-produto-caro.htm>. Acesso em: 22 ago. 2019. ${ }^{4}$ Disponível em: <http://www.businessoffashion.com/2013/03/has-logo-fatigue-reached-atipping-point.html>. Acesso em: 22 ago. 2019.
} 
toda campanha, a marca Louis Vuitton é apresentada como sinônimo de luxo, elegância e sofisticação, independente do momento ou do contexto em que esteja inserida, tão universal quanto são os mais relevantes valores humanos. Essa é a estratégia.

\section{Referências}

ARNHEIM, Rudolf. 2014. Arte e percepção visual: uma psicologia da visão criadora: nova versão. Trad. Ivonne Terezinha de Faria. São Paulo: Cengage Learning.

BURKE, Peter. 1994. A Fabricação do rei. A construção da imagem pública de Luís XIV. Trad. Maria Luiza X. de A. Borges. Rio de Janeiro: Jorge Zahar Editor.

ECCO, Umberto. 2010. História da beleza. Trad. Eliana Aguiar. Rio de Janeiro: Record.

HALPERIN, Ian. 2012. Angelina \& Brad: a incrível história que não foi contada sobre Brad Pitt e Angelina Jolie, o casal "Brangelina". Trad. Mariana de Carvalho Mesquita Santana. São Paulo: Jardim dos Livros.

HELLER, Eva. 2013. A psicologia das cores: como as cores afetam a emoção e a razão. Trad. Maria Lúcia Lopes da Silva. São Paulo: Gustavo Gili.

MCCRACKEN, Grant 2012. Cultura \& consumo II: mercados, significados e gerenciamento de marcas. Trad. Ana Carolina Balthazar. Rio de Janeiro: MAUAD.

NÖTH, Winfried. 2003 Panorama da semiótica: de Platão a Peirce. São Paulo: Annablume.

OLIVEIRA, Jô; GARCEZ, Lucília. 2004. Explicando a arte: uma iniciação para entender e apreciar as artes visuais. Rio de Janeiro: Ediouro.

PEIRCE, Charles Sanders. 1974. Escritos coligidos. Seleção de Armando Moura D'Oliveira. Trad. Armando Moura D'Oliveira e Sergio Pomerangblum. São Paulo: Abril Cultural.

PEREZ, Clotilde. 2004. Signos da marca: expressividade e sensorialidade. São Paulo: Pioneira Thomson Learning.

SANTAELLA, Lucia. 2012. Semiótica aplicada. São Paulo: Pioneira Thomson Learning.

SANTAELLA, Lucia. 2005 Matrizes da linguagem e pensamento: sonora, visual, verbal: aplicações na hipermídia. São Paulo: lluminuras. 
THOMAS, Dana. 2008. Deluxe: como o luxo perdeu o brilho. Trad. Ana Gibson. Rio de Janeiro: Elsevier.

TUNGATE, Mark. 2013. O império da beleza: como o marketing da L'Oreal, Natura, Avon, Revlon, Nívea e outras mudou nossa aparência. São Paulo: Seoman. 


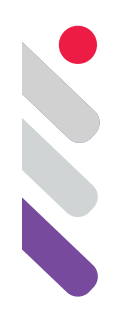

\title{
Modalidades de inserción de emergentes culturales en la comunicación de las marcas
}

DOI: 10.24308/IASS-2019-5-016

\author{
Claudio Centocchi \\ Universidad de Buenos Aires, Argentina \\ cfcentocchi@yahoo.com
}

\section{Planteamiento general}

Existen numerosas definiciones de lo que es la marca, un fenómeno actualmente tan complejo que se torna muy dificultoso el intento de conceptualizarla de manera abarcativa. Desde variadas disciplinas se ofrecen aproximaciones más o menos precisas, que pueden ordenarse según cuáles son las respuestas a lo qué es la marca y quiénes la generan. Lugares necesarios por los que debe atravesar al principio esta cuestión.

Así, por una parte, se distinguen los enfoques que entienden a la marca como un ente concreto, observable, de aquellos que la conciben como un proceso, una forma vacía, un dispositivo de gestión de la discursividad social. Frente a expresiones que la caracterizan usualmente como un nombre, un signo, un diseño, una combinatoria de elementos perceptibles cuyo fin es identificar un producto y diferenciarlo de sus competidores (Kotler 1990; Costa 2004), se alzan al calor de la posmodernidad las afirmaciones acerca de que la marca es "un motor semiótico" (Semprini [1992] 1995: 47), "una máquina productora de significados" (Semprini 1995: 50), "un proyecto de sentido" (Semprini 2006: 209) $)^{1}$.

Y respecto a la autoría, que se entrecruza con las posiciones anteriores, se hallan los defensores que enfatizan que la marca es obra del anunciante y la agencia (intentio auctoris) (Séguéla 1984), que se oponen a los que sostienen que finalmente es el resultado de las interpretaciones y conductas de los consumidores (intentio lectoris) (Batey [2008] 2013). Extremos que se buscan

\footnotetext{
${ }^{1}$ Esta contraposición surge cuando se confunde una marca específica ("marca-dato resultante") con la marca como un ente teórico y abstracto. Ver Semprini (1995: 48).
} 
conciliar por vía conceptual a través del par "identidad" e "imagen" (Chaves 1988); o bien superar a partir de considerar a la marca una dimensión colectiva, compartida y pública que procede de la convergencia de los discursos suscitados sobre ella por múltiples actores, desde ambos polos teóricos de la comunicación (Semprini 1995).

Este artículo se inscribe en la vertiente que privilegia las facetas procesual e intersubjetiva de la marca. El interés principal consiste en reflexionar acerca de cómo funciona ese motor, el cual se dedica a procesar diferentes áreas de la producción cultural global: modos de comportamiento, rituales sociales, tendencias ideológicas, pautas estilísticas. Un accionar, cuyo output es un "bricolaje", que suele diseminarse de parte de las marcas comerciales a través de textos publicitarios que procuran alentar en los casos más corrientes la compra de un producto/ servicio.

La publicidad se destaca como un espacio notable de interrelación discursiva, donde las marcas no operan de forma homogénea al momento de recoger y conceptualizar cada aspecto de lo que se entiende como realidad. La metáfora del motor ubica a la marca como la instancia enunciativa que imaginariamente maneja la intertextualidad, esa condición inherente de cualquier discurso que en el campo publicitario se manifiesta particularmente ostensible con el fin de lograr un vínculo cómplice con el destinatario. La estrategia recurrente para tratar de dominar la progresiva inestabilidad, infidelidad, que se registra hoy en las prácticas de consumo.

Desde hace cuatro décadas se observan transformaciones significativas que se conectan con el surgimiento y expansión de la modalidad estilística denominada "posmoderna" (Krief 1984) o "pospublicidad" (Adam \& Bonhomme 1997). Las marcas que expresan ese aún difuso modo de hacer publicitario se muestran innovadoras ante las que continúan respetando las reglas tradicionales de la modalidad "clásica" o "moderna".

Sin negar la incidencia de otros niveles que organizan el sentido (medio, dispositivo, tipo de discurso, género), el estilo -condensado aquí en el antagonismo macro "clásico" versus "posmoderno"- determina con fuerza la constante actividad semantizadora de la marca; interviene en definitiva en cómo esta se presenta -atractiva, con distintas personalidades- en sus historias.

Aunque a menudo la publicidad sea juzgada como fantasiosa, la enunciación marcaria demuestra a través de esa apropiación y re-trabajo sobre los más diversos aspectos que componen la cultura que nunca desatiende las inquietudes sociales. Qué clase de cuestiones recorta y cuáles son las posiciones que suele adoptar el enunciador/ marca, según la modalidad estilística que se actualiza, es lo que se intentará describir a continuación. 


\section{La publicidad de marca clásica}

La publicidad que se centra en resaltar atributos de la marca -y no del producto ${ }^{2}$ - surge recién a fines de los años ' 40 del siglo $\mathrm{XX}$, cuando cobra aceptación entre los publicitarios la idea de que la marca pudiera contar con una identidad elaborada, que no se limitara a una mera asociación con una mascota o una imagen impresa en una etiqueta (Klein 2000).

Este posible ha permitido renovar un arsenal de argumentos desgastados por la creciente estandarización de los productos. Les otorga una mayor libertad a los creativos para proporcionarle al objeto publicitado cualidades maravillosas, extrañas al genérico, al asociarlo a través de procesos metonímicos y/o metafóricos a un contexto deseable para el destinatario (Tassara 2002).

La persuasión se apoya aquí fuertemente en el registro visual: se privilegian las operaciones icónicas (Peirce [1895 1902] 1978; Verón 1987) en función de ofrecer una representación familiar de lo real que origine la esperada identificación del consumidor potencial. Aunque se caiga con recurrencia en una exagerada euforia y se muestre un mundo "demasiado publicitario", que las racionalizaciones inmediatas cuestionan sin detenerse a meditar el porqué de su larga vigencia.

Bajo esta modalidad estilística, la marca suele brindar historias en las que indica la solución a problemas o carencias puntuales; promete un diferencial intangible, un beneficio atractivo de carácter emocional para el propio destinatario, extensible muchas veces a su entorno más próximo. Estos discursos resaltan la apoteosis (happy end) que se obtiene gracias a la intervención heroica del producto/ marca, que conlleva la eliminación del desequilibrio inicial.

De tal modo, la marca pretende ser seductora, informativa y seria dentro de ese marco algo fantasioso, poblado de seres que despiertan admiración por haber logrado finalmente satisfacer sus más diversos anhelos. Plenitud que uno solo puede alcanzar a partir del uso/ consumo del producto/ marca, según las propuestas comunicacionales de tinte egoísta que difunden innumerables "motores semióticos" (Semprini 1995: 47), sin afán de ocultar sus propósitos lucrativos.

Apelándose pues a este tipo de estrategias, Coca Cola se afirma como garante de la felicidad familiar, mientras Fanta es la que acompaña y da energía a los adolescentes en la búsqueda de aquello que les apasiona.

\section{La publicidad posmoderna o pospublicidad}

A la variante descrita en el punto anterior, se le ha sumado desde los años '80 otra modalidad, de la mano de la "publicidad oblicua" (Floch 1990)

\footnotetext{
${ }^{2}$ No se abordará la denominada "publicidad de producto", la variante estilística publicitaria más antigua, por la circunscripción temática que se ha efectuado. Para más detalles sobre la misma, consultar Tassara (2002).
} 
y el impulso provocador del fotógrafo Oliviero Toscani para la firma italiana Benetton. La variante posmoderna procura comunicar también atributos marcarios, pero mediante la utilización de procedimientos distintos de aquellos que caracterizan a la publicidad tradicional.

La persuasión del enunciador publicitario posmoderno se basa en exponer un discurso espectacular, llamativo, ingenioso, divertido, irónico, a veces sin una referencia directa acerca del producto/ marca más que su mera nominación (Krief 1984; Tassara 2002). Busca distinguirse en virtud de los modos de decir (plano de la enunciación) y no ya por lo qué dice (plano del enunciado); detrás opera la creencia que "quien emite bien, produce bien" (Krief 1984: 238): si la marca se destaca en su acción comunicacional, se supone que la mercancía que avala resulta óptima para el consumidor por más que no lo indique expresamente $($ gran $\operatorname{marca}=$ gran jugada $=$ gran producto) $($ Krief 1984):

La modalidad posmoderna sobresale por objetar de manera ligera su adscripción architextual (Genette 1982) al proponerse como un mensaje (anti)publicitario que empero no abandona su meta comercial (lo que hace es encubrirla). En este sentido, se aparta de las situaciones eufóricas, como de otras convenciones identificatorias de la publicidad clásica, por medio de la mofa, o bien pretendiendo exhibir el mundo "real" sin filtros "deformantes".

Esta última vía implica una retórica de la transparencia que comprende el predominio de operaciones referenciales, litóticas, indiciales en los registros verbal y visual (Peirce 1978; Verón 1987). A nivel temático, el enunciador/marca suele centrarse en problemáticas sociales que atañen al individuo en calidad de ciudadano (derechos civiles, políticos, humanos); se muestra preocupado por un grupo de seres vivos que se halla postergado por las entidades públicas. Intereses que no siempre se conectan directamente con el producto/ servicio que la marca sostiene.

Desde las polémicas campañas de Benetton -que aludían a la mafia, el SIDA, la guerra (figura 1)-, este tipo de comunicación publicitaria que se presenta como altruista se ha multiplicado y diversificado (figura 2). Ya no se contenta exclusivamente con denunciar la desgracia, lo funesto con impactantes testimonios fotográficos. 

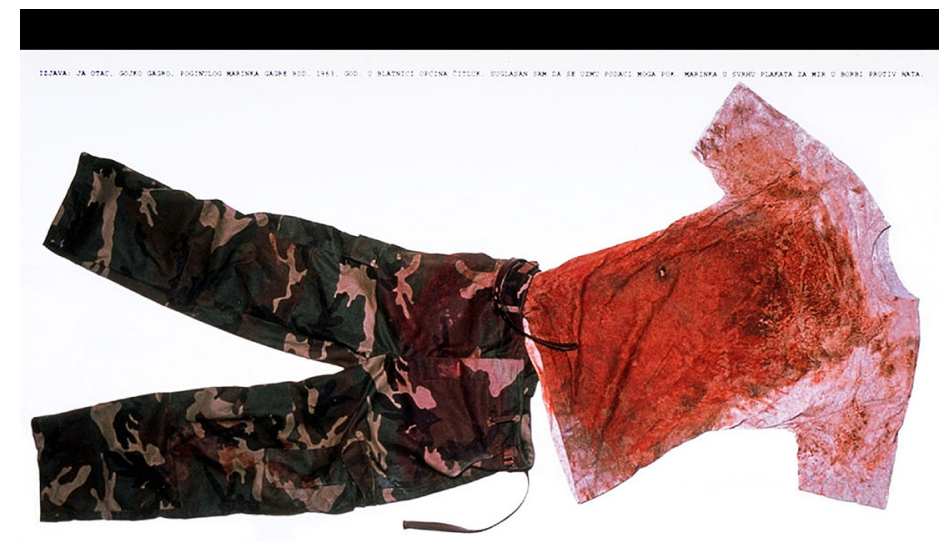

UNITED COLORS
OF BENETTON.

Fig. 1: Campaña

"Bosnia soldier"

de Benetton

(1994).

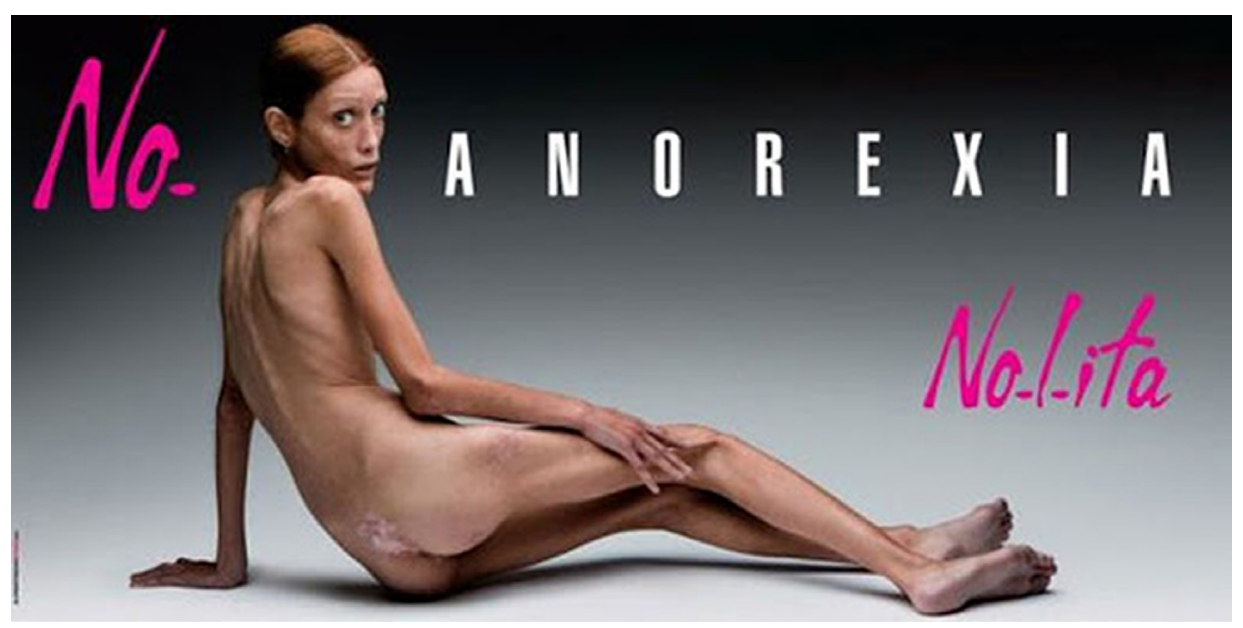

Fig. 2: Campaña de la marca Nolita (2007).

Una alternativa a la ideología toscaniana se manifiesta en campañas donde las marcas aparecen movilizadas en pos de modificar un estado de indefensión mediante el donativo. Ánimo solidario que la marca, en el rol actancial de ayudante, cumplimenta sin amenazar nunca su supervivencia por dispensar un porcentaje menor de sus ventas durante un plazo acotado (figuras 3 y 4$)$. 


\section{CADA BOTELLA AZUL AYUDA A QUE MÁS GENTE TENGA AGUA POTABLE.}

BEBER CON MODERACIÓN. PROHIBIDA SU VENTA A MENORES DE 18 AÑOS.

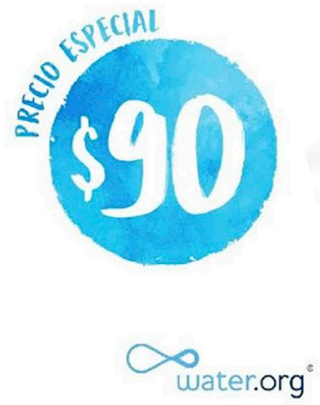

Fig. 3: Campaña de Stella Artois (2019).

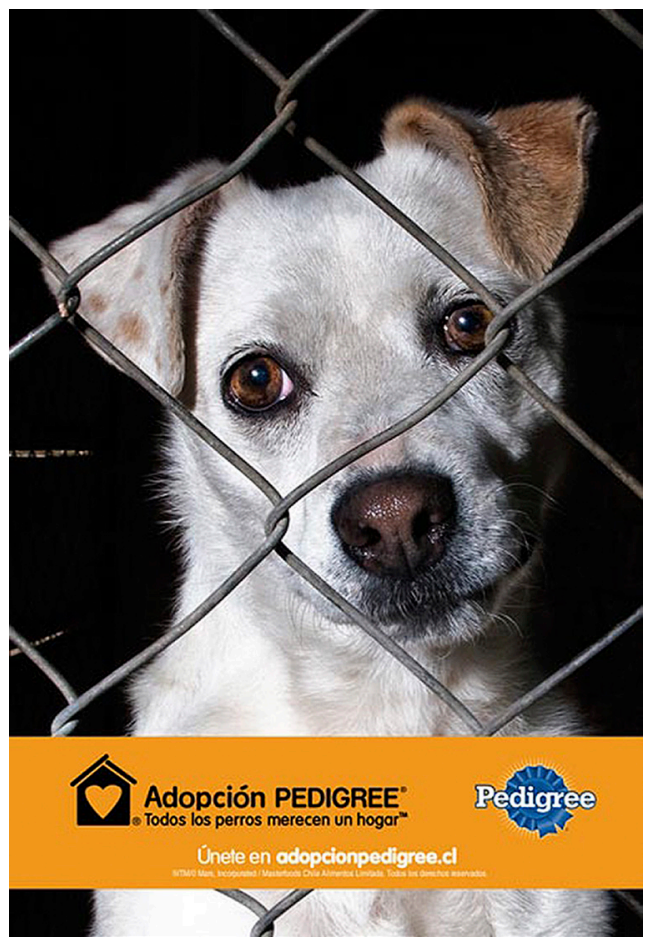

Fig. 4: Campaña de la marca Pedigree (2009).

Además de las marcas denunciantes y las contributivas, están las que quieren beneficiarse riéndose o ironizando con rapidez sobre la actualidad. Las redes sociales favorecen la inmediata viralización de estas piezas con formato de meme que retoman con ingenio un tópico de la agenda mediática a fin de realzar alguna cualidad del producto (figuras 5 y 6 ). Una estrategia que se torna peligrosa cuando la marca se pronuncia con descaro sobre un asunto candente muy doloroso o injusto. 
ES LINDO ENTERRAS UN PALO VERDE

Tึulipán neon

fluorescente

BRILLA EN LA OSCURIDAD

Fig. 5: Campaña de la marca de profilácticos Tulipán (2016), en la que refiere graciosamente al posible entierro de dinero proveniente de la corrupción de la obra pública.

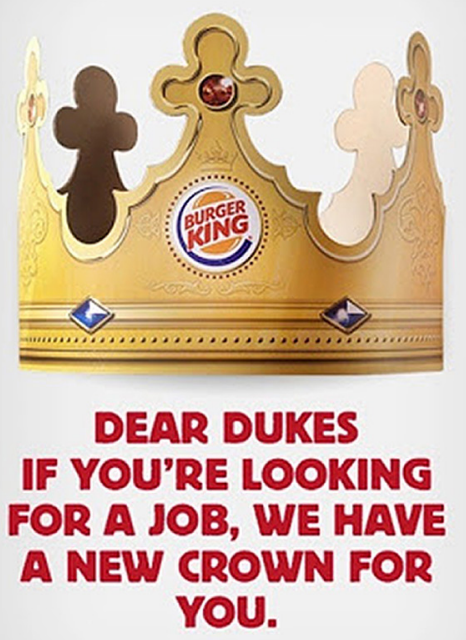

Fig. 6: Aviso de Burger King (2020) tras la decisión de los duques de Sussex de abandonar la realeza británica. 
Si en este último caso, el enunciador se inclina por ser simpático (eunoia), el tono que en realidad impera en los tres perfiles frente a lo feo, malo, disfórico es el de la franqueza que no teme las consecuencias (areté) (Barthes 1970).

De tal modo, los productos/ marca se posicionan como actores políticos que desean mejorar el bien común antes que la vida práctica de cada individuo en particular. Se apunta a un prosumidor, co-creador fan, que participe en beneficio de la empresa más allá del esperado comportamiento de compra. Quizá este tipo de mensajes de los productos/marca incremente el engagement entre los consumidores ${ }^{3}$, pero su semejanza con acciones cuya incumbencia ha recaído habitualmente en las marcas corporativas -lo que se engloba como "responsabilidad social empresaria" (RSE)-, conduce a una innecesaria confusión entre ambas voces (Centocchi 2012).

\section{Tendencias}

El contraste entre la publicidad de marca clásica y la vertiente de la publicidad posmoderna que priorizamos aquí ${ }^{4}$ permite conjeturar el rumbo que ha adoptado este tipo de discurso en los últimos tiempos. Porque si bien ambas modalidades estilísticas son contemporáneas, las campañas que se inscriben en la variante más novedosa van ganando espacio sin pausa, en cantidad y trascendencia, en desmedro de las que repiten fórmulas tradicionales.

Esta dinámica, que lleva a la consolidación de estrategias discursivas que luchan en primer lugar por captar la atención, no puede desligarse lógicamente de las profundas transformaciones en los órdenes socioeconómico, tecnológico y en las audiencias que configuran la sociedad post-industrial.

De acuerdo con lo que se ha reseñado en estas páginas, se detectan tres grandes tendencias conexas que, si consiguen imponerse definitivamente, podrían alterar de manera significativa el sistema publicitario:

a) A diferencia de discursos, como el informativo, la publicidad se orienta a dar cuenta de hábitos que forman parte del hacer cotidiano de ciertos grupos. No se centra en actos disruptivos y cambiantes que engrosan la memoria del acontecimiento, sino que representa las rutinas de la vida social (Traversa 2003). Sobre ese telón de fondo grisáceo operan los mandatos del marketing, que insisten permanentemente sobre el valor de lo nuevo y fomentan una cultura

\footnotetext{
${ }^{3}$ Según un estudio global realizado por Havas Group en 2019, el 51\% de los argentinos cree que las empresas poseen un rol más preponderante que los gobiernos para crear un futuro mejor, y el $43 \%$ dice consumir productos y servicios basados en los valores o acciones políticas, sociales de la marcas. Ver https://www.dossiernet.com.ar/articulo/meaningful-brands-las-marcas-masrelevantes-de-argentina/19192

${ }^{4}$ Fuera de la reflexión, por ejemplo, quedan las piezas que ponen énfasis en la opacidad del lenguaje por medio de juegos intertextuales o metatextuales. Ver Rodríguez Ferrándiz (2003).

${ }^{5}$ Merece mencionarse, entre otros procesos, la diversificación del universo mediático; las hipertrofias del consumo y la producción publicitaria; las fluctuaciones en los comportamientos de consumo de los individuos y la importancia que pasan a adquirir los significados en las mercancías, al margen de lo utilitario.
} 
de la innovación a través de los avances que se le atribuyen al producto/ marca.

Sin embargo, diversas piezas de la variante posmoderna, como las incluidas en el artículo (figuras 1 a 6 y 8), mellan en alguna medida dicha vocación; recurren a sucesos correspondientes al registro inestable de la actualidad, ofreciéndose así sin tapujos al espectáculo. Una ruptura de verosímil, que provocó airados rechazos y censura en sus inicios con los famosos avisos de Benetton (figura 1). La lógica competitiva de los mercados actuales parece empujar a la publicidad a unirse al "reino de la inflación acontecimental" (Nora [1974] 1978: 231). De modo superficial, porque jamás lo nuevo para esta institución que contribuye con enjundia a la cohesión social implica lo corrosivo o revolucionario.

b) El enunciador/ marca presenta siempre un punto de vista interesado sobre la realidad con el fin de emocionar antes que informar. Los recursos privilegiados que actúan en la construcción de esos universos de referencia difieren según la modalidad estilística. Disparidad que se articula con la anterior, relacionada con la sustancia del contenido.

En efecto, las historias de la publicidad de marca clásica suelen recrear conductas usuales del consumidor-tipo que derivan en estados ideales gracias al influjo del objeto comercializado. Distintas figuras de la amplificación, junto con un tono exclamativo exaltan ese triunfo invariable del optimismo. Se trata en suma de ficcionalizaciones que si bien establecen ciertos puntos de contacto con la realidad factual nadie sostendría que ocurren verdaderamente.

La publicidad posmoderna, en cambio, ha pasado a acentuar el momento inicial de falta. Toma problemas e individuos concretos que no siempre se tipifican. La autenticidad es un aspecto importante del contrato entre la marca y sus clientes. Por ello, el enunciador se involucra en asuntos de gran repercusión pública, dados a conocer por múltiples metadiscursos que confirman su existencia; de lo contrario, necesita respaldarse en el código documental, verista para que el anclaje real no se ponga en duda en la instancia de reconocimiento. Interviene así una serie de operaciones significantes para que el receptor se incline a otorgarle a este tipo de campañas un mayor grado de adscripción al régimen no ficcional (en contraposición a cómo actúa habitualmente frente a cualquier publicidad).

c) En términos de la semiótica greimasiana, las diferencias que se registran en los niveles de superficie y narrativo revelan la heterogeneidad de valores básicos preferenciales que transmite cada gramática desde el estrato más profundo, el axiológico (Semprini 1995).

La publicidad tradicional fomenta una ética marcaria en la que incentiva el consumismo. Solo es posible conquistar el bienestar personal o familiar (felicidad confort, amor, vitalidad) si se tiene/ consume determinado "agente mágico". Se promete de este modo una redención egoísta que lo singularizará (en muchos casos incluirá un ascenso en la jerarquía social). 
La publicidad posmoderna pregona otra clase de ética a través del tratamiento de cuestiones de dominio público que no afectan la vida diaria del destinatario. Pero constituyen causas colectivas que lo interpelan en su humanidad, como habitante de un planeta lleno de dificultades. Se busca que el cliente muestre su adhesión a valores inherentes a las HumanBrands (sostenibilidad, transparencia, solidaridad, respeto a la diversidad) (Requena 2012) a partir de la compra 6 . Funcional al negocio, el consumidor se conduce así porque quiere apropiarse esta vez del valor simbólico de la marca para demostrar fraternidad e identificación con otros.

El nuevo aparato, el político recientemente electo, el personaje de una película o los destinos turísticos codiciados de hoy pueden convertirse en los íconos culturales del mañana. Lo mismo ocurre con las marcas, que pueden trascender las categorías de productos de las cuales surgieron para alcanzar el estatus de ícono cultural, si es que pueden convertirse en símbolos de peso para un conjunto de valores o ideales que resuenan dentro de una sociedad o cultura (Batey 2013: 300).

\section{Consideraciones finales}

La variante posmoderna, fundada por distintos modos de hacer que comparten el gesto vital de infringir reglas de la variante clásica, parece comprometerse con decir verdad. Por vías disímiles, tanto la vertiente que compatibiliza con discursos de preeminencia referencial (informativo, científico médico) -focalizada en este artículo-, como la vertiente que pone en juego mecanismos autorreflexivos, promueven un efecto de sinceridad.

La publicidad posmoderna avanza con su apuesta desautomatizadora, que obsequia rupturas e hibridaciones, pese a los cuestionamientos que aún despierta. Únicamente la evidencia empírica que verifique su ineficacia persuasiva podría decretar el principio de su declive.

Como nunca antes las marcas -remitan a un producto, compañía o individuo- se esmeran por gestionar el proceso dialógico que sustenta su reputación porque indica el grado de credibilidad, confianza y coherencia que se le asignan. Dicha percepción colectiva puede favorecer o perjudicar seriamente el poderío económico, simbólico, de esa entidad.

Variados actores, ajenos incluso a la esfera comercial, se preocupan actualmente por el tema. En torno a la reputación se originan conflictos que se vuelven más recurrentes a medida que crece este desvelo.

Los productos/ marca se hallan implicados a menudo en esta clase de disputas: sean ejecutores o víctimas de la maniobra que se entiende como lesiva del prestigio. Observemos a continuación dos casos opuestos con resonancia

\footnotetext{
${ }^{6}$ Lo comunicacional forma parte del llamado "Marketing Sustentable", que procura desarrollar un modelo de negocios preservando el planeta y favoreciendo la inclusión social.
} 
pública muy próximos en el tiempo (mayo de 2019):

a) Un conocido humorista gráfico argentino, Nik, divulgó a través de su cuenta de Twitter una viñeta donde se aludía sin autorización a la marca de tarjetas de crédito Naranja. Un chiste machista que enseguida recibió el repudio de miles de usuarios (figura 7).
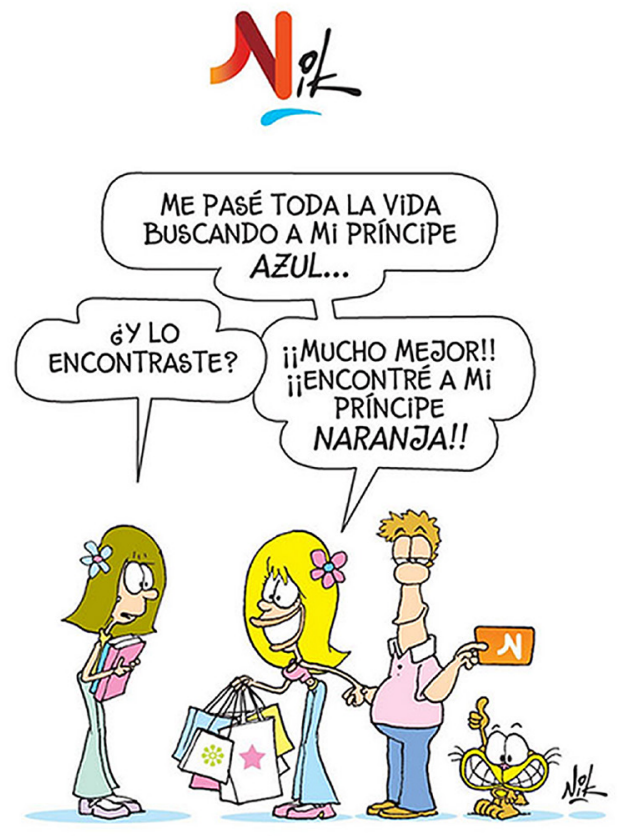

Fig. 7: El chiste de Nik que desencadenó la ira generalizada (2019).

Frente al revuelo, la marca se desligó rápidamente de la acción por medio de un contundente mensaje que compartió por sus redes sociales: "Todos los que hacemos Naranja queremos aclarar que no tenemos relación alguna con la publicación de hoy de @Nikgaturro. Ya solicitamos vía legal que se elimine, por oponerse a nuestros valores y utilizar nuestra identidad sin consentimiento alguno" (20-5-2019, 15.32hs). A los pocos minutos, Nik eliminó la publicación sin ofrecer ningún descargo.

b) Por el lanzamiento del nuevo Polo en 2017, Volkswagen (VW) realizó un aviso gráfico de contenido político que incluía de fondo la obra Soleil Levant del artista Ai Weiwei. La instalación, creada especialmente para el Día Mundial del Refugiado de aquel año, se compone de 3500 chalecos salvavidas usados por migrantes que vivieron la terrible travesía del cruce del mar Mediterráneo en busca del continente europeo (figura 8). 


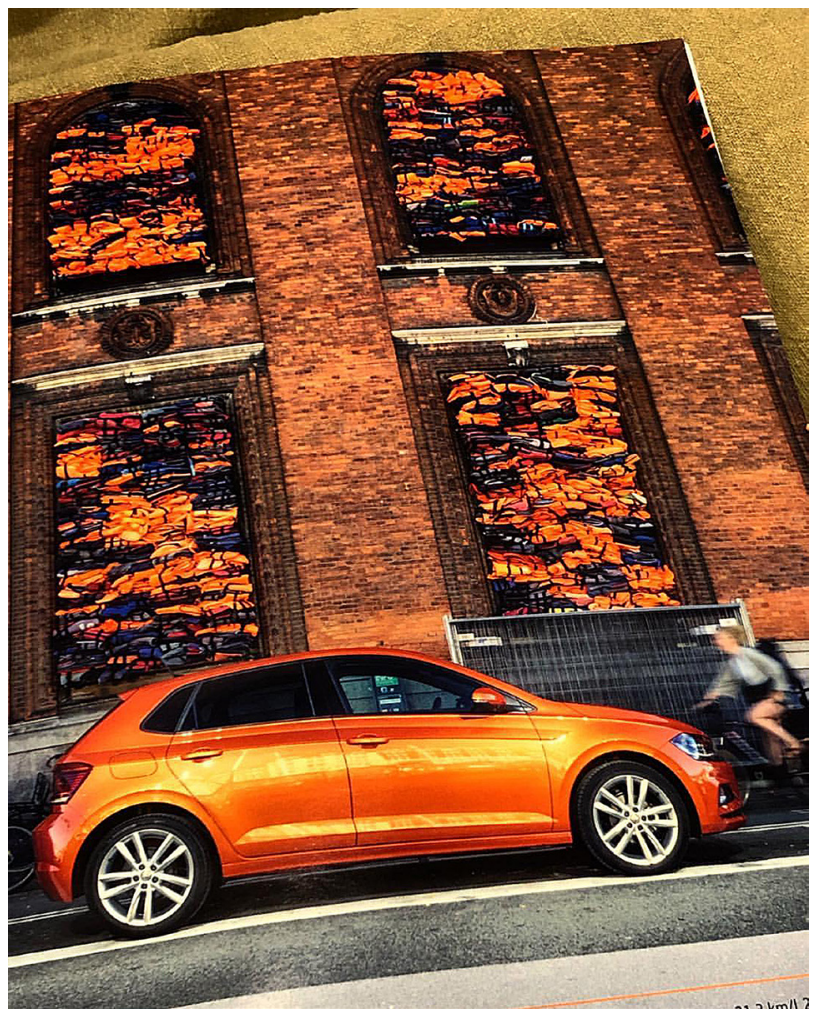

Fig. 8: Aviso de Volkswagen Polo (2017).

Al enterarse, el artista chino trató primero de resolver la violación de modo amistoso, pero luego de más de año sin resultado decidió iniciar un juicio. Compartió un alegato, que reprodujo la prensa, en el que explica porqué pretende una reparación legal:

Como artista, debo enfrentar serias consecuencias si mi arte es mal utilizado. La publicidad sugiere falsamente que yo he dado permiso para que mi obra sobre los refugiados venda autos de Volkswagen. Esta falacia daña gravemente mi reputación artística y una vida de trabajo defendiendo los derechos humanos (...) Este perjuicio compromete mi credibilidad y podría destruir la confianza que he construido con los refugiados a los que ayudo con mi trabajo ¿Por qué se asociarían conmigo los refugiados, si creen que voy a usar su sufrimiento para obtener beneficios económicos? (Weiwei 2019: 10).

En ambos incidentes se produce la colisión entre dos marcas que velan por sus respectivas imágenes, donde una de ellas se considera damnificada por partida doble: se vulneran sus derechos de propiedad intelectual y se lesiona su prestigio. El último ejemplo merece destacarse ya que el aviso de VW Polo responde justamente a la modalidad posmoderna, al afán por des-ficcionalizar la publicidad a través del empleo de operaciones autentificantes. 
En este sentido, la cita a Soleil Levant le permite al enunciador/ marca hacer referencia con conciencia social al mundo "real" sin "mediaciones". VW Polo renuncia de tal manera voluntariamente a crear su propio mundo posible para tomar posición respecto a una calamidad tangible como las desesperadas migraciones de africanos (Semprini 1995).

A principios de los años '90, "la verdadera causa de los ataques que ha sufrido la comunicación de Benetton (fue) el pretender erigirse en sujeto de derecho legitimado para delimitar y divulgar los problemas de la sociedad" (Semprini 1995: 219). Evidentemente, por el papel central que han adquirido las marcas comerciales en el espacio sociocultural, esa controversia de índole enunciativa terminó a su favor. Ahora el desafío principal es otro. Más sutil. Radica en cómo las marcas comunican de manera fehaciente su intervención en lo "real" sin molestar ninguna sensibilidad individual o grupal, sin trasgredir un copyright. El ascendente verosímil de la corrección política no disuelve todas las barreras.

\section{Bibliografía}

ADAM, Jean-Michel \& Marc BONHOMME. 1997. L'argumentation punblicitaire. Rhétorique de l'éloge et de la persuasión. Paris: Nathan.

BARTHES, Roland. 1970. Recherches Rhétorique. Communications 16. Paris: Seuil.

BATEY, Mark. 2013 [2008]. El significado de la marca. Cómo y por qué ponemos sentido a productos y servicios. $1^{\circ}$ edn. en castellano. Buenos Aires: Granica.

CENTOCCHI, Claudio. 2012. Las marcas predicadoras: ¿filosofía o negocios? Paper presentado en el X Congreso de la Asociación Internacional de Semiótica Visual, Universidad de Buenos Aires, 4-8 Setiembre.

COSTA, Joan. 2004. La imagen de marca. Un fenómeno social. Barcelona: Paidós.

CHAVES, Norberto. 1988. La imagen corporativa. Barcelona: Gustavo Gili.

FLOCH, Jean-Marie. 1990. Tués dans l'oeuf. Sémiothique, Marketing, et Communication. Sous les signes, les stratégies, 183-226. Paris: PUF.

GENETTE, Gérald. 1982. Palimpseste. La littérature au second degré. Paris: Seuil.

KLEIN, Naomí. 2000. No logo. Taking aim at the brand bullies. Toronto: Knof Canada. 
KOTLER, Philip. 1990. Marketing Management, Análisis, Planning, Implementation \& Control. Prentice-Hall.

KRIEF. Yves. 1984. Jeux du publicité. Les conditions postmodernes de la publicité. En VV.AA. Sémiotiques II, 213-253. Paris: IREP.

Meaningful Brands: las marcas más relevantes de Argentina. (2019) https:// www.dossiernet.com.ar/articulo/meaningful-brands-las-marcas-masrelevantes-de-argentina/19192 (accesed: 29 January 2020).

NORA, Pierre. 1978 [1974]. La vuelta del acontecimiento. En Jacques LE GOFF \& Pierre NORA, Hacer la historia I. Nuevos problemas, 221-239. Barcelona: Laia.

PEIRCE, Charles S. 1978 [1895 1902]. La ciencia de la semiótica. Buenos Aires. Nueva Visión.

REQUENA, Gema. 2012. LoveMarks vs HumanBrands, los nuevos valores de marca. Anuncios 1435. 24-25.

RODRÍGUEZ FERRÁNDIZ, Raúl. 2003. Publicidad omnívora, publicidad caníbal: el intertexto polémico. Paper presentado en las I Jornadas de Publicidade e Comunicaçao. Universidade da Beira Interior, noviembre.

SÉGUÉLA, Jacques. 1984. Hollywood lave plus blanc. Paris: Flammarion.

SEMPRINI, Andrea. 1995. El marketing de la marca. Una aproximación semiótica. $1^{\circ}$ ed. en castellano. Barcelona: Paidós.

2006. La marca postmoderna. Potere e fragilità della marca nelle societá contemporanee. Milano: Franco Angeli.

TASSARA, Mabel. 2002. Las figuras argumentativas en el discurso publicitario. Paper presentado en el Congreso Internacional: La argumentación: Lingüística, Retórica, Lógica, Pedagogía. Universidad de Buenos Aires.

TRAVERSA, Oscar. 2003. Las memorias de la publicidad. Figuraciones1-2. 187201.

VERÓN, Eliseo. 1987. La semiosis social. Fragmentos de una teoria de la discursividad. Buenos Aires: Gedisa.

WEIWEI, Ai. 2019. El artista Ai Weiwei, indignado con Volkswagen: usaron su obra para un aviso. https://www.clarin.com/cultura/artista-ai-weiweiindignado-usaron-obra-aviso_0_9Z5eyfJZW.html (accesed: 29 January 2020). 


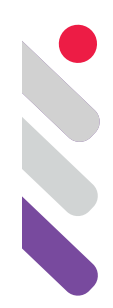

\title{
La construcción del destinatario en la Marca País Argentina
}

DOI: 10.24308/IASS-2019-5-017

\author{
Fiorini, Daniela y Socolovsky, Paula \\ Facultad de Arquitectura, Diseño y Urbanismo, \\ Universidad de Buenos Aires, Argentina \\ fiorinidaniela@gmail.com / paula@blaunt.com
}

\section{Introducción}

Este trabajo forma parte de la investigación iniciada en 2015 por la cátedra Fiorini de Semiología en FADU, UBA. El objetivo de este trabajo es pensar al diseño gráfico como partícipe fundamental de las políticas de identidad nacional. Nuestro objeto de estudio será el concepto de marca país. Sostenemos que el Diseño Gráfico de Identidad Visual, dentro del cual el concepto de identidad de marca país constituye una de sus principales producciones, constituye un género discursivo, atravesado por distintas retóricas y modos de enunciación. Si bien se han hecho numerosos análisis retóricos sobre las marcas que conforman la identidad visual de un país o de una ciudad, la relación entre esta retórica y la enunciación muchas veces ha sido soslayada, dejando de lado aspectos comunicacionales del diseño.

Guy Julier (2010) advierte sobre la creciente importancia del branding como motor de gran parte del ejercicio del diseño y señala al respecto dos retos claros: el primero es que la cultura del diseño exige al observador ir más allá de los atributos visuales y materiales para considerar las redes multidiversas y multilocacionales de su creación y manifestación. Este autor plantea que la marca país se encuadra en el concepto de branding de lugares, proceso en el que, para posicionar una ciudad, una región o un país se diseñan marcas icónicas que representan los mitos de identidad de un lugar. En consonancia con estos planteos, la marca país Argentina será analizada desde la perspectiva de la semiótica del diseño y el análisis del discurso. Nos parece relevante aplicar el análisis del discurso al estudio del diseño, ya que esta disciplina propone analizar el diseño en su contexto, y en su dimensión de construcción de sentido. 


\section{El diseño de marca país y la construcción de identidad cultural}

Si bien se han escrito muchostextos sobre el concepto de marca-país, casi todos los estudios producidos desde el diseño analizan el fenómeno desde una perspectiva formalista.Entre los diseñadores que han teorizado sobre el concepto de marca país, se destaca la perspectiva de Norberto Chaves (1994), para quien el "correcto" diseño de la marca país debe poseer capacidad emblemática, pertinencia tipológica y estilística, entre otros atributos. Norberto Chaves, define a la identidad institucional como un conjunto de atributos asumidos como propios por la institución, señalando además que la Identidad Visual es el registro público de los atributos identificatorios del sujeto social. Para Chaves el "buen diseño" de la marca país se caracterizará por la estridencia, legibilidad, pregnancia y reproducibilidad. Podemos observar, en esta definición predomina una perspectiva estrictamente profesionalista, para la cual el diseño tiene un fin utilitario y se propone comunicaratributos esenciales y significados unívocos. El fin último de esta teoría del diseño es generar una comprensión general y formal de la marca país, sin tomar en cuenta los contextos discursivos complejos en los que seráinterpretada.

Jorge Frascara (1988) también ha trabajado en sus escritos, la idea de que el diseño debe ser lo más transparente posible, y plantea que la figura del diseñador no debe evidenciarse o notarse. Parece que el "buen diseño" se identifica con una sola metáfora posible: la "economía de recursos", la "neutralidad", la "desaparición del autor". En este sentido, Frascara señala que "un diseñador trabaja en la efectividad, la belleza y la economía de los mensajes". En síntesis, en sus distintas variantes teóricas, estos autores piensan al diseño como neutro y "apolítico".Esta visión despoja al concepto de marca país de un amplio rango de posibles significaciones complejas, ambiguas y culturalmente variables.

Frente a estas concepciones restringidas, autores como Guy Julier (2010) piensan al diseño en el marco de la cultura, desde una perspectiva transdisciplinaria que pretende reflexionar de manera compleja. Esto implica no limitarse a un análisis morfológico del objeto y de las intenciones de los diseñadores, sino entender al diseño inserto en un marco cultural que incluye la producción, la circulación y el consumo. En consonancia con estos planteos el autor, la marca país representa la cultura de un país y sus múltiples mitos de identidad. Siguiendo a Julier, nos proponemos relacionar los discursos del diseño (Gráfico y de Identidad Visual) con los procesos económicos y políticos y con la construcción identitaria de un país.

\section{La marca país como género discursivo}

A partir de los aportes de Oscar Steimberg (2013) sobre la teoría sobre los géneros discursivos de Mijaíl Bajtín (2002), se trabajará al diseño de marca 
país como un género discursivo que "marca el tono de una época", en estrecha relación con la vida social y cultural. El diseño de marca país puede considerarse un género discursivo propio del diseño gráfico. El género será definido como una "serie de enunciados o discursos relativamente estables" (Bajtin1982). El autor define el efecto de previsibilidad y las articulaciones históricas como una condición de horizontes de expectativas que operan como correas de transmisión entre la historia de la sociedad y la historia de la lengua. Es decir, el diseño gráfico de identidad visual desarrolla una serie de formas visuales que crean discursos que son, además, históricamente reconocibles.

Desde esta perspectiva, el diseño no es una suma de signos aislados sino un conjunto de discursos que circulan por la sociedad. La noción de discurso, se refiere tanto al texto (verbal o visual) como a su contexto cultural, social y político. Para Steimberg, para que un grupo de objetos pertenezcan a un mismo género discursivo, es necesario que compartan ciertas características temáticas, retóricas y enunciativas. Es clave el análisis de la enunciación, vinculada a los sujetos que producen los discursos y a su relación con los enunciatarios.

Por otra parte, para Eliseo Verón (1987) toda producción de sentido tiene una manifestación material. El punto de partida de la semiosis son paquetes de materias sensibles investidas de sentido (productos), configuraciones de sentido identificadas sobre un soporte material (texto lingüístico, imagen, etc.).Así, los productos de diseño de la identidad visual de marca país reunen las condiciones materiales y discursivas suficientes como para ser analizados bajo esta teoría.Consideraremos también las conceptualizaciones de Verón (2004), relativas a las gramáticas de producción y reconocimiento de los discursos. Es aquí donde se ponen en juego los imaginarios que se construyen tanto en el proceso de enunciación como en los modos de recepción. Estos "contratos de lectura" pueden darse en forma pedagógica, cómplice u objetiva, dependiendo de la distancia y simetría que se establece entre el enunciador y el enunciatario.

El diseño de identidad visual muchas veces utiliza un estilo gráfico que pretende la invisibilización del enunciador y del destinatario. Es por esto que tanto el diseño gráfico y sus producciones de identidad visual como la imagen de marca de un país deben ser analizados desde su dimensión discursiva. La marca de un país construye sentidos en sus múltiples destinatarios y genera discursos complejos sobre la identidad cultural.Desde nuestra perspectiva, el destinatario cumple un rol central en la construcción y legitimación de discursos vinculados al diseño de marcas e identidades. A la luz de estas consideraciones, realizaremos un análisis diacrónico de las marcas país de Argentina, desde 2005 (y su rediseño en 2012) hasta 2018. 


\subsection{El discurso de la marca país Argentina 2005-2012}

Se pueden reconocer temáticas (figura 1 ) que se asocian tanto a la representación del país (Argentina), como a los distintos símbolos patrios relacionados con la nacionalidad (bandera, escudo, escarapela). El contenido apunta a la construcción de Argentina como nación y a la representación de la diversidad del país. Se construye un relato o una narrativa ligada a la identidad nacional.

En cuanto a la retórica,se presentan algunas metáforas, a partir de formas abstractas, como la del espacio geográfico del territorio argentino, de los Andes a la costa Atlántica, representado por las formas curvas del isotipo. Estas formas curvas sugieren una geografía diversa, que va de la cordillera al océano, que incluye montañas, llanuras y costa marítima. Por otra parte, las formas curvas entrelazadas son dinámicas y pueden ser interpretadas como cintas en movimiento, relacionadas con el cambio y la transformación. El origen común de estas formas, que luego se diversifica, apoya el discurso de "diversidad en la unidad".

En relación a las elecciones cromáticas se utiliza una paleta de colores asociados a los símbolos patrios argentinos, de color celeste, azul blanco y gris, en la primera versión de 2005. En esta versión el gris hacía referencia a la asociación con la innovación y la tecnología de vanguardia. En la segunda versión de 2012, se cambia el gris por el amarillo, que refuerza la relación con la bandera argentina y con el logo del Bicentenario.

Por último, la tipografía, sansserif, en la primera versión es light y está acotada en el espacio, de acuerdo a una grilla constructiva que une el logo con el isotipo. En la versión de 2012 gana protagonismo la tipografía, cambio destinado a favorecer la identificación y reconocimiento de la misma por parte del destinatario.

La figura del enunciador, es decir, de aquel que produce el discurso, puede desdoblarse analíticamente. Por un lado, el enunciador más visible es el Estado Nacional, que toma la decisión política de generar un diseño de identidad para el país. Este enunciador se identifica con el modelo político que gobernó el país entre 2003-2015 (gestiones de Néstor y Cristina Kirchner), y su discurso con énfasis en las temáticas nacionales y populares. El modelo de enunciador es el Estado, que usa esta marca en sus comunicaciones visuales, intentando centralizar la identidad en el país o nación. La idea de esta marca era reinsertar al país luego de la crisis de 2001, convocando a sectores públicos y privados. Se planteaba la recuperación de la autoestima como nación y la necesidad de competir en el mundo con bienes y servicios argentinos. Por otro lado, hay un segundo enunciador constituido por los diseñadores de la marca (elegida por concurso), que quedan invisibilizados en el discurso.

En cuanto a las figuras del destinatario también podemos reconocer 
distintos tipos de destinatario. Por una parte, el enunciatario modelo es una institución, empresa o ciudadano (argentino o extranjero) que puede interpretar los atributos de la argentinidad y reconocer la marca fácilmente. En teoría, la marca construye condiciones de reconocimiento pedagógicas y claras, que dirigen la interpretación del destinatario al reconocimiento de los rasgos pertinentes de la argentinidad. Este ciudadano modelo es interpelado por la marca, buscando la identificación de la misma con un relato de recuperación del valor del país. Tomando la categorización de Eliseo Verón (1987), el prodestinatario de la marca es el ciudadano argentino que se siente identificado con un proceso (político, social y económico) de revalorización del país.

Sin embargo, el destinatario empírico, por la solemnidad de la marca (asociada a los símbolos patrios) y por el desconocimiento de su discurso (relato de recuperación nacional) no lograba reconocerla y recordarla. En este sentido, la marca era resistente a la apropiación por parte de un destinatario no institucional. Según esta interpretación, el enunciador, en su extrema pedagogía resultaba distante, ya que no lograba una complicidad con su destinatario empírico: el ciudadano común o el público "lego".

Por otra parte, podemos esbozar un tercer tipo de destinatario, más crítico y autoconsciente: el diseñador. Algunos diseñadores elogiaron a la marca por sus condiciones formales: síntesis, pregnancia, legibilidad. Pero también el diseño fue criticado por la falta de representatividad de la diversidad cultural argentina, entre otros argumentos.

\subsection{El discurso de la marca país Argentina 2018}

La temática es difícil de identificar a primera vista, ya que no queda claro cuál es el referente de la imagen presentada (figura 1). Si se avanza en el análisis se puede vincular con la idea de tecnología y modernidad, y secundariamente con la ubicación de Argentina en el mundo.La imagen se reconoce como marca pero no parece representar a un país, región o ciudad. La marca es genérica, ya que podría pertenecer a cualquier ámbito de la imagen corporativa (empresa, institución). No contiene referencias temáticas al Estado o a la nación.

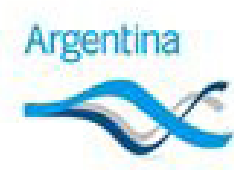

2005

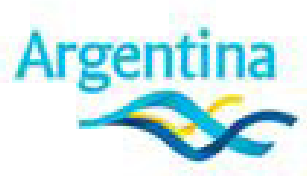

2012

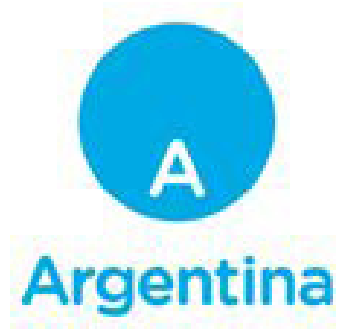

2018

Figura 1. Las tres versiones de marca país Argentina. 
En cuanto a la retórica,la representación es abstracta y minimalista, constituye un círculo plano con una letra A dentro. La marca se presenta como un círculo vacío de sentido, destinado a ser completado en distintas aplicaciones gráficas. En dichas aplicaciones, sin embargo, cuesta reconocer la marca, y en algunos casos se desvanece totalmente. El emplazamiento de la $\mathrm{A}$ en la parte inferior del círculo se propone representar una marcación geográfica, la ubicación de la Argentina en el sur del continente americano. Sin embargo, la imagen es polisémica y puede ser leída con una connotación negativa. Como indica el estudio de Lakoff \& Johnson (2017) sobre las metáforas de la vida cotidiana, la orientación espacial "abajo" está vinculada al concepto de "peor", "malo" y de status inferior. Según los autores: "bueno es arriba, malo es abajo", "más es arriba, menos es abajo", "tener control o fuerza es arriba, estar sujeto a control o fuerza es abajo".

En relación al color, la marca es monocromática, retomando el celestecyan de la marca anterior, único punto de contacto entre ambos diseños. En relación a la tipografía (GothamRounded), se utiliza en esta marca proponiendo una retórica "neutra". Estas tipografías sans-serif, que no terminan en formas duras y rígidas, le aportan un carácter "informal" y hasta "infantil". En este sentido, la tipografía sans-serif funciona como una nueva Helvética ya que marca una sincronía con otras identidades corporativas contemporáneas. El logo tiene una fuerte interdiscursividad con apps globalizadas como Mashable y Telegram. Esta intertextualidad refuerza la idea de tecnología pero desvanece el concepto de Estado-nación.Por otra parte, la tipografía presenta una similitud estratégica con la tipografía del partido político Cambiemos, que gobernó el país en el período 2015-2019. Aunque esta decisión retórica pueda pasar inadvertida, se utiliza la tipografía de un partido para representar al país, generando efectos en la enunciación.

Si bien el enunciador empírico es el Estado, el enunciador modelo intenta desvincularse de la relación política con el país Argentina. No aparece representado el Estado o la nación en ningún aspecto gráfico, excepto la letra A, y la palabra "Argentina" en el enunciado. En este sentido, el modelo de enunciador podría ser el de una empresa privada o start-up de cualquier lugar del mundo. El otro enunciador en juego es el diseñador. El diseñador empírico es el estudio de diseño y publicidad FutureBrand, que también participó en el rediseño de la marca país Argentina 2012. El diseñador modelo está invisibilizado como enunciador, ya que no tiene ningún protagonismo en términos estilísticos, dado que predomina el "estilo del no estilo". El enunciador-diseñador no está asociado a tendencias locales sino a un estilo más bien internacional propio del siglo XXI y de las redes sociales.

El primer modelo de destinatario es tan anónimo y apolítico como el enunciador. El diseño no le demanda competencias culturales específicas que 
permitan asociarlo a un país o nación. El enunciador construye un contrato de lectura distante (objetivo), que no genera espacios de complicidad entre enunciatarios. Este primer modelo de destinatario no se siente interpelado emocionalmente por la marca, ya que las marcas de la enunciación están borradas deliberadamente. Esta marca "vacía" sostiene la idea de un autor anónimo que le habla a un destinatario también anónimo. En esta variante un Estado que pretende invisibilizarse como enunciador construye un destinatario apolítico, que no es interpelado como ciudadano.

Se puede postular un segundo modelo de destinatario, que es el prodestinatario del proyecto político del partidogobernante. Este prodestinatario está construido a través del uso cómplice de la tipografía oficial del partido en comunicaciones no partidarias. Este destinatario no se siente identificado con la idea de Nación o Estado, sino con un proyecto político y económico que plantea la inserción de Argentina en un mundo globalizado, a costa de operaciones de vaciamiento cultural eidentitario, entre otras.

Un tercer modelo de destinatario son los diseñadores, que realizan la lectura experta, crítica y especializada de la marca. En este sentido la marca despertó una gran polémica, y se criticó su excesivo racionalismo y minimalismo, la falta de capacidad emblemática y de carácter institucional y la ausencia de un relato nacional representativo.

\section{Consideraciones finales}

El objetivo de este trabajo fue argumentar que el diseño desde sus diferentes prácticas es un protagonista privilegiado de las políticas de identidad nacional. En las investigaciones realizadas en estos últimos años podemos actualizar esta premisa de cara a los cambios de gobierno en la Argentina, que fueron acompañados por cambios discursivos y transformaciones en el diseño.

A través del análisis de la identidad visual de la marca país se puede establecer el papel del diseño en la generación y legitimación de discursos políticos. El diseño en la modernidad, según Robin Kinross (1989), se basa en la idea de neutralidad, planteando un discurso vacío y despolitizado. Sin embargo, para Kinross, "nada está libre de retórica y los vacíos ideológicos no existen". El modelo de análisis que proponemos en nuestra materia implica relacionar los discursos del diseño con los procesos económicos y sociales. El diseño tiene una dimensión política y participa activamente en la construcción o deconstrucción de la identidad de un país.

Observamos que el diseño y la identidad visual son protagonistas indispensables en la producción de los discursos sociales. Tal como aparece en el material relevado, ambas marcas país construyendiscursosmuy diferenciados sobre la identidad nacional y cultural, vinculados a diferentes proyectos políticos. Según Miriam Greenberg (2008), el branding de una ciudad, tanto como el de 
un país, tiende a unificar el discurso alrededor de un imperativo económico y político. De esta manera, sirve para construir una visión hegemónica sobre estos, impidiendo ver los conflictos internos y captar la complejidad de los lugares. Asimismo, Greenberg teoriza sobre la relación existente entre el marketing de lugares, los procesos de reestructuración económica y las políticas neoliberales.

En este sentido, es un fenómeno digno de reflexión el diseño de identidad visual de la marca país 2018, que practica un estilo gráfico que pretende la invisibilización del enunciador, en tanto Estado-nación. Observamos que la "retórica de la neutralidad" fue visible en otras áreas del diseño estatal del período 2015-2019, por ejemplo, en el diseño de monedas y billetes, en las redes sociales gubernamentales, en las campañas de comunicación visual de los ministerios, o en la construcción de la imagen del Bicentenario 2016. En estos casos, las condiciones de producción del discurso tienden a invisibilizar el rol del Estado, construyendo un destinatario que no se siente interpelado como ciudadano, sino como consumidor.

Si pensamos al diseño como partícipe fundamental de las políticas de imagen, resultará indispensable ubicar a las prácticas de diseño como productoras y reproductoras de sentido. El diseño, lejos de ser el mero portador de un supuesto "valor estético", también cumple un rol ideológico en la legitimación de proyectos políticos y económicos.El diseño es indisoluble de la trama cultural en la que se encuentra inscripto, en la complejidad del campo de la comunicación. La imagen diseñada es ofrecida como una naturalidad aparente, pero se construye a partir de procesos de intermediación, que no solo intentan cumplir un objetivo de comunicación (en el sentido de transmisión de información), sino que construyen imaginarios e identidadesculturales y sociales.

\section{Referencias bibliográfícas}

BAJTIN, Mijail. 2002. "El problema de los géneros discursivos", en Estética de la creación verbal, México, Siglo XXI, 1952.

CHAVES, Norberto. 2011. La marca-país en América Latina, Buenos Aires, La Crujía.

(1994) La imagen corporativa. Madrid, G. G.

FRASCARA, Jorge. 1988. Diseño gráfico y comunicación. Buenos Aires, Infinito.

GREENBERG, Miriam. 2008. "Branding the neoliberal city", enBranding New York, How a City in Crisis Was Sold to the World, Routledge.

JULIER, Guy. 2010 "Branding de lugares”, en La cultura del diseño, Barcelona, Gustavo Gili. 
KINROSS, Robin. 1989. "The Rethoric of Neutrality", enDesign Discourse, History / Theory / Criticism, ed. Victor Margolin, Chicago, The University Press.

LAKOFF, George, JOHNSON, Mark. 1986. Metáforas de la vida cotidiana, Madrid, Cátedra.

STEIMBERG, Oscar. 2013. "Texto y contexto del género", en Semióticas. Las semióticas de los géneros, de los estilos, de la transposición, Buenos Aires, Eterna Cadencia.

VERÓN, Eliseo. 2004."Cuando leer es hacer: la enunciación en el discurso de la prensa gráfica", enFragmentos de un tejido, Buenos Aires, Gedisa.

1987. "La palabra adversativa. Observaciones sobre la enunciación política”, en AA. VV., El discurso político. Lenguajes y acontecimientos. Buenos Aires. Hachette, 1987. 


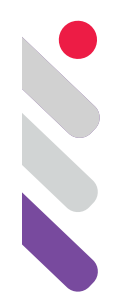

\section{Semiótica aplicada: análise de peças da marca Gatorade à luz da teoria peirceana}

Gabriel Moni de Souza

Universidade de São Paulo, São Paulo, SP

gabrielmonidesouza@gmail.com

Heder Seitiono

Universidade de São Paulo, São Paulo, SP

heder.ono@gmail.com

Maria Clotilde Perez

Universidade de São Paulo, São Paulo, SP

cloperez@terra.com.br

\section{Introdução}

O presente trabalho que nasceu na disciplina de Semiótica e Rituais do consumo do programa de Pós-Graduação da ECA-USP, busca compreender as especificidades e caminhos da semiótica aplicada por meio de análise semiótica Peirceana de duas peças publicitárias já veiculadas da campanha "Gatorade Always Wins", verificando se todo potencial comunicativo dos anúncios está em sintonia com a atmosfera da marca e com o provável ideal de criação. Para tal, são utilizados como principais bases teóricas os conceitos de Charles Sanders Peirce, Lúcia Santaella, Clotilde Perez e Winfried Nöth.

A semiótica é a ciência que estuda todos os tipos de signo e as condições necessárias para a transmissão de significado de uma mente a outra ou de um estado mental a outra (Bacha 2005). Ja análise parte inicialmente da fenomenologia, que segundo Santaella (2012), tem por função apresentar categorias formais e universais dos modos como os fenômenos são aprendidos pela mente.

Segundo Santaella (2002), os estudos de Peirce levam a três elementos formais e universais nos fenômenos que se apresentam à percepção e a mente, denominadas como primeiridade, secundidade e terceiridade. A primeiridade tem relação com o acaso, possibilidade, qualidade, sentimento, mônada. A secundidade possui relação com a dependência, ação e reação, aqui e agora. 
Por fim, a terceiridade diz respeito a generalidade, crescimento e inteligência.

A escolha da marca e da campanha que seria analisada foi baseada no corpus de estudo dos dois pesquisadores, o esporte e o antropomorfismo. Segundo Perez (2016), a marca consegue incorporar características de identidade e representação, e portanto, é um signo de acordo com a noção peirciana de que signo é "alguma coisa que representa algo para alguém".

\section{Referencial Teórico}

De acordo comPerez (2016), seguindo a teoria de Peirce e sua concepção triádica, um signo é qualquer coisa que por sua vez está no lugar de qualquer coisa para ser interpretada por alguém. Peirce fala sobre a relação entre três elementos: representamen, object e interpretant.

Representamen é o nome peirceano "objeto perceptível" servindo como signo do receptor. Podendo segundo Peirce, ser o signo considerado do ponto de vista "da sua própria natureza material" ou "como é em si mesmo" (Noth 2003).

Segundo Peirce, o objeto corresponde ao referente. O objeto pode ainda ser uma "coisa material do mundo" do qual temos "conhecimento perceptivo" como também uma entidade meramente mental ou imaginária "da natureza de um signo ou pensamento" (Noth 2003).

Por fim, Noth (2003) também utiliza a citação de Peirce para definição de interpretante do signo: “Um signo dirigi-se a alguém, isto é, cria na mente dessa pessoa um signo equivalente, ou talvez, um signo mais desenvolvido. Chamo o signo assim criado o interpretante do primeiro signo".

"Há três, e não mais do que três, elementos formais e universais em todos os fenômenos que se apresentam à percepção da mente. Num nível de generalização máxima, esses elementos foram chamados de primeiridade, secundidade e terceiridade. A primeiridade aparece em tudo o que estiver relacionado com acaso, possibilidade, qualidade, sentimento, originalidade, liberdade, mônada. A secundidade está ligada às ideais de dependência, determinação, dualidade, ação e reação, aqui e agora, conflito, surpresa, dúvida. A terceiridade diz respeito à generalidade, continuidade, crescimento, inteligência. A forma mais simples da terceiridade, segundo Peirce, manifesta-se no signo, visto que é um primeiro (algo que se apresenta à mente), ligando um segundo (aquilo que o signo indica, se refere ou represente) a um terceiro (o efeito que o signo irá provocar em um possível intérprete)" (SANTAELLA, 2016, p. 7).

Esta lógica triádica tem grande importância e quando fica clara, auxilia na compreensão do porque a definição de signo por Peirce tem três teorias: significação, objetivação e interpretação. A significação fala da relação do signo consigo mesmo, daquilo que capacita a funcionar como tal tendo relação com 
sua existência concreta, advindo uma teoria das potencialidades e limites da significação. A objetivação determina o que o signo é, podendo ser tomado como contexto genérico como o contexto do signo. A teoria da objetivação estuda questões relacionadas a denotação, à realidade e referência. Por fim, a interpretação vem da relação com o fundamento com o interpretante. $\mathrm{O}$ resultado é uma teoria de interpretação com implicações quanto aos seus efeitos sobre o intérprete (Santaella 2002).

Os estudos de Peirce levam a três elementos formais e universais que serão apresentados a seguir:

\subsection{Primeiridade}

Segundo Caraciola (2015), a primeiridade têm relação com o sensível, sendo um ato comtemplativo de imersão na qualidade. Neste momento o poder de funcionar como signo existe de forma mais suave, ou seja, há apenas uma sugestão dessa potencialidade. O foco está no modo como o fenômeno se apresenta e não em definições ou interpretações. Os signos de primeiridade são chamados de quali-signos. Nos quali-signos o poder da sugestão de uma qualidade acaba possibilitando o funcionando do signo. Santaella (2002) diz que o quali-signo tem relação com cores, formas, texturas, volumes, equilíbrio, luz, sombra, linhas, movimentos, etc.

\subsection{Segundidade}

Segundo Santaella e Noth (1999), o símbolo não possuiria significado algum sem o ícone e não teria poder de referência sem o índice. Para que o símbolo possa ser aplicado a um caso e conecte com o objeto, ele necessita de um índice. Caraciola (2015) diz que "a secundidade relaciona um fenômeno primeiro a um segundo, estando ligada às ideias de força bruta, ação e reação, conflito, resistência, esforço, aqui e agora. $\mathrm{O}$ estado contemplativo se esvai e o fenômeno se apresenta como realidade concreta, na sua natureza de sinsigno, um signo de existência." É a categoria da ação, do fato, da realidade e da experiência no tempo e no espaço: "Ela nos aparece em fatos tais como o outro, a relação, compulsão, efeito, dependência, independência, negação, ocorrência, realidade, resultado." (NÖTH 2003: 64)

\subsection{Terceiridade}

Segundo Ribeiro (2010), mesmo com todo o poder de referência de um símbolo e todo poder indicativo de um índice, ainda é necessária uma significação. Esta é razão da necessidade de um ícone. O ícone junto à terceiridade representam o efeito que o signo provocará em um possível interpretante. Segundo Carciola (2015): "na terceiridade, os fenômenos são interpretados a partir de associações advindas de conhecimento prévio, as 
experiências colaterais. A terceira categoria corresponde à definição de signo genuíno, pois este é capaz de produzir outro signo, o que corresponde ao processo de semiose infinita; sendo assim, a terceiridade é um processo de crescimento contínuo.

\section{Campanha Gatorade Wins}

As duas peças da campanha impressa "Gatorade Always Wins!" foram veiculadas no ano de 2010, produzidas pela agência DDB, de Dubai, na categoria bebidas não alcoólicas. Obviamente por se trataram de anúncios de uma mesma campanha de uma única marca, apresentam elementos comuns, como a assinatura da marca (logotipo) acrescido do slogan, por exemplo. Embora não sejam propriamente o objeto desta análise, os autores consideram importante salientar algumas peculiaridades dos dois elementos supracitados.

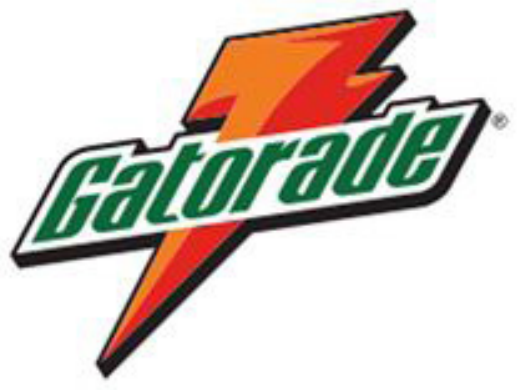

Figura 01: Logo Gatorade

Fonte: Wikipedia

O primeiro deles é o nome "Gatorade", que na verdade é uma contração (PEREZ, 2016) de outras duas palavras: Gators ${ }^{1}$ e Limonade $^{2}$. Ainda com base em Perez, 2016 é possível classificar o nome como patronímico, por fazer alusão aos seus criadores/donos, e ao também como toponímicos, já que na cultura estadunidense, onde nasceu a marca, o animal Aligátor e o próprio nome dos "donos" gators, tem ligação com a geografia e o estado em questão, a Flórida.Já em sua oconstituição visual, apresenta uma fonte classificada como humanista, com peso entre bold e black, largura condensada e postura oblíqua. A linha visual da palavra está em um eixo levemente inclinado, apontando para cima. Tanto a postura da própria fonte quanto a inclinação do eixo geral, denotam características de movimento e subida, que condizem o posicionamento da marca e estão relacionados ao esporte.

Outro elemento que merece ser salientado é o raio laranja estilizado (PEREZ, 2016) ao fundo dos elementos.Do ponto de vista mitológico, tem

\footnotetext{
${ }^{1}$ Apelido do time de futebol americano Florida Gators. Relativo a Aligátores.

2 Limonada, em tradução livre pelos autores.
} 
ligação com vários deuses, como por exemplo Zeus na cultura grega e Júpiter, seu equivalente na cultura romana, além de Thor na mitologia nórdica e Seth na egípcia. $O$ raio também é um ícone que representa a energia elétrica. Além disso é um elemento muito presente na cultura pop, como em Harry Potter, David Bowie, The Flash, Shazam, Adão Negro e o corredor Usain Bolt, garoto propaganda da Gatorade, inclusive.

Sendo assim, fica evidente a relação da construção marcária com o globo de atuação da marca. É impossível não relacionar os deuses gregos, como Zeus às competições olímpicas, que surgiram para encontrar os humanos mais próximos do Olímpo, daí o nome, inclusive. Além disso, a representação da energia elétrica faz alusão a própria energia do corpo humano, que é necessária à prática esportiva e promessa do próprio produto, "reabastecer" a reserva de energia gasta.

E por falar em "reabastecer", há ainda o slogan da marcacomo elemento comum. "Rehydrate, Replanish, Refuel" ${ }^{3}$ ou faz uso da figura de linguagem pleonasmo, por apresentar termos com significados basicamente iguais, e da figura de metáfora, já que Refuel tem sua tradução ligada a combustível de máquinas e automóveis. Sendo assim, é notável o progresso de sentido para formar o entendimento de que o produto atua como água, enche novamente o corpo com os sais perdidos pelo suor, e reabastece o corpo com energia, para tornar o atleta "uma máquina" além de estabelecer a analogia de que se a gasolina, álcool e diesel são combustíveis das maquinas automotores como os carros e caminhões, o Gatorade é então o combustível da "máquina corpo humano".

\section{Análise 1 - Peça Maratona}

A primeira peça analisada da campanha (ver figura 02 abaixo) é a relacionada com 'Running' e maratona. A análise tem início do ponto de vista qualitativo-icônico buscando capturar as impressões de uma primeira observação. Neste primeiro momento, a referência em relação aos elementos formais está na Primeiridade. Não há intenção de uma análise indicativa, muito menos interpretativa. Em primeira instância, podemos já identificar diversos elementos como uma variedade de cores, com alto teor de contraste entre o azul do líquido de Gatorade e marrom alaranjado da pista de atletismo. Podemos identificar os números em cada uma das pistas abaixo das garrafas como também os números $42.195 \mathrm{~m}$ e 2:06:28 no canto direito inferior. Abaixo do display com os números, grama verde e acima dela, a continuidade da pista.

\footnotetext{
3 "Reidratar, encher novamente, reabastecer" em tradução livre feita pelos autores.
} 


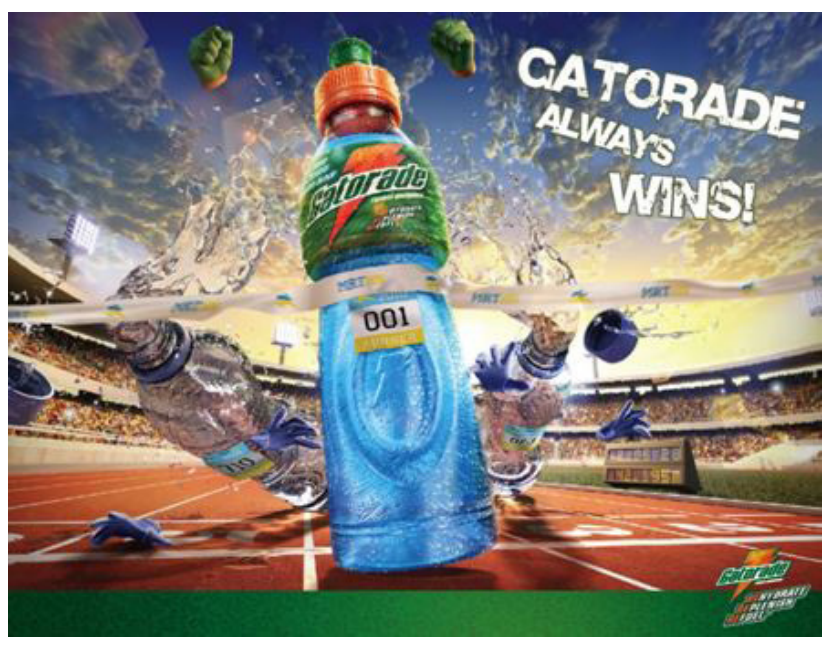

Figura 02: Anúncio maratona

Fonte: Agência DDBDubai

Há ainda holofotes com muita luz branca ao fundo, junto a arquibancadas com espectadores. No céu, parcialmente nublado, há um indicativo de que há pouca presença do sol, possivelmente se tratando de um entardecer.No foco da peça, há duas garrafas plásticas semelhantes entre si, com mesmo formato, cores, com mesmo conteúdo líquido transparente e com seu conteúdo derramando junto a queda de suas tampas. Há uma terceira garrafa com formato diferente e com líquido azul com rótulo da marca Gatorade, em posição ereta e com sua aparência quase que intacta. Podemos perceber ao redor da garrafa que há respingos de líquido transparente, e todas as três garrafas possuem um número de identificação sendo da garrafa de Gatorade o número 001 e das outras garrafas idênticas os números 710 e 073 . Em ambas as identificações, também encontrados o número 2010. A frente das garrafas está uma faixa branca, com as letras MRTHN.

Não menos importante, cada uma das três garrafas na peça possui um par de "mãos" que por mais que estejam suspensas no ar, estão dispostas circundando cada uma das garrafas.

No canto superior direito encontramos o slogan da campanha "Gatorade Always wins!" e no canto inferior direito o logotipo da marca Gatorade na época de 2010 junto a três palavras que são o slogan da marca na época "Rehydrate, Replenish, Refuel".

A próxima etapa de avaliação tem relação com a indicialidade e a indicação à partir da primeira análise contemplativa. Após as primeiras impressões qualitativas, a análise parte do ponto de vista singular-indicativo. 


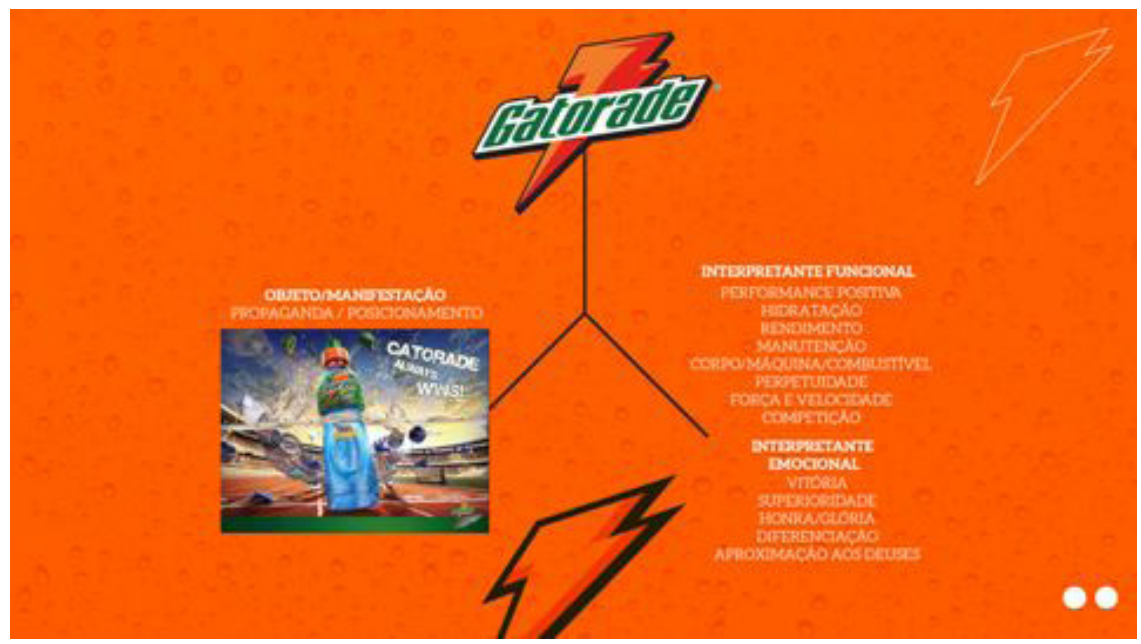

Figura 03: Tríade semiótica do anúncio

Fonte: Elaboração dos autores

Podemos identificar que a peça como um todo reflete uma competição de maratona à partir dos elementos expostos: estádio com pista de corrida, display com números referentes a distância total de uma prova de maratona. As garrafas são dotadas de características antropomórficas como as mãos suspensas, representando as próprias mãos humanas, as tampas sendo uma referência a cabeça de um atleta, as tarjas numéricas (típicas em uma competição de corrida para identificação dos atletas), os espectadores acompanhando a chegada da corrida.

A faixa a frente dos corredores corresponde a linha de chegada de uma prova, com o indicativo MRTHN, abreviação de 'Marathon'. Na tarja dos atletas ainda há a identificação de Runner (corredor) e 2010 (ano da prova e que a campanha foi veiculada).

As garrafas tombando fazem indicação a garrafas de água, mais genéricas e semelhantes entre si. O líquido transparente auxilia nesta indicação e ambas as garrafas de água estão também sem suas tampas, não podendo reter o líquido dentro de seus recipientes. Ao redor da garrafa de Gatorade, podemos encontrar uma grande quantidade de gotículas de líquido, que fazem referência ao suor e podemos perceber que a garrafa de Gatorade se encontra "de pé", ou seja, em uma condição diferente das garrafas de água.

A garrafa de Gatorade é a única cruzando a linha de chegada, indicando que é a garrafa que ganhou a competição.

Por fim, chegamos a etapa de análise convencional-simbólico. Após a primeira etapa qualitativa e icônica e a segunda etapa singular e indicativa a última etapa da análise tem teor interpretativo. 
Podemos inicialmente já perceber a principal mensagem da campanha em que há vitória do isotônico Gatorade sobre a água. As formas antropomorfizadas tornam as garrafas em uma simbologia de atletas de maratona. As garrafas representam atletas competindo em uma maratona. A garrafa de Gatorade representa os atletas que ingerem Gatorade em contrapartida aos competidores "garrafas de água". Assim, o atleta que consome o isotônico são vitoriosos em suas competições quando comparados a água. O slogan"Gatorade Always Wins!" reforça a mensagem de que o Gatorade sempre ganha, independente da circunstância.

A vitória não simplesmente marginal pela representação de como as garrafas de água estão ao fim da prova. Ambas as garrafas estão tombando e seu líquido se esvaindo representa que eles não conseguem reter e realizar a manutenção necessária em seu corpo para garantir uma boa performance neste tipo de competição. As tampas também estão fora das garrafas, o que pode ser uma representação de que os atletas também podem "perder a cabeça" se não estiverem em plenas condições físicas para completar a competição, ou seja, relacionando com a capacidade dos atletas se manterem equilibrados e hidratados em toda a competição

A garrafa de Gatorade pelo contrário encontra-se ereta e com seu conteúdo inteiramente dentro da garrafa. Seus "punhos" estão cerrados e levantados, fazendo uma indicação de vitória e/ou conquista enquanto os punhos das garrafas de água estão se preparando para o impacto com o solo.

O competidor da Gatorade também está em cima da pista 4, sendo a pista (junto a pista 5) as pistas destinadas a aqueles que possuem melhores marcas em prévias a competição final, sendo então a pista com melhor rendimento. O número 001 do Gatorade, referenciando ao número do competidor está diretamente relacionado a posição em relação aos concorrentes pois as duas garrafas de água possuem números "aleatórios" quando comparado ao significado do número 1.

O tempo da prova de 2:06:28 é menor que o recorde olímpico da maratona, ou seja, mostrando que de fato está relacionado com o número 1 não somente na posição da prova como também na história do esporte.

\section{Análise 2 - Peça Boxe}

A segunda peça analisada (ver figura 04 logo abaixo) é relativa ao boxe. Ao contemplar é perceptível a vermelhidão e as outras cores, como amarelo, azul, verde, laranja e preto, bem como elementos da liquidez do conteúdo das garrafas, que são de plástico bem como a lona (base do ringue), delimitado por cordas elásticas. Outro líquido presente são as gotas do processo de condensação na parte externas das garrafas, que na condição de representar seres humanos, são gotas suor. Os fachos de luz, tanto de spot quanto de difusão, produzidos 
por lâmpadas sustentadas por estruturas metálicas, além de flashes e sombras. Há ainda uma suave névoa e a presença do raio da marca Gatorade.

Quanto a segundidade ou distinção, temos a existência de um ringue de boxe, para a realização de uma luta do gênero, com iluminação de vários refletores. Os espectadores são vultos não identificáveis. As garrafas são antropomorfizadas, isto é, são representações humanas. Uma delas, a de água genérica (sem marcas ou qualquer outra referência que a diferencie), está caída, sem a tampa, que se encontra no chão, e com praticamente todo o seu conteúdo derramado pelo ringue. A outra, a de Gatorade está de pé, completamente cheia de um líquido amarelo vívido, com rótulo e formato da garrafa também atuante como elemento diferenciador.

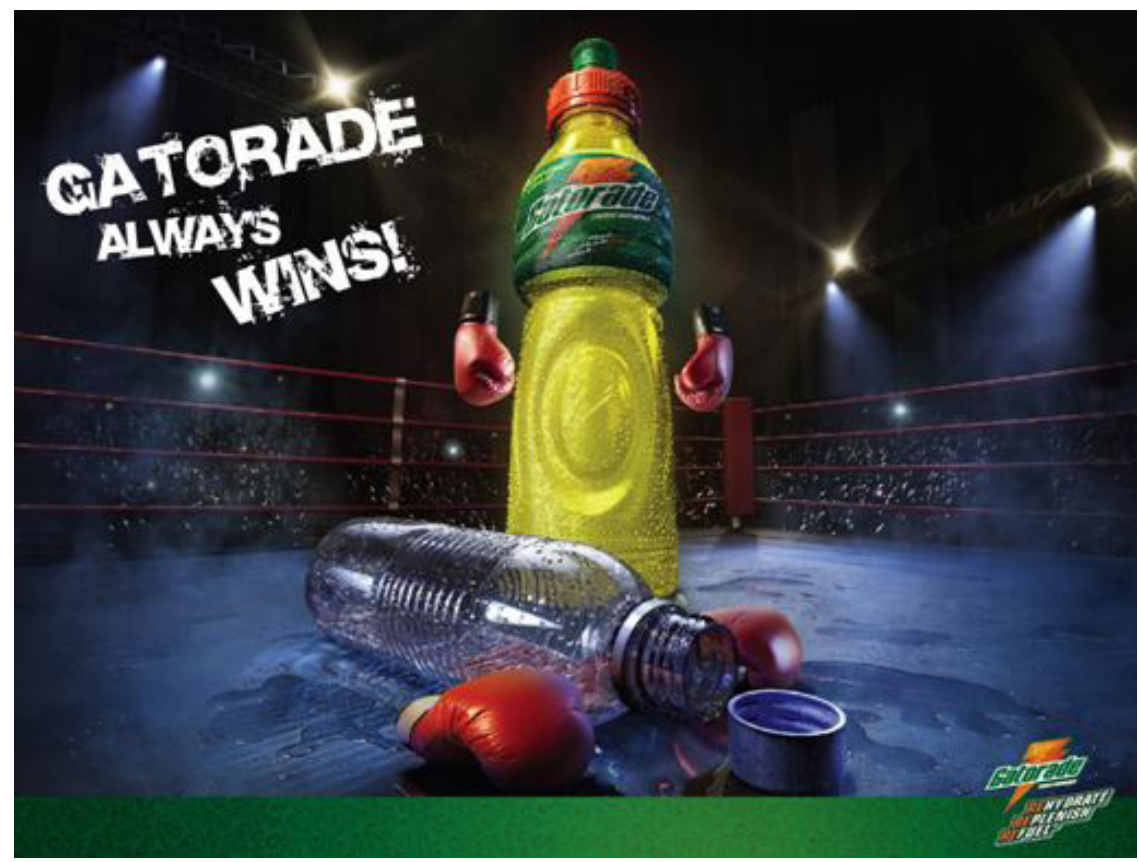

\section{Figura 04: Anúncio boxe}

Fonte: Agência DDB-Dubai

O amarelo do líquido do Gatorade destoa dos tons mais sombrios presentes no resto da peça, sendo importante não somente como ponto de destaque na peça como também em relação ao espectro de cores, em que a cor amarela está ao centro no espectro eletromagnético em relação ao comprimento de onda. A garrafa de Gatorade representando um lutador também se mostra intacta, sem quaisquer avarias, mostrando a superioridade do Gatorade frente ao competidor. A fumaça presente em todo o ringue transforma-se em praticamente um áurea ao redor da garrafa de Gatorade. 
O líquido ao redor da garrafa de Gatorade sempre o suor de um atleta que mesmo com o esforço intenso em uma performance de alto rendimento não causa qualquer diminuição do conteúdo líquido do isotônico, mostrando o quanto ele pode manter o corpo hidratadosobre estas condições. Podemos ainda dizer que a tampa ao chão pode representar as avarias causadas pela performance do isotônico frente a água, que não pode manter a hidratação do competidor, e assim, gerou queda na performance. As lutas para baixo do isotônico representam a guarda baixa, o que denota que o competidor não está mais sob ameaça.

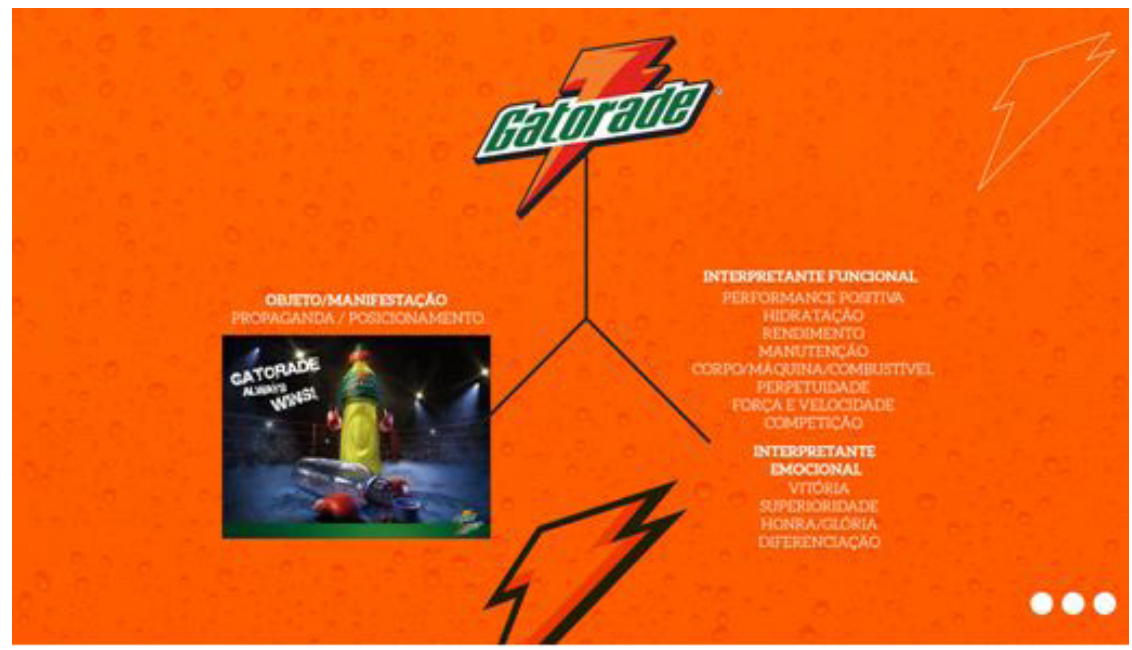

\section{Figura 05: Tríade semiótica do anúncio 2}

Fonte: Agência DDB-Dubai

Vitória do isotônico em relação a água. A própria escrita de "Gatorade always wins" é uma hipérbole que faz referência a vitória em qualquer situação frente a outros produtos relacionados a hidratação corpórea. No caso específico, a utilização de antropomorfização das garrafas leva a um contexto de uma luta de boxe em que o isotônico se sai vitorioso frente a água. A garrafa de agua inclusive está caída com todo seu conteúdo líquido na lona do ringue, o que pode representar que o isotônico é capaz de reter o líquido em seu corpo até o fim da luta em contrapartida da garrafa de água. O líquido no chão também faz alusão ao sangue derramado, comumente visto em lutas de boxe, em que o oponente, quando golpeado, acaba tendo feridas que sagram.

O fato da garrafa estar ao chão tem relação com o momento máximo do Boxe, o nocaute. Este tipo de situação acontece quando um dos lutadores neutraliza e finaliza com o oponente a ponto em que ele não possui mais condições de continuar a luta. A luta então é interrompida com vitória para 
aquele que se manteve de pé. As cordas vermelhas, representam o perímetro do ringue, delimitando a ação onde a luta deve acontecer e podemos perceber que a garrafa de isotônico está ao centro dela, também fazendo relação de que ele não estava pressionado pelo lutador representado pela garrafa de água, ou seja, próximo as cordas. Podemos perceber que as luzes tanto fazem parte dos holofotes sempre presentes em um estádio onde uma luta de boxe acontece como também podendo ser flash de câmeras dos espectadores, que lotam o estádio, mostrando que a luta possuía um grande quórum.

\section{Considerações finais}

Ambas as peças analisadas da campanha "Nome da Campanha" condizem com as informações transmitidas pela marca e posicionamento do produto na área de performance esportiva. O universo da campanha se dá em palcos da área, pista olímpica e um ringue. Sendo assim, têm potencial comunicativo de reforçar na mente do consumidor os ideais da marca, como o de aproximação com atletas de alto nível. pela similaridade. Esta é manifestada por meio do fator comum entre um atleta com índices olímpicos e alguém que pratica atividades após o expediente pode ser o consumo do produto, como se a justificativa de que, se funciona para o atleta, pode funcionar para o usuário comum, fosse um dos reforçadores de compra/uso.

Aos estudos futuros, caberá a análise de peças da marca Gatorade após a reformulação de sua marca para verificar se o potencial comunicativo desejável ainda se mantém. Além da óbvia contribuição à academia com o engrossamento do caldo dos trabalhos científicos com semiótica aplicada, há o diálogo com o mercado da publicidade, para contribuir com a tomada de decisão de gestores empresariais e profissionais de criação e/ou planejamento em agências que tenham trabalhos na mesma linha do objeto desta análise.

Por meio da análise semiótica foi possível perceber uma série de outros conceitos que cantam em sintonia com as peças. O primeiro deles é a ritualidade da práxis esportiva, que se manifesta quanto é analisado o contexto social das atividades dos anúncios, a corrida e a luta. Elementos como a repetição concentração e catarse são comuns aos esportes e rituais religiosos, além da incorporação de detalhes próprios de religiões, como os aspectos mitológicos mencionados anteriormente, como o raio e os jogos olímpicos, por exemplo.

Um outro ponto interdisciplinar manifesta-se ao refletir sobre a essência humana, que segundo Darwin (2010) é competir e reproduzir, sendo reforçado posteriormente por Dawkins (2007), que apresenta a própria existência como uma competição. É possível então, entendo as peças da campanha como estruturadas a partir de uma abordagem psicanalítica (Perez 2016) elucubrar a partir do princípio da transferência de Freud e da psicanálise que existe uma transferência do desejo reprodutivo (acrescido de valor hedônico) à própria 
competição esportiva, ou seja, o homo sapiens como ser desejante e sexual, que compete por natureza para reproduzir e vê os genes mais fortes "serem selecionados" para avançar no tempo, pela própria natureza, têm nas provas esportivas o valor sexual implícito de competir e selecionar os mais fortes e melhores. Talvez essa seja uma das explicações possíveis para a obsessão publicitária, que foi dominante por muito tempo, pelo uso de corpos atléticos, palavra derivada de atleta, que por sua vez tem em sua etimologia ligações profundas com a competição pública e busca por prêmios.

\section{Referências}

AUMONT, Jacques. 2011.A imagem. São Paulo: Ed. Papirus.

BACHA, M.2005. Semiótica Aplicada ao Marketing: a Marca Como Signo. Enanpad.

CARACIOLA, Carolina. 2015.Semiótica Aplicada: Análise de uma Peça Publicitária da Marca de Luxo Louis Vuitton sob o Espectro da Teoria Peircena. Intercom - Sociedade Brasileira de Estudos Interdisciplinares da Comunicação. XXXVIII Congresso Brasileiro de Ciências da Comunicação - Rio de Janeiro, RJ.

DARWIN, C. 2010. A origem das espécies. São Paulo: Folha de São Paulo.

DAWKINS, R. 2007.O gene egoísta. São Paulo: Companhia das Letras.

NÖTH, Winfried. 2003.Panorama da semiótica: de Platão a Peirce. São Paulo: Annablume.

PEIRCE, Charles S. Semiótica. 2010. São Paulo: Ed. Perspectiva.

PEREZ, C. Gestão e Semiótica da Marca: a Publicidade como Construção e Sustentação Signica. 2007. Intercom - Sociedade Brasileira de Estudos Interdisciplinares da Comunicação. XXX Congresso Brasileiro de Ciências da Comunicação - Rio de Janeiro, RJ.

2016. Signos da Marca:expressividade e sensorialidade. São Paulo: Cengage Learning.

RIBEIRO, Emílio Soares. 2010. Um estudo sobre o símbolo, com base na semiótica de Peirce. Estudos Semióticos, [s.I.], v. 6, n. 1, p.46-53. Universidade de Sao Paulo Sistema Integrado de Bibliotecas - SIBiUSP. http://dx.doi. org/10.11606/issn.1980-4016.esse.2010.49258. (acesso em 23 de janeiro de 2019)

SANTAELLA, Lúcia. 2002.Semiótica aplicada. São Paulo: Ed. Thomson. 
; NÖTH, Winfried. 2010.Estratégias semióticas da publicidade. São Paulo: Cengage Learning.

2012. Semiótica aplicada. São Paulo: Pioneira Thomson Learning. 2016.Semiótica aplicada. São Paulo: Cengage Learning. 


\section{RECURRENCIAS Y NOVEDADES EN ESPACIOS DE LA PUBLICIDAD}





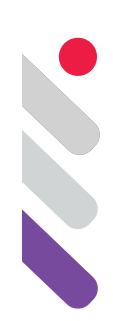

\title{
Trajectories and meanings in specialty coffee packaging: a semiotic exploration of the Brazilian market.
}

DOI: 10.24308/IASS-2019-5-019

\author{
Maria Collier de Mendonça \\ Federal Universityof Santa Catarina, Brazil \\ mariacmendonca@gmail.com \\ Flavia Cardoso \\ Universidad Adolfo Ibáñez, Chile \\ flavia.cardoso@uai.cl \\ Richard Perassi \\ Federal University of Santa Catarina, Brazil \\ richard.perassi@uol.com.br
}

\section{Introduction}

Brands deliver meaningful benefits to consumers such as perceptions of quality, brand experiences, symbolic relationships and senses of identity (Oswald 2012) through tangible and material branding elements: logos, packaging, ads, etc. that express, communicate and visualize the brand (Wheeler 2008). Similarly, for Bourdieu (1984) aesthetics are central to the sense of distinction that consumers experience because it indicates and symbolizes objectively and subjectively aesthetic stances that consumer goods help position their users within social spaces (Bourdieu 1984).

Packaging is particularly relevant to consumer experiences as it encourages consumers to discover brands and products at the point-of-sale, materializing brand identities and communicating product attributes and benefits, thus translating aesthetic and symbolic-cultural meanings that contribute to the construction of meanings, consequently helping consumers to engage in a more interactive experience. In fact, "consumers shop for meanings, not stuff" (Oswald 2012:1).

Considering the relevance of packaging for consumers, this manuscript explores the different layers of meanings that specialty coffee packaging communicates to consumers. We apply Peircean semiotic concepts to investigate 
this question. Semiotics studies meanings of words, images, languages and communication processes in nature and in culture and is widely used in diverse fields such as Marketing and Design.

Consumers interact with signs in constant transformation.As Danesi (2006: 3-5) highlights, the trajectory from a product-commodity to a brand has a semiotic nature, because brands have strong emotional appeal, based on meaningful associations intertwined with their identity. Furthermore,brands acquire new meanings when interacting with consumers in dynamic ways, being particularly reinforced by the current ubiquitous communicationenvironment (Danesi 2006).For this reason, semiotics has been used to explore communication and consumption phenomena in recent decades.

In this context, Niemeyer (2010) emphasizes that semiotics helps us to understand the meaning of packaging, which, in addition to being aesthetically attractive or functional, must communicate qualities and characteristics of the methods of production and usage purposes to consumers. According to this author, each product communicates messages from users to themselves and from users to others, but also diffuses the aesthetic, symbolic and cultural values of the contexts with which it interacts (Niemeyer 2010). For that reason, we investigate how different visual and verbal signs participate in the construction of specialty coffee packaging design in the Brazilian market.

First, we define the segment of specialty coffee based on previous works by Quintão, Brito and Belk (2017). Next, we present the theoretical-methodological approach used. We argue that packaging design plays a relevant role in specialty coffee consumption as it is the branding element that materializes the desired distinction (Bourdieu 1984) anchoring the consumer experience.

\section{Literature review}

Food consumption is central to human relationships (Counihan and Van Esterik 2012) and society has enforced rules about what represents a 'good' or a 'bad' food and 'right' or 'wrong' eating behavior since antiquity (Askegaard et al. 2014; Johnson, Thomas and Grier 2017). In fact, a large body of research has looked at food consumption from different perspectives and epistemological positions. For example, Lévi-Strauss (1990) set out to create a universal system of meanings in the language of foods, while Mary Douglas (1972) aimed at deciphering the social codes of meals and for Bourdieu (1984), food expresses and defines class relations.

Coffee, in particular, has been extensively studied in relation to consumer culture. For instance, Thompson and Arsel (2004) have looked at the hegemonic influence that Starbucks exercises upon local coffee shops by imposing its servicescape (Bitner 1999) while an anti-Starbucks discourse simultaneously circulates in popular culture. Moreover, Karababa and Ger (2011) demonstrate 
that, in the context of the early Ottoman coffee shop, consumers and marketers challenged the authority of the state and religion, to discuss the implications of the centrality of transgressive hedonism in this process.

More recently, Pomiès (2016), investigates how professional coffee preparation contests influence baristas' practices during championships first, and then baristas' mundane practices in coffee shops. She sustains that a normative discourse emerges from these contests and eventually shapes baristas' mundane practice whether they participate to the championship or not. Moreover, Quintão et al. (2016) explain how amateur consumers relate with baristas and with the public during their consumption practices. Similarly, Quintão et al. (2017) addresses the role played by ritual in connoisseurship consumption and consumers' taste in the context of high-end coffee shopsand theorizes the process that converts regular consumers into connoisseur consumers by establishing and reinforcing differences between mass and connoisseurship consumption.

However, despite the relevant contributions provided by these studies to our understanding of coffee consumption meanings, understanding the role of servicescapes (Bitner 1999) and brand advertising has been prioritized, while the role of packaging has been only tangentially explored. Consequently, we propose to close this gap by using applied semiotic research to bridge the existing knowledge from the Design and Consumer Culture Theory literatures.

\section{Methodology}

This section includes three topics. First, we introduce the analytical framework. Second, we briefly describe the context of the coffee category, and specialty segment in Brazil. Finally, we detailfieldwork procedures. It is worth mentioning this paper is focused on the sharing of preliminary results of an ongoingresearch project, to be continued inupcoming publications.

\subsection{Analytical framework}

The semiotic analysis is based on Peircean theory, which understands the sign as a triadic relationship.

A sign, or representamen, is something which stands to somebody for something in some respect or capacity. It addresses somebody, that is, creates in the mind of that person an equivalent sign, or perhaps a more developed sign. That sign which it creates I call the interpretant of the first sign. The sign stands for something, its object. It stands for that object, not in all respects, but in reference to a sort of idea, which I have sometimes called the ground of the representamen. (CP, 2.228 apud Bergman and Paavola 2013) 
According to Santaella (2004: 69), when analyzing a design product from a semiotic perspective, we aim at understanding the communicative potential of a product. In this sense, semiotic analysis explores what effects a product may produce while interacting with a consumer.

Instead of analyzing one specific sign or product package, in this manuscript we have conducted a semiotic mapping of specialty coffee packaging to understand frequent visual and verbal signs communicated by this segment in Brazil.

The analytical stepsexplore three semiotic points of view, previously described by Santaella (2004): (1) qualitative-iconic, (2) singular-indexical, and (3) conventional-symbolic.

(1) The qualitative-iconic point of view explores firstimpressions evoked by the sign, its visible and abstract qualities. For instance: free associations are iconic, hypothetical and uncontrollable. Spontaneous and comparative relations among similarities between sign and object are also iconic. These impressions and associations include material qualities, such as colors, shapes, textures, volumes, and abstract qualities (simplicity, sophistication, among others).

(2) The singular-indexical point of view considers that the existing sign belongs to a specific context in space and time. Thus, it investigates its origin and identity aspects, methods of production, usage purposes, but is also includes how the sign interacts with its target audience.

(3) The conventional-symbolic point of view involves sociocultural values and symbolic meanings associated with the sign, such as myths and archetypes connected to its message, and especially how symbolic aspects are culturally building the brand identity.

\subsection{The specialty coffee segment in Brazil}

According to studies recently published by the Brazilian Coffee Industry Association (ABIC), the global coffee market has been growing steadily since the 1990s. Brazilian coffee production represents $35 \%$ of world production, and Brazil is the world's largest coffee exporter. Additionally, the average Brazilian consumes approximately 839 cups of coffee per year, thus, Brazil has the secondlargest per capita consumption of coffee in the world (ABIC apud FIA, 2019).

According to $A B I C, 95 \%$ of the Brazilian population consumes this beverage at home or in coffee shops. The traditional segment (mass market) leads the market with 90 to $95 \%$ of domestic consumption, but the premium segment is growing and conquering a demanding customer niche that values high quality, controlled origin, sustainable production, and new methods of preparation. Some premium consumers appreciate the consumption of the beverage in coffee shops, while others usually buy specialty coffee at retailers, in supermarkets, or online (SEBRAE-SC, 2019). 


\subsection{Fieldwork procedures}

The research fieldwork took place from March to July 2019. We visited coffee shops and supermarkets in São Paulo and Florianopolis to observe how coffee packaging is displayed at the points-of-sale. During the fieldwork, we perceived relevant differences among coffee packaging in coffee shops in comparison to supermarkets. Coffee shops were offering premium products, reinforcing artisanal, organic, and fair-trade trends. While supermarkets were selling a wide range of products: from mass market to premium segments, including different value propositions and packaging types (instant, pillow bags, stand up pouch, vacuum-packed, capsules).

Since both data published by ABIC (2019) and fieldwork notes indicated that the premium segment was expanding from the coffee shop niche to the mass market sales channels-with particular emphasis in supermarkets-the authors focused the semiotic analysis on specialty brands sold in supermarkets.

It is worth mentioning that ground and dark roasted coffee lead the domestic market. Oftentimes, traditional coffee is sold in conventional pillow or vacuum packs to the mass market. On the other hand, specialty coffee offers a more diverse product range, including different types of packaging (capsules, vacuum, one-way valve packs) and roasts (light, medium and dark).

The table below (table 1) sums up the most relevant features of the coffee segments, which we have explored in Brazil:

\begin{tabular}{|c|c|c|}
\hline $\begin{array}{l}\text { Mass market } \\
\text { (industrialized + } \\
\text { supermarkets) }\end{array}$ & $\begin{array}{c}\text { Specialty coffee } \\
\text { (industrialized + } \\
\text { supermarkets) }\end{array}$ & $\begin{array}{c}\text { Specialty coffee } \\
\text { (artisanal + coffee shops) }\end{array}$ \\
\hline 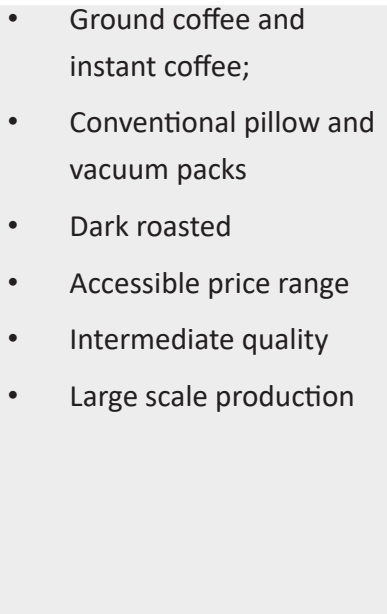 & 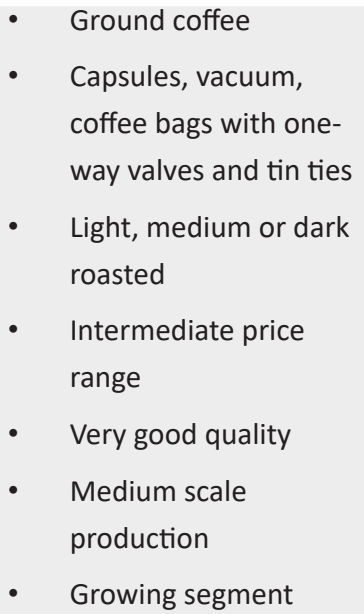 & $\begin{array}{l}\text { - } \quad \text { Ground coffee or beans } \\
\text { - } \quad \text { waffee bags with one- } \\
\text { - } \quad \text { Light, medium or dark } \\
\text { roasted } \\
\text { - } \quad \text { Premium price range } \\
\text { - } \quad \text { Excellent quality } \\
\text { - Small scale production } \\
\text { - } \quad \text { Niche but growing } \\
\text { segment }\end{array}$ \\
\hline
\end{tabular}

Table 1 - Coffee Segments in the Brazilian Market

Source: prepared by the authors, 2019 


\section{Preliminary findings}

At the supermarkets, several coffee brands are displayed side by side on the shelves. Their most relevant codes are clearly communicated by each segment (see figures 1, 2 and 3).

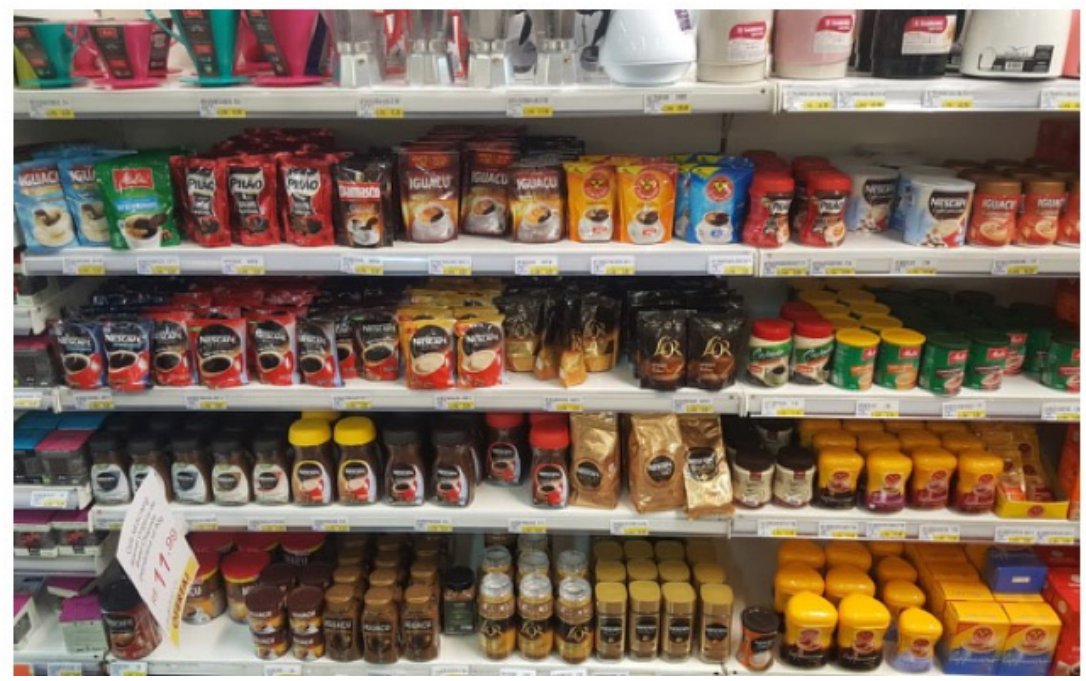

Figure 1 - Photographic record: instant coffee

Source: prepared by the authors, 2019

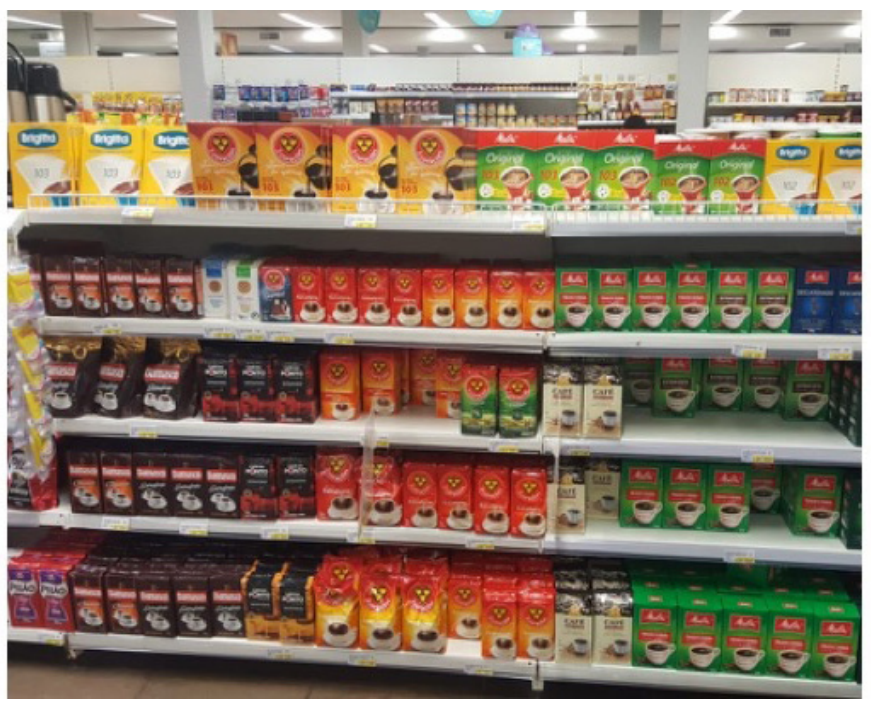

Figure 2 -

Photographic record: mass market coffee Source: prepared by the authors, 2019 

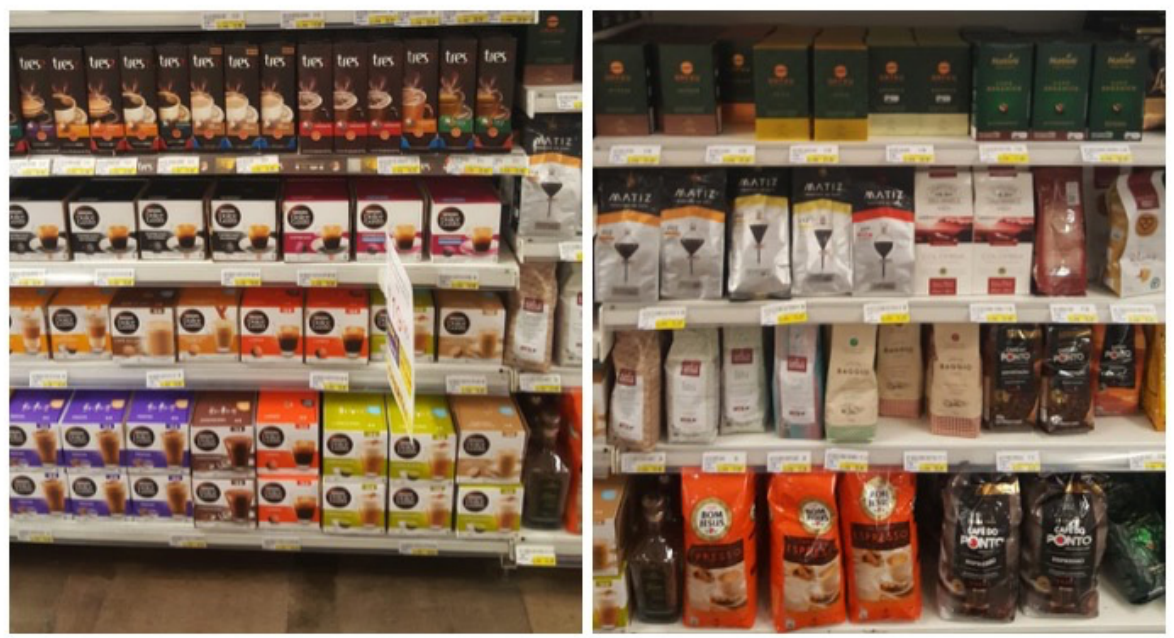

Figure 3 - Photographic record: capsule and specialty coffee Source: prepared by the authors, 2019

\subsection{Mass market packaging signs}

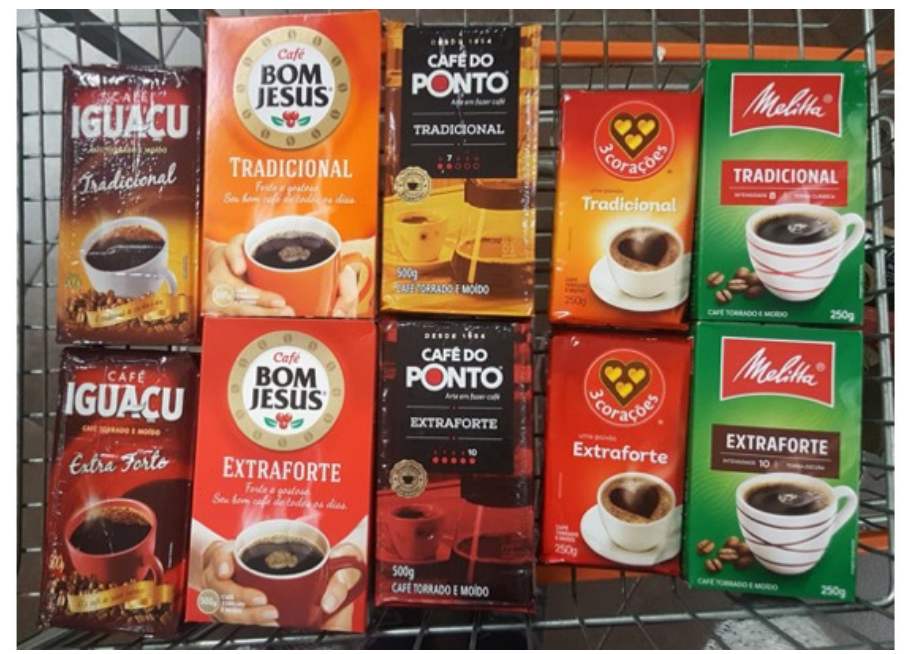

Figure 4 -

Photographic record: mass market coffee Source: prepared by the authors, 2019

Vibrant colors such as red, orange and yellow gradientspredominant in traditional, mass market coffee packaging. Visual composition frequently has two main volumes: the brand logo and a cup of coffee. Some decorative elements, such as coffee beans and shapes imitating the steam movements are recurrent, as well as bolder fonts, and big brand names inside geometric shapes.

Visual codes convey warm feelings, for instance, sunshine effects with sunrise warm tones in the background; or green backgrounds, such as in theMelitta pack which imitates a coffee plantation texture. The appetite appeal 
is conveyed by the representations of the dark cup with steam rising, also suggesting attractive flavor and aroma.The visual messages powerfully express the packaging contains coffee. They emphasizedidactic aspects and functional uses of the product. Consequently, there is a clear indication of the pack content.

Despite the impact of dominant codes in this segment, there is low differentiation among players. Most of them use bold typefaces, vivid colors, coffee cups, traditional or extra strong versions and discount offers.

"3 Corações. Uma paixão Tradicional. Leve $500 \mathrm{~g}$ e pague $475 \mathrm{~g}$ ". [3 Corações. A Traditional passion. Buy 500g and pay 475g.]

"Pilão. O café forte do Brasil". [Pilão. The strong coffee from Brazil].

"3 Corações Extra Forte. Seu café forte".[3 CoraçõesExtra Strong. Your strong coffee].

Most mass market coffee is sold in pillow or vacuum packs, indicating intermediate quality both inside and outside the pack. Thus, product content and packaging material both reflect the same level of quality and suggest affordable prices.

Brand names such as Brasileiro, Pelé and 3 Coraçõeshighlight Brazilian origin, the dark color of the beverage, and the habit of drinking coffee on a daily basis, as illustrated by the Bom Jesus brand tagline: "Forte e gostoso. Seu bom café de todos os dias". [Strong andtasty. Your good coffee everyday].

As previously mentioned, drinking

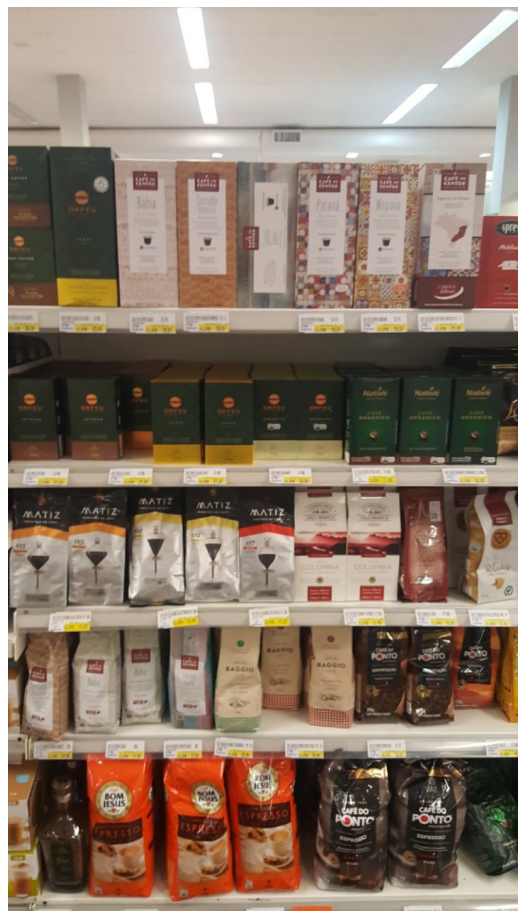
coffee is a strong tradition in Brazil, as is soccer. Therefore, a mass aesthetic taste is reflected in the design standards which, although not refined, are impactful. In this way, packs stand out on shelves, are easily identified and familiar, leading to quick and automatic purchasing.

Consequently, packaging in this segment communicates didactic messages to a massive audience. In other words, this segment offers a good cost benefit for Brazilians who enjoy hot, black and freshly brewed coffee.

Figure 5 - Photographic record: specialty coffee

Source: prepared by the authors, 2018 


\subsection{Specialty coffee packaging signs}

Visual compositionssuggest sophistication, refinement, and distinction in the specialty coffee packs, by using neutral colors and/ or distinctive textures and patterns. Unlike mass market coffee packs, there a diversity of graphic elements, including textures, patterns, gold ornaments, and delicate illustrations imitating handmade drawings among premium packs.This set of visual codes suggest high quality and superior taste.

Logos are subtle and contemporary in design. Nothing is too bold or flashy. Most players have clean, and sophisticated packaging design. However, there is a richness and diversity of visual and verbal signs across brands. For instance, regionalism is indicated by maps, figures, illustrations, textures and written messages. So, these packs clearly inform shoppers that they contain premiumcoffee from the best regions of Brazil, as well as, suggesting a pleasurable consumption experience.

Details on origin, region, elevation, flavor notes, roast, cultivation, producer, certification and preparation are described, combining visual and verbal elements. Graphic elements and ornaments highlight information hierarchies (e.g. color tags for each region). In addition, material aspects of the packaging indicate higher quality, with one-way valves to smell the product.

Undoubtedly, a more sophisticated didacticism is employed, and highlighted by quality seals (ABIC, Organic, Rainforest, ISO), certainly valued by a refined target audience who believe it is worth paying more for high quality coffee.

The names of product lines-Gourmet Especial deOrigem, Rituais, RegiõesBrasileiras[Gourmet Special of Origin, Rituals, Brazilian Regions] - and brand taglines also communicate relevant differentiation.Café do Centrois presented as a true trip through Brazil's coffee regional history and culture; while3 CoraçõesRituais invites customers todiscover emotions that will make ordinary things memorable.

Consequently, specialty coffee pack design encourages consumers to discover what they are buying, its origin, cultivation, type of bean, roasting, and method of preparation. As a result, thoughtful reading is often required, but welcomed by customers who seek for high differentiation and sophisticated aesthetic standards.

\section{Final remarks}

Packaging narratives refer to the singularities of the product lines, particularities of the farming regions or cultural origins to add value to specialty coffee brands.Different visual elements express gourmetization throughout distinct and diverse development of visual and written codes. 
According to Oswald (2015: 51), while the word gourmet is the most associated with premium beverage and food, luxury prevails for premium fashion and design categories. We agree with her that coffee brands connect the gourmetizing codes, by borrowing signs from gastronomy and gourmet consumer culture. As Oswald (2015) clarifies:

Gourmet consumer culture emphasizes connoisseurship, expertise, and food quality. Gourmet culture is steeped in European gastronomy. It is a masculine domain, as illustrated in the dominance of men tasting, sniffing, and measuring ingredients in the cultural data. The value proposition is based upon the connoisseurship and ranking of the producer, as measured by diplomas, rankings, badges of quality, and taste tests. (Oswald, 2015: 51-52)

However, some Brazilian brands of specialty coffee go beyond regionalism or gourmetizing trends, because they are also linking to Brazilian arts and crafts, and coffee culture. In this way, they add innovation to cultural traditions and symbols, such as the packaging of Café do Centro's gourmet line.

While at the high-end independent coffee shops studied by Quintão, Brito and Belk (2017) and Pomiès (2016), the customer experiences a sense of belonging to a community of experts that is a key cultural-symbolic sign; at the supermarkets, it is the packaging signs that stand out to communicate a rich set of visual and verbal signs. As Perez (2004) emphasizes, the meanings of packaging are revealed at the first time that consumers get in touch with a brand, especially in supermarkets. We agree with Perez (2004) that packaging works as powerful semiotic media because they communicate impactful and relevant messages about brands. Thus, they do not only transport, protect or identify product content, because they also inform branding content materializing brand identity.

In this manuscript, we applied Semiotics to explore visual and verbal signs of coffee packaging in Brazil to bridge existing knowledge in the Design and Consumer Culture Theory literatures. We begin by referring to Consumer Culture Theory (CCT) previous studies on specialty coffee and high-end independent coffee shops,connected with consumer cultural habitsand rituals related to the premium coffee consumption.

The Design literature contributes to our analysis because itis focused on the physical-tangible dimensions of brands to inform and express brands as graphic signs, such as product packs. Thus, fordesigners, brands especially regard what consumers see and touch. Finally, from the Semiotic perspective, what matters is the meaning-making processes, in other words, how products or services become meaningful brands for consumers. In this sense, a semiotic mapping can be an insightful route to explore a specific scenario, such as specialty coffee in Brazilian supermarkets. 
In the upcoming steps of this research, we intend to discuss how muchgourmetizingis worth for consumers, and how this trend is transforming customers' experience in the supermarket conducting a qualitative fieldwork.

\section{Acknowledgements}

This study was financed in part by the Coordenação de Aperfeiçoamento de Pessoal de Nível Superior - Brasil (CAPES) - Finance Code 001.

\section{References}

ASKEGAARD, Soren, ORDABAYEVA, Nailya, CHANDON, Pierre, CHEUNG, Tracy, CHYTKOVA, Zuzana, CORNIL, Yann, CORUS, Canan, EDELL BRITTON, Julie, MATHRAS, Daniele Fay, JUNGHANS, Astrid, BROGAARD KRISTENSEN, Dorthe, MIKKONEN, Ilona, MILLER, Elizabeth G., SAYARH, Nada \& WERLE Carolina. 2014. Moralities in food and health research. Journal of Marketing Management 30(17-18), 1800-1832.

BERGMAN, Mats and PAAVOLA, Sami (eds.). 2013. Representamen'. The Commens Dictionary: Peirce's Terms in His Own Words. New Edition. http:// www.commens.org/dictionary/entry/quote-signs-r-4 (accessed: 7 March 2020).

BOURDIER, Pierre. 1984. Distinction: A social critique of the judgement of taste. Cambridge: Harvard University Press.

COUNIHAN, Carole \& VAN ESTERIK, Penny. (Eds.). 2012. Food and culture: $A$ reader. New York: Routledge.

DANESI, Marcel. 2016. Brands. New York: Routledge.

DOUGLAS, Mary. 1972. Deciphering a meal. Daedalus 101 (1), 61-81.

Estudo traz o panorama do mercado de cafés e cafeterias no Brasil (2019). (accessed: 5 March 2020).

JOHNSON, Guillaume, THOMAS Kevin D. \& GRIER Sonya A. 2017. When the burger becomes halal: a critical discourse analysis of privilege and marketplace inclusion, Consumption Markets \& Culture 20 (6), 497-522. DOI: 10.1080/10253866.2017.1323741(accessed 5 March 2020).

KARABABA, Eminegül, \& GER, Güliz. 2011. Early Modern Ottoman Coffeehouse Culture and the Formation of the Consumer Subject. Journal of Consumer Research 37(5), 737-760. DOI:10.1086/656422 (accessed: 5 March 2020).

LÉVI-STRAUSS, Claude. 1990. Mythologiques (Vol. 4). Chicago: University of Chicago Press. 
Mercado Mundial do Café: Consumo, Produção e Preço (2019). https://fia.com. br/blog/mercado-mundial-do-cafe/ (accessed: 5 March 2020).

NIEMEYER, Lucy. 2010. Elementos de semiótica aplicados ao design. Rio de Janeiro: $2 A B$.

OSWALD, Laura. 2015. Creating Value. The theory and practice of marketing semiotics research. New York: Oxford University Press.

2012. Marketing Semiotics. Signs, Strategies, and Brand Value. New York: Oxford University Press.

PEREZ, Clotilde. 2004. Signos da marca: expressividade e sensorialidade. São Paulo: Thomson.

POMIÈS, Anissa. 2015. Le rôle de l'expertisedansl'élaboration d'un régime de goût et danslaperformationdesmarchés. Une ethnographie des concours de café. Paris: École doctorale de Management Panthéon-Sorbonne, Ph.D. dissertation.

QUINTÃO, Ronan Torres, BRITO, Eliane Pereira Zamith, \& BELK, Russell W. 2017. Connoisseurship Consumption Community and Its Dynamics.Review of Business Management 19(63), 48-64. DOI:10.7819/rbgn.v0i0.2982 (accessed : 5March 2020).

QUINTÃO, Ronan Torres, BRITO, Eliane Pereira Zamith\& BELK, Russell W. 2017. The taste transformation ritual in the specialty coffee market. RAE Revista de Administração de Empresas, 57(5),483-494 http://dx.doi.org/10.1590/s0034759020170506 (accessed 5 March 2020).

SANTAELLA, Lucia. 2004. Semiótica aplicada. São Paulo: Thomson.

THOMPSON, Craig T., ARSEL, Zeynep. 2004. The Starbucks Brandscape and Consumers' (Anticorporate) Experiences of Glocalization. Journal of Consumer Research31(3), 631-642. DOI:10.1086/425098 (accessed 5 March 2020).

WHEELER, Alina. 2008. Design de identidade da marca.Porto Alegre: Bookman. 


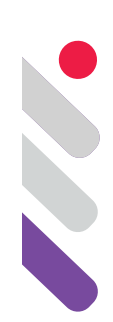

\title{
Estrategias, transacciones y símbolos en la publicidad electoral audiovisual
}

DOI: 10.24308/IASS-2019-5-020

\author{
María Ernestina Morales \\ Universidad Nacional de Misiones, Argentina \\ ernestinamora@hotmail.com
}

\subsection{Introducción}

Este trabajo es parte de un posgrado doctoral y proyecto de investigación (UNaM); donde planteamos recorrer una diversidad discursiva, géneros y formatos de la comunicación política. Con eje en materialidades significantes (Verón) de una campaña electoral. Si bien hemos abordado, exclusivamente discursos de la campaña,también queremos compartir otro aspecto de la comunicación política que resulta interesante para el discurso electoral:la comunicación políticadegobierno.

Los procesos de comunicaciónpolítica se danen una interacción comunicativa humana y massmediada. En esta última, sus producciones en diferentes campos políticosofrecen un complejo semiótico-comunicativo donde se cruzan relaciones, mediaciones y acción de los signos. Esta trama significativa despliega y re-actualiza conocimientos, memoria eimaginación. Desde el plano de lo político, estos procesos semióticosactúan en la conciencia política de los ciudadanos en tanto actores sociales; en el espacio público de la vida política/democrática que es laarena de lucha de los signos: debates, opiniones, adhesiones, oposiciones, etc. Pero en nuestro ejemplo, hay una producción de relato que ofrece más una acción a corto plazo, que un pensamiento crítico o debate alguno.

Desde una perspectiva semiótica abordamos el discurso político publicitario en formatoaudiovisual en búsqueda de una interpretación desde el campo político; partiendo de la hipótesis de que las productos audiovisuales de la comunicación política, de gobierno o electoral, los spots con/tienen desfases o pasajes que proponen cambios de roles en los actores intervinientes, formas de interpretación y acción política. 
Toda esta riqueza semiótica implica mediaciones complejas, a partir de la especificidad de sus materiales, sus formas y objetivos.Se trata deir al encuentro de huellas parareconstruirpequeños fragmentos del eslabón de dicha cadena semiótica. Identificadas materialmente con sus operaciones discursivas en tanto portadoras de sentidos, desde "el reconocimiento del reconocimiento" (Verón, 2013: 405). A partir del relatoque crea la comunicación política de gobiernovemos su dimensión constitutiva, temática-composicional- estilística, su diseño arquitectónico y composición orquestal (M. Bajtín).

\subsection{Materialidades de sentidos para apuntar}

Teniendo en cuenta que la comunicación humana como atributo del hombre, se basa principalmente en su capacidad de memoria y posibilidad de semiosis. De allí, que cualquier comunicación humana supone una mediación bajo alguna forma o evento material que se diferencie de la fuente y del destino (Verón, 2013: 144); incluye también la comunicación política, que nos llega a través de los sentidos, y "resulta de la materialidad sensorial, inevitable, del soporte" (ídem 145). Afirma Verón que cuando los signos cobran "autonomía" de la fuente, del destino y además persisten en el tiempo, es decir no se evanescen; estamos ante un "fenómeno mediático" (ídem). Así es como se nos presenta una campaña de comunicación política, sea electoral o de gestión. En cuanto a la mediatización,Verón señala como una "secuencia de fenómenos mediáticos históricos que resultan de determinadas materialización de la semiosis, obtenidas por procedimientos técnicos." (Ídem, 147).

En término de lo que nos interesa, cabe señalar a los dispositivosde comunicación, como diferentes de los medios de comunicación, por cuanto este último designa a "los usos que se estabilizaron a lo largo de la historia" (Verón, 2013: 144). Pues bien, las materialidades de sentidos que median entre los ciudadanos y los estrategas de las campañas y circulan a partir de las estrategias de propagandas y publicidades políticas.

\subsection{Hablando de comunicación política}

Al hablar de comunicación política, nos interesa focalizar qué perfil tiene la comunicación de gobierno, en este campo. Para J.L. Andreni,en la C.P.se distinguen dos áreas: la Comunicación Política Electoral y la Comunicación Política Gubernamental, que es posterior a la campaña específicamente durante toda la gestión de gobierno" (Vega, 2003:138). Esta última, más allá de informar sobre la gestión propiamente, es la construcción misma del poder, que se da en la fase de gobierno, y es un aspecto arquitectónico de "ejercicio de poder e implementación de una agenda" (Noguera, 2003:79); y los actores políticos hacen campaña, desde antes de los tiempo formales electorales. Para la comunicación política de gobierno, los objetivos son parte de un vasto campo 
que se torna difícil unificar porque cada uno integra a su vez, políticas públicas, urgencias, contingencias e intereses diversos. Armar estrategias de campañas a largo o corto plazo, son lasposibilidades más eficaces. Respecto del mensaje, o contenido para nosotros, Noguera señala que, en la comunicación política de gobierno"se deben combinar distintos mensajes en cada etapa, $<\ldots>$ y área de gobierno, y procurar que todos ellos estén relacionados entre sí y generen un discurso unificado" (Noguera, 2003:88). Otro factor importante es el ciclo temporal, que es más largo porque la "tarea es más exigente aún, porque se vota todos los días y cada uno de los días" (Noguera, 2003: 90).

Asimismo, creemos que hay límites difusos entre la comunicación política de gobierno y comunicación política electoral, que nos ocupa. Éstos potencian las virtudes persuasivas a partir del discursivo publicitario propio del marketing político; y el juego que propone el uso de las emociones como protagonista del contenido. Al comunicar a la ciudadanía, las estrategias discursivas son pensadas en términos de dos temporalidades: la electoral y la de gestión o acción de gobierno.Lo que nos ocupa aquí es la temporalidad de la acción política donde hallamos huellas de las condiciones de reconocimiento y donde inferimos está su mayor generación de inferencias y sentidos.

El formato audiovisual genera una serie de pasajes de la mediatización -en la comunicación política- hacia:de los medios tradicionales al imperio de las redes sociales -el prosumidor ${ }^{1}$ - que atravesamos hoy con la netpolítica ${ }^{2}$; la necesidad del gobierno de contar/mostrar lo que se hace; a un modelo de comunicación política de estilo propagandista-marquetinera (G. Achache 2012); de reemplazo de los tres destinatarios ${ }^{3}$ de Verón, a un sujeto/target de una estrategia comercial.

Parafraseando a Rincón, el formato audiovisual nos plantea una manera de relación con el mundo de la vida, que por lógica incluye lo político; son "nuevos laboratorios experimentales de la sensibilidad" (Rincón, 2002:11), del pensamiento y reflexión de lo político. Una posibilidad de narrar el mundo inmediato a la vez que desplegar el poder. Parte del encanto audiovisual en la comunicación política.

Esta comunicación de gobierno mediatizadaconfirma a Verón (2012): una lucha por el control de los sentidos en detrimento de la construcción

\footnotetext{
${ }^{1}$ Término actual del marketing político y que resume la idea de un sujeto/ciudadano que es productor y consumidor.

2 Pierre Musso, retoma la distinción de Umberto Eco, "paleo" y "neotelevision" y lo señala como netpolítica: "entendida como una política expresiva, basada en la relación directa y emocional con el votante-consumidor". Musso, P. (2012) El fenómeno Berlusconi: ni populismo ni videocracia, sino neopoltica; En: La comunicación política, Buenos Aires, Ed. La Crujía, pp 133.

${ }^{3}$ Cuando el enunciador político construye sus destinatarios "positivos" y "negativos" con quienes entra en relación. Verón los identifica como contradestinatario, prodestinatario y paradestinatario. Verón, E., La palabra adversativa. Observaciones sobre la enunciación política, En: EL Discurso Político. Lenguajes y acontecimientos, Buenos Aires, Ed. Hachette, 198715.17
} 
de lazos colectivos a largo plazo. Es en este intersticio donde lo audiovisual, suma a lo simbólico el orden de lo icónico e indicial(Verón, 2012:183) como atributos por donde se cuelan sentidos arraigados en la memoria, emociones, identidades ylo axiomático. Una lucha en la arena, que da ventaja a la lógica unidimensionalacortoplazo (Verón, 2012).

\subsection{Otra entrada posible}

En la comunicación política los discursos configuran tanto estilos de gobierno, de comunicación de acción política, como así tambiénaspiraactuar sobre opiniones y conductas de los ciudadanos en torno al gobierno y sus produccionescomunicativas. Otro perfil conceptual aporta Virginia Beaudouxpara quien la comunicación política de gobierno es un,

Mensaje con intencionalidad directa o indirecta política, totalmente controlado por el emisor en sus fases de producción y difusión, cuyo objetivo es la promoción deliberada de las ideas e intereses de comunicador, con el propósito de producir en el público seleccionado ciertas respuestascognitivas, afectivas y/o comportamentales acordes (Beaudoux y otros, 2011: 28). [Énfasis mío]

Actualmente, al estar encampaña permanente, la delgada línea divisoria entre campaña y gobierno, se materializa en la comunicación gubernamental. Para ello, actores de gobiernoy consultores/productorestrabajan en "sofisticadas campañas propagandísticas $<. . .>$ para enmarcar la cobertura que realizan de los actos de gobierno". (Beaudoux y otros, 2011: 167) para un proceso de influencia deliberada que un gobierno intenta realizar sobre la opinión pública, $<\ldots .>$ con el objetivo de volver más eficiente la gestión política (Ídem, 168)

\section{5. ¿Propagar? ¿Publicitar? ¿Cuál es la cuestión?}

La propaganda política, si bien es vista como un tipo de comunicación política, cuyo lenguaje particular es político, tiene varios abordajes conceptuales y desde diferentes disciplinas sociales. Nos alcanza con citar puntos en común con la publicidad; y delimitar su principal característica, como sentidos que circulan en ciertas condiciones históricas; en el marco de los sistemas democráticos liberales, y como parte del sistema social y político.

El lugar que ocupa tanto la propaganda como la publicidad de la gestión de gobierno, dicen algo sobre los cambios; lo que hacen; o producen los ciudadanos con los fenómenos mediáticos de los estrategas del marketing político. De hecho, es enérgico el poder de la producción y circulación de todo aquello que hace a la vida política de una nación. Con énfasis en los momentos de producción, circulación o reconocimiento, según sucedan estilos e ideologías políticas. Dicho de otra manera, la propaganda y publicidad políticaconforman 
una modalidad de comunicación necesaria para los sistemas políticos.

La propaganda/publicidad política, hermana y potencia a las campañas y a la comunicación de gestión gubernamental. La misma profesionalización de la política, hace que una gestión, deba publicitarse como principal estrategia sobre la que luego se montará la campaña. Así se trate de un continuum político que se aferra al poder, o sucesores de un mismo grupo.

Qué implica pensar la política para comunicar? a)Circular como un "mensaje con intencionalidad directa o indirectamente política" (D'Adamo y otros, 2011: 28). Bajo el control absoluto de;b) la producción y difusión, en manos del enunciador -estratega/grupo político/funcionarios públicos-. Cuyo objetivo es,c) "la promoción deliberada de las ideas e intereses" (Ídem) de dicho enunciador. A lo que se agrega, d) "el propósito de producir" (Ídem) en el ciudadano o público -previamente identificado al detalle con gustos y preferencias que van desde colores hasta imaginarios sociales, e) "ciertas respuestas cognitivas, afectivas y/ comportamentales" (Ídem). La aprobación de la gestión o el voto. Esta modalidad de comunicación política tiene tres aspectos claves, y que remiten a espacios socios semióticos: la estrategia, la transacción y lo simbólico. En diferentes géneros, soportes discursivos de lo político.

\section{Localizando Materialidades significativas}

Nuestro corpus se conformacon dos spots audiovisual, producidos por el mismo equipo que produce material para la campaña electoral, todos de libre circulación. Para este trabajo, se descargaron directamente del canal de YouTube, Promotora Misiones:

Sorteo de viviendas IPRoDHa ${ }^{4}$ en Oberá duración 1':53" (spot 1); publicado el 07/05/2015 [img.1] captura: https://www.youtube.com/results?search_ query=sorteo+de+viviendas+obera+2015; y

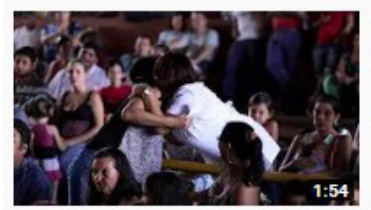

Sorteo de viviendas Iprodha en Oberá

Promotora Misiones $\cdot 203$ vistas $\cdot$ hace 4 años

Participé del soreteo de viviendas para centenares de familias que se hicieron presentes en el Parque de las Naciones. En esta

Img. 1

Una lejanía esperanzadora duración 1':04" (spot 1); publicado el 09/06/2015 [img.2] captura:https://www.youtube.com/results?search_ query=lejania+esperanzadora+2015

${ }^{4}$ Instituto Provincial de Desarrollo Habitacional,ejecuta las políticas públicas de viviendas sociales. 


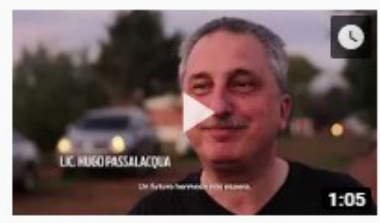

Una lejanía esperanzadora

Promotora Misiones - 146 vistas - hace 4 años

Visita al Barrio Esperanza de Posadas, donde vecinas manifestaron a Hugo Passalacqua sus intenciones de contar con una..

Img. 2

Ambos atienden nuestros Discursos Objetos (DO), de los cuales pretendemos reconocer huellas, desde operaciones de las gramáticas de producción y reconocimiento.

En cuanto al contenido temático de los spots, si bien parten deacciones de gobierno diversas, el posicionamiento que se hace desde las piezas sólo exhibe y destaca la figura delVice Gobernador.Los destinatarios potenciales y para quien fueron pensados, ciudadanos misioneros en del padrón de electores habilitados para votar.

La serie circuló en la provincia de Misiones de manera libre, en los principales medios de transmisión audiovisual, canal de televisión por aire, estatal de la provincia y otros privados de la capital provincial; televisión por cable en el resto de las localidades provinciales; el canal YouTube en internet; redes sociales, Facebook, WhatsApp y sitios oficiales de la campaña. Aclaramos que todas las imágenes de este trabajo son fotogramas capturados de los spot. Uno de los criterios de selección de esta serie, obedece a la manera en que está organizada su puesta en circulación en cuanto a los contenidos temáticos y argumentos de cada uno, su frecuencia -de un mes de diferencia- y estrategia de la campaña.

Otro aspecto es su género publicitario, que muestra ideologemas propios de la propaganda política. No obstante, podríamos decir que es una publicidad social que se circunscribe en el campo político, de información de acción de gobierno, orientados sí, a ganar las elecciones. Por último, como parte de la comunicación gubernamentaly criterio de selección; el contenido temáticode la serie son políticas públicasorientadas a derechos fundamentales como el acceso a la vivienda.

\section{Cuando empieza una campaña? o cuando deberíamos dejar a hacer campaña?}

En el contenido, se imbrican mensajes articulando políticas con áreas específicas de gobierno. Por un lado, el Instituto Provincial de Desarrollo Habitacional cuyo tema/contenido es el sorteo de las asignaciones de vivienda; y el Ministerio de Gobierno<...> que por su parte entrega lotes a re localizados de una zona inundable. Dos soluciones para una misma problemática, un lugar para vivir, para diferentes grupos sociales. En segundo lugar, el eje unificador de 
los spots es el vice Gobernador, su voz e imagen. Un funcionario en gestión que emplea la comunicación gubernamental para su campaña de posicionamiento electoral. Ocupa la agenda pública como el próximo Gobernador, desde la comunicación de la gestión, su gestión frente al Poder Ejecutivo. Lo que está a consideración del ciudadano son políticas públicas y/o decisiones de gobierno realizadas en gestión.

En el spot 1 Sorteo de viviendas IProDHa en Oberá, seinforma sobre gestión, posiciona al candidato y construye poder: el del futuro Gobernador, en su pasaje de Vice a mandatario principal. Spot 1 [Img.3]. Tratándose del Poder Ejecutivo, se omite al mandatario principal, dejando toda la carga simbólica de poder y posicionamiento en la figura del Vice,su nombre y título profesional. En tanto creación narrativa audiovisual, propone una cercanía virtual [spot, imag. 4] que muestran su lado estratégico, táctico, político. La mano que se estrecha en el saludo, la cercanía, también es la mano que da, en este caso la posibilidad de una vivienda. Al decir de Noguera, las nuevas formas de comunicación gubernamental expone "un nuevo clientelismo, modernizado, tecnificado, pero clientelismo al fin" (Noguera, 2003:82).

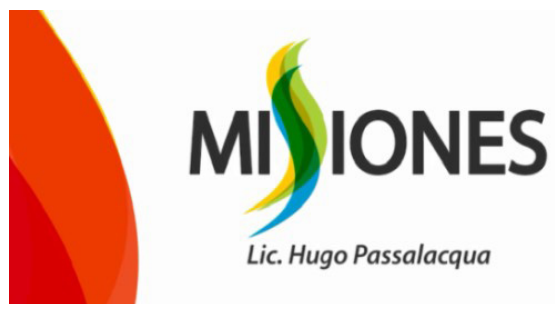

Img. 3

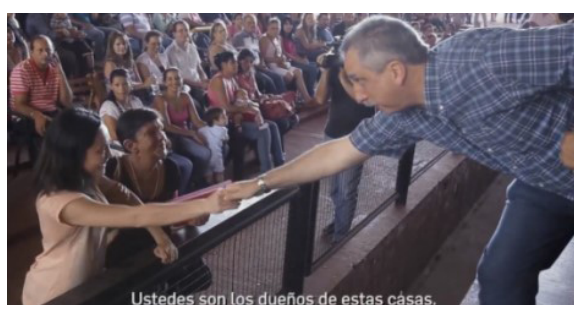

Img. 4

La idea de la campaña permanente siempre está allí con límites difusos. En el spot 2, la voz en off que habla sobre valores e ideales, la esperanza de los ciudadanos y del futuro que los espera, es del propia del Vice/candidato, despojado de su función ejecutiva electiva, en la gráfica del material. Se escucha su voz intercalada con la vecina de un barrio; su rostrohasta cinco veces en fotogramas o secuencias, finaliza con él y una frase clave "un futuro hermoso nos espera" [spot 2, img.5]. A la pregunta, quién representa el futuro para esas y otras familias? La respuesta es indicial.

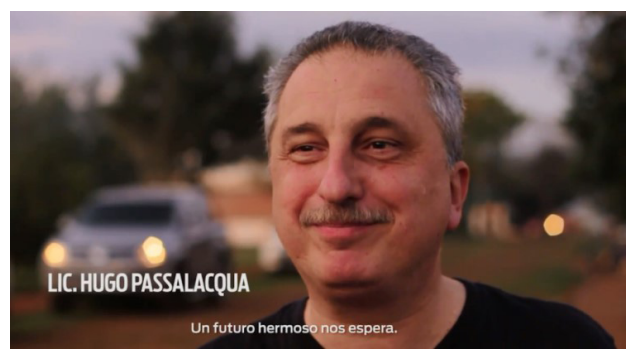

Img. 5 


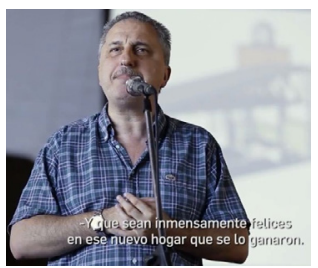

Img. 6

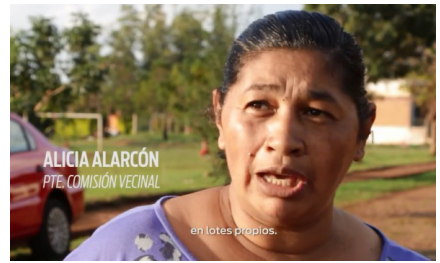

Img. 7

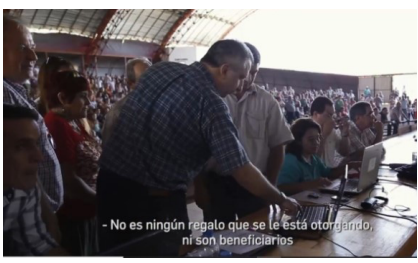

Img. 8

En el posicionamiento del candidato, la estrategia y lógica política del Partido es asegurarla continuidad sin sediciones internas; con frentes comunicativos más segmentados, en este caso como parte de políticas públicas que nuclean a la familia misionera: la vivienda, spot 1, [Img. 6] o la tierra propia, spot2, [Img. 7]

\section{1. Aristas de la comunicación política de gobierno que se repiten en los} spots

a) Proactiva: "iniciativa estratégica para adelantar la agenda de gobierno" (Noguera, 2003:90), [Img. 8 y 9]

b) Comunicación Contable: "asentar en la mente del electorado los logros de la gestión" (Noguera, 2003:90) [Img. 10 y 11]

c) Electoral: "un gobierno viene de una elección y va hacia otra" (Noguera, 2003:90)

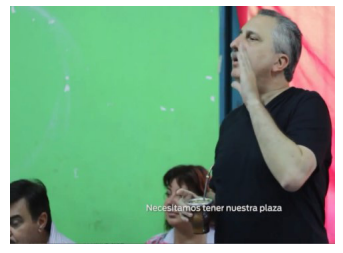

Img. 9

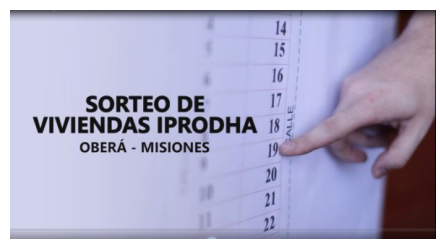

Img. 10

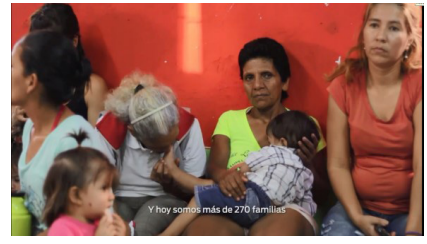

Img. 11

\section{Estrategias, transacciones y lo simbólico}

En esta modalidad de comunicación, hacer público, informar, persuadir, son acciones que demandan una planificación estratégica, para incidir o modificar una acción ciudadana. Por ello, es necesario pensar el contenido-producción y circulación- para generar ciertas respuestas cognitivas, comportamentales y emocionales. Cada una de ellas están relacionadas con los siguientes ejes: a) de estrategia: respuesta cognitiva/comportamental; b) de transacción: ${ }^{5} \mathrm{Cfr}$. O. D’Adamo y otros, en: Propaganda gubernamental. Tácticas e iconografías del poder, $1^{\circ}$ ed., Buenos Aires, La Crujía, 2011. 


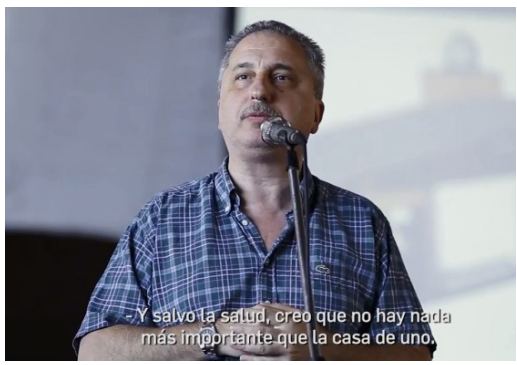

Img. 12

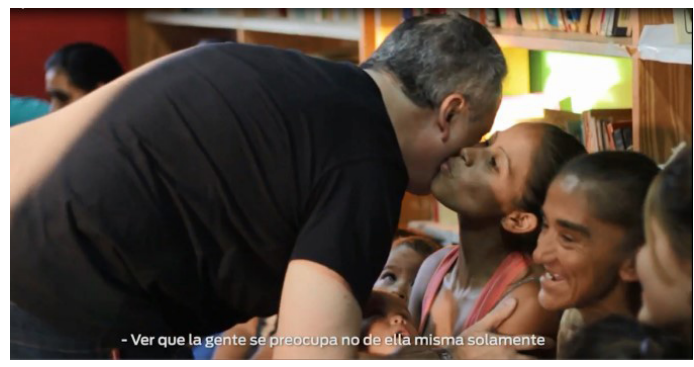

Img.13

surge de los sentidos que generan el contenido/mensaje en los destinatarios y en función de su propia memoria e identidad, que en consecuencia, actuaría según la estrategia. c) lo simbólico: que juega con todos los recursos usados para crear significados y sentidos que estrechan el vínculo entre el gobierno -el Vice Gobernador- y los ciudadanos misioneros. Estos, podemos analizar a partir de estilo del discurso y sus matices dialógicos.

i) La estrategia: si bien la estrategia en ambos spot es movilizar/emocionar con la familia, -la emoción como principal recurso- se perfilan cuatro aristas de la narración audiovisual. El primer lugar es el contenido temático: la familia. Presentada como principio y fin del relato y de las políticas públicas habitacionales. La estrategia es vincular directamente una solución-política pública-acción de gobierno con una necesidad de un núcleo poblacional especifico, un hogar y sus vínculos. El tema, la estrategia, es la familia. En varias las secuencias se repiten en diferentes signos: icono, fotograma icónico de familia[Img. 14]; índice, fotograma indicial de familia [Img. 15]; símbolo, fotograma simbólico de la familia [Img.16]. Con toda la carga emotiva de amorosidad y solidaridad.

Segundo, "el papel activo del otro" (Bajtín): expone acerca de un presente que es diferente, con posibilidad de acceso a la vivienda, cuyo sorteo para asignación, se da en un contexto festivo, familiar y acompañado por el Vice Gobernador. Todos interactuando uno ante el otro y juntos hacia el resto de la ciudadanía en sus propios momentos de reconcomiendo. La interacción discursiva es visualmente vital en los dos spots, cada secuencia o tiene en su

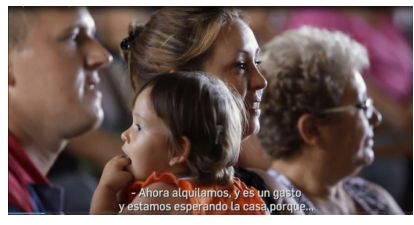

Img. 14

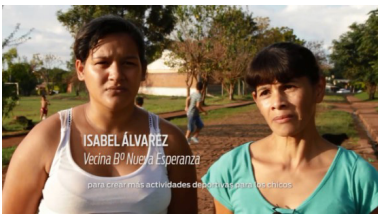

Img. 15

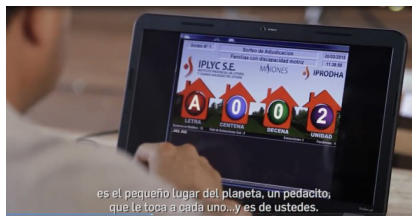

Img. 16 
continuidad, la interacción entre los actores, ciudadanos entre sí y con el Vice Gobernador. La experiencia del acontecimiento es real para esta narrativa, [Img. 17, spot 1].

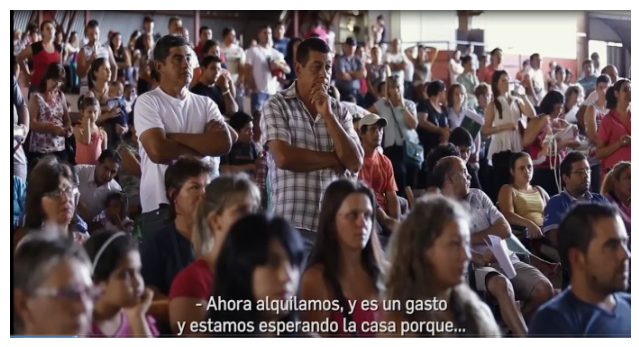

Img. 17

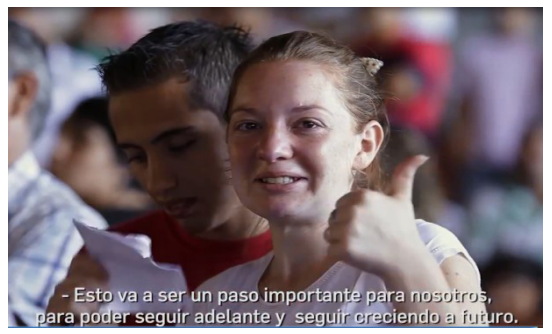

Img. 18

En tercer lugar, la triple orientación del discurso. En el fotograma siguiente [Img. 18, spot 1] vemos una beneficiaria del sorteo de la viviendas, por su gesto inferimos que fue asignada con una vivienda: así lo muestra a la cámara que la registra y su dedo está destinado a quienes la miren. Su mensaje de felicidad es producto de haber recibido la vivienda. Toda su kinésica tiene como finalidad, dar fe del cumplimiento de la gestión del Vice Gobernador, en cuanto a política habitacional.

Por último, vemos dialogo y comprensión de manera completa en los dos spots, entablan un dialogo entre los presentes, entre Gobierno/ciudadano; a los ausentes, a los que viven lejos y esperan una casa, a los demás ciudadanos. La orientación social, es el estilo más fuerte de toda la producción de los audiovisuales: el/los otros y el dialogo como matriz de los relatos [Img.19, spot $1]$.

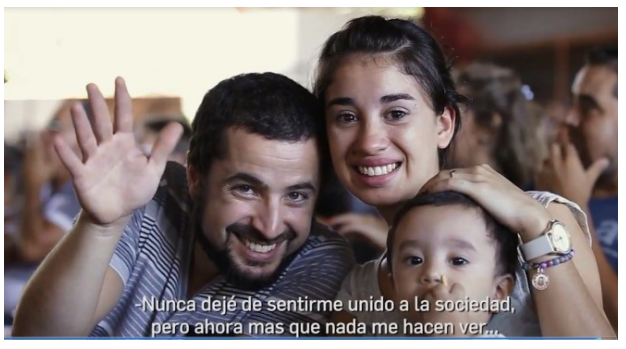

Img. 19
Estas estrategias analizadas desde el catalejo bajtiniano, se repiten en otros formatos y soportes. Cambian los personajes/testimonios/ ciudadanos, y las políticas públicas que se enarbolan como políticas públicas de vanguardia.

ii) Lo transaccional. ¿Qué aspectos representados están construidos de manera tal que puedan ser fácilmente decodificado/resignificado por los ciudadanos? ¿Cómo son comunicados/representados estos aspectos? Y por último, ¿Qué acciones se podrían esperar a partir de ellos? Veamos algunos fotogramas a modo de ejemplo en sus propias esferas comunicativas. 
a) Lo destacado es la identidad misionera, heterogénea que se representan dinámicos recursos sintácticos visuales, p.e. primeros planos de rostros de testimonios y participantes de las reuniones con el Vice Gobernador. Familias jóvenes, modelo tradicional, niños, madres con niños en brazo, niños jugando en la tierra roja. Rostros signados por el paso del tiempo y el trabajo duro. Ropajes sencillos que son acompañados por el Vice. La imagen es fácil de interpretar, reconocer y asumir como propia por parte de cualquier receptor [Img.20 y 21, spot 2].

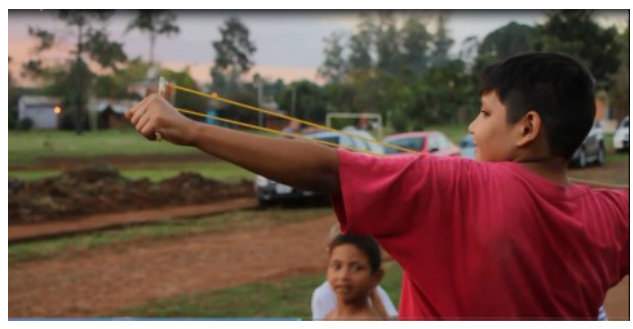

Img. 20

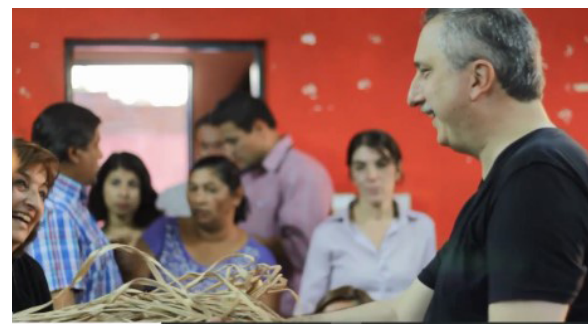

Img. 21

b) La manera de representar y comunicar el eje del relato -la familia- es desde la emoción positiva, la felicidad. El festejo por la vivienda, la alegría por el terreno propio o el barrio con infraestructura para los niños. Es probable que esta algarabía audiovisual, más adelante se transformarán en acompañamientos electoral[Img. 22 y 23 , spot 1$]$.

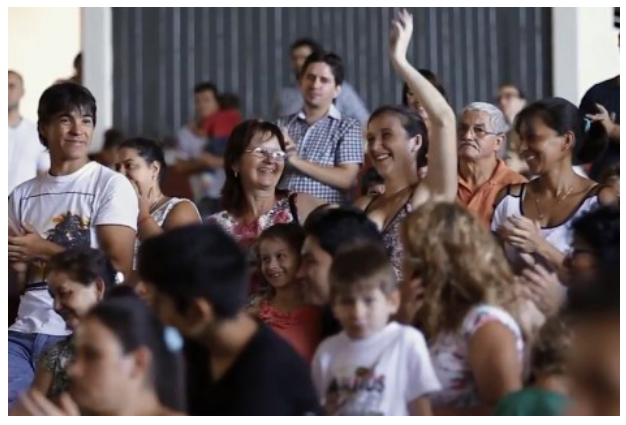

Img. 22

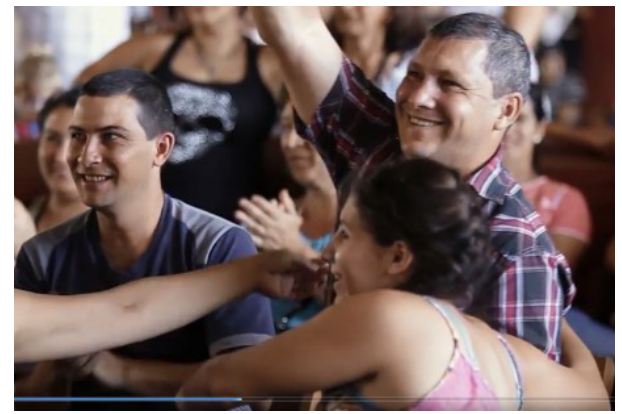

Img. 23

Las transacciones en los spots, desbordan signos arraigados en la identidad misionera y en emociones positivas, acompañados por un Vice/candidato que está cerca y lo declama con su proxemia, kinésica, con una evidente intención de ser un más del montón: inversión de una transacción que se resuelve a corto plazo.

iii) Generación de Significados. Atravesado por los signos, -lo simbólicopone en relieve la idea de familia feliz misionera y su identidad, marcando temáticas recurrentes: la familia, la casa propia, la felicidad. Donde la emociones 
positivas, juegan un rol importante porque "la mente humana se caracteriza por su capacidad para pensar en el futuro, que es su capacidad para relacionar acontecimientos previsibles con los mapas del cerebro" (Castells, 2009:197). Además de la identidad misionera multicultural, se suma el concepto de la inclusión, desde un recurso visual cuidado y de todo sorpresivo emotivo. Quien abre como testimonio, narrando su lugar en el mundo, su manera de encarar la vida, es un beneficiario que también cierra el spot 1 , y su discapacidad motora es lo que atrapa sensiblemente como una política pública inclusiva.

"A pesar de la vida complicada que siempre tengo, siempre estuve pensando, día a día en independizarme" [img 24, spot 1]<...> "nunca dejé de sentirme unido a la sociedad pero ahora más que nunca me hacen ver que uno es uno más" [Img. 25, spot 1]

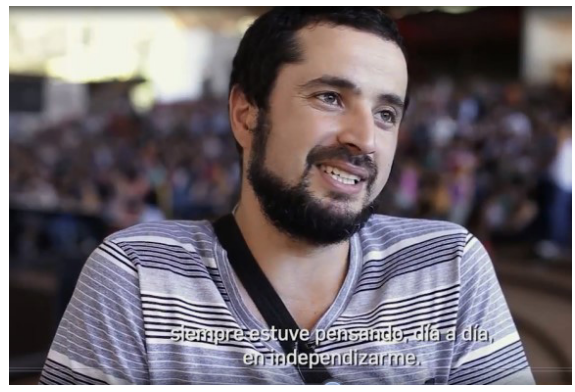

Img. 24

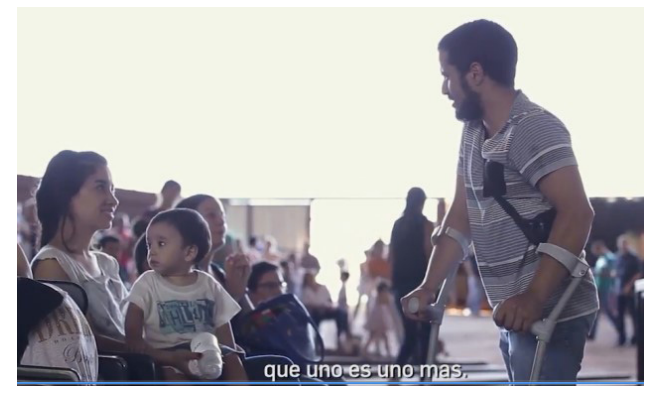

Img. 25

Para que el ciudadano misionero conecte con hechos para la articulación aprobación/voto, debe producirse mediaciones, que se dan en los procesos comunicativos, como vemos en los spots de la CPG analizados. En palabras de Castells, "la mente humana se activa accediendo a los mapas del cerebro mediante el lenguaje" (Castells, 2009: 197). El uso de emociones y sentimientos que surgen a partir de reconocer y compartir los atributos mencionados, darían lugar a la toma de decisión desde lo emotivo, al margen de la racionalidad. Para Castells, los dos casos en que el hombre opina o decide desde lo emotivo, se dan como adhesión o critica, en el campo político.

Con Verón, podemos inferir que esta serie de spot, en tanto signos, cobran autonomía de su fuente y destino y se convierten en una fenómeno mediático, (Verón: 2013, 147) y refuerza/potencia la CPG orientada a la ciudadanía misionera y persuade el voto futuro. A partir de estas materialidades de sentidos que median entre los estrategas de la CPG y los electores misioneros.

\subsection{La matriz dialógica}

Al cierre, destacamos el diseño arquitectónico que se repite en los spot,propios del programa bajtineano. El momento constitutivo de los 
discursos en ambos materiales, tanto en el sorteo de las viviendas sociales, comola reunión con los vecinos del barrio, en ambos casos el protagonismo es del Vice Gobernador/candidato. Los géneros que se destacan van desde una alocución en una acto de gobierno, que tiene como orador al Vice; diálogos minúsculos entre los asistentes que nos llegan en imágenes; testimonios que narran historias de vida; entrevistas periodísticas; fiesta y algarabía que se despliega durante el sorteo de las viviendas sociales. No hay locutores con voz en off, solos los actores: Vice Gobernador que habla a la presentes en instancia de acto de gobierno, y a los otros ciudadanos. Por otro lado, las voces que resuenan de beneficiarios de las políticas públicas que testimonian desde sus propias historias de vida, el antes y el ahora.

En cuanto al dialogismo que se da en el acontecimiento, está atravesado por la performatividad del discurso, en el instante mismo del intercambio de las voces de los enunciadores. El gobierno hace, es la acción misma, en la producción del acto. Por otro lado, la respuestaactiva viene desde los ciudadanos dan fe con sus palabras del acto por la experiencia que manifiestan en el reconocimiento.

En el spot 1 vimos la triple orientación hacia lo aquello a lo que refiere, "y ahora alquilamos, es un gasto y estamos esperando la casa" (mujer con su pareja al lado); lo que se ha dicho, "salvo la salud, creo que no hay nada más importante que la casa de uno" (Vice Gobernador); los sujetos participantes "no es ningún regalo que se les está dando, ni son beneficiarios, ustedes son los dueños de estas casa" (Vice Gobernador).

El acto político es también el espacio de la valoración; en el spot 2 tenemos dos valoraciones por un lado, la menos positiva la enuncian los vecinos del barrio: "Empezó siendo el barrio de unos pocos, de unas 19 familias que eran afectadas por las inundaciones". En contraste con la palabra positiva en la voz del funcionario. Desde el acontecimiento mismo, como hecho, como acción de gobierno que toda la enunciación refuerza con la estética, recursos visuales, música épica, intercambio de voces. En el mismo spot, queda clara la acentuación y valoración que hace el Vice afirma:

\footnotetext{
"ver que la gente se preocupa no de ella solamente, que es legítimo, sino sobre todo de los que vienen más adelante, de los hijos, de los nietos, es una cosa maravillosa, es o le hace ver a uno la provincia con una lejanía esperanzadora con un horizonte muy cristalino, muy blanco, muy hermosos, muy lindo. Un futuro muy hermosos nos espera" (Vice Gobernador).
}

Que además es también un ideologema frente a la cosmovisión que tiene el funcionario público. Desde la ciudadanía, más allá que las voces son únicamente los beneficiarios, ellos representan en tanto signo indicial, a todos los misioneros; que se traduciría como una valoración de apoyo a la gestión.Por último, sin dudas alguna, los recursos visuales y las voces de los ciudadanos, son 
el plato fuerte de la identidad misionera, como símbolo, como índice de lo que el partido político en cuestión llama, el misionerismo.

\section{Referencias bibliográficas}

ARNAUD, Mercier, coord., 2012.La comunicación Política, Buenos Aires:ed, La Crujía,

CASTELLS, Manuel 2009.Comunicación y Poder, trad. María Hernández, Madrid: Alianza Editorial

GARCÍA BEAUDOUX, Virginia 2011. Propaganda gubernamental: tácticas e iconografías del poder, $1^{\circ}$ ed. Buenos Aires: ed. La Crujía

IZURIETA, Roberto y otros 2003. Estrategias de comunicación para gobiernos, $1^{\circ}$ ed. $1^{\circ}$ reimp. Buenos Aires: ed. La Crujía

GARCÍA, Marcelino 2002.Narración. Semiosis/Memoria, $1^{\circ}$ ed. Posadas, Misiones: Editorial Universitaria Universidad Nacional de Misiones

RINCÓN, Omar 2002.Televisión, video y subjetividad, $1^{\circ}$ ed. $1^{\circ}$ impresión 2007, Bogotá: ed. Grupo Editorial Norma

VERÓN, Eliseo 2013.La Semiosis Social 2, ideas, momentos, interpretantes, $1^{\circ}$ ed. Ciudad Autónoma de Buenos Aires: ed. Paidós.

y otros 1987. El discurso Político. Lenguajes y acontecimientos, $1^{\circ}$ ed. Buenos Aires: ed. Hachette

\section{Material de archivo:}

Canal de YouTube Promotora Misiones, en:

https://www.youtube.com/channel/UCNwG-WcrWQUxCwZ_Allktuw

spot 1: https://www.youtube.com/results?search

query $=$ sorteo+de+viviendas+obera +2015

spot 2:https://www.youtube.com/results?search_ query=lejania+esperanzadora+2015 


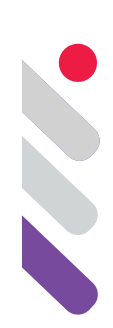

\title{
Racismo y clasismo en la publicidad mexicana
}

DOI: 10.24308/IASS-2019-5-021

\author{
Carl Winston Jones \\ Royal College of Art, London. \\ carlwj1@mac.com
}

\section{Introducción}

El discurso racista y clasista existe en la mayor parte del mundo y particularmente en México. Dentro de la sociedad mexicana hay estrategias que refuerzan las ideologías segregacionistas, clasistas y racistas, y estas medidas opresivas continúan reproduciéndose hasta la fecha a través de varias vías, en específico los medios. Me interesan las funciones y sistemas que permiten que esto se propague, y la forma en que la audiencia reproduce inadvertidamente el significado. Este proyecto arroja nueva luz sobre la profesión de los practicantes y académicos de la publicidad, ya que ésta con frecuencia es vista de manera negativa en los estudios de comunicación. Como plantearon teóricamente Marx y Engels en The Ruling Class and the Ruling Ideas (1970: 9), Fuchs (2005) en Dallas Smythe Today - The Audience Commodity, y Adorno y Horkheimer de la Escuela de Frankfurt (2002) Dialectic of Enlightenment (94-136), la publicidad se considera un arma de las corporaciones que se utiliza para convencer al público de consumir mercancías y también de convertirse en una "audiencia mercancía," como establece Smythe (1977) en Communications: Blind Spot of Western Marxism. Sin embargo, me gustaría demostrar que las herramientas y técnicas publicitarias pueden emplearse a favor del bienestar humano, creando mensajes que contrarresten la comunicación corporativa occidental y estimulen la cultura local. Este objetivo se logrará cuando se publique el presente proyecto de tesis y se informe al público mexicano sobre cómo se construyen y reciben los mensajes, dando al espectador las armas para interpretar y cuestionar el significado subyacente en la comunicación recibida vía los metamedios.

Mi tesis explora las representaciones visuales de las relaciones de poder en la economía política de México según se expresa en la publicidad. 


\subsection{Componente teórico}

Hace quinientos años, la clase gobernante en México clasificaba a sus habitantes en categorías raciales, con los indígenas en el escalón inferior y los españoles en el superior. Después de la colonización española, las razas comenzaron a mezclarse, creando un nuevo grupo de mexicanos llamados mestizos. Esta categorización de los ciudadanos mexicanos se refleja en los mensajes publicitarios producidos dentro de las fronteras nacionales de México, y es financiada por la clase gobernante. La teoría semiótica y la teoría crítica de la raza aplicadas a mi investigación se centran "en el discurso y las imágenes que crean, mantienen y transforman las relaciones culturales de significado y poder como fenómenos raciales" (Lidlof 2011: 63).

Durante mi investigación sobre el tema de la raza en México, descubrí que las categorías raciales han constituido un tema importante en la historia mexicana. Sin embargo, a partir de 1907 el gobierno dejó de clasificar oficialmente a sus ciudadanos con base en la raza; por el contrario, pidió a los mexicanos identificarse (Lizcano 2005) a través del lenguaje, por ejemplo con el uso de las lenguas indígenas.

La idea de que la piel blanca fue un concepto importado a México que llegó con la colonización de los españoles no es cierta, ya que "la preferencia por la piel más clara existía en el mundo antes de la colonización y también entre los aztecas y las culturas árabes ancestrales, como símbolos de la clase social alta y como símbolos de juventud y virginidad" (Hussain 2010: 19).

Un mito muy aceptado sobre un dios blanco se atribuye al momento en que el emperador azteca Moctezuma dio la bienvenida al conquistador español Hernán Cortés en Tenochtitlan, ahora Ciudad de México. Los aztecas creían que el dios Quetzalcóatl volvería como un dios-rey con barba y piel blanca, y Moctezuma creyó que Cortés era Quetzalcóatl, cabalgando "sobre el lomo de animales que parecían venados" (León-Portilla 1992: 3-11).

Cortés tenía una esclava llamada Malinche, que hablaba maya y también náhuatl, la lengua de los aztecas. Ella era su traductora, y posteriormente se convirtió en su amante. La Malinche es conocida como la madre del México moderno debido a su unión con Hernán Cortés, que significó la mezcla de la sangre europea con la indígena. Dicha unión creó la categoría racial y cultural del "mestizo," que representa el 83\% de la población mexicana (CIA 2015).

A principios del siglo XVII los españoles, luego de someter a la población local, comenzaron a clasificar a los ciudadanos en "castas" (categorías), un sistema jerárquico de clasificación racial. Ubicaba a los españoles en la cima, con todos los derechos, y a los indígenas en el último peldaño. Las castas fueron "el producto de la mezcla de españoles con criollos, indígenas, mestizos y negros" (INAH 2009). En el siglo XVIII, esta clasificación se representaba con pinturas, las "pinturas de castas." En cada una de ellas aparecían una pareja y 
su descendencia, mostrando su color de piel, su vestimenta y sus costumbres. Estas pinturas también representaban "la estructura piramidal basada en la raza, donde los españoles tenían todo el poder político" (INAH 2009). Las imágenes creadas favorecían a los españoles, como se muestra en la figura 1 (Fig. 1) en la cual los personajes se representan de una manera dignificada, lo cual es muy distinto de la pareja de razas mezcladas que describe a un varón indígena peleando con una mulata que carga a su bebé en la espalda (Fig. 2).

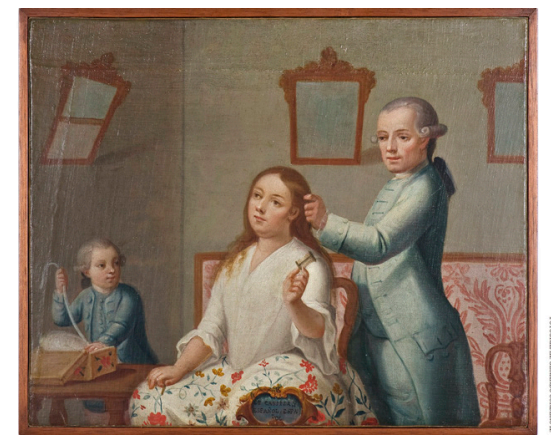

Fig.1. "Español y española con niño español

Óleo sobre tela, siglo XVIII.

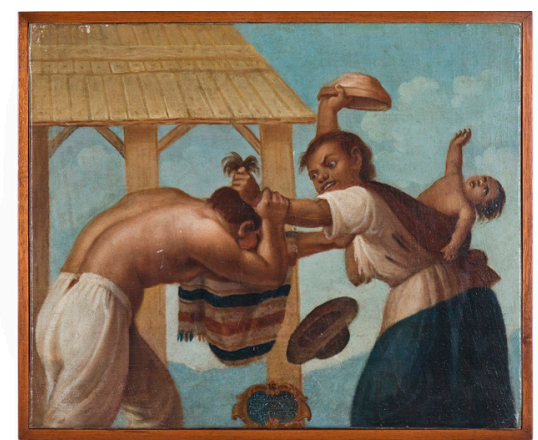

Fig.2. "Indígena y mulata con niño en la espalda". Óleo sobre tela, siglo XVIII.

CONACULTA. INAH. MÉX. Reproducción autorizada por el Instituto Nacional de Antropología e Historia. Artista desconocido. Fotógrafo: Gerardo Cordero A.

El concepto de la superioridad de la piel clara continúa hasta el presente, cuando es obvio en la cultura popular que la "segregación social" de razas y clases se refleja en la televisión nacional. La mayoría de los actores tiene una tez clara, excepto las empleadas domésticas de las telenovelas y los actores de algunos anuncios del gobierno dirigidos a la población en general (Carrillo 2009: 58).

Sin embargo, en México una persona puede tener la piel oscura y ser considerado de la clase alta. Tener la tez blanca no le da automáticamente "clase" a la gente. Hay una expresión popular, "güero de rancho", que significa persona blanca del campo o, en otras palabras, individuo blanco sin clase. Cuando los europeos llegaron por primera vez a México, descubrieron que los aztecas tenían una sociedad muy estratificada, con la nobleza en la cúpula, y después de la conquista por los españoles, Cortés decidió mantener la estructura social azteca, donde los nobles se situaban por encima de los campesinos. A medida que la Nueva España se hacía más independiente de la Península Ibérica, los españoles de la Nueva España ya no se basaron sólo 
en la raza para decidir el estatus de una persona en la sociedad. Como explica Bakewell (1997) "Hablando en términos generales, en el siglo XVI los españoles de las Indias fueron abandonando cada vez más los criterios o rangos ibéricos para ubicarse socialmente y adoptando gradualmente los nuevos estándares americanos. [...] la simple fortuna obtenida utilizando los recursos naturales pronto se convirtió en una fuerte influencia sobre la posición social" (160163). En México, una persona de piel oscura podía ser considerada de clase alta debido a su pertenencia a la nobleza azteca o porque había hecho mucho dinero. Esta sociedad estratificada aún existe; la mayoría de los empresarios del país son blancos, en parte debido al sistema de castas. Sin embargo, en política la población indígena estuvo representada por Benito Juárez, quien fue elevado al cargo máximo en 1861. Él fue el primer presidente indígena de México, proveniente de la etnia zapoteca del estado de Oaxaca. México tiene una historia complicada, y esto se refleja en la mezcla de clase y raza y en la creación del mito nacional de que México es una sociedad mestiza, una mezcla de sangre indígena y europea.

En su análisis del capitalismo y de cómo éste obtuvo el control de la economía política de México, Adam David Morton (2011), profesor de Economía Política, lo describió como una "revolución pasiva," que es "un momento de ruptura en la historia de la formación del Estado moderno, en el cual se instituyó o expandió el desarrollo capitalista". Esto dio como resultado el Estado poscolonial, cuyo desarrollo crea una sociedad desigual y favorece a la clase gobernante (239). Las familias dominantes contribuyeron al surgimiento del capitalismo en México al mantener la distinción entre clases con base en la raza y el nivel socioeconómico, reforzando el sistema de castas y aprovechándose de los trabajadores.

La hegemonía cultural se desarrolló en México a través de familias específicas pertenecientes a las clases gobernantes que mantenían el poder a través de corporaciones privadas, y "las condiciones de hegemonía se limitaban a grupos privilegiados constituidos por un núcleo central de clases dominantes" (Morton 2011:125). Las tres familias en las que me centro en este trabajo se vieron beneficiadas por la Revolución Mexicana y la clase capitalista que ésta creó, y aprovecharon su situación para controlar a las "clases sociales subalternas" a través de la comunicación, y más específicamente a través del uso de mensajes publicitarios.

\subsection{Las familias}

En 1904, Juan Servitje Torrallardona emigró a México desde Cataluña, en España. Trabajó en una panadería de la Ciudad de México llamada La Flor de México. En 1936 Lorenzo, su hijo mayor, se hizo cargo del negocio El Molino después de su muerte. Después de cincuenta años, la compañía Bimbo tuvo 
tanto éxito que "captó el 90\% del mercado en el que competía" (Patterson 2007: 257). En la actualidad, Bimbo tiene muchas marcas bajo su paraguas, y una de ellas es Barcel, su línea de papas fritas y bocadillos salados, para la cual creé publicidad de 2006 a 2009 cuando trabajé en la agencia de publicidad Young \& Rubicam de la Ciudad de México. En la lista anual de la revista Forbes (2015) de las personas más ricas del mundo, Daniel Servitje es ubicado en el lugar 310 y la corporación Bimbo es mencionada como la empresa fabricante de pan más grande del mundo.

Eugenio Garza Lagüera nació en el seno de una prominente familia española, descendiente directa de Marcos Alonso de la Garza y del Arcón, que gobernó una región de México en representación de la familia real española después de 1596. El abuelo de Eugenio Garza Lagüera, Isaac Garza Garza, fue uno de los fundadores de la Cervecería Cuauhtémoc en 1890, empresa que después se convertiría en Cervecería Cuauhtémoc Moctezuma. Una de las cervezas de esta compañía es Tecate, que ha difundido una publicidad muy controversial en México.

La familia de Alberto Bailleres González es la tercera más rica de México (Forbes), con una fortuna de 8,500 millones de dólares, ya que posee una de las minas de plata más grandes del mundo y la cadena de tiendas departamentales de lujo El Palacio de Hierro. Alberto ha sido descrito como un hombre de muchas pasiones, entre ellas la arquitectura, el diseño y la publicidad.

\subsection{Publicidad}

El novedoso informe de la Organización de las Naciones Unidas (ONU) de 2014 sobre el impacto de la publicidad y la mercadotecnia en las prácticas culturales, contiene algunas observaciones importantes sobre cómo influye la comunicación pagada en la percepción de los consumidores sobre sí mismos a través del uso de mensajes codificados, compuestos por signos y símbolos.

Las estrategias de publicidad y mercadotecnia se han vuelto más sofisticadas y las marcas han desarrollado sus propias identidades. Usando una combinación de significados, símbolos y valores, y ostentando un alcance mundial nunca visto, envían mensajes codificados a la gente y tienen éxito en convertirse en puntos de referencia para la percepción de la gente sobre sí misma, sobre los demás y sobre el mundo en general. (Shaheed 14)

Los hallazgos de este informe de la ONU demuestran que la publicidad controla cómo se mueve el consumidor dentro de su mundo sociocultural, y que los vendedores están conscientes de la influencia de las marcas en los procesos de pensamiento del consumidor. 


\section{El studio}

En el siguiente estudio exploro la forma en que los signos convencionales mexicanos se toman y rearman para crear mensajes de marca que beneficien a las tres familias dominantes en México, sin que la audiencia se entere.

\subsection{Escenario}

El estudio se realizó dentro de la economía capitalista de México. Se analizan los mensajes de marca que se difundieron por primera vez en 2014.15 en redes privadas mexicanas como Televisa y TV Azteca. Cada una de las tres marcas seleccionadas representa una compañía que es propiedad total o parcial de una familia dominante en México. Los anuncios se obtuvieron de Círculo Creativo, la única organización que representa a los trabajadores del conocimiento creativo en la industria de la publicidad en México.

\subsection{Conjunto de datos limitado}

Para analizar los datos recurrí a la teoría fundamentada modificada, la semiótica visual social y estrategias estadísticas. Inicié la investigación empleando métodos examinados en Qualitative Communication Research Methods, de Lindlof y Taylor (2011).

Los tres libros de códigos consisten en un comercial de televisión puesto al aire durante el último año por una marca mexicana propiedad de cada una de las familias mencionadas. Se lleva a cabo un análisis de la semiótica visual social de cada anuncio, creando previamente categorías basadas en el color de la piel, la clase social, los gestos, el seguimiento de textos y la mirada.

Color de la piel: Para la codificación del color de la piel, seleccioné la globalmente reconocida Fitzpatrick Phototyping Scale (Fitzpatrick 1975: 3334)(Fig 3) Esta escala reconoce diferencias en el color de la piel en vez de características raciales específicas, que tienden a ser conceptos socialmente construidos (Sachdeva 2009).

De acuerdo con la Agencia Central de Inteligencia (Central Intelligence Agency, $\mathrm{CIA}$ ) del gobierno de Estados Unidos, $10 \%$ de la población mexicana está considerado como "principalmente europeo", 62\% como mestizo (mezcla de europeo y amerindio), 21\% como "primordialmente amerindio" y $7 \%$ como "amerindio" (ClA 2015). Para los propósitos de este estudio, junto "mestizo" y "predominantemente amerindio" para representar a la mayoría de la población mexicana, lo cual da un total de $83 \%$. Ésta es una idea apoyada por el antropólogo Guillermo Bonfil Batalla, quien, en México profundo, planteó la idea de que las comunidades amerindias sobrevivientes - los mestizos rurales "desindianizados" y grandes áreas de gente pobre urbana- constituían un "México profundo", cuyas formas de vidas y cultura se basan en la civilización mesoamericana (Bonfil). Con base en estos datos estadísticos, hago la suposición 
de que "europeo" corresponde a los tipos I y II de Fitzpatrick y "mestizo" y "predominantemente amerindio" a los tipos III y IV de Fitzpatrick.

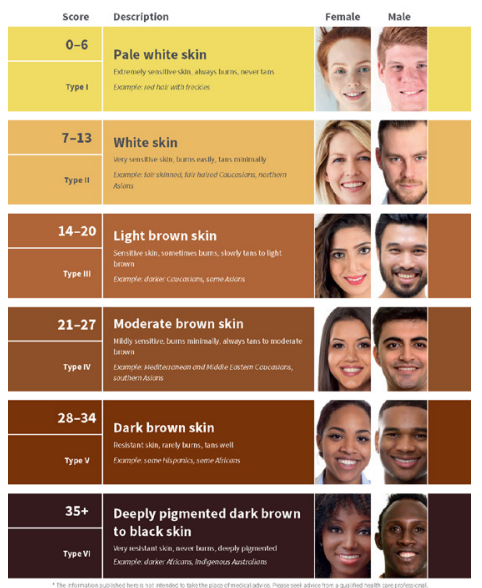

Figura 3. Tabla de Fitzpatrick (2020).

Producida por el gobierno australiano.

Clase social: Debido a la historia de México, creé un código que se refiere a la clase y a la estructura de clases.

Gestos: los gestos y el lenguaje corporal pueden considerarse un código cultural y reflejan ideas, emociones y actitudes que son dichas y no dichas por actores.

Pistas de texto: Las pistas de texto, como palabras, música y audio, se escuchan y leen en los comerciales televisivos de marcas. Las pistas de texto pueden representar signos y códigos culturales, como estatus social, conflictos, problemas y soluciones, así como un avance de la narrativa.

Mirada: Puede haber signos implícitos en el movimiento del ojo, la dirección de éste y los ángulos de cámara.

Se realizó un "análisis sintagmático" para exponer los mensajes semióticos enviados al público mexicano. Reuniré mis conclusiones de los cinco códigos de tipo de piel, clase social, gestos, pistas de texto y mirada para analizar las situaciones o escenas que integran el comercial de televisión.

\section{Resultados y análisis}

\subsection{Anuncio 1}

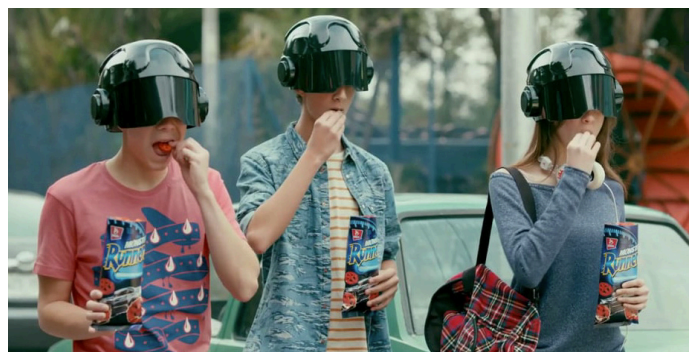

Figura 4. Escena del anuncio de televisión titulado 'Monster'.

Compañía: Bimbo; Nombre de la familia propietaria de la compañía; Servitje; Cliente:

Barcel; Agencia de publicidad: Publicis México; Producto: Bocadillo de maíz "Runners"; Título: Monster; Duración: 30 segundos; Medio: Televisión; Año de creación y exposición en medios pagados: 2014. Liga al comercial: https:// vimeo.com/136048999 (Contraseña: Mexico) 


\subsubsection{Decodificación de los signos y códigos culturales}

En su libro Mythologies (1972) Roland Barthes explica el concepto de connotación y denotación -donde el mito ocurre cuando el consumidor lee significados connotativos como denotativos-. Este concepto, aplicado al dispositivo visual del casco como se ve en el comercial de television (fig 4), produce el siguiente significado connotativo: los bocadillos Runners son en realidad un dispositivo para proteger al consumidor joven, preferentemente de piel blanca, contra la más vieja clase baja. Lo que esto significa es que un alimento hecho de maíz es realmente un casco que separa a la clase alta de la clase baja y los convierte en héroes. Este significado es social y culturalmente específico, y no una asociación natural.

Este comercial demuestra que durante una confrontación, la clase alta tiene poder sobre la clase baja. El casco es una representación de la marca Runners y demuestra cómo protegerá a los estudiantes jóvenes, de clase media alta, en su mayoría de piel blanca, en su lucha contra los "nacos" más viejos de la clase baja. Los estudiantes también cuentan con el apoyo de la mayoría blanca. Esto se refuerza con el uso de signos y códigos culturales que hacen énfasis en las diferencias de estatus económico, tipo de piel, gestos, artefactos, edad y música. Runners crea una mítica historia de lucha entre las clases media y alta burguesas contemporáneas versus la clase baja tradicional.

\subsection{Anuncio 2}

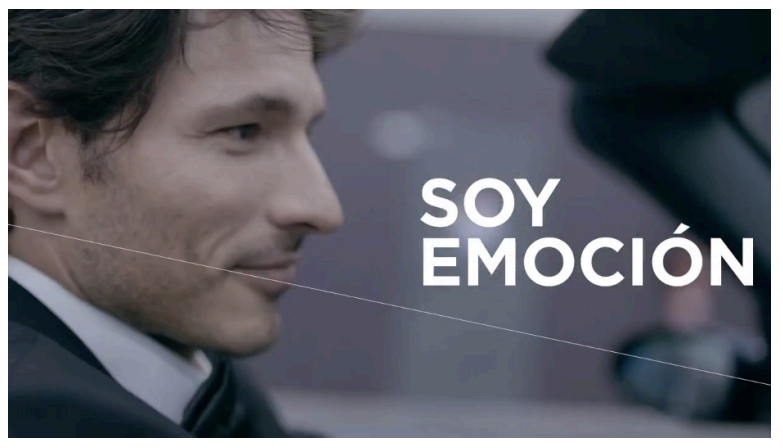

Figura 5. Escena del anuncio de televisión titulado "Andrés Velencoso"

Bailleres ; Cliente: Palacio de Hierro; Agencia de publicidad: Teran/TBWA de la Ciudad de México; Producto: Publicidad de imagen de la tienda departamental; Título: "Andrés Velencoso"*; Duración: Sesenta segundos; Medio: Televisión y cine; Año en que se creó y expuso en los medios pagados: principios de 2015; Actores: Dos actores principales en el commercial. Liga al comercial: https:// vimeo.com/136048998 (Contraseña: Mexico) https://www.youtube.com/ watch?v=-HMzETI44BI

*El comercial de TV no proviene de la competencia Círculo de Oro 2014. 


\subsubsection{Decodificación de los signos y códigos culturales}

La aplicación del concepto semiótico de lo denotativo y lo connotativo de Barthes (1972) al comercial de televisión de El Palacio de Hierro (Fig 5) produce el siguiente significado denotativo: el actor masculino, que usa lujosos artículos de marca importados que se venden en El Palacio de Hierro, es un héroe. Su significado connotativo es que productos como plástico, ropa, piel, metal y hule, cuando se reúnen en un cuerpo masculino, pueden transformarlo en un objeto sexual aspiracional. Es crear un mito de marca. Este significado es social y culturalmente específico y no una asociación natural.

El comercial está diseñado para manipular a los hombres de cualquier clase social, tipo de piel o sexualidad de modo que vean voluntariamente a través de los ojos de una mujer voyeur y sean seducidos por el actor y la marca. El comercial es una celebración del estilo de vida de los consumidores de la clase A+ y de los tipos I y II de Fitzpatrick. Demuestra cómo vive la clase gobernante. Es un mensaje que legitima a los "chicos malos malos" de dicha clase gobernante y les permite hacer lo que quieran simplemente porque pueden hacerlo. El anuncio comunica que este estilo de vida es asequible a los consumidores, por un precio. Crea un mito en el que el poderoso hombre blanco se convierte en un héroe, aun cuando sea un "chico malo," y esto se puede conseguir comprando artículos de lujo. Este héroe fabricado es capaz de seducir a quien se encuentre. El anuncio manipula al consumidor para que éste acepte y compre dentro del mito de la clase gobernante a través de la técnica de la mirada suturada. Es importante observar que, para que la hegemonía cultural funcione, no tiene que ser una decisión consciente de las familias dominantes; los signos y códigos culturales en la publicidad contienen valores que refuerzan indirectamente su poder de clase.

\subsection{Anuncio 3}

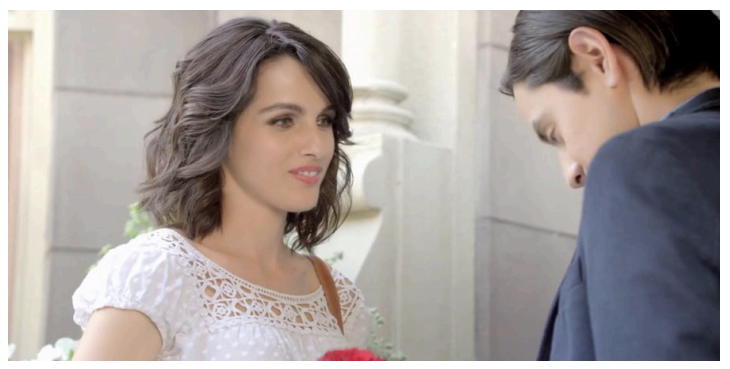

Figura 6. Escena del anuncio de televisión titulado "Choro."

Compañía:

FEMSA;

Nombre de la familia propietaria de la compañía: Familia Garza; Cliente: Heineken, Cuauhtémoc Moctezuma; Agencia de publicidad: Nómades; Producto: Cerveza Tecate; Titulo: "Choro." Año en que se creó y expuso en los medios pagados: 2014. Liga al comercial: https://vimeo.com/136048997 (La contraseña es: Mexico) 


\subsubsection{Decodificación de los signos y códigos culturales}

Barthes escribió acerca del concepto de mensaje y cómo los consumidores leen los significados connotativos como denotativos. Este concepto aplicado a la narrativa de Tecate como se ve en el comercial de television (Fig 6) produce el siguiente significado connotativo: la cerveza llamada Tecate es en realidad un caballero a los ojos de la mujer. Lo que esto significa es que una lata de metal, llena con un líquido café claro, puede convertir a cualquier hombre en un caballero de clase media, blanco, que atrae a las mujeres blancas. Este significado es social y culturalmente específico y no una asociación natural.

In The Quest for Semiotic Meaning (2007), Danesi define una narrativa como una "historia que se ensambla para reflejar la realidad de cierta manera. Es una representación de eventos humanos como son percibidos que se relacionan con el paso del tiempo [...] Con frecuencia es difícil [...] determinar la línea fronteriza entre ficción y hecho narrativo" (88). La narrativa del comercial de Tecate se construye como una fantasía romántica con el hombre tratando de escapar del "tiempo de la fantasía" para ubicarse en el "tiempo presente". La comunicación presenta una historia de la manipulación del estereotipo femenino por parte de los caballeros, todo ello apoyado por una cerveza mexicana. Los actores de piel blanca y la costosa locación envían el mensaje de que ser un "caballero" es vivir en el mundo del hombre blanco. Este anuncio crea un mensaje atractivo a los hombres de todos los tipos de piel porque presenta un deporte que es practicado por hombres de todas las razas, y es mejor que los hombres se reúnan a ver el futbol a que estén en casa con el sexo opuesto. Es un factor de unión entre los varones, patrocinado por Tecate.

\section{Conclusión}

¿Cuáles son las representaciones visuales de las relaciones de poder en la economía política de México, según se refleja en la apropiación de la publicidad? Para responder esta pregunta, investigué la historia y la economía política de México desde antes de la llegada de los europeos hasta nuestros días.

Los aztecas ya funcionaban con una estructura clasista en la que se apoyaron los españoles durante la colonización. Los españoles crearon un sistema de "castas" para clasificar a los habitantes de la Nueva España en categorías socioeconómicas y raciales. Durante el siglo XVIII, estas categorías se plasmaron en imágenes llamadas "Pinturas de castas," que ubicaban a los españoles de piel blanca en la cima de la pirámide socioeconómica y racial.

El capitalismo obtuvo el control de la economía política de México a través de lo que Morton describe como "revolución pasiva". Por medio de la hegemonía cultural, la clase capitalista estableció instituciones que tienen un carácter multiclasista o corporativista, como los sindicatos financiados por el 
Estado y las organizaciones campesinas basadas en una clara jerarquía de clase bajo el control de la clase gobernante de piel blanca.

La historia de tres familias dominantes de la actualidad, de ascendencia europea: Servitje, Bailleres y Garza, se examinaron para explorar cómo se mantiene la hegemonía cultural a través de las conexiones con el poder, y cómo la creación de mitos, vía la publicidad corporativa que contiene signos y códigos, influye en los valores sociales y culturales de México.

La difusión de información de marcas por parte de estas familias se decodificó a través de un análisis semiótico de anuncios de televisión creados por sus compañías Bimbo, Palacio de Hierro y FEMSA. Los comerciales refuerzan los mitos de la clase gobernante de piel blanca persuadiendo al público mexicano de que compre artículos de marca. Como escribió el académico Jonathan Bignel en el libro de texto Media Semiotics, "poseer el producto es 'comprar' el mito, y poseer algo de su valor social para nosotros mismos" (31-78).

De acuerdo con el análisis semiótico, se concluye que los tres comerciales presentan a actores de piel blanca pertenecientes a las clases media y alta, lo cual va en sentido contrario a la distribución demográfica del México real, donde el $83 \%$ de la población, los "mestizos", es de piel oscura (CIA) (Fitzpatrick). A través de su control del capitalismo y la comunicación, la minoría de la clase gobernante ha hecho de su estilo de vida y su color de piel una aspiración para la mayoría de la población, de clase baja y piel oscura. La clase burguesa es blanca, segura y rica, y la publicidad de marca presenta a los espectadores el mito de que es necesario protegerse de las clases inferiores; se ofrece a los consumidores artículos de marca para separarlos de la masa.

Concluyo así que la hegemonía cultural alimentada por las familias dominantes se mantiene inconscientemente a través de mensajes donde se reproducen valores que refuerzan indirectamente su poder de clase. Los valores sociales y culturales creados hace quinientos años se encuentran ahora tan inmersos en la sociedad mexicana que no son cuestionados, y forman parte de la construcción del México moderno. Las manifestaciones de poder de la economía política de México que se presentan a través de la publicidad son el mito cultivado de la clase gobernante de piel blanca.

\section{Referencias}

BIGNELL, J. 2002. Media Semiotics: an Introduction. Manchester: Manchester University Press. pp. 31-78. Retrieved from http://www.books.google.com/ books?id=MGom6ENJRLkI . (Accedido 8 Julio 2015)

BONFIL, BATALLA, GUILLERMO. 1996. Mexico Profundo: Reclaiming a Civilization Translator Philip A. Dennis. University of Texas Press. Austin. 
CARILLO TRUEBA, CESAR. 2009. El racism en mexico. Tercer Milenio. Mexico D.F., CONCACULT.

DANESI, M. 2007. The Quest for Semiotic Meaning. Toronto. University of Toronto press.

FITZPATRICK, T.B. 1975. Soleil et peau [Sun and skin]. Journal de Médecine Esthétique (in French) (2): 33-34. http://www.arpansa.gov.au/pubs/ RadiationProtection/FitzpatrickSkinType.pdf (Accedido: 27 Enero 2020).

FUCHS, CHRISTIAN. 2005. Dallas Smythe Today - The Audience commodity, the Digital Labour Debate, Marxist Political Economy and Critical Theory. Prolegomena to a Digital Labour Theory of Value. TripleC. ISSN 1726-670X

HUSSAIN, NAZIA. 2010. Not just a pretty face: the cultural contexts of beauty in Asia. WPP Atticus Awards, Highly Commended,. Pp 19. Warc.com (Accedido Julio 20 2020)

INAH . 2009. Museo Nacional de la Historia, Chapultepec, Mexico, D.F. https:// www.youtube.com/watch?v=xms7bYIHxFk (Accedido: 22 Enero 2020)

LINDLOF, THOMAS R, Y TAYLOR. 2011. Qualitative Communication Research Methods. Thousand Oaks. Sage publications.

LIZCANO FERNANDEZ, FRANCISCO. 2005. "Composición Étnica de las Tres Áreas Culturales del Continente Americano al Comienzo del Siglo XXI". Convergencia. Revista de Ciencias Sociales, num. Mayo-Agosto, Academic investigation (in Spanish). University of the State of Mexico 196. 185-232.

MORTON, ADAM DAVID. 2011. Revolution and State in Modern Mexico: The Political Economy of Uneven Development. Lanham, MD: Rowman \& Littlefield,

PATTERSON, JORGE, ZEPEDA. 2007. Los amos de Mexico. Mexico D.F. Editorial Planeta Mexicana.

SACHDEVA, S. 2009. Fitzpatrick skin typing: Applications in dermatology. Indian J Dermato/ Venereol Leprol. 75:93-6. http://www.bioline.org.br.ezproxy.lib. ryerson.ca/pdf?dv09029 Accedido: 8 August 2015

SHAHEED, FARIDA. 2014. United Nations Special Rapporteur in the field of cultural rights. Sage. p. 900

http://daccess-dds-ny.un.org/doc/UNDOC/GEN/N14/499/88/PDF/N1449988. pdf?OpenElement

http://ap.ohchr.org/documents/dpage_e.aspx?si=A/69/286 (Accedido: Julio 21 2017) SMYTHE, D.W. 1977. Communications: Blindspot of Western Marxism. Canadian Journal of Political and Society Theory 1 (3): Toronto.p. 1-28 


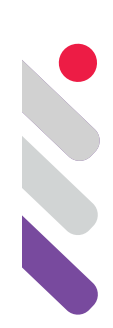

\section{Adverfilms y fenómenos de retoma: una aproximación sociosemiótica a la discursividad publicitaria en plataformas interactivas.}

DOI: 10.24308/IASS-2019-5-022

Lic. Lorena Steinberg Carrera de Ciencias de la Comunicación, Facultad de Ciencias Sociales, Universidad de Buenos Aires, Proyecto UBACyT (2018-2021):

"Retomas discursivas en tiempos de convergencia: producción, circulación, consumo", dirección Prof. María Rosa del Coto.

lorenasteinberg@gmail.com

\section{Introducción}

En el contexto general de nuestra investigación preocupada por el estudio de fenómenos de retoma en tiempos de convergencia, esta ponencia buscar analizar una serie de textos audiovisuales desarrollados en el marco de escenarios interactivos caracterizados por convergencias mediáticas (Jenkins, 2006), definidas según el autor, como "flujo[s] de contenido[s]" que circulan a través de "múltiples plataformas mediáticas" y que a la vez implican la cooperación entre las diversas plataformas, las industrias y el comportamiento "migratorio" de las audiencias (Jenkins, 2008:14).

El objetivo de este trabajo es analizar las operaciones de producción de sentido en sus tres dimensiones (icónica, indicial y simbólica) para dar cuenta de los fenómenos de retoma presentes en tresadverfilms: Look Up de Gary Turk(2014), \#conexiónreal de José Cicala y Nicolás Cuño (2016) y \#DesconectaParaConectar, creada por porMcCann y MRM/McCann (2018).

El primero fue escrito y dirigido por Turk, un cineasta inglés. Se viralizó en 2014 a partir de su publicación en YouTube. El adverfilm dirigido por Cicala y Cuño en 2016 pertenece a la marca de ropa argentina Key Biscayne. Fue seleccionado para participar en el Festival de Cannes y Desaconecta para conectar, es la campaña elaborada por la marca IKEA, la compañía sueca dedicada a la fabricación y venta de artículos para el hogar, que se difundió 
en España para revelar lo poco que se sabe de las personas más cercanas y queridas.

Desde un enfoque de la Teoría de los Discursos Sociales de Eliseo Verón (1993 [1988]), el estudio consiste en el relevamiento de los tres órdenes de configuración significante a partir de la descripción de operaciones icónicas (referidas a imágenes visuales), indiciales (referidas a marcas audiovisuales, sonoras, gestuales y verbales) y simbólicas (referidas tanto a marcas lingüísticas como a convencionalizaciones sociales). En particular, se llevará adelante un análisis en producción, esto es, un análisis que puede describir la gramática de producción de los exponentes textuales anteriormente mencionados, a partir de los cuales se puede inferir "un campo de efectos posibles de sentido" (Verón, 1993: 20).

En el contexto actual, que tiene a la tecnología como uno de los principales motores de cambio, las marcas se encuentran con consumidores informados y críticos y comienzan a cobrar importancia "los valores intangibles de las marcas" (Domingo y Martorell, 2011: 14). Las nuevas tendencias que se generan en el discurso publicitario también se hacen visibles en los tresadverfilms estudiados, en los cuales se publicitan las marcas: de Key Biscayne como marca de ropa, de Gary Turk como cineasta, escritor y youtuber e IKEA, como marca de productos para el hogar. En los tres casos mencionados, se evidencia como valor, la preocupación por el impacto de las redes sociales en las relaciones humanas. Es en este marco en el cual es interesante analizar contrastivamente las operaciones de producción de sentido para abordar una problemática que manifiesta una "responsabilidad social empresaria" por parte de las compañías.

\section{Descripción del corpus}

Los tres adverfilms tienen la misma temática, es decir, abordan el impacto del uso de la tecnología en las relaciones humanas. En los tres casos se vincula el alto grado de "conexión" a las redes con la "desconexión" de los seres queridos. En el primer corto, Turk, director y YouTuber, habla directamente a los ojos del destinatario, interpelándolo para que concientice la importancia de levantar la cabeza del celular y mirar a quienes nos rodean. El video describe una serie de situaciones en las compara cómo hubiese sido la situación de dos jóvenes si cuando se hubieran cruzado cada uno hubiera seguido mirando su pantalla del celular, en lugar de mirar a los ojos a la otra persona. El segundoadverfilm," \#conexión real", perteneciente a la línea de ropa Key Biscayne, cuestiona el uso de las tecnologías en forma adictiva, lo que genera la invisibilidad de los demás con los cuales se interactúa. Se representan distintas situaciones que observa el protagonista, mientras viaja en el auto con su hijo, que está inmerso en la pantalla de su dispositivo móvil. Las situaciones que observa son, a modo de ejemplo, un ciego que quiere cruzar la calle, y otra persona, por estar viendo 
su celular, no lo mira para ayudarlo; dos padres juegan con su hija a saltar la soga, cada uno absorto con su teléfono; otros llevan a su hijo en el cochecito. En todos los casos, lejos de prestar la atención necesaria a sus seres queridos, están concentrados mirando la pantalla de su celular, sin "registro" del otro. El último, producido para IKEA (fabricante y vendedor de productos para el hogar) aborda la misma temática desde un concurso de preguntas y respuestas entre familias, que llevará a sus integrantes a reflexionar acerca de cuánto saben de las celebridades e influencers y el desconocimiento que tienen de sus familiares.

Look Up, Gary Turk (2014)

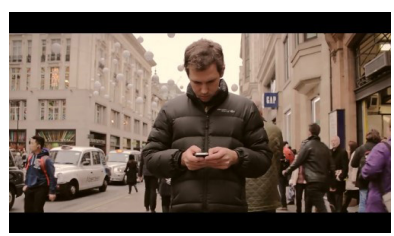

\#Disconnect to Connect, McCann y MRM/McCann y Nicolás Cuño (2016)

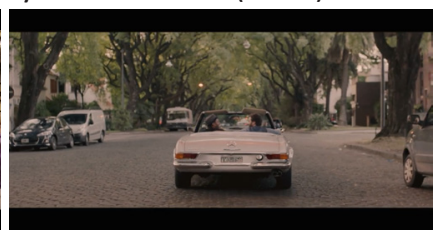

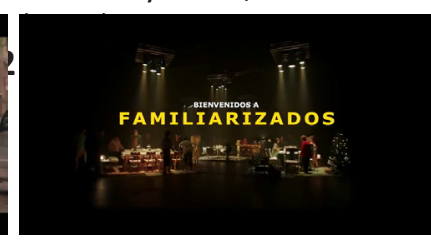

\section{Análisis del corpus}

Las marcas apelan a la emotividad de los consumidores para generar un efecto de concientización en el uso responsable de las redes sociales y la tecnología.¿Cuáles son las operaciones que utilizan los adverfilms para lograr conectar a los consumidores con cada una de las marcas? ¿Qué estrategia construye el discurso de cada una de ellas?

Cabe mencionar que los tres AdverFilms tienen diferentes condiciones de producción y es por eso que recurren a diferentes formatos para construir sentido.

"Desconectados para conectar" de Ikea, remite a un programa de concursos de televisión. También tiene como condición de producción la idea de Navidad como unión familiar.

"Conexión real" de Key Biscayne tiene un formato de cortometraje (de hecho, fue presentado en Cannes).

"Look up" de Gary Turk tiene como condiciones de producción los poemas, así como el formato de muchos videos de YouTube (con la operación esencial de hablar y mirar a cámara).

Es interesante subrayar que la representación de "la familia tipo, heterónoma"se la puede encontrar en todos los adverfilms. En el caso de Look up, un joven conoce a otra mujer con la cual se casa, forman una familia y tienen hijos. En el exponente textual "Conexión real”, Guillermo y Nicolás Francella, justamente representan a un padre con su hijo, y además, se visualizan distintas familias con sus hijos también, jugando en una plaza, paseando por la calle, etc.

Otra operación simbólica que se puede observar en el corpus, es la 
representación del "Desconectarse para conectarse". Vale decir, dejar la obsesión por las redes y vincularse con los seres queridos. En este sentido, no se apela a un uso "responsable" de la tecnología, sino a la desconexión. Esto da cuenta de una posición binaria del enunciador: conectados obsesivamente o desconectados para reivindicar los lazos familiares. Se podría inferir, que dado que se trata de un discurso publicitario, adquiere una gran preponderancia la función conativa del lenguaje (Jakobson, 1985), así como también, la pregnancia del "mensaje publicitario", que se incrementa en relación a facilitar la lectura por parte del potencial consumidor.

Los tres adverfilms proponen un cambio de actitud por parte del potencial consumidor, es decir, "apagar" sus pantallas para conectarse con los seres queridos.

\subsection{Operaciones de sentido en los tres órdenes de la configuración significante}

En los tres adverfilms se utiliza la operación de invisibilizacióndel otro, que ilustra su ausencia. Remite a una operación indicial e icónica. Por un lado, interpela al destinatario y llama su atención sobre lo que "no se ve", y por el otro, es una metáfora del no registro de los demás.

Con respecto al tipo de focalización, según Gaudreaulty Jost(2002) se relacionaría con la focalización interna, dado que desde el punto de vista cognitivo, el saber está filtrado por la figura del enunciador.

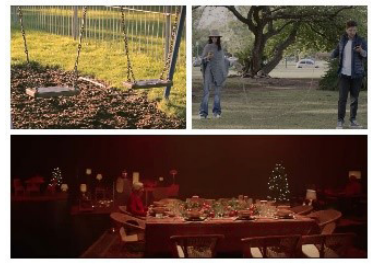

Ausencia

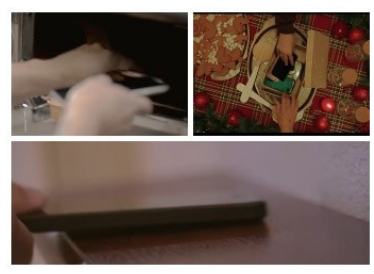

Desconexión

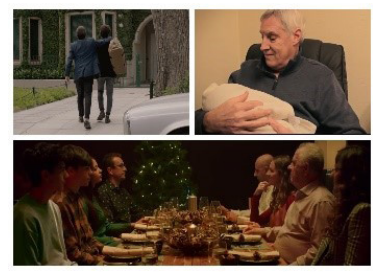

Reivindicación de lazos familiares

Con respecto a la ocularización y auricularización de los mismos autores, se articulan en los tres adverfilms la auricularización interna y cero, así como también la ocularización, dependiendo de cada situación representada. Cuando los protagonistas se acercan a determinadas escenas, se articula la interna y cero para dar idea de un protagonista que juega el rol de observador y analista de las circunstancias cotidianas que los rodean, así como también la ocularización cero para impactar con el grado de cotidianeidad de las situaciones representadas. Por lo tanto, cuando el enunciador quiere mostrar una estandarización en lo que genera la adicción a la tecnología, se emplea la ocularización y auricularización cero; cuando el enunciador realiza una valoración y evaluación de lo que es mostrado, ambas categorías pasan a ser internas. 
Si se toma en consideración los índices comentativos (Bettetini, 1984), se prioriza el comentario explicitado verbalmente en los tres adverfilms. A modo de ejemplo, en el aviso de lkea, se escucha la voz en off que pregunta, ¿te jugarías la cena de navidad con tu familia? En el caso de Conexión real, en los créditos se puede leer, "y gracias a vos, sí, a vos", lo que evidencia una relación explícita entre enunciador y enunciatario. En look up, "levanta tu cabeza", haciendo alusión a una modalidad de enunciación imperativa, para interpelar al destinatario. En estos ejemplos, se hace alusión a operaciones indiciales, para llamar la atención del enunciatario, y simbólicas, al ser lingüísticas.

Otra de las categorías que se pueden aplicar de Bettetini (1984) es la del comentario atemporal. En los tres avisos se puede observar que la "desconexión" está asociada a una imagen en donde se representa dicho concepto con dejar los celulares en una caja, en el caso de Ikea; en una mesa, en el caso de Look up y guardarlos, en el caso de Conexión real. Se puede visualizar una evaluación y valoración del enunciador, que remarca esa conducta desde una toma en picado, en el caso de Ikea, "desconectar para conectar", mientras que en Look Up y Conexión real, se recurre a un plano detalle para subrayar la importancia de dicha conducta.

Otro elemento a destacar es el rol que juega la música en los tres adverfilms. Cambia los ritmos de las imágenes, aventura unamodificación en el clima y en la conducta de los protagonistas de los tres cortos. La musicalización cobra un papel prioritario en lo que respecta a representar un quiebre en los relatos, los que se resuelven a modo de desenlace, con la reivindicación de los lazos familiares, como consecuencia de la desconexión con las redes sociales.

\section{A modo de cierre}

Se puede concluir que en los tres adverfilms la estrategia del discurso apunta a interpelar directamente al espectador, en tanto potencial consumidor de los valores de cada una de las marcas, más que de sus productos.

Se representa y coloca a la niñez/familia como factores en riesgo por la adicción de los adultos a la tecnología, y la manera en que esta conducta impacta en las relaciones humanas.

Una de las operaciones fundamentales de construcción del sentido se relaciona a la utilización del recurso de invisibilizaciónmaterial y simbólica del otro para mostrar ausencia, aislamiento.

Esta operación indicial e icónica podría movilizar al potencial consumidor a reflexionar con respecto a la necesidad de producir un cambio de conducta. La solución a este problema es la desconexión del mundo digital. Apartar a la tecnología, alejarse de ella. Cabe mencionar que la representación binaria de las situaciones, vale decir, la adicción o el alejamiento de la tecnología podría generar un efecto de pregnancia en el destinatario, para interpelarlo con un 
razonamiento evocado que se vincule con "si quiero mantener y enriquecer mis vínculos afectivos, tengo que desconectarme".

La banda sonora acompaña los diferentes momentos y el estilo de los relatos. A modo de ejemplo, en el caso de "Desconectar para conectar" de Ikea, el sonido inicial hace referencia intertextual a los juegos televisivos de preguntas y respuestas, con toda la impronta que los caracteriza. Por ejemplo, la música inicial del programa, el timbre que pauta el tiempo de inicio y finalización de los turnos de los familiares para responder, así como también, la música que incita a la reflexión del destinatario.

En el caso de Conexión real, se observa continuamente una voz en off que narra y comenta lo que se representa en las imágenes, a modo de orientar la interpretación del destinatario. Cabe mencionar que las escenas en las que aparecen las familias y personas desconectadas, no tienen sonido ambiente, sino que la música es de foso, para ambientar y comentar las imágenes.

En Look Up la música acompaña el ritmo de las imágenes, desde hacerlas más lentas hasta acelerarlas, para representar la vorágine que implican las redes sociales.

Otra operación de sentido que se emplean en los tres avisos, es la presentación de textos escritos para captar la atención del espectador. Se muestran en la pantalla para interpelar al destinatario a través de una función del lenguaje conativa, contemplando los conceptos de Jakobson (1985), tal como se mencionara anteriormente.

Si se considera a las operaciones intertextuales, cabe destacar que en el caso de Ikea, se hace alusión a los realitygame shows, a la fiesta navideña, al documental, cuando los familiares reflexionan acerca de su desconocimiento de sueños, gustos y preferencias de sus familiares y su gran conocimiento de las celebridades y los influencers que habitan las redes sociales. Cuando el conductor del juego comienza a interrogar sobre asuntos familiares, el plano se va ampliando, ya no solamente muestran al encuestado, sino también a la persona que está involucrada en la pregunta personal que el locutor hace, interpelando a la emoción de los mismos, dejando en evidencia la desilusión de cada miembro de las familias por no responder correctamente, esto acompañado de fondo con música melancólica. Un plano cenital muestra las mesas vacías, como consecuencia del desconocimiento de la vida de cada uno de los familiares.Luego vuelven a sentarse en la mesa y dejan el celular en una caja que se encuentra en el centro de la misma. Aparece el texto "cada día tenemos la oportunidad de conocer mejor a las personas que nos rodean". En este caso, también se utiliza un nosotros inclusivo para interpelar al destinatario. Luego se escucha el sonido de las familias dialogando.

En relación a Conexión Real, se hace alusión a los discursos que funcionan socialmente sobre el impacto de la tecnología en las relaciones humanas, las 
limitaciones que posee. Asimismo, se retoma el marco normativo de la marca Key Biscayne, es decir, su misión, visión y valores de dicha marca. De esta manera, se subraya su preocupación por problemáticas sociales, tales como la adicción a la tecnología. Esta conducta representa una responsabilidad social por parte del discurso institucional de la empresa y la marca.

En vinculación con Look Up, se hace referencia a los videos de youtubers, a los poemas, a los documentales que hacen alusión a la relación hombre y tecnología.

Las tres marcas destacan como atributo positivo a la familia tipo, ya que por el status social al que apuntan las marcas, se la toma como un valor. En pos de cuidar a la familia, en los tres adverfilms se representa un quiebre en el relato que implica dejar de lado el celular, la tecnología para reconectarse con los lazos familiares. Dicho punto de inflexión se subraya a través de los ralenti, los planos detalle, primerísimos primeros planos, planos picados, así como también en la banda sonora en general y la música de foso en particular.

Las marcas apelan a la emotividad de los consumidores para generar un efecto de concientización en el uso responsable de las redes sociales y la tecnología. La participación masiva de los consumidores en las redes sociales y en las comunidades online ha generado que las marcas se adapten a una nueva forma de consumo. Como mencionan en su conclusión Gemma y Martorell es preciso mantener "una relación basada en la confianza, la transparencia y la emocionalidad. La marca debe ser para sus consumidores una fuente de experiencias positivas en todos los aspectos que los vinculan" (GemmaMartorell, 2011:22). Los consumidores pueden participar de las campañas que las marcas propongan, a través de las distintas plataformas, compartirlas, acceder a ellas de manera masiva, en muchos casos de manera gratuita. De esta manera las marcas, en sus discursos publicitarios, deben encontrar la forma de comprometerse y adaptarse a las nuevas condiciones de relación con su audiencia. Es en este marco en el cual la responsabilidad social empresaria adquiere una vital importancia para los consumidores, vale decir, cómo la marca toma en consideración el contexto, la comunidad en la cual está inserto el producto. En consecuencia, "las preocupaciones y problemáticas que aborde la marca, permitirán que puedan interpelar al destinatario en tanto potencial consumidor, en este caso, apelando a la emotividad para generar un efecto de concientización en el uso responsable de las redes sociales y la tecnología.

\section{Bibliografía}

BETTETINI, Gianfranco. 1984. El Tiempo de la expresión cinematográfica. México D.F.: Fondo de Cultura Económica (FCE). 
CHION, Michel. 1993. La escena audiovisual, en La audiovisión. Introducción a un análisis conjunto de la imagen y el sonido. Barcelona: Paidós.

DOMINGO, Gemma y MARTORELL, Cristina. 2011. "Una mirada al consumidor de hoy (y de mañana) desde la publicidad”, en Trípodos, N²8, pp. 13-23. Barcelona: Facultat de Comunicació, Blanquerna.

GAUDREAULT, André y JOST, François. 2002. "El punto de vista", en El relato cinematográfico. Barcelona: Paidós.

JAKOBSON, R. 1985. "Lingüística y poética" (pp. 347-365) en Ensayos de Lingüística General. Barcelona, Ariel.

JENKINS, Henry. 2006. Convergence Culture: Where Old and New Media Collide. Nueva York: UniversityPress.

PEIRCE, Charles. Sanders. 1978. Fragmentos de la ciencia de la semiótica. Buenos Aires: Nueva Visión.

ROCHA ALONSO, Amparo. 2008. De lo indicial, lo icónico y lo simbólico en las manifestaciones del sentido. Material de Semiótica de los Medios, Cátedra Prof. María Rosa del Coto. Buenos Aires: Facultad de Ciencias Sociales, UBA.

SEMPRINI, Andrea. 1995. El marketing de la marca. Selección de fragmentos. Barcelona: Paidós.

STAM, Robert. 2001. Del texto al intertexto, en Teorías del cine. Barcelona, Paidós.

VERÓN, Eliseo. 1987. La semiosis social. Fragmentos de una teoría de la discursividad. Barcelona. Gedisa.

1995. "Semiosis de lo ideológico y del poder", en Semiosis de lo ideológico y del poder. La mediatización. Buenos Aires: Facultad de Filosofía y Letras, Universidad de Buenos Aires (UBA). 


\section{Índice general de las Actas}

\section{TOMO 1}

\section{TRAYECTORÍAS Y TEORÍAS}

COORDINADORES: MARÍA TERESA DALMASSO Y CLAUDIO GUERRI

LOS ARCHIVOS PERSONALES DE ELISEO VERÓN. Gastón Cingolani

DE LAS OPERACIONES SEMIÓTICAS A UNA SEMIÓTICA DE LAS OPERACIONES. María Elena Bitonte

LAS "SEMIOSIS SOCIALES" Y LAS TRANSFORMACIONES EN LOS PROCESOS COMUNICATIVOS. Gustavo Aprea

ELISEO VERÓN ENTRE DOS SEMIOSIS: DEL CUERPO SIGNIFICANTE AL CEREBRO DEL SAPIENS. Amparo Rocha Alonso

THE SEMIOTIC THEORY OF A.J. GREIMAS IN MAINSTREAM ORGANIZATION THEORY AND ORGANIZATION RESEARCH. Pertti Ahonen

ÉCOLE RUSSE ET ÉCOLE FRANCAISE DE SÉMIOTIQUE. VALEURS, FORMES DE VIE ET TRAJECTOIRES HISTORIQUES. Inna Merkoulova

TRAJECTÓRIAS DO LEITOR NO ESPAÇO TEXTUAL.

Maria Augusta Babo

DE LAS PASIONES EN LA ENUNCIACIÓN. TEORIZACIÓN E IMPLICANCIAS PARA EL ANÁLISIS SEMIÓTICO DE LOS DISCURSOS. Cristian Cardozo

ALIQUID PRO ALIQUO. ASOCIACIÓN, REPRESENTACIÓN Y SIGNIFICACIÓN. Fernando Rodríguez

DUALISM IN AL-FARABI'S WRITINGS AND LANGUAGES.

Driss Bouyahya

ALGUNAS OBSERVACIONES SOBRE EL GIRO LINGÜÍSTICO EN LA HISTORIA INTELECTUAL. Norma Fatala 
MASS-MEDIACIÓN: FORMATO Y DISPOSITIVO. Marcelino García

SOBRE LA VERDAD SEMIÓTICA Y PRESEMIÓTICA DE LA IMAGEN. Fernando Fraenza y Valentino Indorato

PROSPECTIVE AND SIGN IN ITS EVOLUTIONARY NATURE. Bianca Suárez Puerta

SEMIÓTICA DAS ORGANIZAÇÕES: ENTRE AS TESSITURAS TEXTUAIS E AS REDES DE SENTIDO. Elisangela Carlosso Machado Mortari

LA FILIGRANA MOMPOSINA: PRESERVACIÓN DE LA TRADICIÓN A TRAVÉS DEL APRENDIZAJE. Denis Senith Cabrera Anaya

SIGNS IN ACTION: OLD HERITAGE CRAFTS AND NEW

"SENSE KEEPERS". Nicolae-Sorin Drăgan

TRAYECTORIAS DE UN MODELO OPERATIVO: NONÁGONO SEMIÓTICO. Claudio F. Guerri

REORIENTANDO LA MÚSICA: UN ABORDAJE PEIRCEANO DE LA PERFORMANCE MUSICAL. Juan Pablo Llobet Vallejos y Pablo Stocco

APROPIACIÓN MATERIAL. TRAYECTORIAS, PROFANACIONES Y ESTRATEGIAS EN EL ARTE CONTEMPORÁNEO DE AMÉRICA LATINA. Guadalupe Ailén Álvarez

TRAYECTORIAS PERFORMÁTICAS DEL ARCHIVO EN LA ERA DIGITAL. \#VIVAS: TECNOLOGÍAS DIGITALES PARA LA CONSTRUCCIÓN DE MEMORIA COLECTIVA.

Guadalupe Ailén Álvarez, Maximiliano Cortés y Micaela Flavia Paz

GESTIONAR LA SOSTENIBILIDAD DE LAS ORGANIZACIONES COMO UNA TRAYECTORIA HACIA LA RESPONSABILIDAD SOCIAL.

Raquel Felisa Sastre

NONAGONO SEMIÓTICO DEL SIGNO GOBIERNO: UNA PROPUESTA PARA RECONOCER Y MINIMIZAR RELACIONES DE DOMINACIÓN. Juan Emilio Ortiz

¿"BOLUDA" O "BOLUDA DE MIERDA"? CONVERGENCIAS Y DIVERGENCIAS EN LAS TRAYECTORIAS DE DOS SIGNOS. Paula Elizabeth Fainstein 
ARCHIVOS QUE PERFORMAN. APROXIMACIONES SEMIÓTICAS A LAS PRÁCTICAS DE ARCHIVO. Claudio Guerri, Martín Acebal y Cristina Voto

THE TRAVELER'S GAZE: A SEMIOTIC ANALYSIS OF INSTAGRAM'S TRAVEL PHOTOGRAPHS. Fernanda Carvalho Ferrarezi

NEUROSEMIOSIS - TRANSITION FROM PHYSICAL TO MENTAL STATES. Karl Gfesser

PEIRCEAN SEMIOSIS AND THE ENGINEERING OF CONSENT AS PARALLEL TRAJECTORIES. Tony Jappy

SEMIÓTICA Y HERMENÉUTICA: REFLEXIONES METODOLÓGICAS EN BASE AL CONCEPTO DE SIGNO EQUÍVOCO. Roxana Cecilia Ynoub

SYNALETHISM AND UNLIMITED SEMIOSIS. Titus Lates

SEMIOTIC APPROACH TO IRONY. Evelyn Vargas

THE POWER OF IMAGINATION. NEW APPROACH TO CHARLES PEIRCE'S ABDUCTION. Reni Yankova 


\section{TOMO 2}

\section{ALTERIDADES, IDENTIDADES}

COORDINADORES: MARITA SOTO Y FEDERICO BAEZA

NO ES LO QUE PARECE. EDUARDA MANSILLA, VOCES FEMENINAS DESDE LA FRONTERA INTERIOR. Laura Sacchetti

LA MIRADA SEMIÓTICA AL DISCURSO SUFRAGISTA EN MÉXICO (1916-1923). Olga Nelly Estrada y Griselda Zárate

LOS AMORALES Y LAS "BUENAS COSTUMBRES": MEMORIA DISCURSIVA Y CLASIFICACIÓN DE LA DISIDENCIA SEXUAL EN LA DIPPBA. Paulina Bettendorff y Laura Bonilla

ENCYCLOPEDIC ANTHROPONYM AS THE SIGN OF CULTURE. Svetlana Bogdanova y Elena Ignatieva

THE CORSET AND THE HIJAB: ALTERNATIONS OF ABSENCE AND PRESENCE IN THE 19TH AND 20TH-CENTURY FASHION SYSTEM. Marilia Jardim

ENTRE ORILLAS. TRAYECTORIAS DISCURSIVAS DE LA IDENTIDAD GALLEGA EN LA ARGENTINA. Claudia López

LOS VARRIOS DE SAN DIEGO CALIFORNIA. RESISTENCIA CHICANA-CONCHERA. José Luis Valencia González

LA PREGUNTA POR EL CUERPO EN LA SEMIÓTICA CONTEMPORÁNEA: PERFORMATIVIDAD, VINCULACIÓN Y MEMORIA. Susana Temperley

INTERSUBJETIVIDAD, MULTIMODALIDAD Y ADQUISICIÓN DEL LENGUAJE. Fernando Gabriel Rodríguez

TRAJECTORIES OF POSSIBILITIES. SEMIOTICS OF THE UNPREDICTABLE FUTURE. Katarzyna Machtyl 
BETWEEN SEMEIOTICS AND SEMIOTICS: THE BODY AS A SIGNIFYING TEXT. Simona Stano

LA PRAXIS ENUNCIATIVA Y LO REAL: ARTICULACIONES INTERDISCIPLINARIAS PARA UN MODELO DE ANÁLISIS DEL DISCURSO. Marcos Javier Mondoñedo Murillo

LIBIDINAL INTELLIGENCE: CINEMA AND LITERATURE. Roseli Gimenes

SEMIOTIC STRATEGIES TO CREATE HERITAGE: LUXURY FASHION BRANDS IN THE AGE OF SOCIAL NETWORKS. Daria Arkhipova

LA ESCENOGRAFÍA DEL CUERPO EN EL DISEÑO DEL DESFILE DE MODA. Mihaela Radulescu de Barrio de Mendoza

TRAYECTORIAS DISCURSIVAS: LA ALIMENTACIÓN ENTRE CIENCIA Y COMUNICACIÓN. Simona Stano

A CIDADE COMO ESPAÇO DE COMUNICAÇÃO MERCADOLÓGICA: O POTENCIAL DE PRODUÇÃO DE SENTIDO DAS MARCAS A PARTIR DE INTERVENÇÕES PUBLICITÁRIAS NO CONTEXTO URBANO. Sergio Marilson Kulak y Rui Torres

\#YOSOYDIVERSO, MÁS QUE UN HASHTAG, UN LLAMADO A LA TOLERANCIA DESDE LA PERSPECTIVA DEL PLURALISMO CULTURAL EN LA VIRTUALIDAD.

Norberto Fabián Díaz Duarte y Antonia María Moreno Cano

BARRIOS EN FOCO: EL DISCURSO AUDIOVISUAL ENTRE LO TRANSLINGUISTICO Y LO TRANSDISCIPLINAR. Valeria Car, Alfredo Isasmendiz - Preti y Cinthia Naranjo DISCURSOS, PIQUETES Y ORDEN DEMOCRÁTICO. Liliana Pazo ANÁLISIS SEMIÓTICO DE LA REPRESENTACIÓN DE GÉNERO EN LA PELÍCULA PERSÉPOLIS. Lucía Leticia Anaya Avilés

LA PERSISTENCIA DEL AMOR ROMÁNTICO: ANÁLISIS DE SU REPRESENTACIÓN E INFLUENCIA EN LOS ROLES DE GÉNERO TRADICIONALES EN RUBY SPARKS Y LA LA LAND DESDE LAS FIGURAS DE EROS Y PSIQUE.

Itzel Mayelli Flores Urzua y José Honorio Cárdenas Vidaurri 


\section{TOMO 3}

\section{ESCRITURAS E HISTORIAS}

COORDINADORA: VANESA PAFUNDO

THE JEALOUS NARRATOR: ANALYSIS OF THE ENUNCIATION STRATEGIES IN ROBBE-GRILLET'S NOVEL LA JALOUSIE. Ludmila Lacková

UN NO- LUGAR COMÚN EN LA LITERATURA: LO INFINITO. Karina B. Lemes

LA TRAYECTORIA DE LA MIRADA SARAMAGUIANA. UN ANÁLISIS DEL DISCURSO SOBRE EL ARTE EN LOS CUADERNOS DE LANZAROTE, DE JOSÉ SARAMAGO. Marisa Leonor Piehl

ALGUNOS APUNTAMIENTOS DE JOSÉ SARAMAGO DESDE LA EMOCIÓN DE LOS SUCESOS DEL PROCESO REVOLUCIONARIO EN CURSO - PORTUGAL, 1974-1975. María Victoria Ferrara

FORMAS DE LA "AUTORÍA TRANSMEDIA" ACERCAMIENTOS SEMIÓTICOS. María Clara Lucifora

WHO IS THE DREAMER? TEXTUAL AND METHODOLOGICAL SEMIOTIC TRAJECTORIES IN TWIN PEAKS: THE RETURN. Giacomo Festi

ELENA SABE: LA EXHIBICIÓN DE UNA SOCIEDAD EN CRISIS. Karina Lemes

PROSA MESTIZA. CONFIGURACIONES DE LA FRONTERA EN TRES NOVELAS ARGENTINAS CONTEMPORÁNEAS. Froilán Fernández

MONSIEUR PAIN. NARRATIVA DE ORILLA.

Natalia Vanessa Aldana

HARRY POTTER: ANÁLISE DAS CAPAS DOS LIVROS.

Júlia Meister Barichello 
DO OBJETO LIVRO AO LIVRO-OBJETO LITERÁRIO:

UMA RESSEMANTIZAÇÃO SENSÍVEL. Marc Barreto Bogo

ENTRE O VERBAL, O GRÁFICO E O ESCULTÓRICO:

INTERSEMIOTICIDADE NA PUBLICAÇÃO TREE OF CODES. Marc Barreto Bogo

SALOMÉ: UN CASO DE RECURRENCIA DISCURSIVA. Oscar Traversa

EL HÉROE CONTEMPORÁNEO - NUEVAS TRAYECTORIAS

DE SIGNIFICADO ÉTICO. Rafael Zanlorenzi

REPRESENTATION AS A CATALYST FOR CULTURE CHANGE PROCESSES: THE SEMIOTICS OF CULTURE CHANGE.

Hamsini Shivakumar

CONTRAPUNTOS CRÍTICOS TERRITORIALES. ESCRITURA, RITMO, SONORIDAD. Carmen Guadalupe Melo

TRAVESÍAS Y ENCRUCIJADAS DEL ARCHIVO: DISCURSIVIDADES POÉTICAS Y TERRITORIALES. Carla Vanina Andruskevicz

IDENTIDAD Y FRONTERAS DENTRO DE LA OBRA: MEMORIAS DEL SUR - PRIMEROS RESULTADOS DE INDAGACIÓN.

María Leticia Scarpa

ESTRATEGIAS NARRATOLÓGICAS PARA EL ANÁLISIS DE MATERIAL AUTOBIOGRÁFICO: ¿A QUIÉN ESCRIBEN LOS QUE SE ESCRIBEN? Maité Delfina Lluch

A CONSTRUÇÃO DOS ATORES E SUA PROJEÇÃO NO ESPAÇO-TEMPO EM A CIDADE DORME, DE LUIZ RUFFATO. Marcela Ricardo y Vera Lucia Rodella Abriata

PASADOS EN TRÁNSITO: RELATAR DESDE EL OLVIDO. Sergio Rojas

SEMIÓTICA NARRATIVA E IMAGINARIO HUMANO: REFLEXIONES METODOLÓGICAS EN BASE A LOS APORTES DE GREIMAS Y PROPP. Maité Delfina Lluch, Miguel Adrián Romero y Roxana Ynoub

HACÉ MEMORIA, NO MONUMENTOS. HACIA LA CONSTRUCCIÓN DE ARTEFACTOS ESTÉTICO-SEMIÓTICOS (DES)EMPLAZADOS. Ariel Barbieri 
SEMIOTIC MULTIMODALITY AND THE PERCEPTION OF THE PAST. Jimena Biga

FOUR SPECIES OF SPANISH PATRIOTIC SONGS OF THE SPANISH WAR OF INDEPENDENCE 1808-1814. Aleksi Jari Ilmari Haukka

LA IDENTIDAD NACIONAL DEL PARTIDO COMUNISTA CHINO EN 1949: UNA APROXIMACIÓN A TRAVÉS DEL ANÁLISIS DE IMÁGENES. Ignacio Robba Toribio 


\section{TOMO 4}

\section{ARTES Y LENGUAJES}

COORDINADORES: MÓNICA KIRCHHEIMER Y GUSTAVO APREA

EL ESTUDIO DE LAS TRANSPOSICIONES DE LA LITERATURA AL CINE: LOS APORTES QUE DISTINTAS VERIENTES SEMIÓTICAS EFECTUARON AL CAMPO. María Rosa Del Coto

INTRODUCCIÓN FÍLMICO-LITERARIA DE VIAJES Y TRANSPOSICIÓN(ES). María Silvina Tatavitto

RETOMAS DEL CINE DE LOS 80: PROCEDIMIENTOS TRANSPOSITIVOS DE UN FENÓMENO PARTICULAR. José Tripodero

LA DESPEDIDA DE LOS AMANTES EN LA ESTACIÓN DE TREN. PERVIVENCIA Y MUTACIÓN DE FORMAS FÍLMICAS. Marina Locatelli

TEMPORALIDADES FICCIONALES - UNA EXPLORACIÓN DE LAS PARADOJAS TEMPORALES EN EL CINE DE FICCIÓN.

M. Laura Ragucci

POSIBLES PATHOSFORMELN EN LA HISTORIA DEL CINE. Mabel Tassara

CONFIGURACIONES DEL CINE REGIONAL EN LA PRENSA DE LA NORPATAGONIA DE LOS AÑOS OCHENTA. Ignacio Dobree

TUNCHES, PISHTACOS Y JARJACHAS: FORMAS ENUNCIATIVAS DEL MIEDO EN EL CINE REGIONAL ANDINO PERUANO. Miguel Ángel Torres Vitolas

LE CINÉMA ET SON DOUBLE OU LE PRINCIPE DE L'ASYNCHRONISME REVISITÉ. Ivan Capeller

WHAT'S IN THE NAME LIVE CINEMA? Marga van Mechelen 
TRÂNSITO E COMPLEXIDADES SENSORIAIS EM IMAGENS COMTEMPORÂNEAS. Lívia Machado

OPERACIONES DE LUDICIDAD Y AUTORREFERENCIA EN DOS CASOS DE ANIMACIÓN DIGITAL CONTEMPORÁNEA.

Maria Alejandra Alonso

SI SOLO SI: LA DISCAPACIDAD EN LA FICCIÓN TELEVISIVA ARGENTINA. Carolina Casali

CASI UNA SERIE. APUNTES TRASNOCHADOS SOBRE REALISMO Y CINE EN DOS MINISERIES MISIONERAS. Mauro Figueredo

TÉLÉVISION ET JUSTICE : UNE TRAJECTOIRE MÉDIATIQUE CONTROVERSÉE? Yannick Lebtahi

FORMAS DE VIDA MIGRATORIAS: ARTE E INTIMIDAD. Jaime Cordero

LO LÚDICO, LO SOCIAL Y LO POLÍTICO EN DOS CASOS DE ANIMACIÓN CONTEMPORÁNEA. Mónica Kirchheimer

SNUFF 2.0: SOBRE LOS VIDEOS DE VIOLENCIA Y MUERTE EN REDES SOCIALES. Julián Tonelli

DISPOSITIVOS Y ENUNCIACIÓN EN LA POSTFOTOGRAFÍA: ALGUNAS TRAYECTORIAS DE LA IMAGEN FOTOGRÁFICA DIGITAL EN REDES SOCIALES. Mariano Zelcer

LA AUTOPOIESIS DEL ACONTECER ARTÍSTICO QUE EMERGE A TRAVÉS DEL DIÁLOGO ENTRE DIFERENTES DIMENSIONES DE LA CORPORALIDAD. Daniela Lieban

TRASUNTO \#1: POESÍA EN TRÁNSITO. Valentina Paillaleve

LECTURAS DEL BIOARTE EN CLAVE SEMIÓTICA: AVANCES DE INVESTIGACIÓN. Lucía Stubrin

LA INTIMIDAD COMO APUESTA POLÍTICA EN RECORDAR 30 AÑOS PARA VIVIR 65 MINUTOS, DE MARINA OTERO. Luciana Estevez

DANZA EN PRIMERA PERSONA. EL GIRO AUTOBIOGRÁFICO EN LAS OBRAS DEL UNDER PORTEÑO. María José Rubin

HISTORIA, MONTAJE, ARCHIVO: PARA UNA PERFORMATIVIDAD DE LA MEMORIA. Cecilia Tosoratti 
INNOVACIONES DISCURSIVAS Y NUEVAS ESTÉTICAS DE LA HISTORIETA ARGENTINA CONTEMPORÁNEA.

Andrea Acosta Camargo, Laura Amarilla y Gaspar Buono

PIERRE DUPRAS, BÉDÉISTE CARICATURISTE ENGAGÉ.

Mila Falardeau

TRAYECTORIAS DE LA ABYECCIÓN EN EL ARTE POSMODERNO. Amparo Latorre Romero

UN NO LUGAR PARA LA FOTOGRAFIA: SOBRE LA SERIE ARCHIVO UTOPIA- EL PROYECTO BRASILIA. Vanesa Magnetto

EL GESTO MUSICAL Y LA COGNICIÓN CORPOREIZADA:

ARTICULADORES DEL SENTIDO EN LA DISCURSIVIDAD MUSICAL. Federico Buján

THE BODY AS MEDIUM: THE SUBVERSIVE SELF-PORTRAITSOF FRANCESCA WOODMAN. Patrícia Fonseca Fanaya

LA CONSTRUCCIÓN DEL TANGO COMO GÉNERO MUSICAL EN LOS MEDIOS MASIVOS. Jimena Jauregui

CUERPOS Y PALABRAS EN EL RITMO: LA ESCENA DE LA VOZ EN EL RAP FREESTYLE. Amparo Rocha Alonso

PROCEDIMENTOS RETÓRICOS E SEMIÓTICOS NA CANÇÃO RETRATO EM BRANCO E PRETO, DE CHICO BUARQUE E TOM JOBIM. Robson Costa Bessa y Alfredo Werney Lima Torres

MÚSICA Y PRODUCCIÓN DE SENTIDO EN EL CINE DE WOODY ALLEN. LA PRESENCIA DE OBRAS MUSICALES REPRESENTATIVAS DE UN DETERMINADO MOMENTO COMO REENVÍO A MANIFESTACIONES CULTURALES DEL PASADO. Carolina Inés Rochi

LA CADENA SIGNIFICANTE DE LOS CUERPOS EN LOS BOMARZOS ARGENTINOS. Jerónimo Brignone

VILLA-LOBOS: SYMBOLICAL AND SEMIOTICAL. Cleisson Melo 


\section{TOMO 5}

\section{COMUNICACIÓN MEDIÁTICA, PUBLICIDAD Y DIGITALIDADES}

COORDINADORES: MABEL TASSARA Y ROLANDO MARTÍNEZ MENDOZA

LA IMPORTANCIA DE LOS ESTUDIOS SEMIÓTICOS EN EL DISEÑO DE INTERFACES INTERACTIVAS. Francisco V. C. Ficarra

THE READING CONTRACT FOR THE CUSTOMIZATION ALGORITHM. Gustavo Markier

THE LAWS OF SEMIOTICS AND DIGITALIZATION OF CULTURE: THE BIRTH OF THE NEW MEANINGS. Marina Merkulova

MEMÓRIA E ESQUECIMENTO: AMBIVALÊNCIAS DO DIGITAL ENTRE A WIKILEAKS E O FACEBOOK. Francisco Rui Cádima

ZONAS DE CONTACTO Y LAS NUEVAS FORMAS DE CIRCULACIÓN: TRAYECTORIAS DISCURSIVAS Y PARTICIPACIÓN EN LÍNEA. Eduardo Ruedell y Viviane Borelli

SEMIÓTICA DAS INTERAÇÕES NO AUDIOVISUAL: PRODUÇÃO DE SENTIDOS NO CLIPE INTERATIVO "SATURN BARZ".

Bárbara Heliadora Cavalcante Fontenelle y Murilo Scoz

ARI FOLMAN'S PROMISES OF TECHNOLOGICAL MEDIATION IN THE CONGRESS. Cassia Cassitas

A TRANSMÍDIA COMO SEMIOSFERA PARA A CONSTRUÇÃO ESTÉTICA. Gisele Frederico

CONFIGURACIONES DISCURSIVAS DE LA CRÍTICA CINEMATOGRÁFICA EN YOUTUBE. Laura Andrea Iribarren

FOLKLORE DIGITAL, PROSUMIDORES Y CREEPYPASTA. Sandra Sánchez 
SEMIÓTICA NARRATIVA EN EL DISCURSO PUBLICITARIO CONTEMPORÁNEO: ANÁLISIS DE LA LANDING PAGE DE "MANANTIALES" DEL GRUPO EDISUR. Belén Angelelli y Natalia Desirée Vaccaro

SMARTHPHONES Y AURICULARES PARA INSCRIBIR LA CIUDAD COMO ESCENOGRAFÍA. Mónica Berman

REFLECTIONS ABOUT NEW PERCEPTIONS ON SPACE AND TIME: THE USE OF MOBILE PHONE IN THE METRO DE SANTIAGO, CHILE. Catalina Largo González

SEMIÓTICA APLICADA: CAMPANHA PUBLICITÁRIA JOURNEY, COM ANGELINA JOLIE, SOB O ESPECTRO DA TEORIA PEIRCEANA.

Carolina Boari Caraciola

MODALIDADES DE INSERCIÓN DE EMERGENTES CULTURALES EN LA COMUNICACIÓN DE LAS MARCAS. Claudio Centocchi

LA CONSTRUCCIÓN DEL DESTINATARIO EN LA MARCA PAÍS ARGENTINA. Daniela Fiorini y Paula Socolovsky

SEMIÓTICA APLICADA: ANÁLISE DE PEÇAS DA MARCA GATORADE À LUZ DA TEORIA PEIRCEANA. Gabriel Moni de Souza, Heder SeitiOno y Maria Clotilde Perez

TRAJECTORIES AND MEANINGS IN SPECIALTY COFFEE PACKAGING: A SEMIOTIC EXPLORATION OF THE BRAZILIAN MARKET. Maria Collier de Mendonça, Flavia Cardoso y Richard Perassi

ESTRATEGIAS, TRANSACCIONES Y SÍMBOLOS EN LA PUBLICIDAD ELECTORAL AUDIOVISUAL. María Ernestina Morales

RACISMO Y CLASISMO EN LA PUBLICIDAD MEXICANA. Carl Winston Jones

ADVERFILMS Y FENÓMENOS DE RETOMA: UNA APROXIMACIÓN SOCIOSEMIÓTICA A LA DISCURSIVIDAD PUBLICITARIA EN PLATAFORMAS INTERACTIVAS. Lorena Steinberg 


\section{TOMO 6}

\section{ESPACIALIDADES Y RITUALIZACIONES}

COORDINADOR: JOSÉ LUIS CAIVANO

POETIC SYMBOLS OF UNLIMITED TIME. Richard Trim

FUNDAMENTOS SEMIÓTICOS, ONTOLÓGICOS Y COGNITIVOS PARA UNA TEORÍA SEMIÓTICA DEL ESPACIO GEOGRÁFICO: APORTES DE UNA TESIS DOCTORAL. Emilas Darlene Carmen Lebus

SIGNIFICACIONES Y ACCIÓN SEMIOTÉCNICA EN LOS PROCESOS PRODUCTIVOS AGRARIOS DEL NORDESTE SANTAFESINO EN EL ESCENARIO DEL NORTE GRANDE ARGENTINO. TENDENCIAS Y CONTEXTOS DE SENTIDO. Emilas Darlene Carmen Lebus

DISCURSO JURÍDICO DE LA PLANEACIÓN DEL TERRITORIO EN COLOMBIA. ANÁLISIS SEMIO-DISCURSIVO: ESTUDIO DE CASO. Lucila Reyes Sarmiento y Camilo Alejandro Rodríguez Flechas

APUESTA ANALITICO TRANSDISCIPLINARIA FRENTE A LA HIBRIDACIÓN DE LAS AMENAZAS EN LA FRONTERA COLOMBOECUATORIANA EN CLAVE PROSPECTIVA. María Fernanda Noboa González

EL SUELO ES LAVA: REPRESENTACIÓN DE LOS FENÓMENOS VOLCÁNICOS EN RELATOS AUDIOVISUALES. Ignacio Dobrée y Ailén Spera

"SANTANDER AYER Y HOY, MEMORIAS DEL PATRIMONIO", UNA EXPERIENCIA CROSSMEDIA DEL ENTORNO FÍSICO AL DIGITAL. Norberto Fabián Díaz Duarte y Carolina Raigosa Díaz

EL ACTO DE LA REPRESENTACIÓN VISUAL MUSEAL COMO PUENTE ENTRE EL CONOCIMIENTO SOCIOLÓGICO Y EL SOPORTE SEMIÓTICO. Sebastián Chávez Hernández

APROXIMACIÓN AL CAMPO DE INTERTEXTOS EN LA OBRA DE TOMÁS SARACENO. María Rosa More 
LAS CULTURAS DE LOS PIXADORES Y DE LOS ESCRITORES DE GRAFFITI. Marco Tulio Pedroza Amarillas

MAPAS, CIDADES, MUROS: IMPRESSÕES DO/NO ESPAÇO. Kati Caetano y Adriana Tulio Baggio

CULTURAL LANDSCAPE AS METAPHOR. Olga Lavrenova

A SEMIOTIC JOURNEY THROUGH THE CONCEPT OF TRAJECTORY IN LATOUR'S THEORY. Giacomo Festi

TRANSCULTURALIDAD E IDENTIDAD EN LA MESOAMÉRICA CONTEMPORÁNEA. Horacio Mendizábal García

A SEMIOTIC AND GEOGRAPHICAL APPROACH TO MONUMENTS AN ANALYSIS OF THE MULTIPLE MEANINGS OF MONUMENTS IN TALLINN, ESTONIA. Federico Bellentani

SPACE, POWER AND INTER-SEMIOTIC TRANSLATION: THE SYMBOLISM OF ROME AND THE FASCIST REGIME. Pierluigi Cervelli

LA ITINERANCIA PÚBLICA Y EFIMERA COMO MODELO DE REPRESENTACION POPULAR Y POTENCIADORA EN LA PERFORMANCE CULTURAL Y POLITICA DE LOS FESTEJOS DEL BICENTENARIO. Daniela Lieban

LA SEMIÓTICA DE LOS HIMNOS PATRIOS Y SU INCIDENCIA EN LA CONFIGURACIÓN DE LA MENTALIDAD COLECTIVA. Julio César Rivera Dávalos

LA NOSTALGIA DEL SEXO FELIZ O REFLEXIONES SOBRE LA NOCHE DE LA NOSTALGIA EN URUGUAY. Claudia Mera Rodríguez

LA SANTIDAD COMO UNA FORMA DE VIDA Y LA FIGURA DE SANTA GIANNA BERETTA MOLLA. Jenny Ponzo

JAMES THE APOSTLE ICON: TRAJECTORIES IN HISPANIC LITERATURE (12TH-16TH CENTURIES). Lidia Raquel Miranda

SEMIOTIC INTERPRETATIONS OF THE SQUARE AND THE CIRCLE IN RELIGIOUS CULTURAL HERITAGE. Hee Sook Lee-Niinoja

SEMIOTICS AND AESTHETICS AS A DISCOURSE ON ARCHITECTURE CASE STUDY: MINIMALISM IN ARCHITECTURE. Dragana Vasilski 
INTER-SEMIOTIC APPROACH TO TEXTS-IMAGES OF FOOD SEALER ZIPPER BAGS. Hee Sook Lee-Niinioja

THE ESTHESIC TRANSFORMATION OF THE BUBBLE TEA: FROM EAST TO WEST. Rafael G. Lenzi

AT THE CROSSROAD OF BIOSIMULATION AND DESIGN: NOVEL CODES IN BI-MODAL REPRESENTATION OF BLOOD FLOW. Dolores A. Steinman y David A. Steinman 


\section{TOMO 7}

\section{PALABRAS PÚBLICAS}

COORDINADORES: MARIA ALEJANDRA ALONSO Y SERGIO RAMOS

LLORANDO EN EL COLÓN. RETOMAS DISCURSIVAS DEL G-20 EN LOS INTERNET MEMES. Nicolás Canedo, Verónica Urbanitsch y Daniel Sierra

SEMIÓTICA Y NARRATIVAS POLÍTICAS: PERSUASIÓN Y PROPAGANDA EN LA CONFIGURACIÓN DISCURSIVA DE LA IDENTIDAD DE ACTORES POLÍTICOS DEL CHACO A TRAVÉS DE LOS MEDIOS DE COMUNICACIÓN DE MASAS. Natalia Virgina Colombo y Romina Gisel Gayoso

LA DIMENSIÓN POLÉMICO/ANTAGÓNICA DEL DISCURSO PERONISTA. LA POLÉMICA PERÓN/LANUSSE. Hugo José Amable

VERIDICÇÃO E DISCURSO: INFORMAÇÃO E DESINFORMAÇÃO NO "JOGO DA VERDADE" DAS AGÊNCIAS DE CHECAGEM DE FATOS (FACT-CHECKING). Simone Bueno da Silva y Valdenise Leziér Martyniuk

¿GOLPE O IMPEACHMENT? LA POLARIZACION MEDIA DE LAS REVISTAS VEJA Y CARTA CAPITAL. Hélen Rodrigues Simões

JORNAIS REGIONAIS E A CONSTRUÇÃO DE VÍNCULOS COM SEUS LEITORES. Fabiana Sparremberger y Viviane Borelli

LA REVISTA TÍA VICENTA COMO EXPERIENCIA SEMIÓTICA CRÍTICA QUE DESVELA UNA REALIDAD POLÍTICA Y SOCIAL. María Lourdes Gasillón

EL ENCIERRO COMO ESPACIO NARRADO. Valeria Vivas Arce

LA SEMIÓTICA DEL ESPACIO POLÍTICO: UN ESTUDIO DE CASO EN AMÉRICA HISPANA TARDO-COLONIAL. Carmen Susana Cantera

AÇÃO COLETIVA E GERAÇÃO DE SENTIDO: OS DESAFIOS DE GESTÃO DE UM ESPAÇO PÚBLICO EM CRISE. Karin Vecchiatti 
TERRITORIOS EDUCATIVOS: LA LECTURA Y LA ESCRITURA EN LOS UMBRALES. Carla Vanina Andruskevicz

MANIOBRAS Y OPERACIONES SEMIÓTICAS EN LOS UMBRALES DE LA ALFABETIZACIÓN INICIAL. REFLEXIONES ACERCA DE PRÁCTICAS Y RELATOS EN LA FRONTERA. Raquel Alarcón y Froilán Fernández

APROXIMACIÓN DESDE LA SEMIÓTICA VISUAL EN EL DISEÑO DE MATERIALES DIDÁCTICOS PARA SORDOS. Lucero Fabiola García Franco

JÓVENES QUE CUENTAN: ANÁLISIS DE RELATOS AUDIOVISUALES DE ESTUDIANTES DE SECUNDARIOS. Corina Ilardo

EL GÉNERO AUDIOVISUAL ESCOLAR. CONTINUIDADES EN EL ANÁLISIS DE PRODUCCIONES PERIFÉRICAS Y PROPUESTA TEÓRICOMETODOLÓGICA. Diego Agustín Moreiras

COMPARATIVE ANALYSIS OF THE STATE OF AFFAIRS IN THE FIELD OF ART SEMIOTICS: SEMIOTICS OF VISUAL, AUDIOVISUAL AND PERFORMANCE LANGUAGES BETWEEN THE NATIONAL UNIVERSITY OF CORDOBA, ARGENTINA AND THE INSTITUTE OF ROMANCE LANGUAGES AND CULTURES, UNIVERSITY OF POTSDAM, GERMANY. Fabiola C. de la Precilla

ALFABETIZACIÓN SEMIÓTICA EN LA UNIVERSIDAD: DEVENIRES DE LA ENSEÑANZA DE LA SEMIÓTICA EN LAS CARRERAS DE LETRAS DE LA FACULTAD DE HUMANIDADES DE LA UNNE. Natalia Virginia Colombo

ENSEÑANZA DE LA SEMIÓTICA APLICADA A LA PLANIFICACIÓN DE PROYECTOS DE COMUNICACIÓN. EL DEVENIR DE UNA TRAYECTORIA ESPECÍFICA DE LA SEMIÓTICA ARGENTINA. Maria Alejandra Alonso, Rolando Martínez Mendoza y Sergio Ramos

DE QUÉ SIRVIÓ LA SEMIÓTICA. SEMIÓTICA APLICADA A LA PLANIFICACIÓN DE PROYECTOS DE COMUNICACIÓN EN UN ENTORNO VIRTUAL DE ENSEÑANZA Y APRENDIZAJE. Maria Alejandra Alonso y Sergio Ramos

LA HETEROGENEIDAD EN LA COMUNICACIÓN CIENTÍFICA. UN ANÁLISIS DISCURSIVO DESDE LA SEMIÓTICA DE LA CULTURA. Carina Itzel Gálvez García 


\section{TOMO 8}

\section{CONFERENCIAS PLENARIAS}

COORDINADORES: OSCAR STEIMBERG, OSCAR TRAVERSA Y

GASTÓN CINGOLANI

PAOLO FABBRI (1939-...). Tiziana Migliore

(traducción al español Claudio Guerri)

METALOGUES MEET INTERVIEW: IT TAKES THREE TO TANGO. Myrdene Anderson

MATRICES IDEOLÓGICAS Y COMPONENTE RETÓRICO EN LA DISCURSIVIDAD POLIITICA: LAS EMOCIONES EN MAURICIO MACRI Y CRISTINA FERNÁNDEZ DE KIRCHNER, AGOSTO DE 2019. Elvira Narvaja de Arnoux

A GRADUALIST PERSPECTIVE FOR A SEMIOTIC APPROACH TO VISUAL IMAGES. José Luis Caivano

TRAYECTORIA Y CONTINUIDAD DE LA TEORÍA TEXTUAL DE UMBERTO ECO EN LAS NUEVAS NARRATIVAS Y SUS ESTRATEGIAS TEXTUALES. Alfredo Tenoch Cid Jurado

LUIS PRIETO. LA RECUPERACIÓN DE UNA TEORÍA MUY PERTINENTE. María Teresa Dalmasso

EPISTEMOLOGÍA PARA UNA SEMIÓTICA DEL ESPACIO: CÉSAR JANNELLO. Lucrecia Escudero Chauvel

CURSOS SEMIÓTICOS: CAMINOS Y TRAYECTORIAS ANTRÓPICAS. Jacques Fontanille

APPLYING PEIRCE. FROM THE THREE CATEGORIES TO THE SEMIOTIC NONAGON. Claudio F. Guerri

TRAJECTOIRES DE LA SÉMIO-LINGUISTIQUE. Anne Hénault

A NON-ANTHROPOCENTRIC SEMIOTICS OF THE WRITING IN THE ERA OF THE POSTHUMAN LITERACY. Sung do Kim 
¿POR QUÉ HAY SENTIDO Y NO MÁS BIEN NADA? EXPERIENCIA, COGNICIÓN, SENTIDO. Jean-Marie Klinkenberg

PRESENTACIÓN DEL PROYECTO SEMIÓTICO: ACTUALIDAD DE RENÉ THOM. Isabel Marcos

THE SEMIOTIC METHOD. Tiziana Migliore

TRAJECTORIES OF MEANING IN SPACE AND VALUE SYSTEMS. Pierre Pellegrino

TRANSDISCIPLINARY TRAJECTORIES: THE AUDACITY OF DESIGN AND THE RESILENCE OF SIGNS. Farouk Y. Seif

READING TRAJECTORIES AND SEMIOSIS, GRAPHIC DESIGN AND IDEOLOGY. Evripides Zantides

SEMIÓTICA DE UN PROCESO UTÓPICO Y OTRO DISTÓPICO EN AMÉRICA LATINA: DOS SENDEROS ANTITÉTICOS HACIA LA AUTENTICIDAD. Fernando Andacht

TERRITORIOS ARTÍSTICOS EN DISPUTA. LA OBRA DE EDUARDO KAC. Pampa Arán

SEMIOSIS OF THE BODY IN ARAB SEXOLOGICAL LITERATURE. Mohamed Bernoussi

TRAYECTORIA DE LA SEMIÓTICA DE LAS MEDIATIZACIONES HACIA LAS PLATAFORMAS MEDIÁTICAS. José Luis Fernández

LE WEB 2.0 : UNE NOUVELLE TRAJECTOIRE POUR LA SÉMIOLOGIE AUDIOVISUELLE? François Jost

VECINDADES DIGITALES. HACIA QUÉ OBJETOS APUNTAN LOS ÍNDICES. María del Valle Ledesma

ROSTROS GIGANTES: TAMAÑO VERSUS PROPORCIÓN EN LA SEMIÓTICA DEL PODER. Massimo Leone

SEMIOSIS DE LAS ARTES PERFORMATIVAS: A PARTIR DEL CUERPO DE LAS ENVOLTURAS. Rocco Mangieri

DEL ESPACIO A LA CIUDAD. TRAYECTORIAS SEMIÓTICAS. Isabella Pezzini 
PRESENCIA, IDENTIDAD Y AFECTIVIDAD EN LOS HERALDOS NEGROS, DE CÉSAR VALLEJO. APUNTES DE HERMENÉUTICA SEMIÓTICA.

Óscar Quezada Macchiavello

CONTINUIDADES Y RUPTURAS EN LA NARRATIVA DE LA HISTORIETA COSTUMBRISTA. Oscar Steimberg

SALOMÉ Y JUDIT: DOS MILENIOS DE RECURRENCIA DISCURSIVA. Oscar Traversa

LOS LUGARES DE LA MEMORIA EN UN MARCO SEMIÓTICO. LA EXPERIENCIA DE SPEME. Patrizia Violi

FROM BUFFY TO A DISCOVERY OF WITHCHES. SEMIOTIC CONSIDRATIONS ON VAMPIRES, WITCHES, AND PRETERNATURAL PHENOMENA IN LITERATURE AND TELVISION. Gloria Withalm 
है।

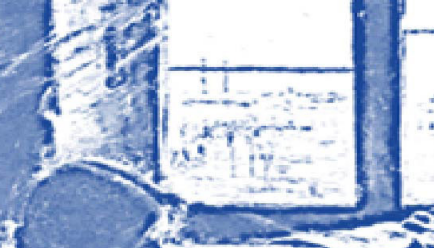

$e^{10}$

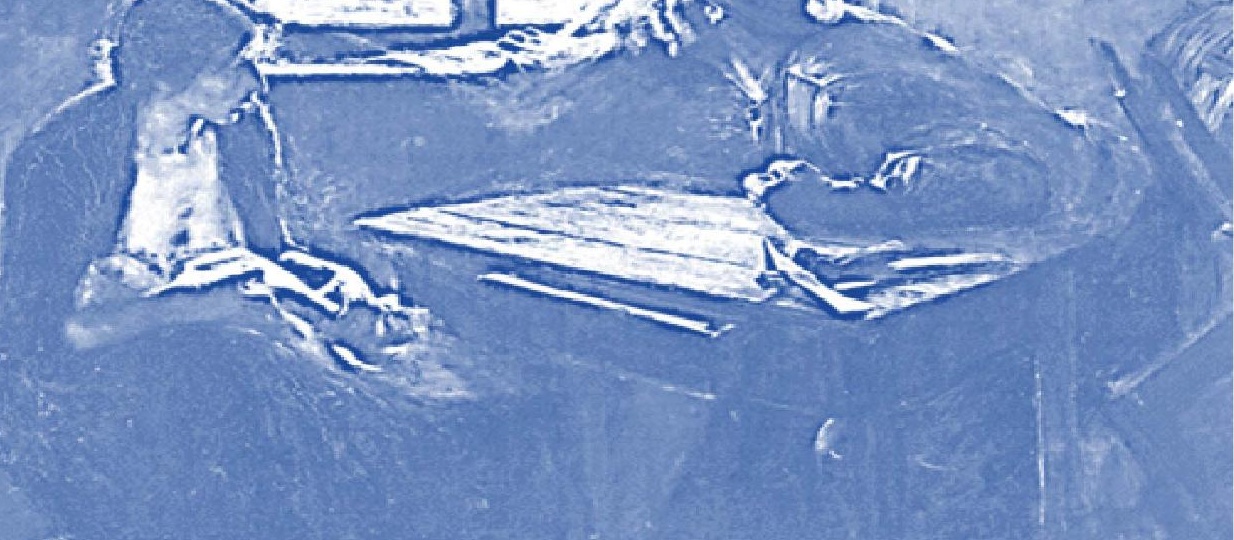

the

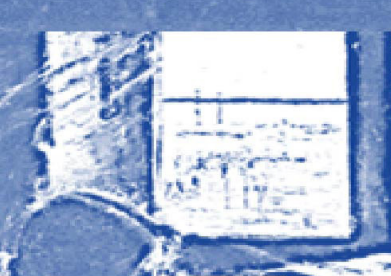

$\int_{10}^{10}$

1.

(a)

$+$

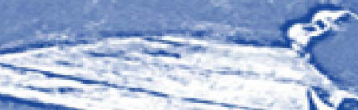

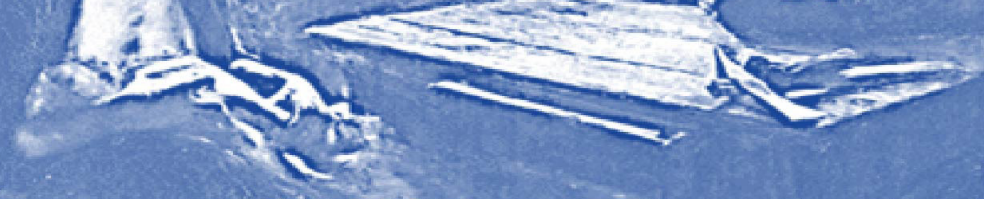

C.

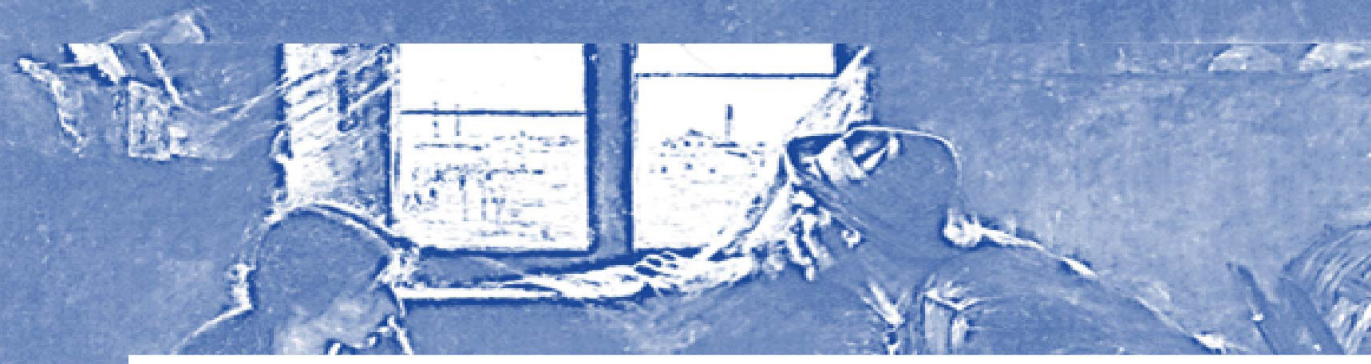

\section{(AAS ASOCIACIÓN ARGENTINA UE SEMIÓTICA}

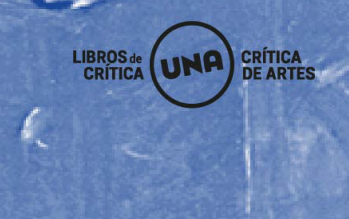

